\title{
LOW-Lying STATES, ClimATE CHANGE-INDUCED RELOCATION, AND THE COLLECTIVE RIGHT TO SELF-DETERMINATION
}

\author{
BY \\ NATHAN JON ROSS
}

A thesis

submitted to the Victoria University of Wellington

in fulfilment of the requirements for the degree of

Doctor of Philosophy in Law

Faculty of Law

TE WHARE WĀNANGA O TE ŪPOKO O TE IKA A MĀUI

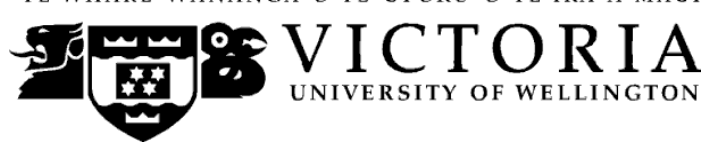

2019 



\section{Abstract}

It is increasingly likely that, due to the impacts of climate change, entire populations of low-lying States - Tuvalu, Kiribati, the Marshall Islands and the Maldives - will need to relocate to other States' territories. Such en masse relocations would jeopardise these peoples' national identities and manifestations of their ways of life: cultures, languages, customs, and social, political and economic systems.

Legal writers analysing this topic focus mainly on maritime boundaries and statehood questions. This thesis examines the right to self-determination. The principal finding is that the peoples of low-lying States are entitled to enjoy self-determination in climate change-related relocation and that there are practical ways this can occur.

After explaining the factual scenario and the approach to this research, the analysis has four key components. First, it defines the right to self-determination in context of the low-lying States, including entitlements flowing from this collective right. The populations of low-lying States' are "peoples" entitled to self-determination, including in relocation. Self-determination comprises various elements, resembling a bundle of rights. A framework is devised for unpacking this bundle and understanding what self-determination entails. The framework divides the right into strategic and operational elements. The strategic elements are the right's objectives of peace and human rights, as well as its classic expressions; external and internal self-determination. The operational elements seek to secure the right's objectives through substantive and procedural entitlements. Substantive entitlements include the right of peoples to continuity of their States, to be different, to freely-determined political statuses, and to freely-pursued economic, social and cultural development. Procedural aspects include processes for determining the substantive elements, plus democratic governance, and some degree of autonomy from other political units.

The second major component of this thesis examines potential duty-bearers, and the nature of their duties. Low-lying States are the principal duty-bearers regarding their peoples' right to self-determination. Third-party States and the United Nations 
have relevant duties, but these are vague and do not anticipate proactive involvement in supporting low-lying peoples' endeavours to maintain self-determination ex situ. The duties become clearer for a third-party State that partners in a low-lying people's relocation, but there are no obligations to become such a partner.

The third part of the legal analysis re-examines the issue of whether statehood can be maintained without inhabitable territory, but in light of the self-determination analysis. There is a presumption of continuity of statehood in international law and it applies to low-lying States. There is no legal basis to argue that statehood would be terminated in this relocation scenario. The presumption of continuity is bolstered by self-determination, which gives the peoples of low-lying States exclusive competence to determine their political statuses. Prior analyses of statehood have focused on the Montevideo Convention indicia. However, these indicia only apply to the creation of States, not termination. Consequently, there is far-reaching flexibility for extant States to decide how, or whether, the indicia are satisfied.

Finally, options for enabling ex situ self-determination are presented concerning key questions of legal personality (since statehood is only one option), land and international frameworks. The final section also proposes ways of incorporating self-determination into the emerging human rights-based approach to climate change adaptation. 


\section{Acknowledgements}

Thanks to my family, Hilary Blake, Niamh Ireland-Blake and Maia IrelandBlake, who have supported me in many different ways through the $\mathrm{PhD}$ years, especially Hilary. Thanks and apologies in equal and generous measures.

Thanks to my supervisors, Alberto Costi and Joanna Mossop, for your expertise, insights and support. Thanks to Alberto also for finding practical ways to enable me to undertake this doctorate.

Thanks to the Victoria University of Wellington for the scholarship, the outstanding library resources, and many other forms of support.

Thanks to the many other people who have put their time, minds, hearts and resources into the many issues relevant to this thesis, all with the goal of helping make the world less challenging. 
Summary Contents

Chapter 1: Introduction, Problem Definition and Scope ........................................... 1

Chapter 2: The Meaning of Self-Determination in the Context of Low-lying Peoples' Relocation Enterprises...............................................................33

Chapter 3: Duty-Bearers and Potential Obstacles to Low-Lying Peoples' Ex Situ Self-Determination......................................................................93

Chapter 4: Statehood Continuity …...............................................................................127

Chapter 5: Options for Enabling Self-Determination ..........................................169

Chapter 6: Conclusion.........................................................................................................239

Bibliography ...........................................................................................................................247 


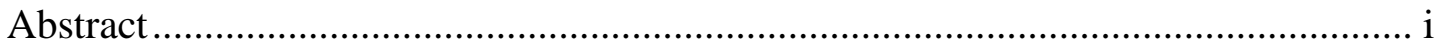

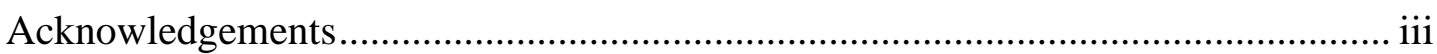

Summary Contents...................................................................................... iv

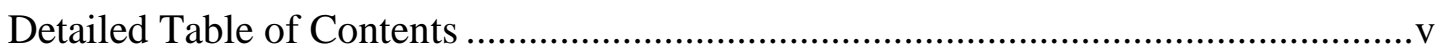

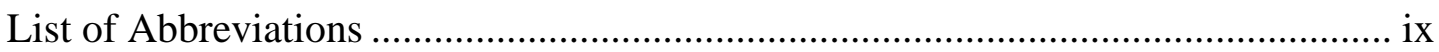

Chapter 1: Introduction, Problem Definition and Scope ...........................................1

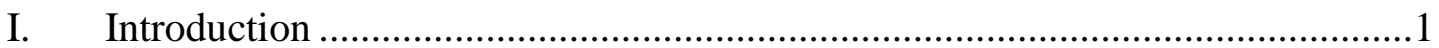

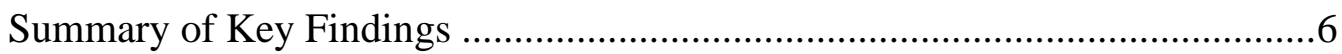

II. Problems for Low-lying States and their Peoples Caused by Climate Change...7

III. Problems Associated with En Masse Relocation ..............................................11

A. Risks in International Law: Self-Determination and Statehood ..............12

B. Impoverishment Risks with Planned Relocation, including a Proposal for

a New Risk Category .....................................................................13

C. Relocation Processes plus Associated Uncertainties ..............................19

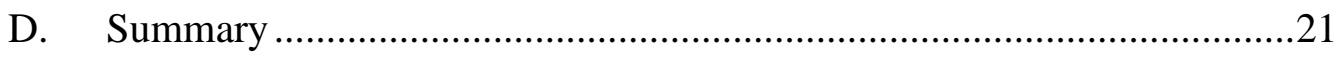

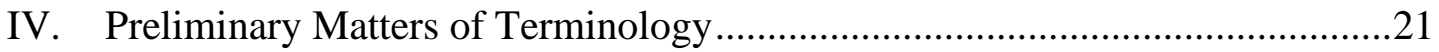

A. Migration, Relocation, Low-lying States, and Partner States ..................21

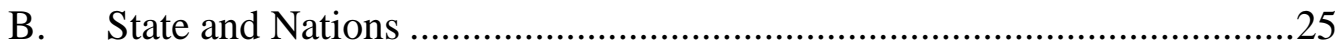

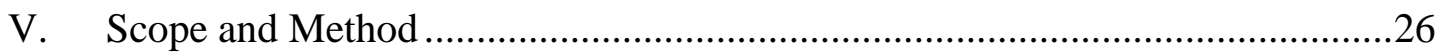

A. Research Scope and Questions ..........................................................26

B. Using International Law as Ex Ante Guidance for Low-Lying States' Relocation Enterprises .....................................................................28

VI. The Author's Subjective Context and Implications for Research Findings........30

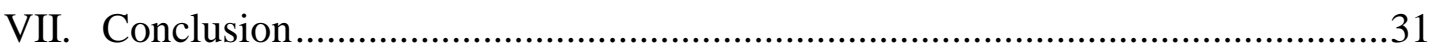

Chapter 2: The Meaning of Self-Determination in the Context of Low-lying Peoples' Relocation Enterprises ...........................................................33

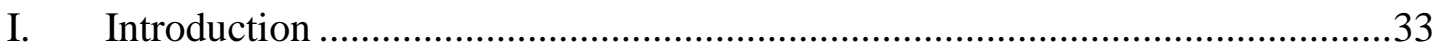

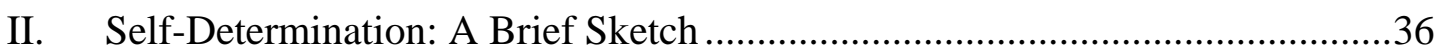

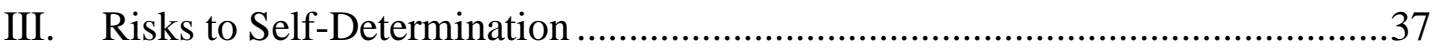

IV. The Ex Situ Continuity of the Right to Self-determination in Climate-Induced

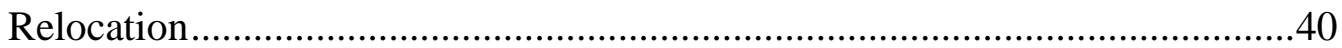

A. Rights-Holders: as a "People" or a "Minority" .......................................40

B. A Right beyond Decolonisation ........................................................48

1. The Right Belongs to a People, not a Territory....................................................49

2. The Right Belongs to a Peoples, not only in Decolonisation ...............................50

C. Concluding on Ex Situ Entitlement to Self-Determination ......................55

V. The Concurrent Emergence of Self-Determination as both Law and Duty ......56

A. The Emergence of a Duty of Assistance ...................................................56 
B. The Imprecise Implications of Self-Determination ..............................61

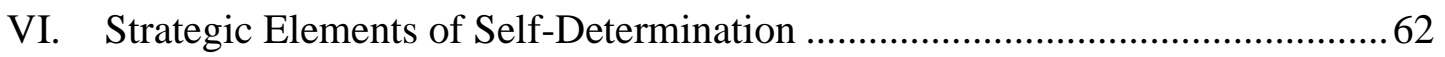

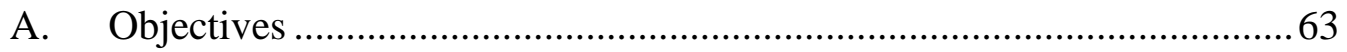

B. External and Internal Dimensions of Self-Determination ........................6 68

VII. Operational Elements of Self-Determination............................................... 72

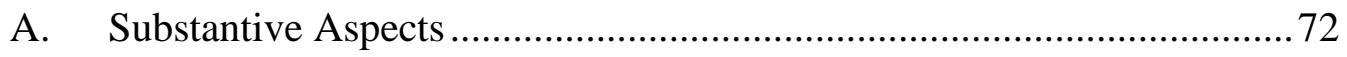

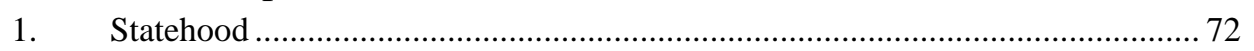

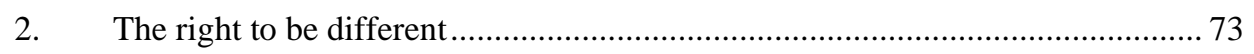

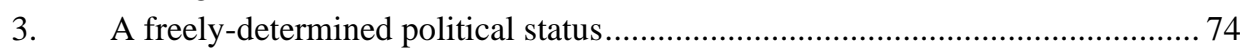

4. Economic, social and cultural development ………………………………..... 75

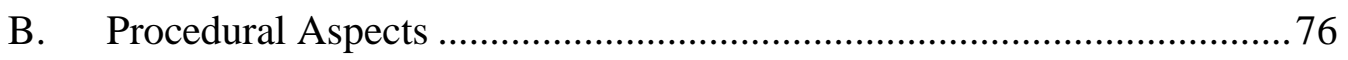

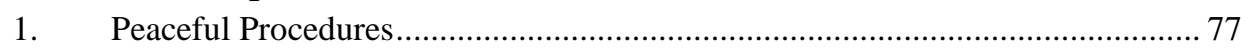

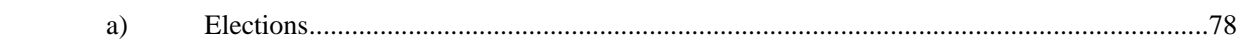

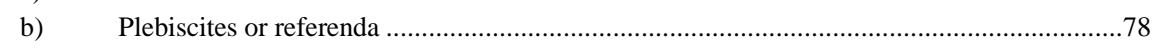

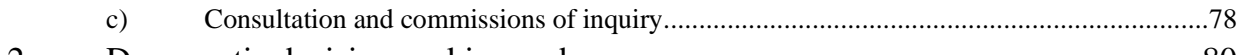

2. Democratic decision-making and governance ........................................ 80

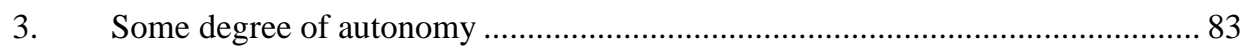

C. Concluding on Procedural and Substantive Aspects ..............................8 88

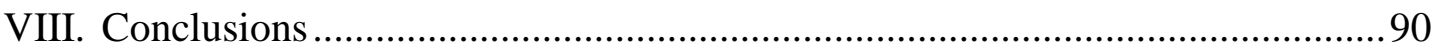

\section{Chapter 3: Duty-Bearers and Potential Obstacles to Low-Lying Peoples'}

Ex Situ Self-Determination................................................................93

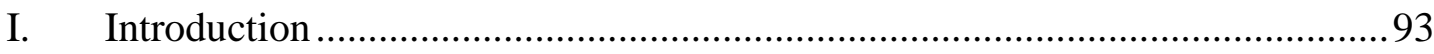

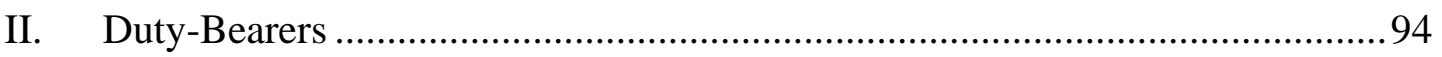

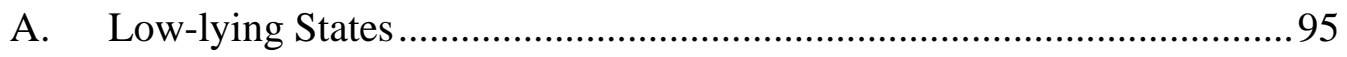

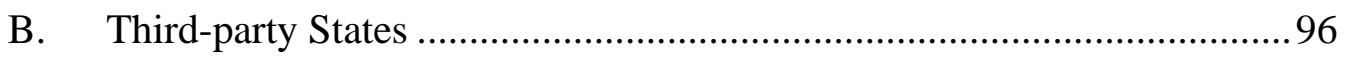

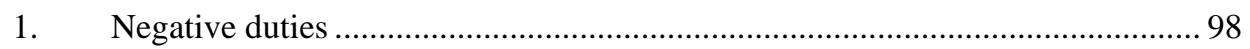

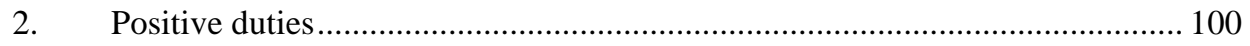

3. The potential for passive undermining of self-determination ........................... 101

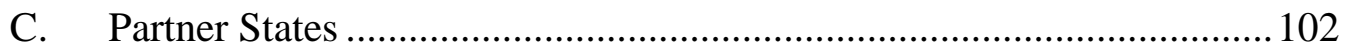

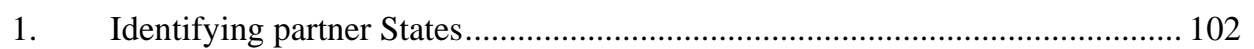

2. Functional Reasons for Why a State Might Volunteer to Become a Partner State.

3. Duties of partner States.................................................................................. 110

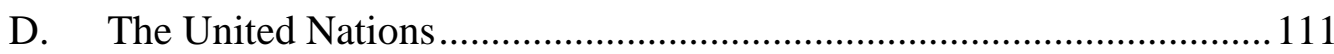

E. Summarising Rights-Holders and Duty-Bearers ................................. 114

III. Additional Guidance on Duties from Climate Change Law ........................... 115

IV. Potential Obstacles to Low-Lying States' Ex Situ Self-Determination............ 120

V. Concluding on and Synthesising All Self-Determination Elements ................ 124

Chapter 4: Statehood Continuity .......................................................................127

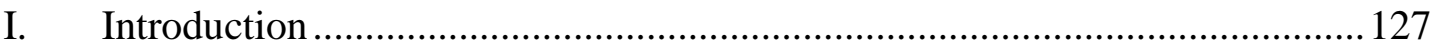

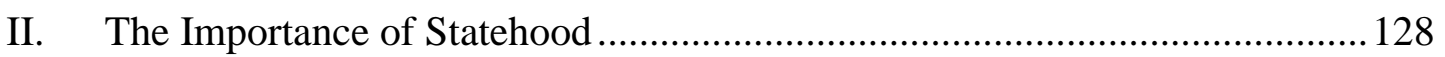

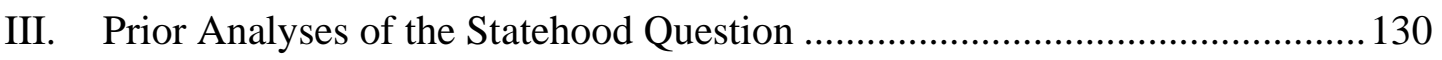

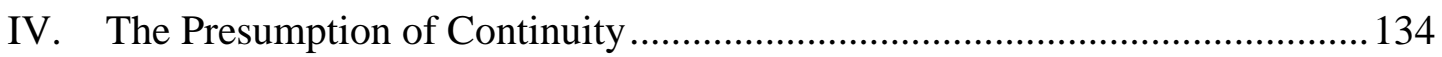


V. The Relationship between the Presumption of Continuity and the Right to Self-Determination

VI. The Relationship between the Presumption of Continuity and the Montevideo Indicia.

A. New States Only; Not Termination....................................................144

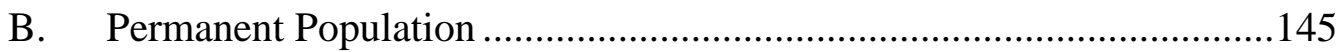

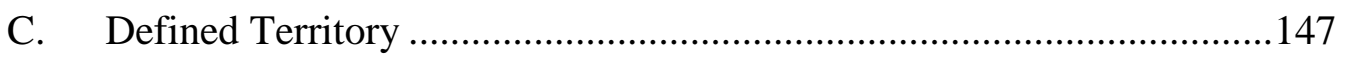

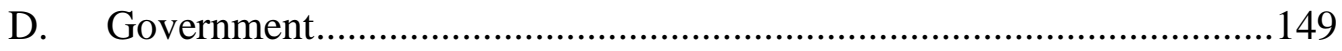

E. Capacity to Enter International Relations ............................................157

F. The Potential Role of Self-Determination in Bolstering Continuity where there is only Partial Satisfaction of the Montevideo Indicia..................159

G. Concluding on the Statehood Indicia .................................................161

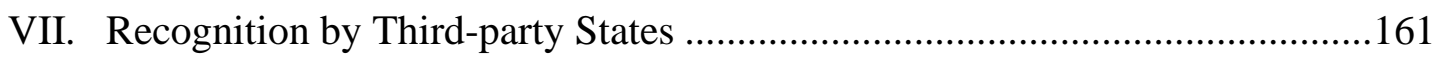

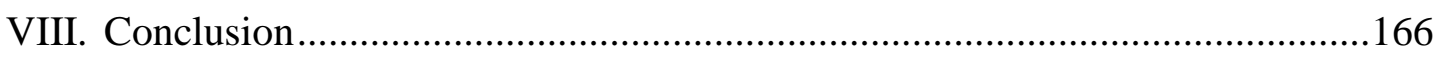

Chapter 5: Options for Enabling Self-Determination .....................................169

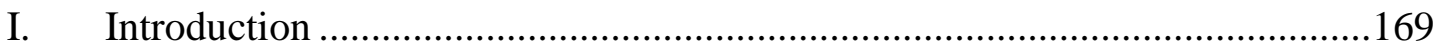

II. Legal Personality: International and Municipal Forms ................................172

A. A Sovereign and Independent State .................................................173

B. Free association or integration with another State ..............................174

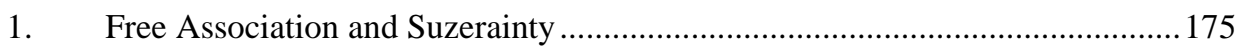

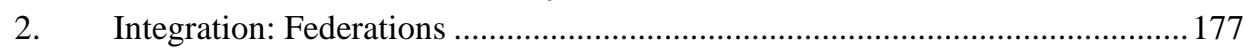

C. "Any other political status": Non-Self-Governing Territories and

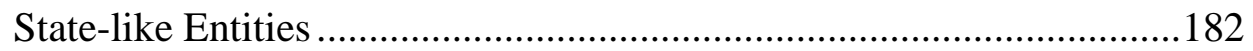

1. Non-Self-Governing Territories................................................................... 183

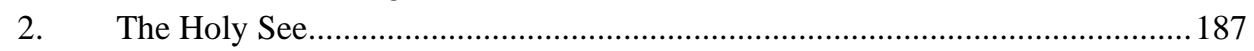

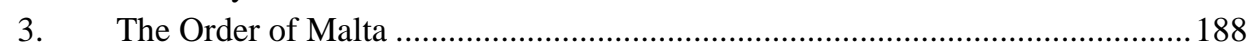

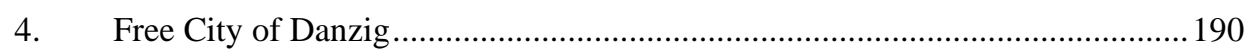

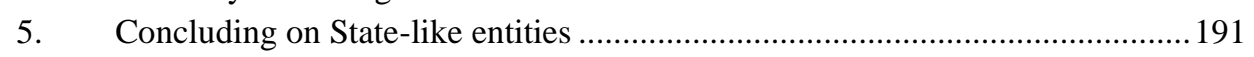

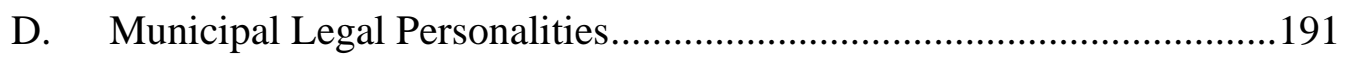

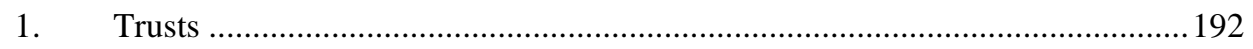

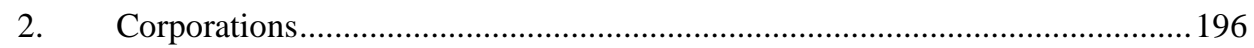

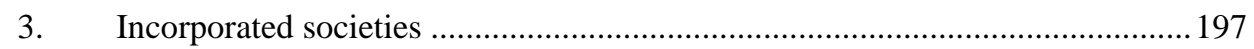

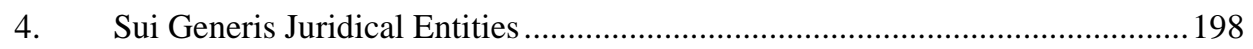

5. Concluding on Municipal Legal Personalities …………………...................... 198

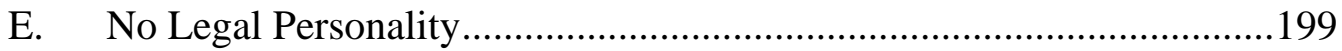

F. Concluding on Forms of Legal Person .................................................200

III. Land: Modes of Acquiring Land as Territory or Property ….........................200

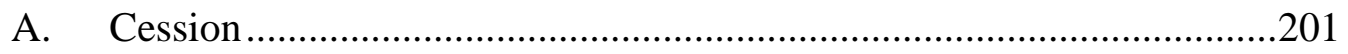

B. Condominium: Shared Sovereignty …............................................202

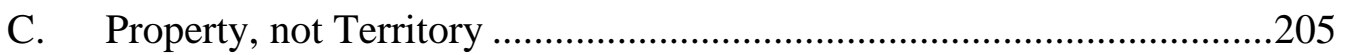

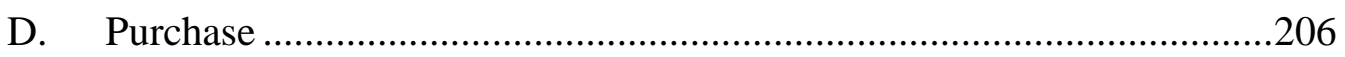

E. International and Quasi-international Leases....................................207

F. A Note on Geographic Arrangements: Enclaves and Exclaves .............208 
G. Will People Stay Together? Liberty of Movement and Diasporic Cosmopolitanism....

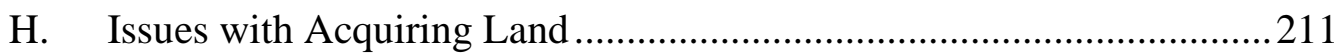

IV. International Frameworks for Enabling Ex Situ Self-Determination .............2212

A. Multilateral Agreements ...................................................................2214

B. Soft Law Instruments and Voluntary Cooperation Initiatives ...............217

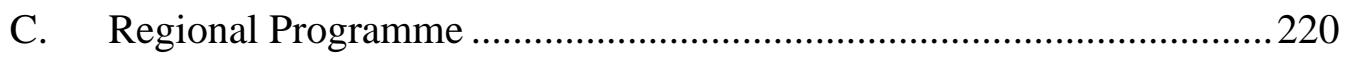

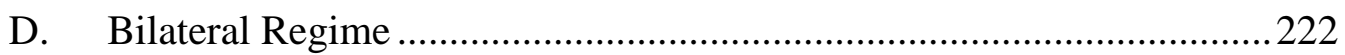

E. Reflecting on the Various Frameworks for Ex Situ Self-Determination

V. The Human Rights-Based Approach to Climate Change Policies and its Application to Low-Lying Peoples' Relocation and Self-Determination .......224

A. Background and Definition of the HRBA ….....................................225

B. Current Limitations for Self-Determination in the HRBA ....................226

C. Detailing Self-Determination in a HRBA to Climate-related Relocation 228

D. Concluding on the HRBA to Ex Situ Self-Determination.....................2231

VI. Discussion, including Hypotheticals to Illustrate how the Options can be Assembled for a Holistic Relocation Enterprise

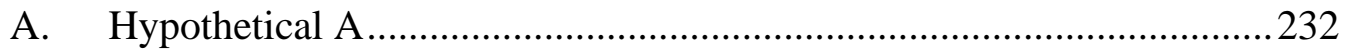

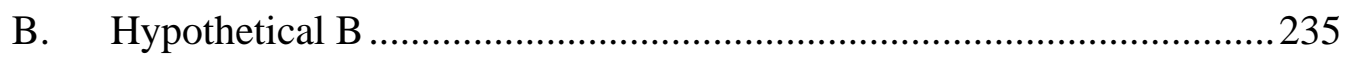

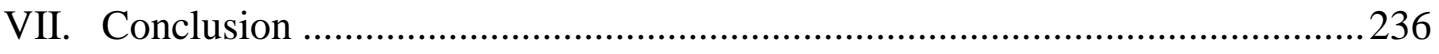

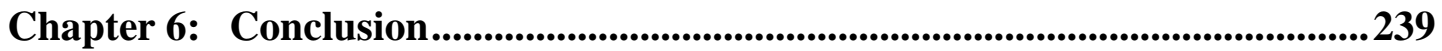

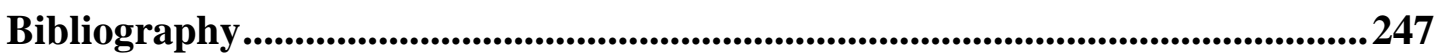

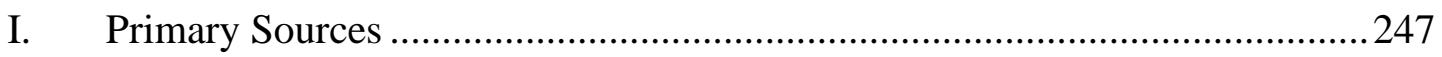

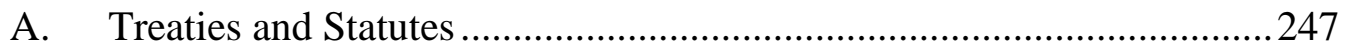

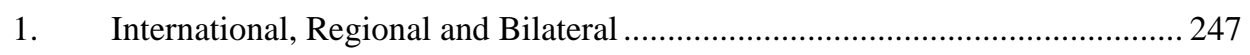

2. Domestic Jurisdictions................................................................................ 249

B. Cases (Courts, Arbitrations, and Investigations) ................................250

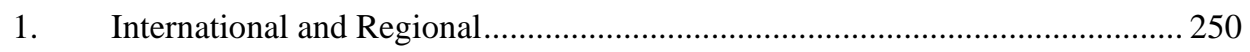

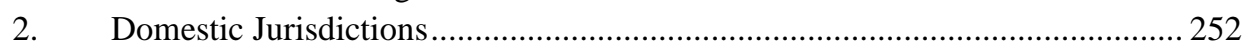

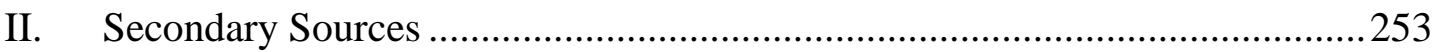

A. International and Regional Organisations' and their Organs' Declarations, Resolutions, Reports, Online Resources, Media Releases, Speeches and other Documents .............................................................................. 253

B. Journal Articles and Research Papers ...............................................264

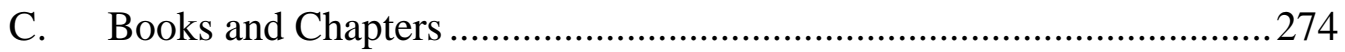

D. State and Non-State Organisations' and Persons' Reports, Online

Resources, Media Releases, and Speeches ..........................................284

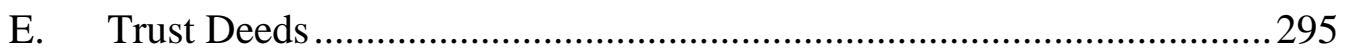

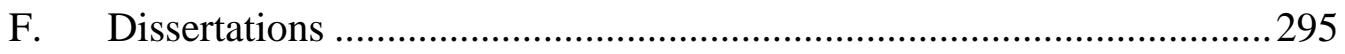




\section{List of Abbreviations}

\begin{tabular}{|c|c|}
\hline ALI & American Law Institute \\
\hline $\mathrm{BiH}$ & Bosnia and Herzegovina \\
\hline COP & Conference of the Parties to the UNFCCC \\
\hline EC & European Community \\
\hline $\mathrm{FBiH}$ & Federation of Bosnia and Herzegovina \\
\hline FRDP & Framework for Resilient Development in the Pacific \\
\hline FRY & Federal Republic of Yugoslavia \\
\hline GDP & Gross domestic product \\
\hline HRBA & Human rights-based approach \\
\hline ICCPR & International Covenant on Civil and Political Rights \\
\hline ICESCR & International Covenant on Economic, Social and Cultural Rights \\
\hline ICJ & International Court of Justice \\
\hline ILA & International Law Association \\
\hline ILC & International Law Commission \\
\hline IOM & International Organization for Migration \\
\hline IPCC & Intergovernmental Panel on Climate Change \\
\hline IRR & Impoverishment Risks and Reconstruction model \\
\hline NSGT & Non-Self-Governing Territory \\
\hline OCHA & United Nations Office for the Coordination of Humanitarian Affairs \\
\hline OECD & Organisation for Economic Co-operation and Development \\
\hline OHCHR & Office of the High Commissioner for Human Rights \\
\hline PCIJ & Permanent Court of International Justice \\
\hline PIF & Pacific Islands Forum \\
\hline UN & United Nations \\
\hline UNCLOS & United Nations Convention on the Law of the Sea \\
\hline UNDRIP & United Nations Declaration on the Rights of Indigenous Peoples \\
\hline UNEP & United Nations Environment Program \\
\hline UNESCO & United Nations Educational, Scientific and Cultural Organization \\
\hline UNFCCC & United Nations Framework Convention on Climate Change \\
\hline UNGA & United Nations General Assembly \\
\hline UNHCR & United Nations High Commissioner for Refugees \\
\hline UNSC & United Nations Security Council \\
\hline VCLT & Vienna Convention on the Law of Treaties \\
\hline
\end{tabular}




\title{
Chapter 1: Introduction, Problem Definition and Scope
}

\author{
$[P]$ eoples and provinces are not to be bartered about from sovereignty to \\ sovereignty as if they were mere chattels or pawns in a game... ${ }^{1}$
}

\section{Introduction}

Climate change is causing large-scale alterations to a multitude of Earth's natural systems. These changes will affect established human societies in progressively profound and adverse ways. For a handful of low-lying, small island, developing States (low-lying States), it is increasingly likely that multiple, compounding environmental changes will result in their entire territories becoming uninhabitable. ${ }^{2}$ As the former President of Kiribati, Anote Tong, explained, "[r]elocation, no matter how undesirable, must therefore be the brutal reality of the future of atoll island nations, and part of the solution". ${ }^{3}$

The international community has known of this risk for some time. In 1987, the President of the Maldives, Maumoon Abdul Gayoom, addressed the United Nations (UN) General Assembly (UNGA) in response to the Brundtland Report, Our Common Future. ${ }^{4}$ He warned that the sea-level rise forecast in that Report could lead to the "death" of his

1 Woodrow Wilson, President of the United States of America "War Aims of Germany and Austria" (11 February 1918) in Ray Stannard Baker and William E Dodd (eds) The Public Papers of Woodrow Wilson: War and Peace Presidential Messages, Addresses and Public Papers (1917-1924) (Harper \& Brothers, 1927) as cited in Hurst Hannum "Rethinking Self-Determination" (1993) 34 Va J Int'l L 1 at 4.

2 Leonard A Nurse and others "Small Islands" in Vicente R Barros and others (eds) Climate Change 2014: Impacts, Adaptation, and Vulnerability: Part B: Regional Aspects: Working Group II Contribution to the Fifth Assessment Report of the Intergovernmental Panel on Climate Change (Cambridge University Press, Cambridge, 2014), Chapter 29, [IPCC WGII AR5 Ch 29] at 1618 and 1620; Jon Barnett and W. Neil Adger, "Climate Dangers and Atoll Counties" (2003) 61 Climatic Change 321 at 326; Robert McLeman, "Climate Change Migration, Refugee Protection, and Adaptive Capacity Building" (2008) 4 McGill Int'1 J. Sust. Dev. L. \& Pol'y 1 at 11; Joanna M Foster "Epic King Tides Offer Glimpse of Climate Change in Marshall Islands" (6 March 2014) ThinkProgress <www.thinkprogress.org>.

3 Anote Tong "Climate Change Refugees: A Catastrophe of Our Own Creation" (20 June 2016) Medium <www.medium.com>.

4 World Commission on Environment and Development Report of the World Commission on Environment and Development: Our Common Future (United Nations, 20 March 1987). 
country and other low-lying States. ${ }^{5}$ These States, Gayoom explained, are extremely and uniquely vulnerable to the effects of climate change, and their entire territories could be irremediably affected, threatening their very existence as sovereign States.

The risks to low-lying States may be deferred by efforts to mitigate greenhouse gases, adapt in situ to the effects of climate change, and relocate intra-State. However, in situ adaptation may not be an option in the future, leaving cross-border migration a likely outcome. Except as an option of last resort, there is resistance to this highly sensitive topic. ${ }^{6}$ For instance, the current President of Kiribati, Taneti Maamau, explained at the 23rd Conference of the Parties (COP) to the United Nations Framework Convention on Climate Change (UNFCCC): ${ }^{7}$

\footnotetext{
... my Government has decided to put aside the misleading and pessimistic scenario of a sinking/deserted nation, and has replaced it with a bold scenario filled with great faith in the Mighty Hand, that made our islands, coupled with our people's unwavering love for their home land, and great determination to fight and/or adapt to climate change, with the help and support of our international partners and the entire world community.
}

With due respect to President Maamau's perspective, the scientific evidence indicates that, without dramatic increases in emissions mitigation and support for in situ adaptation, the scale of adverse effects could eventually undermine the capacities of low-lying States' to protect themselves. ${ }^{8}$ If this scenario plays out, the majority or entire populations of low-lying States will need to migrate across international borders.

5 Maumoon Abdul Gayoom, President of the Republic of Maldives "Address to the United Nations General Assembly" (42nd Session of the United Nations General Assembly on the Special Debate on Environment and Development, United Nations Headquarters, New York, 19 October 1987).

$6 \quad$ Nikita Perumal "'The places where I live is where I belong': community perspectives on climate change and climate-related migration in the Pacific island of Vanuatu" (2018) 13(1) Island Studies Journal 45 at 52; and Wilton Park Report: Navigating Pacific futures: climate change and resilience: Sunday 16 - Tuesday 18 December 2018 (report WP1631, March 2019) at [27].

7 H.E. Taneti Maamau "H.E sets the tone for his country in the face of Climate Change" (16 November 2017) Kiribati Updates <kiribatiupdates.com.ki>; and United Nations Framework Convention on Climate Change 1771 UNTS 107 (opened for signature 9 May 1992, entered into force 21 March 1994) [UNFCCC]. See also Niue Declaration on Climate Change, Annex B to Forum Communique, 39th Pacific Islands Forum, Alofi, Niue, 19-20 August 2008, Doc PIFS(08)6 [Niue Declaration], at preamble, fifth recital.

8 This Chapter, Part II. 
The word "migration" is an umbrella term that refers to movement away from one's habitual place of residence. ${ }^{9}$ Migration can be internal within a State or across an international border, voluntary or involuntary, or permanent or temporary, and the reasons for moving or a migrant's legal status are irrelevant. In this broad sense, migration in response to the effects of climate change is a recognised strategy for adapting to the effects of climate change. ${ }^{10}$ However, given the opposition to cross-border climate change-related migration (climate migration), such as Maamau's, it is appropriate to consider migration in these circumstances as a form of forced relocation, which, unlike voluntary migration, carries a range of human rights risks for those affected.

For most countries globally, climate migration will occur within affected individuals' States, because there is sufficient space and opportunity for this to occur. Therefore, cross-border migration will affect relatively small portions of most States' populations. However, in low-lying States, cross-border migration could affect most or all of their populations, so the situations and risks are unique. This thesis refers to this forecasted fact pattern of en masse cross-border climate migration as the "relocation scenario", and to the process of moving as the "relocation enterprise". In this relocation

$9 \quad$ IOM "Who is a migrant?" International Organization for Migration <www.iom.int>.

10 UNFCCC Report of the Conference of the Parties on its sixteenth session, held in Cancun from 29 November to 10 December 2010 FCCC/CP/2010/7/Add.1 (2011), Decision 1/CP.16, The Cancun Agreements: Outcome of the work of the Ad Hoc Working Group on Long-term Cooperative Action under the Convention [Cancun Adaptation Framework], at [14](f); UNFCCC Executive Committee of the Warsaw International Mechanism on Loss and Damage Letter from the UNFCCC Executive Committee of the Warsaw International Mechanism for Loss and Damage associated with Climate Change Impacts inviting organisations and experts to provide knowledge, data and scientific information on climate change-related internal and cross-border migration (ref EXCOM/MK/cma, 30 March 2016); UNFCCC Executive Committee of the Warsaw International Mechanism on Loss and Damage Technical Meeting: Action Area 6: Migration, Displacement and Human Mobility: Synthesis of relevant information, good practices and lessons learned in relation to Pillar 1 : Enhancing Knowledge and Understanding (UNFCCC Executive Committee of the Warsaw International Mechanism for Loss and Damage, Casablanca, July 2016); UNFCCC Executive Committee on Loss and Damage Report of the Executive Committee of the Warsaw International Mechanism for Loss and Damage associated with Climate Change Impacts: Draft decision -/CP.23 FCCC/SB/2017/L.5 (2017) at [7]-[8] and [13(c)]; OHCHR Report of the Special Rapporteur on the human rights of migrants A/67/299 (2012) at [88]; and W. Neil Adger and others "Human Security" in Christopher B Field and others (eds) Climate Change 2014: Impacts, Adaptation, and Vulnerability: Part A: Global and Sectoral Aspects: Working Group II Contribution to the Fifth Assessment Report of the Intergovernmental Panel on Climate Change (Cambridge University Press, New York, 2014) Chapter 12, 755 at 770 (citations omitted). 
scenario, the peoples' enjoyment of their collective right to self-determination is at risk. ${ }^{11}$ The central focus of this thesis is developing a robust understanding of this right, the risks that the relocation enterprise poses to self-determination, and options for addressing those risks. Thus, the central research question is, if the effects of climate change mean that entire peoples of low-lying States must relocate to other States' territories, what happens to their right to self-determination? ${ }^{12}$

The concepts of a people and of self-determination are examined throughout this thesis, but to introduce them briefly: a people is a collective group with common manifestations of nationhood, such as their national identity, language, culture, norms, customs, and shared histories. ${ }^{13}$ Self-determination is the collective right of a people to "freely determine their political status", to "freely pursue their economic, social and cultural development", and to "freely dispose of their natural wealth and resources". ${ }^{14}$ Self-determination is currently enjoyed by the peoples of low-lying states, but it will be challenged if the relocation scenario eventuates.

Orthodox migration schemes designed for individuals' movements will not protect this right to self-determination and, in fact, could exacerbate the risks. Existing pathways for cross-border migration are designed primarily for individuals, even where they are applied to many migrations. Therefore, an issue in the low-lying States' scenarios is that ordinary migration pathways risk fragmenting their peoples geographically and socially. ${ }^{15}$

In all likelihood, individuals from low-lying States will move gradually, perhaps over decades, and move to different destination States and different regions within those

11 Carol Farbotko and Heather Lazrus "The first climate refugees? Contesting global narratives of climate change in Tuvalu" (2012) 22(2) Global Environmental Change 382 at 388

12 Detailed research questions appear in part V(A) of this chapter.

13 UNESCO International Meeting of Experts on further study of the concept of the rights of peoples: UNESCO, Paris, 27-30 November 1989: Final Report and Recommendations SHS-89/CONF.602/7 (1990) at [22]-[23]; and see also Chapter 2, Part IV(A).

14 International Covenant on Civil and Political Rights 999 UNTS 171 (opened for signature 16 December 1966, entry into force 23 March 1976) [ICCPR], art 1.

15 Risks are described in this Chapter, Part III, including whether a people can be relocated in a united fashion when it will occur over time. 
States. They will also have the right to liberty of movement and freedom to choose their residence, ${ }^{16}$ which could lead to further fragmentation of their communities. Either fragmented or connected, low-lying peoples risk becoming small minorities within other States, rather than absolute majorities in their own States. This would involve expectations, to varying degrees, for assimilation into the dominant societies. ${ }^{17} \mathrm{With}$ time, these issues of fragmentation and assimilation mean that an approach to climate migration akin to ordinary migration would likely result in a gradual erosion of low-lying islanders' identity, culture, language, and other manifestations of nationhood. Hence, "[m]ere immigration does not satisfy the criteria necessary for a group to be self-determining even if the immigrants are treated justly." ${ }^{18}$ This problem has led Tuvaluan Prime Minister Enele Sapoaga to emphasise that "[m]aintaining sovereignty, self-determination, cultural identity and territorial rights are of primary concern to Pacific Islanders in any form. Forced displacement is a last option". ${ }^{19}$ In light of these challenges, the peoples' enjoyment of this right requires either preventing cross-border relocation or managing relocation in a way that seeks to enable its enjoyment ex situ.

This thesis focuses on the scenario whereby an entire people from a low-lying State is forced by the impacts of climate change to relocate across international borders, thereby jeopardising their enjoyment of the right to self-determination.

It does not seek to propose a single "correct" approach to addressing self-determination in the relocation scenario according to precise duties in international law. Instead, the objective is to provide guidance for this enterprise based in international law and practice. This involves interpreting and understanding the international law of self-determination in light of the relocation scenario, including as it relates to the question of statehood continuity. It also involves drawing together insights from prior experiences

16 ICCPR, art 12(1).

17 See Michael Savage "Tony Blair: migrants should be forced to integrate more to combat far right" The Guardian (online ed, London) 21 April 2019.

18 Cara Nine "Ecological Refugees, State Borders, and the Lockean Proviso" (2010) 27(4) Journal of Applied Philosophy 359 at 366.

19 Charlene Lanyon "Forced displacement last option, says Tuvalu PM" Fiji Times (online ed, Suva, 13 December 2016). 
of peoples and States addressing self-determination and key related policy matters: options for legal personality, land acquisition, and legal framework. Options in these regards can be assembled variously to produce sui generis regimes that allow the peoples of low-lying States to undertake relocation enterprises in ways that enable them to enjoy their right to self-determination. In turn, it is hoped that this understanding of the law of self-determination may contribute to shifting away from disaster-based narratives and into policy-making based on local empowerment.

Part V(A) of this chapter details the full scope of this thesis, but briefly, chapter 2 seeks to understand the law of self-determination. Chapter 3 investigates the duties of various actors regarding low-lying peoples' self-determination in relocation. Chapter 4 addresses questions on the continuity of the statehood of low-lying States, including relative to the self-determination analysis. Chapter 5 explores options for enabling lowlying peoples' self-determination in another State's territory. Finally, chapter 6 concludes the thesis.

The remainder of this chapter defines the problem and sets out matters of methodology. Part II summarises the problems climate change is causing for low-lying States. Part III explores known problems associated with forced relocation along with risks specific to the low-lying States. Part IV addresses terminology issues, part V sets out the scope and method, and part VI situates the author.

\section{Summary of Key Findings}

The key findings of this research are as follows. First, the low-lying peoples are entitled to self-determination, and it should be enjoyed ex situ, but this could be undermined if their right is not acknowledged in a binding legal instrument relating to their relocation. Secondly, the right to self-determination is comprised of a bundle of rights, with both substantive and procedural entitlements. Thirdly, low-lying States are the principal duty-bearers with respect to enabling their peoples' ex situ self-determination, but third-party States and others have general complementary duties. Fourthly, on the question of statehood, the low-lying peoples are exclusively competent 
to determine whether that legal personality continues, changes to an alternative personality, or is terminated. Fifthly, there are options for empowering the peoples to enjoy, ex situ, their right to self-determination. These options relate to central matters of legal personality, land acquisition, and the legal framework for their relocation enterprise. All options presented have precedents in international and municipal law and practice.

\section{Problems for Low-lying States and their Peoples Caused by Climate Change}

Climate change is a threat to human security in the broader sense of the term, which covers any threat to life or States, including environmental change. ${ }^{20}$ This is especially true in the low-lying States, which, as developing economies, already have limited capacity for resilience and adaptation to change. ${ }^{21}$ This part describes the impacts of climate change for low-lying States: the environmental changes; the human repercussions of remaining in the atoll territories; and the impediments to in situ adaptation.

The impacts of climate change on low-lying States are acute. Sea-level rose by approximately $19 \mathrm{~cm}$ between 1901 and $2010,{ }^{22}$ and the rate is increasing, having more than doubled from $1.3 \mathrm{~mm}$ per year in the 20th century to $3.1 \mathrm{~mm}$ per year since $1993 .{ }^{23}$

20 On the definition of "security", see Boe Declaration on Regional Security, adopted by the Pacific Island Leaders Forum, Boe, Nauru, 5 September 2018 [Boe Declaration] at preamble, fifth recital; and High-level Panel on Threats, Challenges and Change A More Secure World: Our Shared Responsibility: Report of the High-level Panel on Threats, Challenges and Change A/59/565 (2004) at 25 . On climate change as a security threat, see generally Denice Garcia "Warming to a Redefinition of International Security: The Consolidation of a Norm Concerning Climate Change" (2010) 24(3) International Relations 271; Rachel Kendall "Climate Change as a Security Threat to Pacific Islands" (2012) 16 NZJEL 83; and Climate change and its possible security implications GA Res 63/281, A/Res/63/281 (2009) [Resolution 63/281].

21 OECD and The World Bank Climate and Disaster Resilience Financing in Small Island Developing States (OECD and the World Bank, Washington DC, 2016) at 58.

22 John A Church and others "Sea Level Change" in Thomas F Stocker and others (eds) Climate Change 2013: The Physical Science Basis: Working Group 1 Contribution to the Fifth Assessment Report of the Intergovernmental Panel on Climate Change (Cambridge University Press, Cambridge, 2013) [IPCC WGI AR5], Chapter 13, 1137 at 1139.

23 Sönke Dangendorf and others "Reassessment of 20th century global mean sea level rise" (2017) 114(23) PNAS 5946. See also IPCC WGI AR5, above n 22, at 1140; and James Hansen and others "Ice melt, sea level rise and superstorms: evidence from paleoclimate data, climate modeling, and modern observations that $2^{\circ} \mathrm{C}$ global warming is highly dangerous" (2015) 15 ACPD 20059. 
Furthermore, in the tropical Pacific, where most low-lying States are situated, the rate of increase is up to four times higher than the global average. ${ }^{24}$ In addition to these facts, improved scientific understanding of factors contributing to sea-level rise is upwardly influencing forecasts. In 2013, the Intergovernmental Panel on Climate Change (IPCC) predicted sea-level to rise by an additional $82 \mathrm{~cm}$ by $2100 .{ }^{25}$ But more recent analysis suggests Antarctica alone will contribute one metre of sea-level rise by 2100 in addition to the levels previously forecast. ${ }^{26}$ Approximately 40 island nations around the world face severe consequences from sea-level rise and other climate change symptoms, ${ }^{27}$ but the countries commonly cited as being most at risk are Kiribati, the Maldives, the Marshall Islands and Tuvalu. ${ }^{28}$ Respectively, these States' average height above sea-level is $1.95 \mathrm{~m}$, $1.5 \mathrm{~m}, 2.1 \mathrm{~m}$, and $1.98 \mathrm{~m}$. While sea-level rise is only one issue, the forecasts of 0.8 to $1.8 \mathrm{~m}$ of sea-level rise ${ }^{29}$ characterise the scale of risk. Unlike other countries, the potential need for cross-border relocation may relate to low-lying States' entire populations. This gives rise to unique issues.

24 Nurse, above n 2, at 1619. The variability in the extent of sea-level rise is due to local geology and changes in ocean currents: see Melanie Fitzpatrick "What Accounts for the Varying Rates of Sea Level Rise in Different Locations?" (June 2013) Union of Concerned Scientists <www.ucsusa.org>.

25 IPCC WGI AR5, above n 22, at 1182 (table 13.5).

26 Robert M DeConto and David Pollard "Contribution of Antarctica to past and future sea-level rise" (2016) 531 Nature 591 at 591.

27 Koko Warner, Alex de Sherbinin, Susana Adamo and Tricia Chai-Onn In Search of Shelter: Mapping the Effects of Climate Change on Human Migration and Displacement (CARE International, May 2009) at 3.7.

28 UNHCR Climate Change and Statelessness: An Overview (United Nations High Commissioner for Refugees, submission to the 6th session of the Ad Hoc Working Group on Long-Term Cooperative Action (AWG-LCA6) Under the UNFCCC, 1 to 2 June 2009, Bonn, Germany, May 2009) at 1; and Susin Park Climate Change and the Risk of Statelessness: The Situation of Low-lying Island States (United Nations High Commissioner for Refugees, Legal and Protection Policy Research Series, May 2011) at 2. Tokelau is also completely at risk since its three atolls are only three-to-five metres above sea-level, but it is not an independent State. Whilst it has its own political bodies and judiciary, it remains a territory of New Zealand: Tony Angelo and Talei Pasikale Tokelau: A History of Government: The constitutional history and legal development of Tokelau (Council for the Ongoing Government of Tokelau, 2008) at 57; and Ministry of Foreign Affairs and Trade (NZ) "Tokelau" <www.mfat.govt.nz>. 
Low-lying States are also confronted by additional, compounding climate changerelated problems,${ }^{30}$ including: marine water pollution and salinisation of fresh water supplies, agricultural lands and fresh water ecosystems, ${ }^{31}$ intensification of weather extremes, such as rainfall events and heatwaves; ${ }^{32}$ flooding and inundation from sea-level rise, extreme events such as cyclones, or both; ${ }^{33}$ and erosion of coastlines and coastal developments. ${ }^{34}$ Moreover, ecosystem services will be compromised. Coral reefs, which protect island shores and provide habitat for marine species important for subsistence, will suffer bleaching and other damage. ${ }^{35}$ Similarly, mangroves, which provide food and materials, will be damaged by the greater depth and temperature of the sea. ${ }^{36}$

These environmental changes create adverse consequences for human health, including: direct mortality and injury from extreme weather events; increased incidences of vector-borne diseases, such as malaria and dengue fever; diseases from exposed landfill and burial sites following floods and inundation events; and compromised health from lack of access to freshwater and adequate nutrition. ${ }^{37}$ In Tuvalu, for example, declining yields are increasing reliance on imported foods, which has been linked to serious health problems, including diabetes. ${ }^{38}$ There are also mental health challenges arising from

Note that these problems are generalised here and that natural systems are complex and there are some naturally occurring processes that mitigate some of these events. However, the processes that mitigate these impacts are generally outstripped by the climate change phenomena that create these effects so that the overall effect is clearly negative: see generally IPCC WGII AR5 Ch 29, above n 2; and IPCC Global Warming of $1.5^{\circ}$ C: an IPCC special report: Summary for Policymakers (IPCC, October 2018).

31 Barnett and Adger, above n 2, at 322 and 326.

32 See generally Thomas F Stocker and others (eds) Summary for Policy Makers: Climate Change 2013: The Physical Science Basis: Working Group 1 Contribution to the Fifth Assessment Report of the Intergovernmental Panel on Climate Change (Cambridge University Press, Cambridge, 2013); and McLeman, above n 2, at 11.

33 IPCC WGII AR5 Ch 29, above n 2, at 1620; and see also Ove Hoegh-Guidberg and others "Impacts of $1.5^{\circ} \mathrm{C}$ global warming on natural and human systems" in IPCC Global Warming of $1.5^{\circ} \mathrm{C}$ : an IPCC special report (IPCC, October 2018), chapter 3, at 3-32.

34 IPCC WGII AR5 Ch 29, above n 2, at 1620-1621; and McLeman, above n 2, at 11.

35 IPCC WGII AR5 Ch 29, above n 2, at 1621.

36 At 1621.

37 At 1623-1625; Foster, above n 2; and Lachlan McIver and others "Assessment of Health Impacts of Climate Change in Kiribati" (2014) 11(5) Int. J. Environ. Res. Public Health 5224.

38 Shawn Shen and Francois Gemenne "Contrasted Views on Environmental Change and Migration: the Case of Tuvaluan Migration to New Zealand" (2011) 49(S1) International Migration 224 at 226. 
disaster events, the uncertainties associated with climate change, the chronic social and community effects, ${ }^{39}$ and from the relocation process itself. ${ }^{40}$

In summary, climate change and its symptoms are creating a plethora of human security risks in low-lying States, which are undermining the ability of people to remain in situ. These pressures are heightened by domestic challenges, such as low gross domestic product (GDP) and high unemployment. ${ }^{41}$ Even without these local issues, the scale of the impacts of climate change will be extreme, so "the actual damage costs for the small island states is enormous in relation to the size of their economies". ${ }^{42}$ In many parts of the world, climate-related relocation is intra-State, but the limited space in low-lying States may make this infeasible. Consequently, while relocation is an option of

39 Thomas J Doherty and Susan Clayton "The Psychological Effects of Global Climate Change" (2011) 64(4) American Psychologist 265. See also Jessica G Fritz and others "Hope, despair and transformation: Climate change and the promotion of mental health and wellbeing" (2008) 2 Int'l J Mental Health Systems 13; Fran H Norris and others "60,000 Disaster Victims Speak: Part I: An Empirical Review of the Empirical Literature, 1981-2001" (2002) 65(3) Psychiatry 207; and Maureen F Mooney and others "Psychosocial Recovery from Disasters: A Framework Informed by Evidence" (2011) 40(4) New Zealand Journal of Psychology 26. On the mental health effects of uncertainty, see: Michel Dugas, Nina Laugesen and William M Bukowski "Intolerance of Uncertainty, Fear of Anxiety, and Adolescent Worry" (2012) 40 J Abnorm Child Psychol 863; Julie Beck "How Uncertainty Fuels Anxiety" The Atlantic (online ed, Washington DC, 18 March 2015); and Nick Watts and others "Health and climate change: policy responses to protect public health" 386 The Lancet 1861 at 1877.

See Lori Uscher-Pines "Health effects of relocation following disaster: a systematic review the literature" (2009) 33(1) Disasters 1; Orit Nuttman-Shwartz, Rachel Dekel and Rivka Tuval-Mashiach "Post-Traumatic Stress and Growth following Forced Relocation" (2011) 41 British Journal of Social Work 486; Sara Sanders, Stan L Bowie and Yvonne Dias Bowie "Lessons Learned on Forced Relocation of Older Adults: The Impact of Hurricane Andrew on Health, Mental Health, and Social Support of Public Housing Residents" (2004) 40(4) Journal of Gerontological Social Work 23; Juan $\mathrm{Xi}$, Sean-Shong Hwang and Patricia Drentea "Experiencing a Forced Relocation at Different Stages of Life: The Effects of China's Three Gorges Project-induced Relocation on Depression" (2013) 3(1) Society and Mental Health 59; Jacquetta M Holder and David Jolley "Forced relocation between nursing homes: residents' health outcomes and potential moderators" (2012) 22(4) Reviews in Clinical Gerontology 301; and Dinesh Bhugra and Matthew A Becker "Migration, cultural bereavement and cultural identity" (2005) 4(1) World Psychiatry 18 at 19.

41 Jane McAdam Climate Change, Forced Migration, and International Law (Oxford University Press, Oxford, 2012) at 126-127.

42 Nurse and others, above n 2, at 1618. In the development of the Paris Agreement, negotiators from the United States were reportedly opposed to the inclusion of references to liability or compensation for damages because of the potentially high costs associated: Amanda Little "What the Paris Climate Agreement means for Vulnerable Nations" The New Yorker (online ed, 15 December 2015), referencing the Paris Agreement (opened for signature 16 February 2016, entered into force 4 November 2016) [Paris Agreement]. 
last resort, ${ }^{43}$ in situ adaptation may not be possible and cross-border relocation may be necessary. ${ }^{44}$

Climate change is already identified as a reason for migration by 23 per cent of I-Kiribati migrants and eight per cent of Tuvaluan migrants, ${ }^{45}$ and climate-related relocation is already happening in other parts of the world. ${ }^{46}$ But, for low-lying States, climate change-induced relocation may be necessary and permanent for their entire populations. As former I-Kiribati President Tong explained: ${ }^{47}$

\footnotetext{
Unless significant resources are to be made available from the developed world to build capacity to withstand the increasing severity of climate change impacts, a community's ability to adapt and to remain in its homelands would not be an option. ... Relocation, no matter how undesirable, must therefore be the brutal reality of the future of atoll island nations, and part of the solution.
}

\section{Problems Associated with En Masse Relocation}

Aggravating the environmental and human wellbeing problems caused by climate change itself, relocation will create significant challenges for the peoples of low-lying States. As Gromilova highlights, relocation will be "one of the most definitive moments

43 Andrea Milan, Robert Oakes and Jillian Campbell Tuvalu: Climate Change and Migration: Relationships Between Household Vulnerability, Human Mobility and Climate Change (Institute for Environment and Human Security, United Nations University, Report no. 18, November 2016) at 56; and Ropate Valemie "Climate Change" The Fiji Times (online ed, Suva, 22 March 2016).

44 Asian Development Bank A Region at Risk: The Human Dimensions of Climate Change in Asia and the Pacific (Asian Development Bank, 2017) at 90.

45 Robert Oakes and others Climate Change and Migration in the Pacific: Links, attitudes and future scenarios in Nauru, Tuvalu, and Kiribati (United Nations University Institute for Environment and Human Security, fact sheet, 2017).

46 Fiji, Papua New Guinea and Solomon Islands have had internal, climate-related migration: Ursula Rakova Submission to the Executive Committee of the Warsaw International Mechanism for Loss \& Damage: Information on Internal Displacement \& Relocation owing to factors relating to Climate Change Impacts: Actual (not Potential) Challenges (Tulele Peisa Inc, 10 May 2016); COP23 Fiji "How is Fiji Affected by Climate Change" <wwww.cop23.com.fj>; and SPREP Pacific Adaptation to Climate Change: Solomon Islands: Report of In-Country Consultations (SPREP, GEF and UNDP) at [71]. Fiji has developed guidelines for the process: and Ministry of Economy (FJ) Planned Relocation Guidelines: A framework to undertake climate change related relocation (Suva, 2018).

$47 \quad$ Tong, above n 3. 
for the lives of these people". ${ }^{48}$ These communities and their members face multiple, simultaneous losses and adaptations.

This part outlines some of the risks of en masse relocation by looking at the experiences of other communities subjected to involuntary relocation (often to make way for large-scale developments, such as hydroelectric dams), and at the issues particular to the peoples of low-lying States. The risks considered here are those regarding: first, self-determination and statehood; secondly, various forms of impoverishment in involuntary relocation; and thirdly, the uncertainties surrounding the relocation process. ${ }^{49}$ This brief survey illustrates the complexity of challenges that will confront the international community.

\section{A. Risks in International Law: Self-Determination and Statehood}

Relocation of entire peoples gives rise to risks for which international law is relevant. The scope of this thesis (outlined further in part V below) encompasses two key concepts: self-determination and statehood. Regarding self-determination, as noted in the introduction, orthodox migration schemes could transform low-lying islanders from being members of peoples with collective rights into members of minorities who are likely to be subjected to systemic pressures to acculturate into the societies into which they relocate. Combine these challenges with individual human rights risks, ${ }^{50}$ and the cumulative result is that the relocation scenario jeopardises the peoples' right to freely determine their political status, and to freely pursue their economic, social and cultural development. In other words, in a scenario where whole populations need to relocate, the peoples' ongoing enjoyment of the right to self-determination, as currently effectuated

48 Mariya Gromilova "Revisiting Planned Relocation as a Climate Change Adaptation Strategy: The Added Value of a Human Rights-Based Approach" (2014) 10(1) Utrecht Law Review 76 at 77.

49 Gromilova, above n 48, at 79-80, citing Michael M Cernea "Impoverishment Risks, Risk Management, and Reconstruction: A Model of Population Displacement and Resettlement" (Keynote Paper presented to the UN Symposium on Hydropower and Sustainable Development, Beijing, October 2000); and see Peter Ventevogel and others Mental Health and Psychological Support for Refugees, Asylum Seekers and Migrants on the Move in Europe: A Multi-Agency Guidance Note (United Nations High Commissioner for Refugees, IOM and the MHPSS Network, December 2015) at 3 .

50 This Chapter, Part III(B) below. 
through their existing sovereign States, is imperilled. Chapter 2 examines at length the risks to this right and how the law of self-determination applies to the low-lying States' factual situations, and chapter 3 examines various actors' duties relative to enabling low-lying peoples' enjoyment of self-determination in the relocation enterprise.

Related to self-determination is the risk to statehood. As the IPCC notes, "land inundation due to sea-level rise poses risks to the territorial integrity of small-island

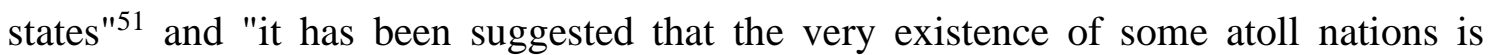
threatened by rising sea levels". ${ }^{52}$ Former I-Kiribati President Tong laments, "the reality [is] that their future as sovereign nations is in serious jeopardy." 53 This risk is recognised and being explored by the International Law Association (ILA) ${ }^{54}$ and the International Law Commission (ILC). ${ }^{55}$ The statehood issue is analysed in chapter 4 in light of the prior self-determination analysis.

\section{B. Impoverishment Risks with Planned Relocation, including a Proposal for a New Risk Category}

In addition to the risks to peoples' collective right to self-determination, individuals, families and communities affected by relocation face numerous challenges to their enjoyment of other human rights. As Gromilova notes, "[p]ast experiences with resettlement indeed show that removed populations end up worse off, largely due to a decline in their standards of living". ${ }^{56}$ Cernea developed a framework for understanding and addressing the challenges of forced relocation and resettlement, the Impoverishment

Christopher B Field and others Summary for Policy Makers: Climate Change 2014: Impacts, Adaptation and Vulnerability: Part A: Global and Sectoral Aspects: Contribution of Working Group II to the Fifth Assessment Report of the Intergovernmental Panel on Climate Change (Cambridge University Press, Cambridge, 2014) at 20.

52 IPCC WGII AR5 Ch 29, above n 2, at 1618.

53 Tong, above $\mathrm{n} 3$.

54 ILA Committee on International Law and Sea Level Rise Johannesburg Conference (2016) International Law and Sea Level Rise: Interim Report (International Law Association, 2016) at 11.

55 ILC Report of the International Law Commission: Seventieth session [2018] A/73/10, Annex B Sealevel rise in relation to international law, at [16].

56 Gromilova, above n 48, at 77-78, and 79, citing Cernea, above n 49. 
Risks and Reconstruction (IRR) model. ${ }^{57}$ This model, developed from a meta-analysis of relocation case studies, illustrates the hazards facing people in low-lying States. It categorises risks into eight themes: landlessness, joblessness, homelessness, marginalisation, food insecurity, increased morbidity, loss of access to common property, and social dislocation. These are summarised in Table 1 overleaf.

Arguably, the IRR model should include a new, ninth risk category for the peoples of low-lying States: cultural assimilation, which refers to the impoverishment of a sense of being a people. Following climate change-driven relocation of populations from low-lying States, their peoples will almost certainly assimilate to varying degrees into the destination communities' cultures, norms and languages at the expense of the former's nationhood. The concept of nationhood can be fraught in Western thinking, due to its associations with nationalism, homogeneity and political affiliations. ${ }^{58}$ However, for certain communities, such as those of low-lying States, nationhood relates to distinctive. cultures, historical heritages and processes: place, culture, kinship, collective narratives, sovereignty, and self-governing power. ${ }^{59}$ Nationhood is manifested in languages, cultures, norms, customs, protocols, and ways of life. All these aspects and expressions of nationhood are bolstered by, among other things, social systems that may be weakened by relocation

Migration can lead to cultural exchange between migrants and destination communities, and individuals are likely to adapt to new communities in very different ways. Some may thrive in the new environment. Regardless, relocation involves stresses which lead to acculturation processes ${ }^{60}$ First, 'affect aspects' are coping strategies devised for dealing with stresses. Secondly, 'behavioural aspects' involve cultural learning, such

57 Cernea, above n 49.

58 See generally Michal Rozynek "Nationhood and its Critics" in Michal Rozynek (ed) A Philosophy of Nationhood and the Modern Self (Palgrave MacMillan, New York, 2017) 41.

59 Stephen Cornell "Process of Native Nationhood: The Indigenous Politics of Self-Government" (2015) 6(4) The International Indigenous Policy Journal, article 4 at 4-5.

60 David L Sam and John W Berry "Acculturation: When Individuals and Groups of Different Cultural Backgrounds Meet" (2010) 5(4) Perspectives on Psychological Science 472 at 474. 
Table 1. Impoverishment risks observed in situations of forced relocation, ${ }^{61}$ including an additional risk for low-lying States.*

\begin{tabular}{|c|c|c|}
\hline & Landlessness & $\begin{array}{l}\text { Losing the foundation for livelihoods, including productive and } \\
\text { commercial activities, and land that has deep cultural values. }\end{array}$ \\
\hline 2) & Joblessness & $\begin{array}{l}\text { Prolonged challenges with unemployment and } \\
\text { underemployment. }\end{array}$ \\
\hline 3) & Homelessness & Loss of home, and of cultural space and traditional setting. \\
\hline 4) & Marginalisation & $\begin{array}{l}\text { Loss of capital, redundancy of skills, and a stigma and social } \\
\text { degradation of being "strangers". }\end{array}$ \\
\hline 5) & Food insecurity & $\begin{array}{l}\text { Particularly for communities that rely on subsistence or } \\
\text { micro-scale agriculture, access becomes limited and local } \\
\text { expertise becomes redundant. }\end{array}$ \\
\hline 6) & $\begin{array}{l}\text { Increased } \\
\text { morbidity }\end{array}$ & $\begin{array}{l}\text { Forced displacement leads to declines in physical and mental } \\
\text { health. }\end{array}$ \\
\hline 7) & $\begin{array}{l}\text { Loss of access to } \\
\text { common } \\
\text { property }\end{array}$ & $\begin{array}{l}\text { Loss of assets that belonged to the relocated communities, such } \\
\text { as cemeteries, community-owned properties, and buildings and } \\
\text { natural features with cultural heritage values. Abandonment of } \\
\text { public sector infrastructure, such as schools, hospitals, } \\
\text { government offices and Courts, all of which reflect local values } \\
\text { and ways of operating. }\end{array}$ \\
\hline 8) & $\begin{array}{l}\text { Social } \\
\text { dislocation }\end{array}$ & $\begin{array}{l}\text { Fragmentation of communities, patterns of social organisation, } \\
\text { and loss of social capital. }\end{array}$ \\
\hline 9) & $\begin{array}{l}\text { Cultural } \\
\text { assimilation* }\end{array}$ & $\begin{array}{l}\text { Loss of the sense of being a people through manifestations of } \\
\text { identity such as culture, norms and language. }\end{array}$ \\
\hline
\end{tabular}

61 Cernea, above n 49, at 13-21; Julia B Edwards "The Logistics of Climate-Induced Relocation: Lessons from the Carteret Islands, Papua New Guinea" 32(3) Refugee Survey Quarterly 52, at 67-75; Sophie Pascoe "Sailing the Waves on Our Own: Climate Change Migration, Self-Determination and the Carteret Islands" (2015) 15(2) QUT Law Review 72 at 76 and 79; Laurie Goering "As climate change uproots communities, innovation can rescue culture" (15 November 2016) Reuters <www.reuters.com>; UN News Centre "Climate change 'threatens self-determination' of citizens in island States, UN rights council told" (6 March 2015) <www.un.org>; and Ventevogel and others, above n 49, at 3 . 
as language and behavioural norms. Thirdly, 'cognitive aspects' entail how migrants think about themselves relative to intercultural encounters. With this acculturation process: ${ }^{62}$

... it is highly unlikely that the laws and lore from the places of origin and communal ways of living that still remain important in contemporary Pacific Island societies, especially in rural areas, could be sustained.

The risks to culture are an oft-cited concern of people from low-lying States. For instance, the President of the Marshall Islands, Hilde Heine, explains these risks, saying the Marshallese are "facing cultural extinction due to climate change" because "culture and land have a symbiotic relationship - one can't exist without the other." ${ }^{63}$ Similarly, Reverend Tafue Lusama, Secretary-General of the Christian Church of Tuvalu, has said: ${ }^{64}$

\begin{abstract}
When you relocate a whole country, cross border into another country, their distinctiveness and their identity will be lost. You know, they will become second, third or even fourth class citizens and assimilate into a totally different culture which is not theirs ... And that's a reality. Tuvalu as a nation, as a people, will disappear.
\end{abstract}

Such risks are apparent for the Tulun people of the Carteret Islands in Papua New Guinea. Their relocation involves shifting into a community with which they have kinship ties and which speaks the same language, Halia. However, the destination community has different values, beliefs and way of life. The risks to the Tulun people's way of life has added trauma to their relocation experience. ${ }^{65}$

62 John Campbell "Climate Change and Population Movement in Pacific Island Countries" in Bruce Burson (ed) Climate Change and Migration: South Pacific Perspectives (Institute of Policy Studies, Wellington, 2010) 29 at 40-41.

63 Jon Letman "Climate Change Is A 'Matter Of Life And Death' For The Marshall Islands" (4 November 2016) Honolulu Civil Beat <www.civilbeat.org>. The concerns are echoed by indigenous people in North America. See: Petition to the Inter American Commission on Human Rights Seeking Relief from Violations Resulting from Global Warming Caused by Acts and Omissions by the United States (7 December 2005) at 67; and Coral Davenport and Campbell Robertson "Resettling the First American 'Climate Refugees'" New York Times (online ed, New York, 3 May 2016).

64 Indira Stewart "Indigenous views crucial on climate change" (4 October 2018) Radio New Zealand <www.radionz.co.nz>.

65 Pascoe, above n 61, at 79. 
The risks of assimilation are greater if low-lying peoples move in opportunistic ways, rather than in relation to a systematic relocation enterprise that seeks to enable their enjoyment of self-determination. In piecemeal migrations, individuals' choices of destinations will be guided by, for example, where there are family members already. Other times, the choice will be limited to what opportunities are available, such as which countries' immigration regulations permit their relocation. Either way, there is a substantial risk of the people becoming geographically fragmented. This fragmentation exacerbates the risks of assimilation and highlights the need for relocation to be the subject of forward planning that respects the people as a self-determining unit, even where some individual members choose not to remain with the people. Thus, while it seems very likely that people will relocate gradually, rather than in a single operation, that progressive enterprise needs to be strategic and systematic to have the best chance of maintaining a sense of being a people; one with the right to self-determination.

The new Global Compact for Safe, Orderly and Regular Migration (Global Compact for Migration) does not ameliorate the risks of assimilation for low-lying peoples. ${ }^{66}$ Objective 16 of the Compact is to "empower migrants and societies to realize full inclusion and social cohesion", which implies some degree of assimilation. The Compact also seeks to "promote respect for diversity and inclusion", ${ }^{67}$ but the premise for Objective 17 is that "fully integrated migrants are better positioned to contribute to prosperity". ${ }^{68}$ The Compact asks States to establish programmes "about social norms and customs in the country of destination", ${ }^{69}$ and programmes that "improve integration outcomes". ${ }^{70}$ Integration may enhance outcomes for individual migrants and help avert dangerous forms of nationalism, ${ }^{71}$ but this policy objective challenges the nationhood and self-determination of low-lying peoples. The importance of preserving a people's unique characteristics is not acknowledged.

Global Compact for Safe, Orderly and Regular Migration (Internationally Negotiated and Agreed Outcome, 13 July 2018) [Global Compact for Migration].

67 At [32(i)].

68 At [32].

69 At [32(b)].

70 At $[32(\mathrm{f})]$.

71 Savage, above n 17. 
Acculturation pressures will impact on the embodiments of low-lying islanders' ways of life that are reasonably transportable, such as language, customs, crafts, and festivals. ${ }^{72}$ Certain other manifestations of nationhood are not transferable, such as culturally-significant land, and, a fortiori, the related risks are considerable. ${ }^{73}$ For low-lying peoples, the potential loss of homelands is the paradigmatic cultural risk, as Ronneberg explains: ${ }^{74}$

\begin{abstract}
There is ... a profound and deep connection of people to their land and oceans and all that it contains - it is the foundation of [Pacific Islanders'] culture, history, social and environmental interactions and existence.
\end{abstract}

Overall, the failure to mitigate climate change threatens nationhood by fragmenting communities, uplifting people from their homelands, and pressuring them to assimilate into new, dominant societies. These impacts have been labelled as "neo-colonialism", ${ }^{75}$ "adaptation apartheid", ${ }^{76}$ and "a slow and insidious form of terrorism"; ${ }^{77}$ characterisations which emphasise the scale of risk to these societies. The concern relative to the subject of this thesis is that cultural assimilation is incompatible with self-determination, particularly the aspect of being able to freely pursue cultural development. ${ }^{78}$ This incompatibility is illustrated by national policies regarding indigenous peoples that have

72 Andrew Potts of the International Council of Monuments and Sites, quoted in Goering, above n 61.

73 The loss of culturally and spiritually significant land has been particularly traumatic for the Tulun people: Pascoe, above n 61, at 79 and 83.

74 Espen Ronneberg quoted in SPREP "Climate induced displacement a stark reality for Pacific islands" (11 November 2016) <www.sprep.org>. Contrast one 'Western' perspective: "[T]here's no such thing as society": Margaret Thatcher in an interview in Women's Own (1987), quoted in "Margaret Thatcher: A Life in Quotes" The Guardian (online ed, London, 8 April 2013).

75 Amy Maguire and Jeffrey McGee "A Universal Human Right to Shape Responses to a Global Problem? The Role of Self-Determination in Guiding the International Legal Response to Climate Change" (2017) 26(1) RECIEL 54 at 64.

76 Desmond Tutu "We do not need climate change apartheid in adaptation" in Kevin Watkins and others Human Development Report 2007/2008: Fighting Climate Change: Human solidarity in a divided world (Palgrave Macmillan, New York, for the United Nations Development Programme, New York) 166 at 166.

77 Saufatu Sopoanga, Prime Minister of Tuvalu "Statement by the Honourable Saufatu Sopoanga OBE, Prime Minister and Minister of Foreign Affair of Tuvalu at the 58th General Assembly" (24 September 2003).

78 This aspect is discussed in Chapter 2, Part VII(A). 
sought to move away from assimilation and towards self-determination, as has happened in Australia. ${ }^{79}$

\section{Relocation Processes plus Associated Uncertainties}

Aggravating these issues, another layer of challenges relates to the processes of relocation. In this thesis, this is described as a "relocation enterprise". This language is chosen to emphasise that relocation will, in all likelihood, be a staged operation (for example, the Tulun people aim to resettle half of the population in Bougainville by 2020). ${ }^{80}$ It also reflects that it will be a long-term process, and ongoing beyond obvious milestones, such as the physical resettlement of people. Individuals, families, communities and any governance bodies they establish will take time to accustom themselves to their new homes. Any commitments to the relocation enterprise need to be enduring to minimise adverse outcomes, such as those described in the expanded IRR model.

However, there are no binding protection mechanisms for climate migrants international, regional or bilateral - and support for such mechanisms may wax and wane. For instance, on the one hand, the prevalence of nationalism is increasing globally, and it is associated with resistance to diversity and immigration. ${ }^{81}$ On the other hand, there are positive signals and momentum regarding climate migration. For example, the COP established the UNFCCC Executive Committee of the Warsaw International Mechanism for Loss and Damage (Executive Committee on Loss and Damage), which is examining "migration, displacement and human mobility". ${ }^{82}$ Also, all 193 Members of the UN

Michael Dodson, Aboriginal and Torres Strait Islander Social Justice Commissioner "Assimilation versus self-determination: no contest" (H.C. (Nugget) Coombs Northern Australia Inaugural Lecture, Darwin, 5 September 1996); and David Horton (ed) The Encyclopaedia of Aboriginal Australia (Aboriginal Studies Press, Canberra, 1994) at 68-70 and 977-978.

80 Edwards, above n 61, at 66-67.

81 Florian Bieber "Is Nationalism on the Rise? Assessing Global Trends" (2018) 17(5) Ethnopolitics 519 at 520, 524 and 528-529.

82 UNFCCC Executive Committee on Loss and Damage Report of the Executive Committee of the Warsaw International Mechanism for Loss and Damage associated with Climate Change Impacts FCCC/SB/2016/3 (2016); and Task Force on Displacement Report of the Task Force on Displacement (September 2018). 
adopted the New York Declaration for Refugees and Migrants (New York Declaration), which recognises the need for people to move in response to climate change. ${ }^{83}$ This Declaration was followed by the non-binding Global Compact for Migration, which was adopted by 152 States. ${ }^{84}$ Signatories agreed to "[d]evelop coherent approaches to address the challenges of migration movements in the context of sudden-onset and slow-onset disasters", ${ }^{85}$ albeit in the context of integration, as discussed above.

There are also regional initiatives. For example, the International Organization for Migration (IOM) has been delivering capacity building workshops on climate change and migration in the Pacific. ${ }^{86}$ It is also involved in a new project, "Enhancing Protection and Empowerment of Migrants and Communities Affected by Climate Change and Disasters in the Pacific Region". ${ }^{87}$ Also in the Pacific, the Polynesian Leaders Group adopted the Amatuku Declaration on Climate Change and Oceans (Amatuku Declaration), which states that: ${ }^{88}$

... the issue of climate change displacement and migration requires a regional response.

In this regard, we call for the establishment of a Grand Coalition of Pacific Leaders on

Climate Change Displacement and Migration to find regional solutions to the issue.

Bilateral initiatives are also emerging. Fiji has announced that it will assist Kiribati with climate migration if required, ${ }^{89}$ and New Zealand is exploring whether and how it might support Pacific climate migration. ${ }^{90}$ Thus, momentum for supporting climate

83 New York Declaration for Refugees and Migrants GA Res 71/1, A/RES/71/1 (2016) [New York Declaration] at [1], [18], [43] and [50].

84 United Nations "General Assembly Endorses First-Ever Global Compact on Migration, Urging Cooperation among Member States in Protecting Migrants" (19 December 2018) <www.un.org>.

85 Global Compact for Migration, above n 66, at [18(1)].

86 IOM "Training Workshops: Capacity-building Activities on Migration, Environment and Climate Change" <environmentalmigration.iom.int>.

87 IOM "Climate Change and Migration Project Launched to Protect, Empower Pacific Communities" (press release, 26 March 2019).

88 Amatuku Declaration on Climate Change and Oceans 8th Polynesian Leaders Group Meeting (29 June 2018) [Amatuku Declaration] at [11].

89 Office of the President of Kiribati "Fiji Supports Kiribati On Sea Level Rise" (press release, 11 February 2014).

90 Cabinet Office Circular "Pacific climate change-related displacement and migration: a New Zealand action plan" (May 2018, CAB-18-MIN-0218) [CAB-18-MIN-0218]. 
migration is beginning to emerge. The New Zealand initiative goes further by identifying self-determination as a value underpinning its work. Nonetheless, all declarations, statements and work programmes remain voluntary.

\section{Summary}

Parts II and III of this chapter have outlined the array of challenges facing the peoples of low-lying States, including the environmental problems, the impacts on wellbeing, and the additional problems associated with relocation. Governments, communities and international agencies will need to respond to these issues. The remainder of this chapter addresses matters of terminology before setting out the scope and methodology of this thesis in contributing to those actors' responses.

\section{Preliminary Matters of Terminology}

Before analysing relevant international law, important preliminary issues regarding terminology need to be addressed. It is commonly said that international law provides a vocabulary for international relations. ${ }^{91}$ It is, therefore, incumbent upon scholars and practitioners to promote language that is constructive and duly sensitive to affected peoples' circumstances.

\section{A. Migration, Relocation, Low-lying States, and Partner States}

In the context of discussing the low-lying States and their peoples, the common monikers of "climate refugees" and "environmental refugees" are problematic. Scholars, such as Rayfuse and Kahn, recognise these as "essentially negative concepts", ${ }^{92}$ which

91 Jan Klabbers International Law (Cambridge University Press, Cambridge, 2013) at 315; Malcolm N Shaw International Law (7th ed, Cambridge University Press, Cambridge, 2014) at 5; and James Crawford Brownlie's Principles of Public International Law (8th ed, Oxford University Press Oxford, 2012) at 15.

92 Rosemary Rayfuse "International Law and Disappearing States: Maritime Zones and the criteria for Statehood" (2011) 41(6) Environmental Policy and Law 281 at 284. 
imply that affected people are "passive victims who lack freedom of choice." ${ }^{93}$ More importantly, low-lying islanders themselves reject these concepts for those same reasons $^{94}$ and, hence, adopt alternate language, such as "migration with dignity". 95 There are also erroneous legal connotations attached to the term "refugee". It is well accepted that people who are forced to relocate due to climate change are not refugees under the 1951 Convention on the Status of Refugees (Refugee Convention). ${ }^{96}$ In this thesis, the residents of low-lying States are referred to simply as "low-lying peoples", "low-lying islanders", or similar. ${ }^{97}$

"Climate change-related migration" and "climate migration" are preferred alternatives to "refugee" concepts. This is because "migration" is an umbrella term that refers to any human mobility: internal or cross-border movement; temporary, circular or permanent movement; voluntary or involuntary relocation; regarding individuals or communities; and irrespective of the drivers of movement. ${ }^{98}$ Thus, "climate migration" clarifies the driver but remains intentionally open in all other respects.

When referring to the scenario at issue in this thesis, involving climate migration of whole populations of low-lying States, the phrase used here is "relocation enterprise". It builds on "planned relocation" used commonly in various humanitarian contexts. ${ }^{99}$

93 Matthew Kahn, University of California, in Consolidated Reply: Query: Promoting Economic Migration as a Climate Change Adaptation Strategy. Experiences; Advice (submission by the Climate Change and Development (CCD) Community of the Pacific Solution Exchange to the Executive Committee of the Warsaw International Mechanism for Loss and Damage on internal and cross-border migration, displacement and other forms of human mobility, 16 May 2016) at 7.

94 Perumal, above n 6, at 50-51; and ABC News "Pacific Islanders reject 'climate refugee' status, want to 'migrate with dignity', SIDS conference hears" (6 September 2014) <www.abc.net.au>.

95 Office of the President of Kiribati "Relocation" Kiribati Climate Change <www.climate.gov.ki>. This phrase was adopted by the United Nations as the theme of 2018's International Migrants Day: United Nations "International Migrants Day 18 December" <www.un.org>.

96 AF (Kiribati) [2013] NZIPT 800413; and Teitiota v Chief Executive of the Ministry of Business Innovation and Employment [2013] NZHC 3125, [2014] NZAR 162 at [44] and [51]; and Convention Relating to the Status of Refugees 189 UNTS 137 (opened for signature 28 July 1951, entered into force 22 April 1954) [Refugee Convention], art 1(A).

97 The concept of a "people" is discussed further in Chapter 2, Part IV(A).

98 IOM, above $\mathrm{n} 9$.

99 For example, Cancun Adaptation Framework, above n 10, at [14](f); UNHCR "Guidance on Protecting People from Disasters and Environmental Change through Planned Relocation" 
"Relocation" avoids confusion with common usage of "migration", which connotes voluntary cross-border movement, since climate migration is a form of forced relocation. ${ }^{100}$ And "enterprise" indicates the scale of what is involved.

Other problematic language includes referring to the low-lying States as "disappearing States", ${ }^{101}$ "sinking island States", ${ }^{102}$ and the like. ${ }^{103}$ The negative connotations of such terminology may have political appeal, but may also create a sense of fatalism that limits international support. ${ }^{104}$ There is also a power dynamic in this terminology. The negative connotations of "disappearing State" stand in contrast to the position of choice apparent in the phrase, "host State", which has common usage. ${ }^{105}$ This power dynamic risks exacerbating a sense of disempowerment already present in low-lying States from climate change itself. It may also perpetuate a systemic weakness and trigger a sense of reignited colonialism. Through a third world approach to international law, Chimni identifies an "alienation of international law from the peoples of the third world" and, in a relocation, refugee context, an "ongoing clash between the humanity of the victims and the rights of sovereign states to exclude [which] reflects the

(Brookings, Georgetown University and UNHCR, 7 October 2015); and Jane McAdam "Lessons from planned relocation and resettlement in the past" (2015) 49 Forced Migration Review 30.

100 See Perumal, above n 6, at 52.

101 OHCHR, above n 10, at [68]; Jane McAdam "'Disappearing States', Statelessness and the Boundaries of International Law" UNSW Law Research Paper No. 2010-2; and Rosemary Rayfuse "W(h)ither Tuvalu? International Law and Disappearing States" UNSW Law Research Paper No. 2009-9.

102 UNHCR, above $\mathrm{n} 28$, at 1.

103 Avery Kolers "Floating Provisos and Sinking Islands" (2012) 29(4) Journal of Applied Philosophy 333, which uses "sinking islands", "shipwrecked states" and "shipwrecked populations"; Nine, above n 18, which uses "ecological refugee states"; and Milla Emilia Vaha "Drowning under: Small island states and the right to exist" (2015) 11(2) JIPT 206, which uses "state-extinction".

104 UNHCR Summary of Deliberations on Climate Change and Displacement (United Nations High Commissioner for Refugees, April 2011) at [30]; and McAdam, above n 41, at 120.

105 For example, ILA Committee on International Law and Sea Level Rise Sydney Conference (2018) (International Law Association, 2018) at 25; Maxine Burkett "The Nation Ex-Situ: On climate change, deterritorialized nationhood and the post-climate era" (2011) 2 Climate Law 345 at 363; David Hodgkinson and others "The Hour When the Ship Comes In: A Convention for Persons Displaced by Climate Change" (2010) 36 Monash Univ L Rev 69; Abhimanyu George Jain "The 21st Century Atlantis: The International Law of Statehood and Climate Change-Induced Loss of Territory" (2014) 50(1) Stan J Int'1 L 1 at 49; McAdam, above n 41, at 52; Milla Emilia Vaha "Hosting the Small Island Developing States: two scenarios" (2018) 10(2) International Journal of Climate Change Strategies and Management 229; and Katrina Miriam Wyman "Responses to Climate Migration" (2013) 37 Harv Env'l Law Rev 167 at 187. 
estrangement of international law from its final subjects." 106 Perpetuating a known problem should be avoided. Moreover, as the scenario in this thesis relates also to low-lying States (as well as their peoples) entrenching a power imbalance through dichotomous language undermines a fundamental principle of international law: the sovereign equality of States. ${ }^{107}$

Another problem with the phrase "disappearing State" is that it could imply a legal outcome since a state is a legal personality. World leaders, including those of low-lying States employ language with similar connotations, saying that whole nations are at risk, or that their sovereignty is at risk, or that they face an existential threat. ${ }^{108}$ The political strategy is well-intended, but it may become a self-fulfilling prophecy. There are no rules or precedents that might suggest such outcomes are inevitable, so implying opinio juris that the personality of these States will "disappear" is fraught. As will be explored later, ${ }^{109}$ the rights of low-lying States and their peoples can be maintained ex situ while also maintaining third-party States' rights to territorial integrity and political independence. ${ }^{110}$ Thus, "disappearing States" and other language that presumes such a negative legal result should be avoided. ${ }^{111}$

Considering this discussion, this thesis refers to "low-lying States" by this simple moniker. It relies on an objective fact of their topography that links these States to a

106 BS Chimni "The Past, Present and Future of International Law: A Critical Third World Approach" (2007) Melb J Int'l Law 499 at 500 and 507.

107 Charter of the United Nations, art 2(1); Vienna Convention on the Law of Treaties 1155 UNTS 331 (opened for signature 23 May 1969, entered into force 27 January 1980) [VCLT] at preamble seventh recital.

108 For example, in visiting Tuvalu in 2019, UN Secretary-General António Guterres described it as "an entire country fighting to preserve its very existence": UN News "UN chief calls for 'enlightened selfinterest' from world leaders to save 'the whole planet' from climate change" (18 May 2019) <news.un.org>. Also, "President H.E. Anote Tong addressed the General Assembly of the United Nations ... and stressed that it was the Government's desire to 'maintain our homeland and our sovereignty": Office of the President of Kiribati "President tells of greatest challenge" (press release, 26 September 2009).

109 Chapter 5.

110 Charter of the United Nations, art 2(4).

111 UNHCR, above n 104, at [30]. 
common issue without implying weakness, or loss of sovereignty or legal personality. ${ }^{112}$ Other countries generally are referred to as "third-party States", while those States that might assist low-lying States in their relocation enterprises are referred to as "partner States". Compared to "host State", "partner State" implies only that they are "tak[ing] part in an undertaking with another". ${ }^{113}$ This descriptor respects the sovereign equality of States, and is used in the context of international solidarity and the principle of "[e]quitable, just and fair partnerships". ${ }^{114}$ The communities into which low-lying islanders relocate are referred to as "destination communities". ${ }^{115}$

\section{B. State and Nations}

The second issue of terminology is distinguishing the words "State" and "nation". In the drafting of the Charter of the United Nations (the Charter), there was some debate about distinguishing between a "State", a "nation" and a "people". ${ }^{116}$ Chapter 2 examines the meaning of a "people" in the low-lying States' context. ${ }^{117}$ Regarding "State", here it means "a real organized entity, a legal person with full authority to act under international law." 118 By comparison, "nation" refers to the "large body of people united by common descent, culture, or language", irrespective of the State or States within which its individuals and communities reside. ${ }^{119}$ Therefore, as Summers notes, "nation" closely resembles the notion of a "people"120 that have the collective right to

112 Contrast Rayfuse, above n 92, at 284: "As the territory of a threatened island State disappears beneath the waves, the criteria of territory will no longer be met and the claim to statehood will fail."

113 Catherine Soanes and Angus Stevenson (eds) Concise Oxford English Dictionary (11th ed, Oxford University Press, Oxford) at 1044.

114 Report of the Independent Expert on the right of peoples and individuals to international solidarity $\mathrm{A} / \mathrm{HRC} / 26 / 34$ (2014) annex ("Proposed draft declaration on the right of peoples and individuals to international solidarity") arts 2(e) and 11(2).

115 One alternative is "welcoming society": OHCHR, above n 10, at [53].

116 A Rigo Sureda The Evolution of the Right of Self-Determination: A study of United Nations Practice (A W Sijthoff, Leiden, 1973) at 97-101.

117 Chapter 2, Part IV(A).

118 Draft articles on Responsibility of States for Internationally Wrongful Acts, with commentaries [2001] vol II, pt 2 YILC 30 [Draft articles on State Responsibility] at 35.

119 Soanes and Stevenson, above n 113, at 952.

120 James Summers Peoples and International Law: How Nationalism and Self-Determination Shape a Contemporary Law of Nations (Martinus Nijhoff, Leiden, 2007) at 1-3. 
self-determination. ${ }^{121}$ Summers distinguishes the concepts on the basis that a nation can be broader than a people, and may also refer to political institutions. ${ }^{122}$ Here, however, nation is used interchangeably with people because of the low-lying peoples' expressed concerns about nationhood and national identity, which are manifested in culture, language and other such factors. Moreover, as will be discussed, the peoples of low-lying States are clearly defined in their existing countries in their entirety. ${ }^{123}$ It follows that, in these particular situations, the nations and the peoples are the same. The nation of Kiribati, for example, is the I-Kiribati people, whilst the State is the Republic of Kiribati. The distinction is not merely a fine point of terminology. If the outcomes sought are the maintenance of nationhood and its manifestations, then it does not automatically follow that continuity of statehood is essential. There is a range of mechanisms available, and it is for the peoples to freely determine which options they prefer.

\section{Scope and Method}

Having defined the problem and key terms, this part explains the approach of the thesis: the research scope and questions, and the use of international law as ex ante guidance to low-lying States' relocation enterprises.

\section{A. Research Scope and Questions}

This thesis is based on the scenario that the scale of environmental change will outstrip some low-lying States' in situ adaptation capacities and, therefore, ex situ solutions will be necessary for their entire peoples. Against this scenario, this thesis focuses on analysing rights and duties for low-lying peoples and their States, focusing on the right to self-determination. The importance of this right is examined later, ${ }^{124}$ but

\footnotetext{
121 ICCPR, art 1(1); and International Covenant on Economic, Social and Cultural Rights 993 UNTS 3 (opened for signature 16 December 1966, entered into force 3 January 1976) [ICESCR], art 1(1).

122 Summers, above $\mathrm{n} 120$, at 2-3.

123 Chapter 2, Part IV(A).

124 In particular, Chapter 2, Part VI(A).
} 
briefly, the primary reason for focusing on self-determination is that it is foundational to individual human rights and to statehood, among other things.

The research questions for this thesis were:

- Do the peoples of low-lying States have the right to self-determination?

- If so, should they enjoy it in the relocation scenario?

- If so, what is self-determination, that is, what should low-lying peoples expect?

- Who are the duty-bearers regarding low-lying peoples' self-determination and what is the nature of their duties?

- Does the right influence whether statehood can exist in low-lying States' relocation scenarios?

- Is it feasible for low-lying peoples to enjoy self-determination ex situ?

In answering all these questions, ${ }^{125}$ the thesis is structured as follows. Chapter 2 seeks to deconstruct and understand what is the right to self-determination; that is, what entitlements and obligations it produces. This analysis involves examining the right's applicability to low-lying islanders; its legal status and relevance; its objectives; its external and internal forms; and its procedural and substantive aspects. Chapter 3 then analyses potential duty-bearers and their respective duties towards the peoples of low-lying States regarding their ex situ self-determination. The overall investigation into self-determination in chapters 2 and 3 seeks to identify relevant elements of the right which may be important to the relocation enterprise.

Regarding statehood, chapter 4 explores whether a low-lying State can continue as a legal person at international law if its territory becomes wholly uninhabitable because of climate change. This involves examining the presumption of statehood continuity, its relationship to self-determination, and how it affects the need for extant States to satisfy

125 A summary of key findings appears in Part I of this Chapter, page 6. 
the traditional indicia of statehood enumerated in the Montevideo Convention on the Rights and Duties of States (Montevideo Convention). ${ }^{126}$

Chapter 5 identifies relevant options in international and municipal law and practice to reduce the risks to self-determination associated with relocation and to enable the ex situ enjoyment of that right. Specifically, it looks at options regarding legal personalities, modes of land tenure, and legal frameworks. Chapter 5 also considers how the human rights-based approach to climate change adaptation can be adapted for the objective of enabling ex situ self-determination. The options are assembled in hypotheticals to illustrate how they may function together.

The challenges facing low-lying States and the international community generally could be explored relative to many other areas of law and practice, including: State sovereignty; territorial integrity; law of the sea; responsibility to protect; international solidarity; sustainable development; international security; economic rights of States; the rights of indigenous peoples; and the right to development. However, those topics are beyond the scope of this thesis. Climate change law (climate law) is also relevant, and some elements are considered briefly, but only as relevant to understanding self-determination matters.

\section{B. Using International Law as Ex Ante Guidance for Low-Lying States' Relocation Enterprises}

Another important methodological aspect of this research relates to the use of international law as a tool for ex ante guidance regarding the low-lying States' challenges. The low-lying States' predicaments can be considered relative to potential ex post legal liabilities of polluting States, which is how some scholars have approached the topic. ${ }^{127}$

126 Montevideo Convention on the Rights and Duties of States 165 LNTS 19 (opened for signature 26 December 1933, entered into force 26 December 1934) [Montevideo Convention], art 1.

127 For example, Will Frank "Climate Liability under Public International Law" (summary of the author's article in German, "Überlegungen zur Klimahaftung nach Völkerrecht" (2014) 33 Neue Zeitschrift für Verwaltungsrecht - Extra 1); International Bar Association Achieving Justice and Human Rights in an Era of Climate Disruption: Climate Change Justice and Human Rights Task Force Report (July 
But the success of low-lying States' relocation enterprises (however success is measured) will depend on effective working relationships with partner States, and on the development of new, targeted policies, amongst other things. Effective partnerships will not be built on apportioning liability. For this reason, the approach here is to develop a robust understanding of relevant international law so that it can helpfully inform policy development, as Higgins suggests. ${ }^{128}$

Employing international law as a basis for policy aligns with Hathaway's "integrated theory of international law". ${ }^{129}$ According to this theory, States commit to and comply with international law, not because of judicial enforcement per se, but because of other incentives. These incentives are: expected oversight and enforcement by domestic actors, such as independent courts, individuals and groups $;{ }^{130}$ expected oversight and enforcement by international actors, such as international organisations and third-party States through retaliation measures; ${ }^{131}$ the anticipated collateral consequences in the reactions of domestic actors, such as those who will benefit through commitment and compliance; ${ }^{132}$ and finally, the anticipated collateral consequences in the reactions of international actors, particularly in relation to how a country is viewed by those actors and the consequences that follow. ${ }^{133}$ Such incentives are part of why it is legitimate to refer to international law for policy development for emerging issues.

2014) at 66 and 85; Jenny Grote Stoutenburg "When Do States Disappear? Thresholds for Effective Statehood and the Continued Recognition of 'Deterritorialized Island States" in Michael B Gerrard and Gregory E Wannier (eds) Threatened Island Nations: Legal Implications of Rising Seas and a Changing Climate (Cambridge University Press, Cambridge, 2013) 57 at 85; and Roda Verheyen and Peter Roderick Beyond Adaptation: The legal duty to pay compensation for climate change damage (WWF-UK, November 2008) at 15-24.

Rosalyn Higgins Problems \& Process: International Law and How We Use It (Oxford University Press, Oxford, 1994, reprinted 2010) at 5-10. See also Harold Hongju Koh "Foreword: America's Conscience in International Law" in Michael P Scharf and Paul R Williams Shaping Foreign Policy in Times of Crisis: The Role of International Law and the State Department Legal Advisor (Cambridge University Press, New York, 2010) xi at xiv.

29 Oona Hathaway "Between Power and Principle: An Integrated Theory of International Law" (2005) 72 University of Chicago Law Review 469.

At $497-500$.

At 500-502.

At 502-504.

At 504-511. 
The subject of the thesis involves a novel factual setting, and the law it considers suffers from ambiguity. In that light, it would be unnecessarily limiting to "think of international law as something which a hypothetical court might decide if it were given jurisdiction in an international dispute". ${ }^{134}$ Instead, the law is interpreted relative to the emerging facts so as to inform the development of responsive policies and support measures.

For this exercise, a doctrinal analysis was conducted, that is, research seeking to understand relevant rules relative to the factual problem. ${ }^{135}$ This involved: examining primary sources of international law; analysing the uses of self-determination by adjudicating bodies, such as the International Court of Justice (ICJ), the UNGA, the UN Security Council (UNSC) and other UN agencies; and interpreting the text of treaties in light of the factual scenario at issue. ${ }^{136}$ The doctrinal analysis also involved reviewing related analyses by experts in governmental and civil society organisations, and in academia. For the policy development aspect, this thesis also relies on reform-oriented research, that is, research examining the adequacy of current rules and making recommendations. ${ }^{137}$ This involved examining international, regional, national, non-governmental and individuals' declarations, resolutions, research papers, reports, media releases, speeches, websites and other secondary materials.

\section{The Author's Subjective Context and Implications for Research Findings}

This thesis deals with issues of profound importance to the peoples of low-lying States. Research, particularly from other social sciences, repeatedly finds strong

134 Anthony D'Amato "The Relation of Theories of Jurisprudence to International Politics and Law" (1970) 27 Wash \& Lee L Rev 257 at 263-264 (emphasis in original).

135 See Terry Hutchison and Nigel Duncan "Defining and Describing What We Do: Doctrinal Legal Research" (2012) 17(1) Deakin Law Review 83 at 101.

136 See VCLT, art 31. See generally Richard Gardiner Treaty Interpretation (2nd ed, Oxford University Press, Oxford, 2015); and see also Michał Gondek The Reach of Human Rights in a Globalising World: Extraterritorial Application of Human Rights Treaties (Intersentia, Mortsel, Belgium, 2009) at 30-39.

137 At 101. 
resistance to relocation because of the vast personal, social and cultural implications. My experience from meeting with people throughout the Pacific is that the subject is increasingly sensitive. It is important to recognise that, since I am not from a low-lying State, I have a limited perspective from which to consider the problem, interpret the law and devise possible solutions. The analyses in this thesis are not an attempt to talk "on behalf of" low-lying peoples, nor an attempt to find "the" answer to their situations. With respect for and deference to low-lying islanders, their lives, experience, and expertise, this thesis attempts to offer some insights from an international law perspective in the hope that it may assist with their attempts to determine their own futures.

\section{Conclusion}

The crises emerging for low-lying States are vast and multi-faceted: the environmental changes; the need for relocation; and the plethora of risks resulting from said relocation. The aim of this research is to examine the international law of self-determination and statehood to provide ex ante, strategic guidance to the development of responsive and aspirational policies and initiatives that support low-lying peoples' relocation enterprises. The next chapter addresses the preliminary question: what is self-determination? 


\section{Chapter 2: The Meaning of Self-Determination in the Context of Low-lying Peoples' Relocation Enterprises}

\section{Introduction}

In broad terms, self-determination is the right of peoples to determine their own political destiny, and to ordain their own values, norms and ways of life. The right is enjoyed today by low-lying peoples and States, both de facto and de jure. However, in the many ways self-determination is currently manifested, its continued enjoyment could be severely challenged by the climate change scenario, particularly if relocation is piecemeal and the peoples are fragmented. ${ }^{138}$ For instance, low-lying States could lose their sovereign independence, ${ }^{139}$ which would, in turn, endanger their peoples' ability to jointly decide on their destinies. ${ }^{140}$ Wholesale relocation may undermine the ultimate authority of low-lying States to establish and enforce rules and norms among their population. ${ }^{141}$ Their sovereign rights to natural resources, which are critical for economic development and social wellbeing, are imperilled. Finally, the status of statehood, and all the rights that are attached to that, also appears to be at risk. ${ }^{142}$ These risks are in addition to the problems described earlier in this thesis. ${ }^{143}$ In their totality, these risks illustrate why the Marshall Islands has described the possibility of being reclassified as "a displaced nation" as "an affront to self-determination and national dignity." 144

138 Jane McAdam and others International Law and Sea-Level Rise: Forced Migration and Human Rights (Fridtjof Nansens Institutt, University of New South Wales, and the Andrew and Renata Kaldor Centre for International Refugee Law, FNI Report 1/2016, January 2016) at [41].

139 Jörgen Ödalen "Underwater Self-determination: Sea-level Rise and Deterritorialized Small Island States" (2014) 17(2) Ethics, Policy \& Environment 225 at 226.

140 Flavia Pansieri, United Nations Deputy High Commissioner for Human Rights "Address to the FullDay Discussion on Human Rights and Climate Change" (Full-Day Discussion on Human Rights and Climate Change, Palais des Nations, Geneva, 6 March 2015); UN News Centre, above n 61; and Nathan Jon Ross "Climate Change Risks to Representative Government in Kiribati" (2014) 20 NZACL Yearbook/(2015) 21 CLJP/JDCP 91.

141 Ödalen, above n 139, at 232.

142 McAdam, above n 41, at 158; and see Chapter 4.

143 Chapter 1, Part III.

144 Phillip H Muller "National Communication regarding the Relationship Between Human Rights \& The Impacts of Climate Change" (Permanent Mission of the Republic of the Marshall Islands to the United Nations, submission to the United Nations Human Rights Council, 31 December 2008) at 10. 
Given the risks to self-determination and the fundamental conditions necessary for its maintenance ex situ, this chapter seeks to answer two central questions. First, will the peoples of low-lying States remain entitled to the right to self-determination post-relocation? Secondly, what is the substance of this right; what are the peoples of low-lying States entitled to by virtue of self-determination?

The central finding from answering these questions is that climate change-induced relocation does not extinguish the right to self-determination belonging to the affected peoples. The analysis also finds that self-determination gives rise to high-level entitlements: the right of low-lying peoples to determine their political statuses, and to freely pursue their economic, social and cultural development. Practically, a degree of political and administrative autonomy is required to enjoy these entitlements.

To reach these findings, and following a brief introductory description of self-determination in part II, this chapter contains five further substantive parts. Part III details the risks particular to self-determination. Part IV examines the low-lying peoples' continued entitlement to self-determination ex situ. In part V, a brief survey of the right's evolution reveals its status in international law and begins to shed light on the responsibilities of third parties, which are further explored in chapter 3. Parts VI and VII dissect and examine the contents of self-determination.

For those parts VI and VII, a framework is proposed for understanding the right. In this framework, illustrated in Figure 1, the right is divided into strategic and operational aspects. Part VI analyses the strategic elements, which are the right's overarching objectives, and the internal and external dimensions of self-determination. Part VII examines the operational aspects of the right, which can inform how the right may work in practice in the relocation enterprises of low-lying States. These operational aspects are divided into substantive and procedural entitlements. Substantive entitlements anticipate certain outcomes or ends, while procedural entitlements do not seek particular results, but rather provide for processes where the peoples (and sometimes other stakeholders) have input into decision-making. This framework is based on common approaches to policy 
development, which starts with questions such as, What are we trying to achieve? and How will we get there?

Self-determination also involves correlative duties for various stakeholders, particularly the negative obligation to refrain from taking measures that adversely affect the enjoyment of the right to self-determination by peoples of other States. These duties are examined in chapter 3 .

Figure 1. The proposed framework for deconstructing and understanding the right to self-determination.

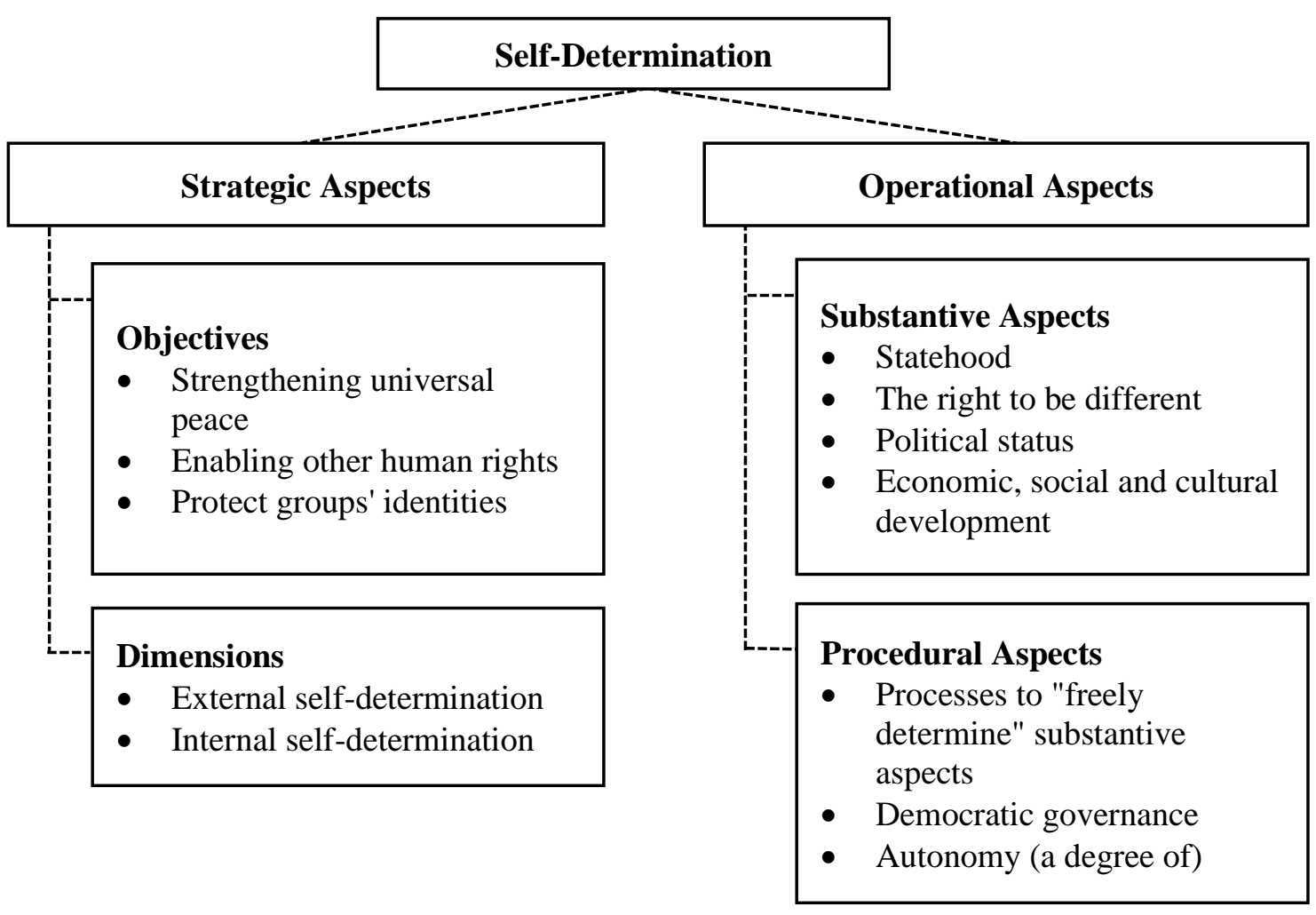




\section{Self-Determination: A Brief Sketch}

The nature and contents of self-determination will be examined in depth throughout this chapter, but a brief introduction is offered here to frame the remainder of the discussion.

Self-determination is a right belonging to "all peoples", and by virtue of that right, a people (considered in the singular, since it is a collective right) can "freely determine their political status and freely pursue their economic, social and cultural development." 145

These compact statements are powerful enough that self-determination became, according to Cassese, "emblematic of law in the twentieth century", but conceptually challenging and lacking in a clear definition, thereby creating "a veritable Pandora's box". ${ }^{146}$ The concept is rich in aspiration and was the main legal driving force for decolonisation and the creation of a multitude of new States. But, simultaneously, it remains ill-defined and, where it creates new States, self-determination subverts other core principles of international law: sovereignty, territorial integrity and non-interference in the affairs of other States. ${ }^{147}$ Moreover, the concept has never been tested in situations resembling the low-lying States' climate change relocation enterprises. The challenge here, therefore, is to draw on existing law, practice and scholarship to build a credible theory for how this enigmatic concept might function in this emerging 21 st century setting.

The common conceptual framework for analysing this right is that "external self-determination" is where a people form an independent State, and "internal self-determination" is where a people is recognised as an effective group within an

145 ICCPR, art 1(1); and ICESCR, art 1(1).

146 Antonio Cassese Self-Determination of Peoples: A Legal Reappraisal (Cambridge University Press, Cambridge, 1995) at 1.

147 At 333. 
existing State and has a special relationship with that State. ${ }^{148}$ A classic illustration of external self-determination was with the creation of new States during decolonisation. A classic illustration of internal self-determination is where indigenous peoples and the State have a particular and significant relationship. For the low-lying States, there are questions about the continuity of statehood which, therefore, challenges their continued external self-determination. Additionally, relocating citizens could remove them from the State with which they have a special relationship, thereby challenging internal self-determination as a people. These issues are considered further throughout the chapter.

\section{Risks to Self-Determination}

The many implications of climate change for low-lying States, particularly in the relocation scenario, amount to a challenge to the continuing enjoyment of the right to self-determination. ${ }^{149}$ The earliest international recognition of this risk appears to occur in 2008, in a submission made by the Maldives to the Office of the UN High Commissioner for Human Rights (OHCHR). The Maldives explained that climate change would "cause the denial of the right to self-determination of the Maldives people." 150 In the same year, the Marshall Islands argued similarly that "[t]he reclassification of Marshallese as a displaced nation, or, loosely defined, as 'climate refugees,' is not only undesirable, but also unacceptable as an affront to self-determination and national

148 Crawford, above n 91, at 647; Thomas M Franck "The Emerging Right to Democratic Governance" (1992) 86 Am J Intl Law 46 at 52; Bryan A Garner (ed) Black's Law Dictionary (10th ed, Thomson Reuters, St Paul MN, 2009) at 1565 and also 1522; Higgins, above n 128, at 116-117; Kathleen McVay "Self-Determination in New Contexts: The Self-Determination of Refugees and Forced Migrants in International Law" (2012) 28(75) Merkourios 36 at 49-51; David Raič Statehood and the Law of Self-Determination (Kluwer Law International, The Hague, 2002) at 227; Summers, above $n$ 120, at 31; Daniel Thürer and Thomas Burri "Self-Determination" in Rüdiger Wolfrum (ed) The Max Planck Encyclopedia of Public International Law (Oxford University Press, Oxford, 2013) 113.

149 Chapter 1, Part III(A).

150 Submission of the Maldives to the Office of the UN High Commissioner for Human Rights under Human Rights Council Resolution 7/23 "Human Rights and Climate Change" (25 September 2008) at 7. 
dignity." ${ }^{151}$ More recently, in 2016, the Special Rapporteur on the issue of human rights obligations relating to the environment was also forthright, explaining: ${ }^{152}$

If the residents of small island States are forced to evacuate and find other homes, the effects on their human rights, including their right to self-determination and to development, will be devastating.

The risks to self-determination are most apparent when the relocation enterprise is envisaged as being conducted only through relatively ordinary migration schemes. Under such policy settings, where the focus is on moving people but not protecting self-determination, low-lying islanders would transform socially and politically from being members of an outright majority in their own States to being members of minorities in the destination State. ${ }^{153}$ Although, as a minority, they "shall not be denied the right ... to enjoy their own culture", ${ }^{154}$ expatriate low-lying islanders will, nonetheless, be subject to the "tyranny of the majority". ${ }^{155}$ This has significant ramifications for the peoples' self-determination. First, each people's independence from other political units would be undermined, since its members would become subjects of the destination States. ${ }^{156}$ Secondly, each people's ability to decide collectively on their communities' destinies would be trammelled by the laws and norms of the destination States. ${ }^{157}$ Related to that, simple migration solutions would undermine the people's ultimate authority to establish and enforce rules and norms among their members, as this role would be the exclusive jurisdiction of the destination State. ${ }^{158}$ Indeed, in the en masse climate migration scenario, low-lying States may risk losing statehood and the rights attached to that status. ${ }^{159}$

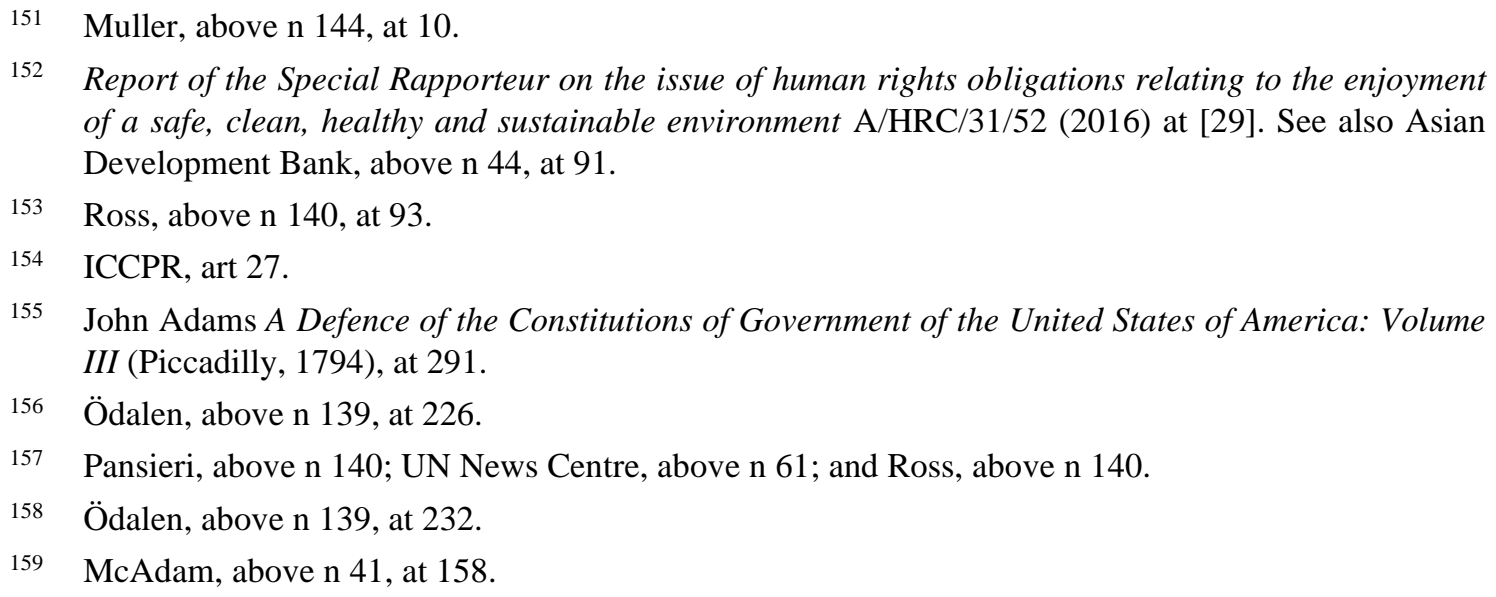


One notable consequence of the loss of statehood, if that were to occur, ${ }^{160}$ would be the peoples' loss of sovereign rights to natural resources, which are critical for economic and social wellbeing, and for development. ${ }^{161}$ All these imperilled aspects of self-determination are analysed in depth in this chapter.

Given the fundamental challenges that the relocation scenario poses to collective decision-making powers, it follows that the aspects of nationhood reflected in the machinery of the State are also at risk. Willcox explains: ${ }^{162}$

... there is something worth preserving here that is not captured by the planned relocation proposal: a constitution and set of political institutions that have been shaped over time to reflect shared values and pursue distinctive collective goals; a unique political entity recognized as a member of the international community; and the capacity to be self-determining as Tuvaluans or I-Kiribati, rather than as the newest members of the state of New Zealand.

Overall, it is clear the relocation of entire peoples to the territories of other States may jeopardise their continued enjoyment of self-determination; ${ }^{163}$ a risk that would be exacerbated if the communities were fragmented into multiple destination States. While these risks are driven by climate change and climate law is thereby relevant, the specific risks to self-determination warrant its direct examination and application to the problem.

160 Loss of statehood is sometimes assumed, but with dubious legal reasoning. See Chapter 4.

161 Permanent sovereignty over natural resources GA Res 1803 (XVII) (1962) [Resolution 1803].

162 Susannah Willcox "Climate Change Inundation, Self-Determination, and Atoll Island States" (2016) 38 Human Rights Quarterly 1022 at 1024 (citations omitted).

163 Pansieri, above n 140. 
IV. The Ex Situ Continuity of the Right to Self-determination in ClimateInduced Relocation

Having concluded that the factual climate change scenario imperils low-lying peoples' enjoyment of self-determination, and on the premise that this is worth preserving, ${ }^{164}$ the first step in the analysis is determining whether the affected peoples would continue to be eligible for that right ex situ. This involves determining whether they each are a people, and can remain so in another State, rather than becoming a minority. Ongoing eligibility also depends on whether the peoples' right to self-determination was exhausted upon gaining independent statehood following decolonisation. Examining that question includes looking at the implications of other analyses that have posited that self-determination has been reconceptualised as a predominantly procedural right.

\section{A. Rights-Holders: as a "People" or a "Minority"}

In Raič's historical analysis of the post-World War II decolonisation period, self-determination reflected a territorial definition of who held the right, rather than an ethnic definition. ${ }^{165}$ Post-decolonisation, it evolved into a people's right to govern themselves. ${ }^{166}$ Today, the 1966 human rights Covenants specify that self-determination is a collective right belonging to a "people". ${ }^{167}$ Therefore, a legal threshold for self-determination is finding that a collective group is a people and, in the case of the low-lying islanders, that these groups could, following climate migration, each remain as peoples in the territories of destination States.

\footnotetext{
164 This premise is examined further in Part VI(A) of this Chapter.

165 Raič, above n 148, at 444.

166 At 445.

167 ICCPR, art 1(1); ICESCR, art 1(1); and see also Summers, above n 120, at 1.
} 
In some cases, identifying a people has been relatively straightforward, such as with the East Timorese, Palestinians and Kosovars. ${ }^{168}$ It remains unclear, however, what criteria must be met, since there is no universally-accepted definition of a people. ${ }^{169}$ Importantly, as indicated in the travaux préparatoires for the Charter ${ }^{170}$ and the International Covenant on Civil and Political Rights (ICCPR), ${ }^{171}$ it does not apply only to colonised peoples, as will be discussed in the next section, ${ }^{172}$ nor only to peoples under alien domination. In the development of the Charter, dialogue regarding "peoples" indicated that it "refers to groups of human beings who may, or may not, comprise states or nations." 173 This "all-embracing"174 conceptualisation is unhelpful and later attempts have been made to reach a more nuanced definition. It is now considered that determining the existence of a people is a question of fact. For example, according to a group of experts convened by the United Nations Educational, Scientific and Cultural Organization (UNESCO), this question of fact is examined relative to four common characteristics of a people, which are intentionally descriptive, not definitive. ${ }^{175}$ The first of these features is that the group enjoys some or all of the common features of historical tradition, ethnic identity, culture, language, religion, territorial connection and economic life.

East Timor (Portugal v Australia) (Judgment) [1995] ICJ Rep 90 [East Timor] at 105-106 [37]; Legal Consequences of the Construction of a Wall in the Occupied Palestinian Territory (Advisory Opinion) [2004] ICJ Rep 136 [Israeli Wall advisory opinion] at 182-183; and Independent International Commission on Kosovo The Kosovo Report: Conflict, International Response, Lessons Learned (2000, Oxford University Press, Oxford) [The Kosovo Report] at 186.

Gillot et al v France (Communication) (2000) HRC CCPR/C/75/D/932/2000 at 13.16; Lea Brilmayer "Secession and Self-Determination: A Territorial Interpretation" (1991) 16 Yale J Int Law 177 at 198; Allen Buchanan "Self-Determination, Revolution and Intervention" (2016) 126(2) Ethics 447 at 470; James Crawford The Creation of States in International Law (2nd ed, Oxford University Press, Oxford, 2006) at 124-125; Hannum, above n 1, at 35-39; Jan Klabbers "The Right to be Taken Seriously: Self-Determination in International Law" [2006] 28 Human Rights Quarterly 186 at 194; Thürer and Burri, above n 148, at 117-118; Higgins, above n 128, at 126; Sarah Joseph and Melissa Castan The International Covenant on Civil and Political Rights: Cases, Materials, and Commentary (3rd ed, Oxford University Press, Oxford, 2013) at 154-155; and Summers, above n 120, at 1-2.

170 Sureda, above n 116, at 100 and see generally 97-101.

171 Manfred Nowak U.N. Covenant on Civil and Political Rights: CCPR Commentary (2nd revised ed, N. P. Engel, Kehl, Germany, 2005) at 20.

172 This Chapter, Part IV(B).

173 Sureda, above n 116, at 100, citing United Nations Documents of the United Nations Conference on International Organization, Volume XVIII (UNIO/VOL.18, 1954) at 657-658.

174 Sureda, above n 116, at 101.

175 UNESCO International Meeting of Experts on further study of the concept of the rights of peoples: UNESCO, Paris, 27-30 November 1989: Final Report and Recommendations SHS-89/CONF.602/7 (1990), at [22]-[23]. 
Secondly, the group is more than a mere association of individuals. Therefore, and thirdly, the group as a whole identifies as, or has the consciousness of being, a people. Fourthly, the group has institutions or other ways of expressing its common characteristics and its will for identity.

Knop surveys discussions on what comprises a "people" and, in particular, the debate as to whether a 'people' is determined by demos - a political nation - or by ethnos - a cultural community based on common language. ${ }^{176}$ In particular, she recognises that colonised people may not have been either, but their "collective injury of colonialism" is what they share: "they were defined by a wrong". ${ }^{177}$ She proposes an alternative account, that "[a] people is au fond a community of fate, the inhabitants of a territory defined by forces beyond their control." 178

Raič's account is "a people in the social and cultural or anthropological sense and thus concerns an ethnic definition of 'peoplehood'."179 Willcox's approach is to consider a people as "a collective unity constituted by a history of mutual cooperation in the shared political institutions of a state". ${ }^{180}$ According to Schacter, a "people" cannot be defined generally, as it depends entirely on individual circumstances and context considered through lenses of reasonableness and appropriateness. ${ }^{181}$

In any of the above definitions, the present-day communities of each low-lying State readily meet the requirements. Critically, since the relocation scenario relates to whole populations, the key is that the low-lying peoples are defined relative to their existing countries. But more evidence is available. Ethnically, the I-Kiribati, Marshallese

176 Karen Knop Diversity and Self-Determination in International Law (Cambridge University Press, Cambridge, 2002) at 55.

177 At 56-57.

178 At 56.

179 Raič, above n 148, at 446.

180 Willcox, above n 162, at 108, drawing on Anna Stilz "Nations, States and Territories" (2011) 121(3) Ethics 572.

181 Oscar Schachter "The Relation of Law, Politics and Action at the United Nations" (1963) 109(II) Hague Recueil 169 at 193-194. 
and Tuvaluans populations are very homogeneous, ${ }^{182}$ as is the Maldivian population, even with its higher proportion of immigrant foreigners (15.8 per cent). ${ }^{183}$ The populations within each low-lying State share common religions, cultures, traditions, public institutions, and territorial and maritime connections. This is not to suggest these peoples lack diversity, but that commonality brought about by, and reflected in, the existing States is such that the question of whether each State's population is a people does not require extensive analysis. It would be erroneous for another State to dispute that the Tuvaluans, for example, are a people since they currently enjoy self-determination.

Having said that, there is a risk that a partner State expects the low-lying State's nationals will be a "minority", not a people, once they relocate to the partner State's territory. Does relocation demote a people into a minority? There is no clear definition of a minority and it is again a question of fact. ${ }^{184}$ For instance, the Council of Europe Framework Convention for the Protection of National Minorities "contains no definition of the notion of 'national minority'. Instead it was decided to adopt a pragmatic approach". ${ }^{185}$ However, to illustrate the concept, Capotorti proposes four requirements: ${ }^{186}$

The term "minority" may be taken to refer to: A group numerically inferior to the rest of the population of a State, in a non-dominant position, whose members-being nationals of the State-possess ethnic, religious or linguistic characteristics differing from those of the rest of the population and show, if only implicitly, a sense of solidarity, directed towards preserving their culture, traditions, religion or language.

182 National Statistics Office (KI) "2015 Population and Housing Census: Volume 1: Management Report and Basic Tables" (Ministry of Finance, September 2016) at 32, 52 and 56; Central Intelligence Agency "The Marshall Islands" The World Factbook <www.cia.gov> and SPC "Tuvalu - Tuvalu Population and Housing Census 2012" (Secretariat of the Pacific Community, 14 July 2016) Pacific Data Library <pdl.spc.int>.

183 National Bureau of Statistics (MV) "Statistical Release 1: Population and Households", "Table PP 5: Resident Population by Sex, Nationality and Locality (Administrative Islands), 2014" Ministry of National Planning and Infrastructure <www.statisticsmaldives.gov.mv>.

184 UN Minority Rights: International Standards and Guidance for Implementation (HR/Pub/10/3, 2010) at 2 .

185 Framework Convention for the Protection of National Minorities ETS 157 (1 February 1995) [European Minorities Convention], Explanatory Report, at [12].

186 Francesco Capotorti Human Rights Study Series 5: Study on the Rights of Persons Belonging to Ethnic, Religious and Linguistic Minorities (United Nations, New York, 1991) at [568]. 
There are conceptual overlaps between a minority and a people, hence the theoretical possibility of either concept applying to low-lying islanders residing in a partner State. However, the legal classification has markedly different outcomes. As a minority, low-lying islanders could assert art 27 of the ICCPR, which stipulates that:

\footnotetext{
In those States in which ethnic, religious or linguistic minorities exist, persons belonging to such minorities shall not be denied the right, in community with the other members of their group, to enjoy their own culture, to profess and practise their own religion, or to use their own language.
}

The Human Rights Committee notes that, whilst this is an ostensibly-negative obligation, State parties are obliged to take positive protection measures. ${ }^{187}$ Similarly, while art 27 appears to be owed only to individuals, the enjoyment of the right depends "on the ability of the minority group to maintain its culture, language or religion". ${ }^{188}$ Therefore, State obligations are to protect the individual "in community with the other members of the group". ${ }^{189}$ Thus, the Human Rights Committee points to States having two positive obligations: ensuring that "the existence and the exercise of this right are protected against their denial or violation"; 190 and taking measures "necessary to protect the identity of the minority and the rights of its members to enjoy and develop their culture and language". ${ }^{191}$ Cassese notes, however, that legal entitlements for protection and remedy are asserted as members of minorities, not as a minority group. ${ }^{192}$

In contrast to the rights of a minority, a people with the right to self-determination can determine an international legal status as external self-determination, or expect a

Human Rights Committee General Comment Adopted by the Human Rights Committee under Article 4, Paragraph 4, of the International Covenant on Civil and Political Rights: Addendum: General comment No. 23(50) (art.27) CCPR/C/21/Rev.1/Add.5 (1994) [General Comment 23] at [6.1]; and see also Margaretha Wewerinke "A Right to Enjoy Culture in the Face of Climate Change: Implications for 'Climate Migrants'" (2013) CGHR Working Paper \#6 / 4CMR Working Paper \#7, Cambridge Centre for Climate Change Migration Research, University of Cambridge, at 10-11.

189 At [6.2].

190 At [6.1].

191 At [6.2].

192 Cassese, above n 146, at 328-329. 
special relationship with the State as internal self-determination, all in pursuit of their economic, social and cultural development. ${ }^{193}$ And as will be discussed later, ${ }^{194}$ self-determination contains a bundle of derivative rights, with substantive and procedural elements, and there is a practical requirement for a degree of autonomy. Altogether, self-determination creates much higher standards and expectations than what can be asserted in minorities' right of non-discrimination, and rights to culture, religion and language. The Human Rights Committee has, therefore, cautioned that minorities' rights to culture should not be confused with peoples' rights to self-determination. ${ }^{195}$

If determining whether a group was a minority or a people was based purely on numbers, low-lying islanders may have great difficulty securing self-determination. Hypothetically, if all 11,000 Tuvaluans moved to New Zealand, then why would they be entitled to self-determination and all it entails, ${ }^{196}$ and not just minority rights, compared to the 163,000 Chinese, the 144,000 Samoans, or the 143,000 Indians who live in New Zealand $?^{197}$ Whilst there is a tension in international law between the concepts of "minority" and "people", ${ }^{198}$ there are at least three key facts that distinguish Tuvaluans and other migrant groups in this hypothetical. First, the Tuvaluans would be arriving under entirely different circumstances. Climate-induced, forced relocation is different to sought-after lifestyle migration, and their receipt by destination States will likely be based on climate and humanitarian reasons rather than ordinary policy bases, such as seeking skilled or investor migrants, or enabling family reunions.

Secondly, the Tuvaluans in this scenario are an entire people, unlike members of the other nationalities who immigrate. Thirdly, they are already defined as a people and

\footnotetext{
193 This Chapter, Part VI(B).

194 This Chapter, Part VII.

195 General Comment 23, above n 187, at [2].

196 This Chapter, Part VII.

197 These are the three largest ethnic groups in New Zealand other than New Zealand European/Pākehā and Māori: Statistics New Zealand "2013 Census QuickStats about culture and identity" (14 April 2014) <www.stats.govt.nz>.
}

198 Summers, above n 120, at 5. 
are seeking to ensure that status is not compromised by forced relocation. ${ }^{199}$ Although there is no guiding precedence, it is argued here that these three facts distinguish the Tuvaluans from other foreign ethnic groups such that their legal status as a people remains unaffected.

In addition to these factual distinctions, it will be important to reinforce the people status by securing legal recognition, for example, in an agreement between the low-lying and destination States. This would create a legal distinction between climate migrants and other migrants, reflecting the factual distinctions. Options for such legal arrangements are discussed in chapter 5. ${ }^{200}$ If a low-lying State's population is fragmented across multiple third-party States, then any relevant legal arrangements and other facts will become highly relevant in determining whether they remain a people, transform into minorities, or some combination of the two. Three scenarios illustrate this. First, if all or a majority of members of a people relocate to the same destination State, there seems no grounds nor mechanism in international law for terminating a people's extant de jure status of being a people with the right to self-determination. As will be explained in the following section, the right belongs to a people, not "a people within a particular territory", so it should follow the people in relocation. ${ }^{201}$ Indeed, the destination State will have certain duties to the people with regard to this collective right. ${ }^{202}$ Importantly, however, the fortune of each people will depend in part on the efficacy of assertions of external self-determination and the outcomes of negotiations with the partner State regarding internal self-determination. If their status as a people with the right to self-determination is reaffirmed in a relevant agreement in international law, the matter would be resolved.

A second scenario may be where there is a central community in one destination State and diaspora in others. The central community would act as the "population nucleus"203 for the people's continuity. The diaspora would be minorities in their

199 Many indigenous populations have been forcibly relocated and the question of their collective identity as a people is not undermined by this fact.

200 Chapter 5, Part IV.

201 This Chapter, Part IV(B)(1).

202 This Chapter, Part VIII(B).

203 Stoutenburg, above n 127, at 65. See also Chapter 4, Part VI(B). 
destination States but may benefit from activities done by the central community on behalf of the people collectively. Again, a legal agreement could reaffirm the status of the central community as a people. One challenging aspect in such scenarios is whether diasporas are entitled to enjoy the collective right in any way, relative to the central community. There are numerous precedents for diasporas participating in government via external voting and overseas constituencies. ${ }^{204}$ Furthermore, the Council of Europe adopted: 205

\footnotetext{
$\ldots$ the right of persons belonging to national minorities to establish and maintain free and peaceful contacts across frontiers with persons lawfully staying in other States, in particular those with whom they share an ethnic, cultural, linguistic or religious identity, or a common cultural heritage.
}

Guidance from other jurisdictions is not dispositive, however. The participation of diasporas in self-determination measures would be a matter of bilateral or plurilateral arrangements, and the "municipal" legal and governance arrangements established by the low-lying people's central community and their governance body.

A third general scenario might involve there being only diasporas across several destinations, with no central community. It would be a perpetual challenge to maintain connectivity, national identity, and other practical matters that would support continued legal or even de facto status as a people. Certainly, if there were no relevant legal arrangements, it would be available for each destination State to consider the low-lying islanders as individual members of minorities, not as a collective people. Whilst third-party States have general duties with respect to all peoples' self-determination, ${ }^{206}$ it would be difficult to claim against those obligations without an acknowledgement that the low-lying peoples are a people with the right to self-determination. This re-emphasises the importance of having a legal agreement that acknowledges this right.

204 Andrew Ellis and others Voting from Abroad: The International IDEA Handbook (International Institute for Democracy and Electoral Assistance and the Federal Electoral Institute of Mexico, 2007) at 28-30; and Catherine Dauvergne Making People Illegal: What Globalization Means for Migration and Law (Cambridge University Press, Cambridge, 2008) at 133-134

205 European Minorities Convention, art 17(1).

206 Chapter 3, Part II(B). 
These three scenarios highlight again the risks associated with fragmentation by contrasting that scenario with others that involve a core community which functions as the population nucleus for the continuity of status of a people. The scenarios also indicate how agreements in international law would bolster this legal status.

\section{B. A Right beyond Decolonisation}

In addition to determining whether the populations of low-States are peoples, another potential barrier to the relevance of self-determination is whether it applies outside decolonisation situations, which relate to a people within a certain territory. The right is often associated with decolonisation and the formation of new, independent States (external self-determination). Garner, for example, refers to self-determination as a "right of post-colonial populations". ${ }^{207}$ This association may be due to the context in which the General Assembly endorsed one of its earliest resolutions regarding self-determination, the Declaration on the granting of independence to colonial countries and peoples [Resolution 1514]. ${ }^{208}$ The General Assembly focused on "the passionate yearning for freedom in all dependent peoples" and recognised "that the peoples of the world ardently desire the end of colonialism in all its manifestations."209

However, interpreting self-determination as relevant only to decolonisation is erroneous for two reasons. First, the right belongs to a people and does not rely on territorial connection. Secondly, the relevance of the right has not been limited to decolonisation cases by either treaty or adjudicatory pronouncements. These arguments are discussed below.

Garner, above n 148, at 1522 .

Declaration on the granting of independence to colonial countries and peoples GA Res 1514 (XV) (1960) [Resolution 1514].

At preamble, third and sixth recitals. 


\section{The Right Belongs to a People, not a Territory}

The first basis for why the right to self-determination is not limited to decolonisation situations is that it does not rely on territorial connection. ${ }^{210}$ One basis for this conclusion is that it is principally a procedural right. ${ }^{211}$ According to an analysis by Klabbers, "judicial and quasi-judicial bodies have, since the 1970s, reconceptualized the right of self-determination to come to terms with the (virtual) end of decolonization" and, consequently, self-determination is "best understood as a procedural right" or "a bundle of procedural rights". ${ }^{212}$ Maguire and McGee also suggest that "self-determination must be understood as a process, rather than any single outcome of that process." ${ }^{213}$ Conceiving self-determination this way "sever[s] the connection between self-determination and territory" 214 because, primarily, it is no longer implemented to create new States out of decolonisation, ${ }^{215}$ which require defined territories. ${ }^{216}$ It will be argued later that self-determination also has substantive aspects, not just procedural. However, none of its substantive entitlements are inextricably linked to a particular territory, such as the right of a people to their difference.

Another reason why self-determination does not rely on territorial connection, proposed here, is that the right belongs to "all peoples"217 and not, say, "all peoples in defined territories". As discussed earlier, ${ }^{218}$ determining whether a group of individuals

210 Judge Cançado Trindade observed a general evolution in international law involving "conditions of living of the population" being "a key aspect", such that, although "[p]eople and territory go together ... the emphasis has shifted from the status of territory to the needs and aspirations of people": Accordance with International Law of the Unilateral Declaration of Independence in Respect of Kosovo (Advisory Opinion) (2010) ICJ Rep 403 [Kosovo Independence advisory opinion] at [65] (Judge Cançado Trindade).

211 On the procedural and substantive aspects of self-determination, see Part VII of this Chapter.

212 Klabbers, above n 169, at 189 and 202. See also Summers, above n 120, at 30-33; and Maguire and McGee, above n 75, at 66 .

213 Maguire and McGee, above n 75, at 66 (citations omitted). See also Klabbers, above n 169, at 189; and Summers, above n 120, at 33.

214 Klabbers, above n 169, at 202.

215 At 189.

216 Montevideo Convention, art 1.

217 ICCPR, art 1(1); and IESCR, art 1(1).

218 This Chapter, Part IV. 
comprise a people is a question of fact and territorial connection is just one of several indicators that are weighed up. Moreover, this connection does not need to be continued and contemporary. Perhaps the most prominent example of this in practice is with the internal self-determination of indigenous peoples. Each indigenous people's distinction from the remainder of the State's population relates to, among other things, their ancestral territories; not necessarily to contemporary territories, because of forced evictions during colonisation. ${ }^{219}$ Their right to self-determination persists despite "the nonavailability of large territorial units in which the group is preponderant." ${ }^{220}$ This is reflected in the United Nations Declaration on the Rights of Indigenous Peoples (UNDRIP). It recognises that indigenous peoples have suffered from dispossession of their lands and territories, ${ }^{221}$ but still have the right to self-determination. ${ }^{222}$

For low-lying islanders, with existing de facto and de jure self-determination, their territorial connection is contemporary. And, since the right does not require territorial connection, it is not automatically extinguished by sole virtue of relocation. Moreover, territory is not a practical necessity. It provides the strongest foundations for self-determination, but there is an array of options for framing the relocation of low-lying States, their peoples, or both, and only one option involves the partner State ceding territory, while others involve holding land under different forms of tenure. ${ }^{223}$

\section{The Right Belongs to a Peoples, not only in Decolonisation}

A second basis for proposing that self-determination may continue ex situ is that, although decolonisation was the right's most remarkable expression, that phenomenon is

219 Benedict Kingsbury "Self-Determination and 'Indigenous Peoples'" (1992) 86 Proceedings of the American Society of International Law 383 at 386.

$220 \quad$ At 386.

221 United Nations Declaration on the Rights of Indigenous Peoples GA Res 61/295, A/Res/61/295 (2007), annex ('United Nations Declaration on the Rights of Indigenous Peoples') [UNDRIP], at preamble, sixth recital.

222 Article 3.

223 Chapter 5, Part III; and see also Chapter 4, Part VI(D). 
not the limit of the right's relevance. ${ }^{224}$ As an "inalienable"225 right that belongs and is applicable to "all peoples", ${ }^{226}$ it is contended here that decolonisation is a subset of the wider concept of self-determination. Therefore, the right was not spent with the low-lying States' decolonisation.

Although the right is not fully explained or understood outside decolonisation situations, it remains relevant beyond that phenomenon. Hannum has identified that "now that colonialism is effectively over ... the international community has moved toward a new definition of self-determination ... [that] has become infused with broadly defined human, minority, and indigenous rights". ${ }^{227}$ This was confirmed by the ICJ in its advisory opinion on the Legal consequences of the separation of the Chagos Archipelago from Mauritius in 1965 (Chagos Archipelago), stating::228

The Court is conscious that the right to self-determination, as a fundamental human right, has a broad scope of application. However, to answer the question put to it by the General Assembly, the Court will confine itself, in this Advisory Opinion, to analysing the right to self-determination in the context of decolonization.

224 Higgins, above n 128, at 115-128. For a discussion on the travaux préparatoires of the ICCPR, see Nowak, above n 171, at 10-13. See also James Crawford "The Rights of Peoples: Some Conclusions" in James Crawford (ed) The Rights of Peoples (Clarendon Press, Oxford, 1988) 159 at 169-170.

225 Question of Palestine GA Res 3236, XXIX (1974) at [1(a)]. The rule that the right to self-determination is inalienable is prevalent in decolonisation contexts, including Resolution 1514, above n 208, at preamble, eleventh recital; Resolution 384 SC Res 384 (1975) at preamble, fourth recital; Southern Rhodesia SC Res 460 (1979) at [1]; and Importance of the universal realization of the right of peoples to self-determination and of the speedy granting of independence to colonial countries and peoples for the effective guarantee and observance of human rights GA Res 37/43, A/Res/37/43 (1982) at preamble, ninth recital and [3].

226 ICCPR, art 1(1); ICESCR, art 1(1); and Declaration on Principles of International Law concerning Friendly Relations and Cooperation among States in accordance with the Charter of the United Nations GA Res 2625, XXV (1970) [Friendly Relations Declaration] at 123. See also Organisation for Security and Co-operation in Europe (OSCE) Conference on Security and Co-operation in Europe (CSCE): Final Act of Helsinki (1 August 1975) [Helsinki Final Act], art 1(a)(VIII); ILC Report of the International Law Commission on the work of its fortieth session [1988] vol II, pt 2 YILC 1 at 64 [266]-[267].

227 Hurst Hannum "Self-Determination in the Twenty-First Century" in Hurst Hannum and Eileen F Babbitt (eds) Negotiating Self-Determination (Lexington Books, Lanham, 2006) 61 at 61.

228 Legal consequences of the separation of the Chagos Archipelago from Mauritius in 1965 (Advisory Opinion) [2019] General List No. 169, 25 February 2019 [Chagos Archipelago] at [144]. 
Klabbers interprets this Advisory Opinion as "nigh-on exclusively" linking self-determination to decolonisation. ${ }^{229}$ However, the ICJ is explicit in the above excerpt that self-determination has broad application and, therefore, the Court needs to limit itself to decolonisation for the purposes of that opinion. Other evidence of self-determination's wider relevance includes references made to it in cases where decolonisation was irrelevant, or at least not relevant in the contemporary settings. Notably, self-determination was central to the formation of new States from the former Yugoslavia and former Soviet Union. ${ }^{230}$ Regarding Kosovo, for example, the Independent International Commission on Kosovo concluded that its conditional independence from the Federal Republic of Yugoslavia (FRY) was the necessary means of achieving self-determination. ${ }^{231}$ This reflected a proposition (which, the Commission recognised, remains contested) ${ }^{232}$ that a State, such as FRY, can lose its sovereignty over a people, such as the Kosovars, when it subjects them to "persistent and brutal suppression of both individual rights and collective rights of self-government". ${ }^{233}$ While debate continues as to whether this "remedial secession" doctrine exists, the European Court of Human Rights nevertheless suggested in Loizidou v Turkey that such developments nevertheless indicate a trend where self-determination is applied outside decolonisation contexts: ${ }^{234}$

\footnotetext{
Until recently in international practice the right to self-determination was in practical terms identical to, and indeed restricted to, a right to decolonisation. In recent years a consensus has seemed to emerge that peoples may also exercise a right to self-determination if their human rights are consistently and flagrantly violated or if they are without representation at all or are massively under-represented in an undemocratic and discriminatory way. If this description is correct, then the right to self-determination is a tool which may be used to re-establish international standards of human rights and democracy.
}

Jan Klabbers "Shrinking Self-Determination: The Chagos Opinion of the International Court of Justice" (2019) 8(2) ESIL Reflections) at 2.

230 Raič, above n 148, at 445 and chapter 8 generally.

231 The Kosovo Report, above n 168, at 277-278. Whilst Kosovo is not a member of the United Nations, it enjoys formal statehood recognition from over 100 countries and is a member of other international organisations: Central Intelligence Agency "Kosovo" The World Factbook <www.cia.gov>.

232 For example, see Katherine Del Mar "The myth of remedial secession" in Duncan French (ed) Statehood and Self-Determination: Reconciling Tradition and Modernity in International Law (Cambridge University Press, Cambridge, 2013) 79.

233 The Kosovo Report, above n 168, at 277, and see 185-186.

234 Loizidou v Turkey (Merits) (1996) VI ECHR Reports 2216, 108 ILR, at 24 (Judge Wildhaber). 
While there may or may not be a doctrine of remedial secession, it is clear that self-determination is relevant law outside decolonisation situations.

Internal self-determination is also relevant outside decolonisation. For example, regarding the Serbian populations in Croatia and in Bosnia and Herzegovina, the Badinter Commission on Yugoslavia referred to all parties being bound by "the peremptory norms of general international law and, in particular, respect for the fundamental rights of the individual and the rights of peoples and minorities". ${ }^{235}$ Likewise, the ICJ recognised the Palestinian people's legal right to self-determination in the advisory opinion, Legal Consequences of the Construction of a Wall in the Occupied Palestinian Territory (Israeli Wall advisory opinion). ${ }^{236}$ In doing so, it was guided by the General Assembly, which had resolved to recognise the right of Palestinians to self-determination and to an independent State. ${ }^{237}$ The rule also appears in an important post-decolonisation context, that is, in the 1991 founding document of the Commonwealth, which seeks to build relations on the basis of "the inalienable right to self-determination". ${ }^{238}$ The last of the Commonwealth States to gain independence was Brunei in $1984,{ }^{239}$ so the recognition of self-determination as an inalienable right persists subsequently to decolonisation.

The importance of each of these cases is that decolonisation was irrelevant, or only relevant historically, but the right to self-determination was material. ${ }^{240}$ Translating that to the relocation scenarios of low-lying States, the lack of contemporary colonisation context is extraneous to the existence of, and the peoples' ongoing entitlement to, self-determination.

238 The Alma-Ata Declaration (21 December 1991) at preamble, second recital.

239 Nani Suryani Haji Abu Bakar "Brunei's Political Developments Between 1966 and 1984: Challenges and Difficulties over its Security and Survival" (PhD thesis, University of Leeds, 2006) at 186.

240 While some commentators refer to the circumstances in Palestine as "colonisation", the ICJ refers to multiple Security Council resolutions and a report by the Secretary-General that describe it as a "de facto annexation", and the ICJ itself says that the persistence of the wall and its associated regime "would be tantamount to de facto annexation": Israeli Wall advisory opinion, above n 168, at 139140, 181 and 184. 
Concluding that self-determination is relevant beyond decolonisation is bolstered further by the right's temporal nature, that is, that it exists in perpetuity. According to Cassese, whilst internal self-determination is an ongoing right, external self-determination for colonised peoples "ceases to exist under customary international law once it is implemented". ${ }^{241}$ However, the temporal nature of the internal and external forms of self-determination is more similar than his summary suggests. With external self-determination, key aspects may be completed with a referendum or new constitution, or alternatively with the gradual evolution of the State's systems. ${ }^{242}$ But the right of peoples to determine their place in the international community of nations must be a "constant entitlement", as Higgins describes. ${ }^{243}$ The right is not exhausted or extinguished once independent statehood is attained; it is "not as such dependent on a particular history." ${ }^{244}$ Logically, it must exist in perpetuity. The travaux préparatoires of the ICCPR supports this conclusion, revealing, as Nowak finds, that "the permanent character of the right of self-determination was emphasized, principally by use of the present tense ('have' instead of 'shall have')". ${ }^{245}$ This conclusion is also bolstered by UNGA Resolution 1803 , which states that "a basic constituent of the right of self-determination" is "permanent sovereignty over natural wealth and resources", ${ }^{246}$ not sovereignty at the point in time at which statehood status is attained. An illustration of this perpetual character is that the "inalienable right" persists as a bulwark against international wrongs, such as the threat or use of force, and interference in internal affairs. ${ }^{247}$

At 120; and see Crawford, above n 169, at 126. Renan famously opined that "a nation's existence is ... an everyday [or daily] plebiscite": Ernest Renan "What is a Nation? (Qu'est-ce Qu-une Nation?, 1882" in MFN Giglioli (editor and translator) Ernest Renan: What is a Nation? and Other Political Writings (Columbia University Press, New York 2018) 247 at 261-262.

244 Knop, above n 176, at 66.

245 Nowak, above n 171, at 12.

246 Resolution 1803, above n 161, at preamble, second recital.

247 Declaration on the Inadmissibility of Intervention in the Domestic Affairs of States and the Protection of Their Independence and Sovereignty GA Res 2131, XX, A/Res/20/2131 (1965) [Resolution 2131]. at preamble, third recital, [3] and [5]; and see Importance of universal realization of the right of peoples to self-determination and of the speedy granting of independence to colonial countries and peoples for effective guarantee and observance of human rights GA Res 2955, XXVII (1972), at preamble, third recital; and Crawford, above n 169, at 137-138. 
For existing sovereign States, internal self-determination is the routine, day-to-day, predominant expression of the right. However, internal and external self-determination both exist in perpetuity. Once statehood is created, it cannot be undone involuntarily by third-party States; something that will be examined in chapter 4. For low-lying States, the challenge is establishing how to ensure the right endures ex situ by developing various means to give effect to both external and internal aspects of the right given the marked change of circumstances. For these and other challenges, parties should assume that the relocation enterprise should facilitate and enable the peoples of low-lying States to enjoy their right to self-determination. This should permeate negotiations and agreements.

\section{Concluding on Ex Situ Entitlement to Self-Determination}

In summary, (i) the low-lying States' populations qualify as peoples, ${ }^{248}$ (ii) they currently enjoy de facto and de jure external and internal self-determination; ${ }^{249}$ (iii) the right belongs to a people, not a people in a defined territory; ${ }^{250}$ (iv) the right is not extinguished by virtue of severing territorial connection; ${ }^{251}$ (v) the right remains relevant beyond decolonisation; ${ }^{252}$ and (vi) the right exists in perpetuity. ${ }^{253}$ Given these factors, the low-lying peoples' right to self-determination should follow them to their new territory. The practical challenges in identifying who this right might be claimed against are discussed later. ${ }^{254}$

\footnotetext{
248 This Chapter, Part IV(A).

249 Part IV(A).

250 Part IV(B)(1).

$251 \quad$ Part IV(B)(1)

$252 \operatorname{Part} I V(B)(2)$.

253 Part IV(B)(2).

254 Chapter 3, Part II(B).
} 


\section{The Concurrent Emergence of Self-Determination as both Law and Duty}

The peoples of low-lying States enjoy the right to self-determination today and this should continue even in the relocation enterprise. This raises the question of what self-determination is, particularly in the relocation enterprise. Understanding this right begins by looking at its emergence in public international law and the duties associated with ensuring its enjoyment.

\section{A. The Emergence of a Duty of Assistance}

It is well established that the right to self-determination imposes obligations erga omnes and many argue it is also a jus cogens norm of international law. ${ }^{255}$ For instance, the African Union, in its submission to the ICJ for the Chagos Archipelago advisory opinion, averred: $:^{256}$

It is no longer a matter of dispute in international law, that the right of peoples to self-determination -first expressed in the nineteenth century- is a cardinal principle in modern international law, regarded as jus cogens. This erga omnes character means that the right to self-determination entails a corresponding duty on the part of all States and international organisations to enforce this right.

255 Barcelona Traction, Light and Power Company, Limited (Belgium v Spain) (Second Phase) (Judgments, Advisory Opinions and Orders) [1970] ICJ Rep 3 at 312 (Judge Ammoun); Chagos Archipelago, above n 228, at [180]; Legal consequences for States of the continued presence of South Africa in Namibia (South West Africa) Notwithstanding Security Council Resolution 276 (1970) (Advisory Opinion) [1971] ICJ Rep 16 [Namibia advisory opinion] at 31; and Western Sahara (Advisory Opinion) [1975] ICJ Rep 12 at 36; and East Timor, above n 168, at 102 (citations omitted). Regarding the jus cogens status, in particular see Legal consequences of the separation of the Chagos Archipelago from Mauritius in 1965 (Advisory Opinion) [2019] (Judge Cançado Trindade) [Chagos Archipelago (Cançado Trindade)], at [118]-[119], [115], and [129], in which Judge Cançado Trindade lists the participating Delegations (the African Union plus 17 States) whose arguments include support for self-determination being a jus cogens norm. See also commentaries: Mariano J Anzar-Gómez "The Extinction of States" in Eva Rieter and Henri de Waele Evolving Principles of International Law: Studies in Honour of Karel C. Wellens (Martinus Nijhoff Publishers, Leiden, 2012) 25 at 42; Crawford, above n 169, at 447; and Dire Tladi Third report on peremptory norms of general international law (jus cogens) by Dire Tladi, Special Rapporteur A/CN.4/714 (2018) at [62].

256 'Written Statement of the African Union' Legal Consequences of the Separation, Chagos Archipelago (Advisory Opinion) [2019] ICJ Written Proceedings, at [69]. 
Indeed, in the context of Western Sahara, the ICJ described the self-determination as "a basic assumption". 257

The right's development is well traversed by others, ${ }^{258}$ so it is unnecessary to repeat in full here. However, certain aspects of this evolution indicate how it might further develop in light of the situations of the low-lying States, particularly regarding the OHCHR's conclusion that "States have a duty to take positive action" to avert the climate threat to self-determination. ${ }^{259}$ A brief history also provides additional support for the conclusion that self-determination's relevance was not spent with the decolonisation phase; that it is not a one-time right. ${ }^{260}$

Self-determination's emergence as a rule of international law, rather than as only a political principle, began with the promulgation of the UN Charter in $1945 .{ }^{261}$ Article 1(2) provides that a purpose of the UN is "[t]o develop friendly relations among nations based

Western Sahara, above n 255, at 36.

258 For a brief history of self-determination, see Chagos Archipelago (Cançado Trindade), above n 255, at [120]-128]; East Timor, above n 168; John P Grant and J Craig Barker Encyclopadic Dictionary of International Law (3rd ed, Oxford University Press, Oxford, 2009) at 550; Thürer and Burri, above n 148, at 114-116; and Edward McWhinney Self-Determination of Peoples and Plural Ethnic States in Contemporary International Law: Failed States, Nation-building and the Alternative, Federal Option (Martinus Nijhoff Publishers, Leiden, 2007) at 1-13. For a comprehensive history of selfdetermination, see Cassese, above n 146, at 11-33; Hurst Hannum Autonomy, Sovereignty, and SelfDetermination: The Accommodation of Conflicting Rights (University of Pennsylvania Press, Philadelphia, 1990); Knop, above n 176, at 109-274; Summers, above n 120, at 83-139 and Sureda, above $\mathrm{n} 116$, generally.

OHCHR, above n 10, at [41].

260 This Chapter, Part IV(B)(2).

261 Before the Charter, self-determination was a philosophical and political concept only, albeit in important historical contexts. See "Report of the International Committee of Jurists entrusted by the Council of the League of Nations with the task of giving an advisory opinion upon the legal aspects of the Åland Islands Question" Official Journal of the League of Nations, Supplement No. 3 (October 1920) at 3; and The Åland Islands Question (On the Merits) (1921) Report by the Commission of Rapporteurs, League of Nations Council Document B7 21/68/106. The notable philosophical and political uses of self-determination include the American Declaration of Independence of 1776, the French Revolution of 1789, the Bolshevik Revolution of 1917, and Woodrow Wilson's Fourteen Points of 1918, which informed the Treaty of Peace between the Allied and Associated Powers and Germany 1919 (Treaty of Versailles) and the Covenant of the League of Nations in 1919: Woodrow Wilson, President of the United States of America "President Woodrow Wilson's Fourteen Points: 8 January 1918" (Woodrow Wilson's Fourteen Points), available at Yale Law School, The Avalon Project: Documents in Law, History and Diplomacy <avalon.law.yale.edu>, citing The Treaty of Peace between the Allied and Associated Powers and Germany (signed 28 June 1919) [Treaty of Versailles]. 
on respect for the principle of equal rights and self-determination, and to take other appropriate measures to strengthen universal peace." Article 55 then provides that the UN will promote various ideals for economic and social cooperation:

\footnotetext{
With a view to the creation of conditions of stability and well-being which are necessary for peaceful and friendly relations among nations based on respect for the principle of equal rights and self-determination of peoples.
}

With Article 56, "[a]11 Members pledge themselves to take joint and separate action in cooperation with the Organization for the achievement of the purposes set forth in Article 55", which include "promot[ing] ... universal respect for, and observance of, human rights and fundamental freedoms for all". A plain reading of Article 56 suggests Members voluntarily undertook a legal commitment to a positive obligation. ${ }^{262}$ However, many commentators argue that these direct references to self-determination did not create any binding legal principle in $1945 .{ }^{263}$ Regardless, the Charter was the seed for the binding nature that later emerged and, importantly, for the idea of "joint action".

Since the Charter's inception, there have been General Assembly Resolutions on self-determination almost every year since The right of peoples and nations to self-determination (Resolution 637) in 1952. In that Resolution, the General Assembly recommended that States "shall uphold the principle of self-determination of all peoples". ${ }^{264}$ Resolution 637 does not define the "peoples" or "self"; the substance of the right; which States specifically owe duties to which other specific States, and under which circumstances; what is "uphold"; and when will upholding be necessary. But this early Resolution furthers the development of (undefined) responsibilities of States ("shall uphold") regarding their own people's and others' ("all peoples") right to self-determination.

262 Oscar Schachter "The Charter and the Constitution: The Human Rights Provisions in American Law" (1951) 4(3) Vand L Rev 643 at 648.

263 See The Application of the United Nations Charter to Domestic Law (1951) 20(1) Fordham L Rev 91 at 94-96; Thürer and Burri, above n 148, at 115; Crawford, above n 169, at 122; and Shaw, above n 91, at $183-184$.

264 The right of peoples and nations to self-determination GA Res 637, VII (1952) [Resolution 637] at [1]. 
The next notable statement was Resolution 1514 in 1960. This provided some substance to the right, providing, "[a]ll peoples have the right to self-determination; by virtue of that right they freely determine their political status and freely pursue their economic, social and cultural development". ${ }^{265}$ Although it pertained to decolonisation, that paragraph was repeated verbatim without such limiting context as the opening articles of both the ICCPR and the International Covenant on Economic, Social and Cultural Rights (ICESCR). ${ }^{266}$ Indeed, those 1966 Covenants go further by adding both positive ("promote") and negative ("respect") duties in common article 1(3):

The State Parties to the present Covenant, including those having responsibility for the administration of Non-Self-Governing and Trust Territories, shall promote the realization of the right of self-determination, and shall respect the right, in conformity with the provisions of the Charter of the United Nations.

In 1970, the General Assembly adopted by consensus the Declaration on Principles of International Law concerning Friendly Relations and Cooperation among States in accordance with the Charter of the United Nations (Friendly Relations Declaration). ${ }^{267}$ Although non-binding, the Friendly Relations Declaration is regarded as "the most authoritative statement of the principles of international law relevant to the questions of self-determination and territorial integrity."268 This authoritative statement signals that self-determination is a legal right. Furthermore, it provides indications of the right's positive and negative obligations, and the rights-holders and duty-bearers. The Friendly Relations Declaration states: ${ }^{269}$

By virtue of the principle of equal rights and self-determination of peoples enshrined in the Charter of the United Nations, all peoples have the right freely to determine, without external interference, their political status and to pursue their economic, social and cultural

Resolution 1514, above n 208, at [2].

ICCPR, art 1(1); and ICESCR, art 1(1).

Friendly Relations Declaration, above n 226.

International Commission of Jurists The Events in East Pakistan, 1971: A Legal Study by the Secretariat of the International Commission of Jurists (Geneva, 1972) at 67; see also Shaw above $\mathrm{n}$ 91, at 185; Crawford, above n 91, at 42 and 193; and Cassese, above n 146, at 43. 1(a)(VIII). 
development, and every State has the duty to respect this right in accordance with the provisions of the Charter.

Every State has the duty to promote, through joint and separate action, realization of the principle of equal rights and self-determination of peoples, in accordance with the provisions of the Charter, and to render assistance to the United Nations in carrying out the responsibilities entrusted to it by the Charter regarding the implementation of the principle

Every State has the duty to refrain from any forcible action which deprives peoples ... of their right to self-determination and freedom and independence.

Later, in the 2001 Draft articles on Responsibility of States for Internationally Wrongful Acts (Draft articles on State Responsibility), the International Law Commission (ILC) stated that self-determination is a peremptory norm ${ }^{270}$ and there is an obligation on the international community to "permit and respect its exercise". ${ }^{271}$ Commentary from States, ${ }^{272}$ international organisations ${ }^{273}$ and legal scholars ${ }^{274}$ increasingly links these obligations to climate change impacts and low-lying States.

As the law of self-determination has evolved, elements of what it involves have become clear. It imposes obligations erga omnes and is likely to be a jus cogens norm. It is a right belonging to "all peoples" 275 to freely determine ${ }^{276}$ their political status and their economic, social and cultural development. ${ }^{277}$ It is the duty of "all States" 278 to promote, through joint and separate action, the free and genuine expression of the peoples

Draft articles on State Responsibility, above n 118, at 85 [5], 113 [5] and 114 [5].

At 113 [5].

For example, the Maldives: Muller, above n 144, at 10; and

For example, Pansieri, above n 140; and OHCHR Understanding Human Rights and Climate Change (Office of the United Nations High Commissioner for Human Rights, Submission to the 21st Conference of the Parties to the United Nations Framework Convention on Climate Change, November 2015) at 14-15.

274 For example, Maguire and McGee, above n 75; McAdam, above n 41, at 154-158; and Willcox, above n 162.

275 See this Chapter, Part IV above.

276 See Part VII(B).

277 Part VII(A)(4).

278 Chapter 3, Part II. 
concerned. It is also the duty of all States to pay regard to the will they express. ${ }^{279}$ Each of these elements will be discussed later.

\title{
B. The Imprecise Implications of Self-Determination
}

Beyond these high-level factors, "international law as it currently stands does not spell out the implications of the right to self-determination". ${ }^{280}$ Thus, whilst low-lying States can expect self-determination to be maintained, precisely what this means and how it ought to be done is currently unclear. Crawford argues, however, that this does not need to paralyse the right's potential role: ${ }^{281}$

\begin{abstract}
This implies a rather cataclysmic view of the growth and creation of international law rules: until a suggested rule has become entirely clear in principle and application, it is not a rule at all. That would constitute a powerful solvent in many areas of the law. But 'guiding juridical principles' can coexist with uncertainties as to their application in specific cases: so long as there exists a core of reasonably clear cases, the status of the principle need not be doubted.
\end{abstract}

There already exists a body of data which helps clarify the uncertainties for low-lying States, as is explored further later in this chapter and in chapter 3.

Although the lack of clarity does not necessarily impede self-determination from being useful in the climate change contexts of the low-lying States, there is a counter risk that compassion lures one into erroneously finding an expansive right. ${ }^{282}$ Outside decolonisation, political assertions of self-determination can be far-reaching and there could be endless competing claims. ${ }^{283}$ Some States may have concerns that developing

See Chapter 2, Part VII(B).

Badinter Commission on Yugoslavia, above n 235, at 1498.

Crawford, above n 169, at 123-124. A group of experts convened by UNESCO was also unperturbed by collective rights being vague, concluding that the international community is simply "embark[ing] upon a ... process in the elucidation of the rights of peoples": UNESCO, above $n$ 175, at [21].

Klabbers, above n 169, at 188-189; and Duncan French "'You Will Always Have the Poor': A Reflection on the Paradox of Justice as Law" (2015) 22 International Journal on Minority and Group Rights 533, at 539, in which French states that "there is a real risk that one can see fairness (or unfairness) in every legal rule or process."

UNESCO, above n 175, at [5] and [22]; and Hannum, above n 1, at 32. 
the law for low-lying States could create risks with particular internal or international situations involving self-determination claims. Realism must check any interpretation relating to low-lying States' situations.

These two issues - the lack of clarity and other States' concerns - may result in the international community resisting the application and development of self-determination for the low-lying States' ex situ scenarios. This is unnecessary. Their unique factual scenarios distinguish developments for their needs from other fact patterns; the law can develop for their purposes without necessarily affecting its meanings elsewhere.

The generality and imprecise shape of self-determination provides low-lying States an opportunity to proactively propose what it means for their circumstances. Equally, the credibility of their proposals will be enhanced by acknowledging other States' concerns and the need to confine developments to their relatively discrete circumstances.

\section{Strategic Elements of Self-Determination}

Developments for self-determination concerning low-lying peoples' relocation enterprises will build on the right's existing foundations. This part focuses on explaining the right's strategic elements, that is: the international community's aims in endowing the right to self-determination; how effectuating the right is generally conceptualised, distinguishing between external and internal self-determination; and how these strategic elements might apply to low-lying States' relocation enterprises. This is the first component of the framework described earlier. ${ }^{284}$ The framework differentiates between the right's strategic elements and operational elements. This part focuses on the strategic elements. The part that follows examines the operational elements, being the substantive and procedural entitlements necessary for enjoying self-determination. 


\section{A. Objectives}

Identifying the objectives of self-determination is helpful for identifying the right's operational elements later in the analysis. At an international level, the right has three objectives. The first objective, noted in the Charter and elsewhere, ${ }^{285}$ is for self-determination to be a basis for developing friendly relations among nations and strengthening universal peace. ${ }^{286}$ This is intended to work in two general ways: achieving self-determination resolves disputes by separating disputing parties (external self-determination) or creating power-sharing arrangements (internal self-determination); and an extant de jure right to self-determination, coupled with the prohibition of the threat or use of force, prevents new disputes from arising or succeeding. In practice, certain self-determination claims have been a source of conflict, particularly those relating to secessionist movements. ${ }^{287}$ However, this simplified theoretical summary serves to illustrate broadly how self-determination is intended to promote peace.

The second international objective of self-determination is to enable other human rights. The General Assembly, the Human Rights Committee and the Badinter Commission on Yugoslavia have all recognised that the enjoyment of self-determination is essential for securing individual human rights. ${ }^{288}$ Following the decolonisation period, thirteenth recital and 124; Resolution 1803, above n 161; Resolution 637, above n 264, at preamble, second recital; Resolution 1514, above n 208; and annual Resolutions titled Importance of the universal realization of the right peoples to self-determination or similar.

286 self-determination was already understood as being pivotal to international peace. Former United States President, Woodrow Wilson, did not use the term "self-determination", but the principle is implied and reflected throughout his Fourteen Points statement that was the basis for negotiating the Treaty of Versailles and the Covenant of the League of Nations: Woodrow Wilson's Fourteen Points, above $\mathrm{n}$ 261; and see Office of the Historian (US) "Milestones: 1914-1920: Wilson's Fourteen Points, 1918" Department of State < history.state.gov>.

287 See generally Marc Weller "The Self-Determination Trap" (2005) 4(1) Ethnopolitics 3; and Marc Weller and Barbara Metzger (eds) Settling Self-Determination Disputes: Complex Power-Sharing in Theory and Practice (Martinus Nijhoff, Leiden, 2008).

Resolution 637, above n 264, at preamble, first recital; Human Rights Committee General Comment No. 12: Article 1 (Right to self-determination) in Human Rights Instruments: Volume I: Compilation of General Comments and General Recommendations Adopted by Human Rights Treaty Bodies HRI/GEN/1/Rev.1 (Vol I) (2008) 172 [General Comment 12] at 183 [1]; and Badinter Commission on Yugoslavia, above n 235, at 1498. 
the role of self-determination regarding individual rights is most apparent when internal self-determination is linked to certain other human rights norms. ${ }^{289}$ For example, rights of political participation and protection of identity in turn protect, for example, rights of minorities and indigenous peoples. Such norms are manifestly jeopardised with any relocation of low-lying peoples. ${ }^{290}$

Raič proposes a third international objective, "to end the dominance of one group by another in order to protect the former's identity or 'selfness'", ${ }^{291}$ that is:.292

... the protection, preservation, strengthening and development of cultural, ethnic, and/or historical identity or individuality (the 'self') of a collectivity, that is, of a "people", and thus guaranteeing a people's freedom and existence.

How do these three international objectives of self-determination relate to the low-lying States' scenarios? Regarding peace and security, there is not a simple causal connection between climate change, migration and conflict, but there are plausible indirect links, which are intertwined with other complexities that mediate or aggravate conflict conditions. ${ }^{293}$ For example, the indirect links include adverse environmental changes that stimulate non-State terrorist actors, such as Islamic State ${ }^{294}$ for which it is reported more recruits come from the Maldives per capita than any other country. ${ }^{295}$ There is also an issue of peace for the destination community, as some commentators suggest

\section{of this Chapter.}

290 Ross, above n 140.

291 Raič, above n 148, at 444.

292 At 445.

293 Halvard Bahaug "Climate-conflict research: some reflections on the way forward" (2015) 6 WIREs Climate Change 269 at 269; Francis A Galgano "The Environment-Conflict Nexus" in Frances Galgano (ed) The Environment-Conflict Nexus: Climate Change and the Emergent National Security Landscape (Springer, Cham, CH, 2019) 1 at 1-3; and Ole Magnus Theisen, Nils Petter Gleditsch and Halvard Bahaug "Is climate change a driver of armed conflict?" (2013) 117 Climate Change 613 at 621.

294 Caitlin E Werrell and Francesco Femia "Climate Change, the Erosion of State Sovereignty, and World Order" (2016) 22(2) Brown Journal of World Affairs 221 at 231.

295 Viraj Solanki "State of emergency ends, but the Maldives is still in crisis" (3 April 2018) International Institute for Strategic Studies <www.iiss.org>. 
climate migrants are a threat. ${ }^{296}$ Barnett and Webber have found, however, that there is insufficient evidence that climate-induced migration will increase violent conflict. ${ }^{297}$

That said, challenges are likely for the relationships between the relocating and destination communities if enabling low-lying peoples' self-determination is provided for in relevant bilateral arrangements. While governments' expectations may be aligned, communities' expectations may not be. For example, a survey into attitudes towards New Zealand accepting Pacific climate migrants found New Zealanders were open to this but on the condition that the migrants "integrate into host communities' lifestyles and cultures." 298 It is beyond scope to examine here how such attitudes could be shifted but the methods for implementing relocation will influence the communities' relationships. Barnett and Webber recommend policies that: "promote mutual understanding among host and migrant populations"; 299 "foster cultural awareness[;] ... [e]nsure that migrants have the same rights and freedoms as local people"; 300 "[p]rovide adequate time for preparation[;] ... [r]ebuild the migrant community as a community[;] ... [r]espect existing decision-making structures within the [relocating] community[;] ... [and] [m]ake sure that the host region is compensated for resources lost on account of the migrants". ${ }^{301}$

Regarding the right's second international objective of enabling the other, individual human rights, climate change in general endangers all those rights. ${ }^{302}$

296 For example, see Jared Ferrie "Climate change and mass migration: a growing threat to global security" (19 January 2017) IRIN: The Inside Story on Emergencies <www.irinnews.org>.

297 Jon Barnett and Michael Webber "Accommodating Migration to Promote Adaptation to Climate Change: Background Paper to the 2010 World Development Report" (World Bank, Policy Research Working Paper 5270, April 2010) at 21. See also Elaine Kelly "Migration is a solution to climate change, not a threat to security" (21 November 2013) The Conversation <www.theconversation.com>.

298 James Allwood "How climate change displaces Pacific Island settlements and the public's perception of large scale migration" (MS Sc Thesis, University of Waikato, 2013) at 55.

299 Barnett and Webber, above n 297, at 21.

$300 \quad$ At 37.

301 At 39.

302 OHCHR Report of the Office of the United Nations High Commissioner for Human Rights on the relationship between climate change and human rights A/HRC/10/61 (2009), at [20]. The particular concerns of the Human Rights Commissioner are the rights to life, adequate food, water, health, and adequate housing: OHCHR, A/HRC/10/61 (2009), at [20]-[38] and [42]-[54]. There are also concerns for specific groups that already face vulnerabilities, including women, children and indigenous 
Those risks arise from environmental changes per se, and from (mal)adaptation and disaster response measures, including relocation. Previous experiences show prejudice and exploitation can follow people in other situations of forced migration, such as by natural disasters, development projects and conflict. ${ }^{303}$ Even in planned relocation, there are risks to human rights, such as freedom from discrimination and forced labour, participation in government, freedom of movement, and more. ${ }^{304}$ These experiences highlight the importance of active protection for low-lying islanders' human rights including self-determination, at the same time as supporting, educating and building the capacity of the welcoming communities. ${ }^{305}$

There are also the interests and human rights of destination communities at stake. Perceptions of immigration are mixed. ${ }^{306}$ However, there are perceptions that immigrants pose a range of risks, leading to "a worrying rise in discrimination, xenophobia, exclusion,

peoples: Mayesha Alam, Rukmani Bhatia and Briana Mawby Women and Climate Change: Impact and Agency in Human Rights, Security, and Economic Development (Georgetown Institute for Women, Peace and Security, 2015); Angie Dazé "Why Gender Matters in Climate Change Adaptation" (6 June 2019) International Institute for Sustainable Development <www.iisd.org>; UN WomenWatch Women, Gender Equality and Climate Change (factsheet, 2009); Joy Guillemot "Child Rights at Risk: the Case for Joint Action with Climate Change" UNICEF Office of ResearchInnocenti <www.unicef-irc.org>; and United Nations Permanent Forum on Indigenous Issues Climate change and indigenous peoples (backgrounder).

303 Anthony Oliver-Smith Resettlement Principles (submission by Kristina J Peterson of the Lowlander Center to the Executive Committee of the Warsaw International Mechanism for Loss and Damage on internal and cross-border migration, displacement and other forms of human mobility, 16 May 2016); and see CHS Alliance Core Humanitarian Standard on Quality and Accountability (CHS Alliance, Groupe URD and the Sphere Project, 2014) at 14. For example, on Australia's ongoing human rights violations of maritime arrival asylum seekers, see: Juan E Méndez Report of the Special Rapporteur on torture and other cruel, inhuman or degrading treatment or punishment A/HRC/28/68/Add.1 (2015) at [16]-[31]; Human Rights Law Centre Torture and cruel treatment in Australia: Joint NGO report to the United Nations Committee Against Torture (October 2014); and Kaldor Centre Principles for Australian Refugee Policy (Andrew and Renata Kaldor Centre for International Refugee Law, University of New South Wales, 2019).

304 Gromilova, above n 48, at 79-80; Convention Concerning Forced Labour C29, International Labour Organisation C29 (adopted 28 June 1930, entered into force 1 May 1932); and see also International Convention on the Protection of All Migrant Workers and Members of Their Families 2220 UNTS 3 (opened for signature 18 December 1990, entered into force 1 July 2003) [Convention on Migrant Workers]; and Cernea, above n 49.

305 In the relocation of Carteret Islanders, an aspect of the initiative was education for both settlers and members of the destination community: Pascoe, above n 61, at 78.

306 IOM Global Migration Indicators 2018: Insights from the Global Migration Data Portal: www.migrationdataportal.org (Global Migration Data Analysis Centre and International Organization for Migration, Berlin, 2018) at 48-49. 
and human rights violations of migrants throughout the world". ${ }^{307}$ The bases for these perceptions are largely erroneous. Empirical evidence shows that sometimes, but not always, there can be downward pressure on the job market and wages for low-skilled workers, but otherwise there are no, or very few, negative economic impacts, ${ }^{308}$ which are counterbalanced by positive economic and other impacts. ${ }^{309}$ The Global Compact for Migration recognises both "the overall benefits ... [and] the risks and challenges for individuals and communities in countries of origin, transition and destination." ${ }^{310}$ There can be little doubt that sustainably securing the self-determination and human rights of climate migrants involves ensuring the destination communities' interests and concerns are also addressed. ${ }^{311}$ It is submitted, however, that there is not a dichotomy between migrants' human rights and destination communities' human rights. Human rights are universal and policy-makers have responsibilities towards all.

Regarding the right's third objective of protecting a people's identity, this is a primary concern of low-lying peoples. ${ }^{312}$ Piecemeal relocation initiatives could, as explained earlier, ${ }^{313}$ lead to the assimilation of low-lying islanders in new, dominant societies with the concomitant impacts on language, culture, custom and other manifestations of nationhood.

The strategic role of self-determination in promoting universal peace and human rights are international law objectives of the highest order. If the peoples of low-lying States become simple minorities in partner States' communities, they will lose

Laura Thompson, Deputy Director General of the International Organization for Migration "A World on the Move: The Benefits of Migration" (Brussels, 25 September 2014).

For summaries of the literature on economic impacts of immigration on destination communities, see: Florence Jaumotte, Ksenia Koloskova and Sweta C Saxena "This is the impact of migration on productivity" (31 January 2017) World Economic Forum <www.weforum.org〉; Silvia Merler "The economic effects of migration" (16 January 2016) Bruegel <bruegel.org>; and José Luis Ferreira "The effects of immigrants in the host country" (16 December 2016) Mapping Ignorance <mappingignorance.org>.

9 IOM World Migration 2005: Costs and Benefits of International Migration (International Organization for Migration, Geneva, 2005) at 17-21.

Global Compact for Migration, above n 66, at [11].

McAdam, above $n$ 41, at 157-158.

Chapter 1, Part I and III(B).

Chapter 1, Part III(B). 
constitutional, political, administrative and social protections for their ways of life, which will hinder their abilities to "freely determine their economic, social and cultural development". In turn, this imperils their enjoyment of the individual human rights. Rights may be restricted, but such restrictions ought to be proportionate and justifiable. ${ }^{314}$ This means that, while there is potential for self-determination to be restricted, that erga omnes and potentially jus cogens right remains directly relevant to the development, implementation and monitoring of low-lying States' relocation enterprises. The next step, then, is understanding how this can happen. The following section explores the right's internal and external dimensions. Later, part VIII examines the substantive and procedural aspects of self-determination.

\section{B. External and Internal Dimensions of Self-Determination}

A common framework for comprehending the operationalisation of self-determination is distinguishing between its external and internal forms. The external form involves a people self-determining as an independent State among the community of nations. The internal form involves a people self-determining as an effective group within an existing State. While other analytical accounts of self-determination have been presented, the internal/external model is utilised here because of its broad acceptance, and for the useful insights it offers on how self-determination may be secured ex situ for low-lying peoples. ${ }^{315}$ The decision for low-lying peoples to adopt one or the other dimension has considerable strategic implications, as will become evident through this discussion.

314 Regarding different approaches to proportionality and justifying proportionality in human rights, see: Martin Luterán "The Lost Meaning of Proportionality" and TRS Allen "Democracy, Legality, Proportionality", both in Grant Huscroft, Bradley W Miller and Grégoire Webber (eds) Proportionality and the Rule of Law: Rights, Justification, Reasoning (Cambridge University Press, Cambridge, 2014) 21 and 205.

315 See Crawford, above n 169, at 107; Garner, above n 148, at 1565 and also 1522; Legal Information Institute, Cornell University Law School "Self Determination (International Law)" Wex Legal Dictionary <www.law.cornell.edu/wex>; and Franck, above n 148, at 52. An alternative to this duality view considers self-determination as an open-textured principle and a set of rules, whereby it is more responsive to factual context: Klabbers, above n 169, at 198-199. For an overview of alternative "open-textured", "multi-layered" accounts, see Willcox, above n 162, at 101-105. 
There are losses inherent in relocating low-lying peoples from their own land and maritime territories. However, several options remain for how low-lying peoples' rights to self-determination can be maintained ex situ, albeit limited by those losses. Some options involve external self-determination, others internal. They can be envisaged as a spectrum according to the extent of legal protection endowed. At one end of the spectrum is statehood. ${ }^{316}$ Down the spectrum are options for lesser international legal personalities, such as that enjoyed by the sui generis entity, the Sovereign Military Hospitaller Order of Saint John of Jerusalem, of Rhodes and of Malta (Order of Malta). Further down the spectrum are options for domestic legal personalities, including trusts and corporations, such as those established for the collective ownership and governance of indigenous peoples' assets and activities. ${ }^{317}$ Finally, at the other end of this spectrum, groups may constitute informal collectives with no legal personality. A relocated people could be represented by both an international legal person, such as a State or sui generis entity, plus a domestic legal person within the jurisdiction of the partner State, such as a trust or corporation. These and other options are analysed in more depth in chapter 5. In terms of the applicability of external or internal self-determination, this depends on the legal option, or options, chosen.

Regarding external self-determination, the low-lying States have each undergone the 'classic' decolonisation form: the Maldives, Tuvalu and Kiribati gained independence from the United Kingdom in 1965, 1978 and 1979, respectively; and the Marshall Islands gained independence from the United States of America in $1986 .{ }^{318}$ Outside decolonisation, external self-determination has become, as Raič explains, "the principal legitimation of statehood and the creation of new States". 319 Land Court Te Kooti Whenua Māori "Māori Land Trusts \& Incorporations" <www.maorilandcourt.govt.nz>. Also, in Australia, indigenous peoples' land assets are held by corporations under the Corporations (Aboriginal and Torres Strait Islander) Act 2006.

318 Central Intelligence Agency, above n 182.

319 Raič, above n 148, at 451. 
As important as it is, external self-determination is not only a right for gaining statehood, but also for its continuity. ${ }^{320}$ Moreover, maintaining statehood does not depend on the current "defined territory"321 being either preserved and habitable, nor does it require the disruption of other States' territorial integrity. ${ }^{322}$ Options exist for maintaining statehood, as will be demonstrated in chapter 5, and territory is not an essential ingredient, as will be discussed in chapter 4 . Also, a State could, theoretically, transmute into an alternative international legal personality as an exercise of self-determination; that is, external self-determination and international legal personality could be enabled in the territory of another State. ${ }^{323}$ Options to this effect are forms of external self-determination.

Internal self-determination involves a people having a special place within an existing State, which creates a special relationship with that State. This people may be the entire population, as with low-lying States' peoples, ${ }^{324}$ or a particular sub-population, for example, indigenous peoples. ${ }^{325}$ Where it applies to a sub-population, the special relationship entitles the people to some degree of autonomy from the State for determining their economic, social and cultural development. It also entitles them to "a 'right of participation' ... in the decision-making processes of [their] State." ${ }^{326}$ Where it relates to a sub-population, then internal self-determination actually applies to at least two groups in the same State: that sub-population plus the population as-a-whole. The sub-population enjoys a special relationship with the State to address historical and contemporary issues, while the general population enjoys internal self-determination via majority representation. Changed Future" in Petra Butler and Caroline Morris (eds) Small States in a Legal World (Springer, Heidelberg, 2017) 101, at 118-119.

324 This Chapter, Part IV.

325 "All indigenous peoples have the right to self-determination": UNDRIP, art 3.

326 Raič, above n 148, at 445. The substantive and procedural aspects of self-determination are discussed in the following Part, Part VII.
} 
This internal aspect of self-determination will remain relevant in the relocation enterprise whether low-lying States have international or domestic legal personality, or both. Should they enjoy international personality, relocated low-lying peoples will maintain statehood or an alternative status among the community of States, and, out of functional necessity, will also have a special relationship with the partner State, presuming that the partner State has not ceded territory and that citizens of the low-lying State enjoy freedom of movement within the partner State. Should the low-lying peoples adopt a domestic legal personality, the principle of internal self-determination should be respected by their partner States, since they are still peoples with the right to self-determination. If low-lying States' peoples have only informal collectives, such as social organisations that lack legal personality altogether, then even their right to internal self-determination may be forsaken. They might only be able to assert a right to culture, as provided for in art 27 of the ICCPR. ${ }^{327}$

A legal framework between a low-lying State and a destination State for enabling relocation will be critical for determining whether the peoples secure their right to maintain external or internal self-determination following their relocation, and for clarifying partner States' obligations with respect to the low-lying peoples' efficacy as a group. McAdam argues that internal self-determination should be respected only "[i]f whole communities relocate". ${ }^{328}$ But the completeness of the community is only part of what determines the continuance of the collective right. At some undefined point, the low-lying islanders could, in legal terms, transmute from being peoples into being minorities without a right to self-determination. ${ }^{329}$ The clearest way of preventing this or other unwanted changes, such as loss of statehood, is through legal arrangements. 


\section{Operational Elements of Self-Determination}

The objectives and the internal and external expressions of self-determination highlight the importance of the right and some of the reasons why it is desirable to secure it in a legal arrangement. But what does it mean to enjoy the right to self-determination? This part investigates the entitlements guaranteed to a people under this right, which might also be reflected in legal arrangements. It finds that there are both substantive and procedural aspects of self-determination, illustrating that it is both a right in itself and a "bundle of rights" - to borrow the metaphor from property law ${ }^{330}$ - derived from the primary right. There are also meaningful substantive prospects flowing from the procedural aspects of self-determination.

\section{A. Substantive Aspects}

Self-determination has been conceived of as a procedural norm, ${ }^{331}$ but it is submitted here that it does create substantive entitlements or expectations. This section describes four such aspects: statehood; difference; a freely-determined political status; and economic, social and cultural development.

\section{Statehood}

The first substantive result is statehood. There is no general entitlement to the creation of new States, as this would necessarily involve disrupting the territorial integrity of an existing State. That concern is guarded against by the "safeguard clause", which says that attempts to disrupt the national unity and territorial integrity of a State are incompatible with the Charter of the UN. ${ }^{332}$ However, in certain, limited circumstances, self-determination does create an entitlement to the creation of new States, which is in

330 Jane B Baron "Rescuing the Bundle-of-Rights Metaphor in Public Law" (2014) 82(1) U.Cin.L.R 57.

331 On a procedural conception of self-determination, see Klabbers, above n 169, at 205-206; and Maguire and McGee, above n 75, at 66.

332 Resolution 1514, above n 208, at [6]. See also Friendly Relations Declaration, above n 226, at preamble, fourteenth recital and 124 . 
decolonisation ${ }^{333}$ and, potentially, in situations involving remedial secession. ${ }^{334}$ In the latter situations, the theory of a qualified secession doctrine posits that a right to unilateral secession may exist where the people are denied internal self-determination, suffer extreme or widespread violation of their individual human rights, and where all attempts at securing their internal self-determination have been repudiated by the State.

More importantly for the low-lying States, and as detailed in chapter 4, statehood is also a substantive entitlement flowing from self-determination because that right is linked to the presumption of continuity of States. Once established, States are presumed to continue, even where they do not satisfy the classic Montevideo Convention indicia of statehood. Moreover, self-determination provides low-lying States with exclusive competence to determine their political statuses, including whether their extant statehood statuses continue ex situ. In summary, a substantive entitlement stemming from self-determination is the continuity of a people's extant State. This is not a mere procedural right.

\section{The right to be different}

Various international proclamations indicate three other substantive dimensions to self-determination. The first of these, and the second of the four aspects discussed here, is that the members of the group are recognised as an important collective-a peoplewith the right to self-determination. Hannum describes this neatly as the "right to be

333 This process continues. One example is Guam, which continues to work towards independence from the United States: South China Morning Post "'Anything is better than the status quo': Guam eyes end to American colonial rule" (16 July 2017) <www.scmp.com>. Another example is Bougainville, where there will be a referendum held in 2019 on independence from Papua New Guinea: UNDP Papua New Guinea "Creating partnerships crucial in lead up to independence referendum" (press release, 7 April 2018).

334 Reference re Secession of Quebec [1998] 2 SCR 217, at [126]; Raič, above n 148, at 447; and John Duggard and David Raič "The role of recognition in the law and practice of statehood" in Marcelo G Kohen (ed) Secession: International Law Perspectives (Cambridge University Press, Cambridge 2006) 94 at 106 and 109. See also Gentian Zyberi "Self-Determination through the Lens of the International Court of Justice" (2009) NILR 429 at 447. Note that the practice evidencing the existence of this doctrine is unclear: Jure Vidmar "Remedial Secession in International Law: Theory and (Lack of) Practice" (2010) 6(1) St Antony's International Review 37. 
different". ${ }^{335}$ The ICCPR requires States to "promote" and "respect" self-determination, and these obligations can only be fulfilled if States first acknowledge the existence of a people. Such acknowledgement is a crucial substantive result since, if this threshold is not met, the group might only be a minority and, as explained in earlier, the difference in law is significant. ${ }^{336}$ This difference is highlighted, too, in Raič's analysis, where he finds that the procedural elements of self-determination are necessarily employed regarding "matters which directly or indirectly may affect the distinct character of the people concerned". ${ }^{337}$ Overall, low-lying peoples ought to enjoy the substantive entitlement of being identified as a people. This will rely, in part, on their continual assertion of that fact. If successful, their uniqueness must be promoted and respected as a central, substantive element of "the realization of the right". ${ }^{338}$

\section{A freely-determined political status}

The third substantive aspect of self-determination is the peoples' political status, determined freely, as provided for in the 1966 Covenants. ${ }^{339}$ Having any political status is itself a substantive result, regardless of form. And there are several options available for low-lying peoples ex situ, ${ }^{340}$ including statehood itself. As will be argued later, ${ }^{341}$ States' continuity is presumed under the law of statehood and, therefore, permissible even ex situ to their current territory. Thus, in accordance with self-determination, it remains open to low-lying peoples to determine-freely and without external interference ${ }^{342}$ whether their statehood continues in the relocation enterprise or is changed to an alternative political status. At a practical level, they need to identify a third-party State being reflected in governmental institutions: Ian Brownlie "The Rights of Peoples in Modern International Law" (1985) 19(2) Bulletin of the Australian Society of Legal Philosophy 104 at 107108.

336 This Chapter, Part IV(A).

337 Raič, above n 148, at 445.

338 ICCPR, art 1(3); and see ICESCR, art 1(3).

339 ICCPR, art 1(1); and ICESCR, art 1(1).

340 Chapter 5, Part II.

341 Chapter 4, particularly Parts IV-VI.

342 This procedural aspect of self-determination is discussed in Part VII(B) of this Chapter, including its relationship to substantive matters. 
that will become a partner and recognise this legal personality in a bilateral treaty regarding the relocation enterprise. ${ }^{343}$ Nevertheless, this substantive element of self-determination means that there is a sound basis in international law to stop political messages from low-lying States' representatives about their sovereignty being at risk. ${ }^{344}$ Their narratives can instead be that low-lying peoples continue to have a right to self-determination, which entitles them to freely determine whether their States continue as part of the relocation enterprise.

It may be contended that the right to freely determine a political status is a procedural entitlement; not a substantive one. States' obligations are to "promote the realization" ${ }^{345}$ of self-determination, and this may be a long-term project. Regardless, this entitlement anticipates the milestone whereby a political status is, in fact, realised. For example, in decolonisation, self-determination frequently resulted in statehood. ${ }^{346}$ Therefore, a freely determined political status, of whatever form, is a substantive entitlement of self-determination.

\section{Economic, social and cultural development}

The final substantive outcomes, derived from art 1 of the 1966 Covenants, are the peoples' economic, social and cultural development. Related to this is "the sovereign right of every State to dispose of its wealth and natural resources". ${ }^{347}$ The General Assembly

343 See Chapter 3, Parts II(C)(3) and IV.

344 For example, Office of the President of Kiribati, above n 108.

345 ICCPR, art 1(3); and ICESCR, art 1(3).

346 Independence is not always the result of self-determination in the decolonisation context. For example, in exercising their right to self-determination, two referenda in Tokelau failed to secure the necessary two-thirds majority for the nation to become "a self-governing state in Free Association with New Zealand" so it remains part of the territory of New Zealand: Kelihiano Kalolo "Tokelau" in Stephen Levine (ed) Pacific Ways: Government and Politics in the Pacific Islands (2nd ed, Victoria University Press, Wellington, 2016) 325 at 329.

347 Resolution 1803, above n 161, at [1], referring also to Integrated economic development and commercial agreements GA Res 523 (VI) (1952) at preamble, first recital; Right to exploit freely natural wealth and resources GA Res 626 (VII) (1952) at [1]; and Recommendations concerning international respect for the right of peoples and nations to self-determination GA Res 1314 (XIII) (1958) at preamble, first recital. See also ICCPR, arts 1(2) and 47; ICESCR, arts 1(2) and 25; Report of the United Nations Conference on Environment and Development (Rio de Janeiro, 3-14 June 1992) 
recognises "the status of permanent sovereignty over natural wealth and resources as a basic constituent of the right to self-determination". ${ }^{348}$ Again, this entitlement may be interpreted as only procedural, since economic, social and cultural development are also long-term, ongoing projects. However, a substantive aspect can be induced from the fact that, as Banai correctly observes, the corollary of the right to manage natural resources is the right to make decisions about related economic and social consequences. ${ }^{349}$ Moreover, such decisions can reflect a people's right to be different and their ways of doing things. All such consequences are substantive outcomes expected from this entitlement and, therefore, should be reflected in low-lying States' relocation programmes.

The outcomes expected to be realised from self-determination's substantive entitlements are only described in broad terms, which may be an argument against there being any substantive aspect. These general elements, however, start to build a framework for low-lying States' relocation programmes; a framework which aspires to enable their self-determination. Then, in practice, the particulars of these substantive matters might be garnered from conducting the procedural aspects of self-determination.

\section{B. Procedural Aspects}

As well as the substantive entitlements regarding certain ends, self-determination is also the right of peoples to various procedural entitlements. These were initially set out by the General Assembly in Resolution 637. It was concluded that Member States with responsibilities for non-self-governing and trust territories had positive obligations to "promote", "take practical steps" and "facilitate the exercise of this right". ${ }^{350}$ Later, in

A/Conf.151/26 (Vol 1) (1992) Annex I: Rio Declaration on Environment and Development, at Principle 2; and Transforming our world: the 2030 Agenda for Sustainable Development GA Res A/Res/70/1 (2015) [Sustainable Development Goals] at [18].

348 Resolution 1803, above n 161, at preamble, second recital. See also Resolution, above n 347, at [1].

349 Ayelet Banai "Self-Determination and Resource Rights: In Defence of Territorial Jurisdiction Over Natural Resources" (2016) 22(1) Res Publica 9 at 12. Banai notes that this right is qualified: "Politics do not require at all times full and exclusive control over each and every raw material in their territory to uphold meaningful self-determination": at 10.

350 Resolution 637, above $\mathrm{n} 264$, at [2]-[3]. 
Resolution 1514, the General Assembly referred to the "exercise" of sovereignty. ${ }^{351}$ Along with these ill-defined duties owed by States, the respective peoples have general correlative entitlements regarding decision-making autonomy, which are set out in the Friendly Relations Declaration: ${ }^{352}$

\footnotetext{
... all peoples have the right freely to determine, without external interference, their political status and to pursue their economic, social and cultural development, and every State has the duty to respect this right in accordance with the provisions of the Charter.
}

This is reflected and reinforced in case law. In the Western Sahara advisory opinion, the ICJ stated that "the application of the right of self-determination requires a free and genuine expression of the will of the peoples concerned". ${ }^{353}$ The reciprocal obligation on States is their "need to pay regard to the freely expressed will of peoples". ${ }^{354}$

\section{Peaceful Procedures}

Even accounting for the extra details in the Friendly Relations Declaration and Western Sahara, the verbs used to describe procedural entitlements of self-determination remain vague. However, at least three classes of peaceful procedures have been employed: elections; plebiscites or referenda; and consultation and commissions of inquiry. These methods could be employed prior to embarking on a relocation enterprise to ascertain the people's preferred forms and means by which their self-determination may be protected. The outcomes of these processes would provide the low-lying State's agents with a legitimate mandate for negotiating with potential partner States.

\footnotetext{
351 Resolution 1514, above n 208, at preamble, eleventh recital.

352 Friendly Relations Declaration, above n 226 (emphasis added).

353 Western Sahara, above n 255, at 31.

354 At 33.
} 
a) Elections

First, general elections may relate to self-determination. ${ }^{355}$ Arguably, any general election is an expression of internal self-determination. Elections can also relate to external self-determination, as in the case of pro-independence parties forming Government in Catalonia and, in 2017, declaring independence from Spain. ${ }^{356}$ That situation may have been illegal under international law $^{357}$ and domestic Spanish law. ${ }^{358}$ However, in other situations, the UN has considered elections as valid means through which peoples can exercise self-determination, particularly where there were concerns that a sitting government was a puppet of a former colony. ${ }^{359}$

\section{b) Plebiscites or referenda}

Secondly, peoples may use plebiscites or referenda. For example, a referendum was held in 2011 regarding the independence of South Sudan, which became a member of the UN later that year. ${ }^{360}$ Also, Tokelau has held two referenda on independence from New Zealand, but the requisite two-thirds majority was not reached on either occasion ${ }^{361}$ (although self-government remains the aspiration). ${ }^{362}$

c) Consultation and commissions of inquiry

A third peaceful process relevant to self-determination is general consultation with regards to "everyday" policies and programmes administered by the executive organs of 2017).

357 Ostensibly, at least, it goes against the safeguard clause, discussed in Part VII(A)(1) of this Chapter.

358 Paul Day "Spain prosecutor seeks long jail terms for Catalan pro-independence leaders" (2 November 2018) Reuters <www.reuters.com>.

359 Sureda, above n 116, at 303.

360 United Nations "UN welcomes South Sudan as 193rd Member State" (press release, 14 July 2011).

$361 \quad$ Kalolo, above n 346, at 329.

362 Ministry of Foreign Affairs and Trade (NZ) "UNGA73: Special Political and Decolonisation Committee (Fourth Committee): statement on the question of Tokelau delivered by New Zealand" (United Nations, New York, 12 October 2018), available at <www.mfat.govt.nz〉. 
governments. Ultimately, the ordinary policy-making functions of government relate to their constituencies' economic, social and cultural development. ${ }^{363}$ These processes can also be used in relation to legal status. For example, Kiribati's independence pathway involved a consultation and advisory process to ensure the new State and the governmental powers reflected I-Kiribati values and wishes. ${ }^{364}$

Consultation processes may involve, or be preceded by, public inquiries. The UN has previously established commissions of inquiry to ascertain "the wishes and the best means of promoting the welfare" of the relevant peoples. ${ }^{365}$ These were followed by other steps, such as plebiscites. ${ }^{366}$ Countries have adopted similar processes to those employed by the UN. For example, a Bougainville Constitutional Commission was established by the Bougainville Interim Provincial Government. ${ }^{367}$

Reflecting on all of these peaceful procedures, peoples have the right to freely determine certain matters, and their States have a range of means of enabling that decision-making. Critically, the procedural entitlements have the potential to elicit the particulars of the substantive aspects of self-determination described earlier. Low-lying States must facilitate processes for their peoples to freely determine and freely pursue integral foundations of nationhood: their political status, and their economic, social and cultural wellbeing, including their use of natural wealth and resources. States also "need to pay regard to the freely expressed will of peoples". ${ }^{368}$ In terms of relocation enterprises, "self-determination means that people have the right to make decisions regarding adaptation strategies [and] about when, how, where, and if relocation occurs". 369

363 ICCPR, art 1(1); and ICESCR, art 1(1).

364 Howard Van Trease "From Colony to Independence" in Howard Van Trease (ed) Atoll Politics: The Republic of Kiribati (Macmillan Brown Centre for Pacific Studies University of Canterbury and Institute of Pacific Studies University of the South Pacific, 1993) 3 at 11-13.

365 Resolution 289, IV(C), above n 381, at [1].

366 Sureda, above n 116, at 294-295.

367 Constitution of the Independent State of Papua New Guinea, Constitutional Amendment No. 23 Peace-Building in Bougainville - Autonomous Bougainville Government and Bougainville Referendum (2002), s 281(1).

368 Western Sahara, above n 255, at 33.

369 Robin Bronen "Climate-induced community relocations: using integrated social-ecological assessments to foster adaptation and resilience" (2015) 20(3) Ecology and Society 36 at 40. 
However, when that relocation involves crossing an international border, complications arise insofar as the destination State is sovereign and is not bound by the outcomes of any peaceful procedures undertaken in low-lying States. ${ }^{370}$ Such complications will be looked at further when examining third-party States' duties in the next chapter.

\section{Democratic decision-making and governance}

Self-determination's procedural aspects, including the peaceful procedures, link it to democratic decision-making and governance. In relation to internal self-determination, Franck explains: $:^{371}$

\footnotetext{
Self-determination postulates the right of a people organized in an established territory to determine its collective political destiny in a democratic fashion and is therefore at the core of the democratic entitlement.
}

Consistent with this, Shaw surveyed the work of the Human Rights Committee and found that self-determination: $:^{372}$

\footnotetext{
... encourages states parties to provide ... details about participation in social and political structures, and [asks] how the people of the state concerned participate in the governance of their state.
}

This was evident, too, in the emergence of the Republic of Georgia; an example of external self-determination. Recognition of Georgia by the United States and member States of the European Community was relative to the EC Guidelines on the Recognition of new States in Eastern Europe and the Soviet Union, which confirmed the principle of self-determination and required respect for democracy. ${ }^{373}$

\footnotetext{
370 Hannum, above $\mathrm{n} 1$, at 41.

371 Franck, above n 148, at 52. See also Cassese, above n 146, at 302-312.

372 Shaw above n 91, at 212. See also Franck, above n 148.

373 Declaration on the "Guidelines on the Recognition of New States in Eastern Europe and in the Soviet Union" (1992) 31 ILM 1485; and Raič, above n 148, at 404.
} 
Linking self-determination and democracy does not regulate the modes of democratic governance nor, in regards to internal self-determination, regulate how power is distributed among governance units, ${ }^{374}$ such as national and sub-national governments. It does, however, create another link between the collective right to certain individual rights. Nowak explains that: ${ }^{375}$

\footnotetext{
The right of internal self-determination is based on a democratic element, which is to be exercised together with the Covenant's [ICCPR's] other political rights and freedoms, especially Arts. 19, 21, 22 and 25.
}

Article 19 gives everyone the right to hold opinions without interference, and to freedom of expression, including the "freedom to seek, receive and impart information and ideas of all kinds". Article 21 gives everyone the right of peaceful assembly. Article 22 provides for the right to freedom of association with others. And art 25 seeks to ensure every citizen's right and opportunity:

\footnotetext{
(a) To take part in the conduct of public affairs, directly or through freely chosen representatives;

(b) To vote and to be elected ... ; [and]

(c) To have access, on general terms of equality, to public service".
}

As these individual rights suggest, democratic decision-making processes can involve many activities, for example: public consultation, engagement, and participation; data gathering and sharing; policy development; and elections. Such processes are shaped by the people and institutions that administer them, and by the principles against which they operate, such as equality, transparency and collaboration. Depending, then, on the processes employed, democratic decision-making can enable a people to "lead its own distinctive common life, to express its constitutive values through its own social practices

\footnotetext{
374 Cassese, above n 146, at 332.

375 Nowak, above n 171, at 24. See also Cassese, above n 146, at 302-306, particularly the statements of UK and German representatives to the UN General Assembly at 302 and 305.
} 
and cultural forms". ${ }^{376}$ This distinctive character can be "reflected in the institutions of government under which it lives," 377 and internal self-determination can thereby affect the State's internal political structures. ${ }^{378}$

For low-lying peoples in relocation enterprises, democratic processes will be essential for fulfilling the procedural entitlements of self-determination. Such processes will be particularly important for eliciting the peoples' preferences on key aspects of their relocation: whether and where to relocate; and how their ways of life-te katei ni Kiribati and tии то аgапи Tuvalu, for instance ${ }^{379}$ — might be protected from the tyranny of the majority in a new territory.

Although democratic processes are often procedural means for expressing internal self-determination, they may also be deployed for external self-determination questions. In the decolonisation context, the General Assembly has decided that one of the factors indicative of the attainment of independence is "[t]he opinion of the population of the Territory, freely expressed by informed and democratic processes, as to the status, or change in status which they desire." ${ }^{380}$ From the earliest period of decolonisation, the UN was employing or encouraging the use of plebiscites, commissions of inquiry, or elections to establish the public's views on independence questions, including the terms and conditions of that status, ${ }^{381}$ as discussed above. Low-lying States could, therefore,

376 Allan E Buchanan "The Right to Self-Determination: Analytical and Moral Foundations" (1991) 8(2) Ariz J Int'l Comp L 41 at 46.

377 Brownlie went as far as to suggest that defining a "peoples" was derived from such ideas: "This core [of certainty about what comprises a peoples" is the right of a community which has a distinct character to have this character reflected in the institutions of government under which it lives": Brownlie, above n 335, at 107-108.

378 Raič, above n 148, at 451.

379 Pacific island nations have terms that describe collectively their values, customs and norms; way of life. For I-Kiribati, this is te katei ni Kiribati: Alaima Talu and others Kiribati: Aspects of History (University of the South Pacific and Ministry of Education Kiribati, 1979) at 121-122. For Tuvaluans, this is tuu mo aganu Tuvalu: David Stanley Moon Handbooks: South Pacific (8th ed, Avalon Travel Publishing, Berkeley CA, 1999) at 553.

380 Factors which should be taken into account in deciding whether a Territory is or is not a Territory whose people have not yet attained a full measure of self-government GA Res 742, VIII (1953), Annex, at Second part, A(1).

381 Sureda, above n 116, at 294-295, 297 and 303, citing Question of the disposal of the former Italian colonies GA Res 289, IV(C) (1949) [Resolution 289, IV(C)] at [2(a)]; and Special Report of the United 
conduct commissions of inquiry, hold referenda, or perhaps both, on the question of legal status, ${ }^{382}$ as occurred in the cases of Kiribati and Georgia.

\section{Some degree of autonomy}

The peaceful procedures and democratic decision-making are consistent with the idea that self-determination involves at least some degree of autonomy. The General Assembly described democratic processes used in decolonisation as reflecting the relevant peoples' "passionate yearning for freedom". ${ }^{383}$ It is axiomatic that self-government, if opted for, achieved and maintained, is the strongest way of fulfilling all other aspects of self-determination. Indeed, in a decolonisation context, the ICJ explained in the Namibia advisory opinion that limited autonomy may not satisfy this right: $:^{384}$

The representative of South Africa ... concluded that in the case of South West Africa self-determination 'may well find itself practically restricted to some kind of autonomy and local self-government within a larger arrangement of co-operation' (hearing of 15 March 1971). This in effect means a denial of self-determination envisaged in the Charter of the United Nations.

While self-determination may be enjoyed without self-government, such as via internal self-determination, the ICJ's conclusion highlights that effectuating the "right to be different" demands a high degree of autonomy. Rosas agrees, concluding: $:^{385}$

Nations Visiting Mission to the Trust Territories of Togoland under British Administration and Togoland under French Administration, 1955 UN Doc T/1218 (1955) at [103].

382 Using such mechanisms for State-level decisions has precedent. When Estonia reasserted its independence from Soviet occupation, a non-binding referendum was conducted asking, "Do you want the restoration of State sovereignty and independence of the Republic of Estonia?" The efficacy of this step was supported by a number of other legal manoeuvres before and after occupation: Ineta Ziemele State Continuity and Nationality: The Baltic States and Russia: Past, Present and Future as Defined by International Law (Martinus Nijhoff Publishers, Leiden, 2005) at 29.

383 Resolution 1514, above n 208, at preamble, third recital.

384 Namibia advisory opinion, above n 255, at 63.

385 Allan Rosas "The Right of Self-Determination" in Asbjørn Eide, Catarina Krause and Allan Rosas (eds) Economic, Social and Cultural Rights (2nd revised ed, Martinus Nijhoff Publishers, Dordrecht, 2001) 111 at 115. 
The right of peoples to freely pursue their economic, social and cultural development means a right of non-interference and ... a certain basic freedom to economic, social and cultural activities independent of government policies.

Nine's interpretation of self-government (from an applied philosophy perspective) includes enabling the self-determining peoples to legitimately establish justice among themselves, that is, to establish, adjudicate and enforce the group's own norms. ${ }^{386}$ Whilst, as Higgins notes, "[a]utonomy is not, of course, independence", ${ }^{387}$ in practice, it requires a level of independence from other political units, ${ }^{388}$ and from non-consensual domination of the group's values and practices by others. ${ }^{389}$ These characteristics are necessary to empower the peoples to "freely determine their political status and to freely pursue their economic, social and cultural development", as per common art 1(1) of the 1966 Covenants.

It follows that, when there are two or more peoples sharing a geographic area, the enjoyment of their respective rights to self-determination implies some degree of dovetailing of normative and legal systems. Legal pluralism is notoriously difficult to achieve, as illustrated by indigenous laws being subordinated to government-made laws where there is conflict. ${ }^{390}$ However, there is potential for relationships between legal and normative systems that are deliberate, and involve integration and other formal interactions. ${ }^{391}$

Self-determination's requirement for a level of autonomy, and the potential for dovetailing normative systems and power-sharing arrangements, reflect the international community's expectation that self-determination enables peoples to act as their own

\footnotetext{
386 Nine, above n 18 , at 362.

387 Higgins, above n 128, at 125.

388 Nine, above n 18, at 362.

389 At 46-47; and see Ödalen, above n 139, at 230.

390 See generally Shaunnagh Dorsett and Shaun McVeigh "Section 223 and the shape of native title: The limits of jurisdictional thinking" in Lisa Ford and Tim Rowse (eds) Between Indigenous and Settler Governance (Routledge, Abingdon, 2013) 162; and Nicole Roughan "The Association of State and Indigenous Law: A Case Study in 'Legal Association"' (2009) 59 UTLJ 135.
}

391 Roughan, above n 390, at 136. 
decision-makers. The Friendly Relations Declaration says self-determination processes should occur "without external interference". ${ }^{392}$ Ownership of the process may rightly be considered a substantive aspect of self-determination since, if others owned the process, that would be others'-determination, not self-determination.

However, the requirement seems not to be for absolute ownership of the process, nor absolute autonomy, nor absolutely without interference. Any such procedures must comply with norms of international law. For example, the ICJ found that declarations of independence were unlawful when connected with illegitimate use of force or other violations of peremptory norms. ${ }^{393}$ Furthermore, any processes for securing low-lying peoples' relocation, let alone ex situ self-determination, require effective relationships with destination communities and governments. Fiji's guidelines for internal climate migration reflect this, requiring: 394

... the involvement and continuous engagement of communities in the planned relocation process, especially in decision-making, site selection, the development and implementation of the relocation plan and in the post relocation monitoring.

The need for effective relationships is also reflected in the New Zealand action plan for climate migration, which involves facilitating a regional dialogue and domestic consultation. ${ }^{395}$ Nonetheless, while such constructive relationships are functionally important, self-determination still requires a meaningful degree of autonomy.

A possible limit to a people's autonomy and ownership of self-determination processes is the interpretation of "freely determine" in common art 1(1) of the 1966 Covenants. According to Nowak, "independence under international law does not mean that the affected peoples themselves truly determine their political, economic, social and

\footnotetext{
392 Friendly Relations Declaration, above n 226.

393 Kosovo Independence advisory opinion, above n 210, at 437-438.

394 Ministry of Economy (FJ), above n 46, at 9.

395 CAB-18-MIN-0218, above n 90, at [24(II)].
} 
cultural development." ${ }^{396}$ If so, then the issue is, how free is "free" ${ }^{397}$ Should the peoples' views always prevail? If a low-lying people is recognised as a people in another State, ${ }^{398}$ that State has a duty to promote and respect their self-determination. ${ }^{399}$ However, a wide spectrum of methods is available for enabling that right.

These methods will be considered further in chapter 5, but it is important to highlight here how these methods relate to the "freely determine" aspects and, therefore, the relevant strategic decisions low-lying peoples have ahead. At the conservative end of the spectrum, autonomous decision-making might be that low-lying peoples rely only on the partner State's existing systems of democratic representation and minority protection, as if they were simply migrants. For example, Fiji's constitution protects the right to equality and freedom from discrimination, ${ }^{400}$ and so does New Zealand's Bill of Rights, which also defines minorities' rights. ${ }^{401}$ While such systems are critical baselines, relying solely on generalised democratic processes will expose the low-lying people's members to the tyranny of the majority, even those in functioning, stable, liberal democracies. ${ }^{402}$ In this approach, the long-term maintenance of nationhood would rely on the people's own sustained abilities to preserve and promote their identity as a people. This is not to suggest that manifestations of nationhood, such as culture or language, are fixed or should remain so, nor that a group who are a minority in number lack the capacity to maintain their identity as a people, as colonised indigenous populations illustrate frequently. However, it is critical to recognise the risks to national identity when pressures are systemic, cultural and long-term. A worst-case scenario for relying on existing governmental systems may be where failures to provide adequate assistance and protection allow systematic human rights violations. Such abuses have been seen where rural people migrate to urban areas to escape, for example, climate change-related Klabbers, above n 169, at 194.

398 This Chapter, Part IV(A).

399 Chapter 3, Part VII.

400 Constitution of the Republic of Fiji 2013, s 26.

401 New Zealand Bill of Rights Act 1990, ss 19-20.

402 Chapter 1, Part III(B). 
drought, or salinisation of water and soil. Outcomes vary, but rural-to-urban migration has, for example, exposed women and children to distress and trauma, financial stress, abandonment by husbands and families, abuse, violence and exploitation. ${ }^{403}$ These risks emphasise the need for relocation processes to be underpinned by, among other things, the right to self-determination, which is the foundation for all other human rights. ${ }^{404}$

Moving slightly away from that conservative end of the "freely determine" spectrum, a minimum standard for internal self-determination would be consulting low-lying peoples regarding their relocations. Predictably, consultations already conducted show that people of low-lying States have clear ideas about adapting to climate change, including planned relocation. ${ }^{405}$ Further consultations would likely be conducted by each low-lying State, perhaps with the support of relevant international and regional organisations, the partner State, or civil society organisations. Alternatively, it may be led by an organisation set up to facilitate the relocation. For example, Tulele Peisa Inc is a non-government organisation established by and for the Tulun people of the Carteret

UN Women Climate Change and Migration in Bangladesh: A Gender Perspective (2015) at 23-24 and 31-32; Manipadma Jena "As climate threats drive migration, Indian women find opportunities" (18 October 2018) Reuters <www.reuters.com>; and Farida Abubakari "Why Migration is a Legitimate Form of Adaptation to Climate Change in Ghana" (31 October 2015) Modern Ghana <www.modernghana.com>. On the effects of climate change on Ghana, see: Frederick A Armah and others "Food security and climate change in drought-sensitive savanna zones of Ghana" (2011) 16(3) Migration and Adaptation Strategies for Global Change 291; and Richard Black, Dominic Kniveton and Kerstin Schmidt-Verkerk "Migration and Climate Change: Toward an Integrated Assessment of Sensitivity" in Thomas Faist and Jeanette Schade (eds) Disentangling Migration and Climate Change: Methodologies, Political Discourses and Human Rights (Springer, Heidelberg, 2013) 29.

This Chapter, Part VI(A).

The Nansen Initiative Human Mobility, Natural Disasters and Climate Change in the Pacific: Summary of Conclusions: Nansen Initiative Pacific Regional Consultation: Rarotonga, Cook Islands, 21-24 May 2013 (The Nansen Initiative, Geneva, 2013) at 5-6. The Nansen Initiative, which is funded primarily by the Governments of Norway and Switzerland, was a consultation process aiming to build consensus on a protection agenda for addressing the needs of people displaced across borders by disasters and climate change. See The Nansen Initiative <www.nanseninitiative.org $>$. A central output from Initiative has been its "Protection Agenda": The Nansen Initiative Agenda for the Protection of Cross-Border Displaced Persons in the Context of Disasters and Climate Change (December 2015) [Protection Agenda]. It has since been succeeded by the Platform on Disaster Displacement, which seeks to implement the recommendations in the Protection Agenda: Platform on Disaster Displacement <www.disasterdisplacement.org>. 
Islanders. It works closely with community members to facilitate their relocation or, for those who are not moving, in situ adaptation. ${ }^{406}$

The extent to which the peoples' "freely determined" wishes are implemented will no doubt be affected by the competing demands on, and realpolitik of, the partner State. However, processes set up to facilitate relocation should be informed and underpinned by the low-lying peoples' right to self-determination and all that it entails. In turn, and as Nowak has highlighted, those processes ought to be exercised with the political rights and freedoms in arts 19, 21, 22 and 25 of the ICCPR. ${ }^{407}$

Procedural rights do not guarantee substantive outcomes that reflect the expressed will of the peoples. However, the peoples' will, expressed freely and "without external interference", must be given serious consideration. States must promote, take practical steps and facilitate the exercise of self-determination. Together, these rights and duties anticipate the peoples enjoying some degree of autonomy and democratic processes. In turn, these processes relate to the peoples' political status, and their economic, social and cultural development. There will likely need to be a dovetailing of these decisionmaking systems with those systems that belong to the destination communities.

\section{Concluding on Procedural and Substantive Aspects}

If self-determination was deemed only as a procedural right, a duty-bearing State could fulfil obligations to ensure the free will of low-lying peoples is expressed and considered, but give those wishes little or no effect. However, whilst recent practice has focused primarily on procedural rights, self-determination still contains important substantive aspects. Similarly, recent practice has also focused on internal self-determination subsequent to decolonisation, but low-lying States have no reason in law to limit themselves in this way. As States themselves, a wide range of substantive

\footnotetext{
406 Ursula Rakova "Tulele Peisa Inc: Where are we?" (presentation to the workshop Readying the Wakas: New Zealand's Response to Climate Change-Induced Displacement in the Pacific, Wellington, October 2018).

407 Nowak, above n 171, at 24.
} 
outcomes from self-determination remain possible, relating especially to their being distinct peoples, their political status, their political, economic, social and cultural development, and their exploitation of natural resources. Further, they are entitled to be their own decision-makers, subject to international law. When decisions need to be shared with their partner State, low-lying States will continue to be entitled to rely upon self-determination's procedural aspects for addressing, inter alia, the right's substantive aspects.

The substantive and procedural means for low-lying peoples' ongoing enjoyment of self-determination can be protected in some form of legal agreement, particularly one which addresses key subjects, such as legal personality and land. ${ }^{408}$ Experience repeatedly demonstrates that the absence of principled, considered and justiciable processes creates significant problems for affected people. ${ }^{409}$ The extent and efficacy of risk abatement will be causally related to the extent to which rights can be secured, and the level of support afforded for the relocation processes and the ongoing implementation of decisions duly made. ${ }^{410}$ This, in turn, requires identifying the duty-bearers and the nature of their obligations.

408 Chapter 5.

409 See Michael M Cernea and Chris McDowell (eds) Risks and Reconstruction: Experiences of Resettlers and Refugees (The World Bank, Washington DC, 2000); John R Campbell, Michael Goldsmith and Kanyathu Koshy Community Relocation as an Option for Adaptation to the Effects of Climate Change and Climate Vulnerability in Pacific Island Countries (PICs) (Asia-Pacific Network for Global Change Research. 2005); Sachithanandam Sathananthan "External Self Determination, Internal DeColonisation and Conflict Prevention" (paper presented at the Seminar on Self-determination and Conflict Prevention Sponsored by Centre UNESCO de Catalunya and the UNESCO Etxea UNESCO Centre of the Basque Country Palais des Nations, Geneva, March 1999); and Ross, above n 140.

410 The experiences of indigenous peoples repeatedly demonstrate that the risks are still very significant. For a case study of New Zealand Māori, who are entitled to autonomy and self-determination (tino rangatiratanga) under international treaty, see Richard S Hill "New Zealand Maori: The Quest for Indigenous Autonomy" (2016) 15(1) Ethnopolitics 144. 


\section{Conclusions}

The right to self-determination is arguably jus cogens and respect for it is an obligation erga omnes. It applies to "all peoples", and the communities of low-lying States are undoubtedly "peoples", not minorities. Self-determination's relevance is not limited to decolonisation, nor to particular territories. Considering these conclusions together in the climate relocation scenario, the I-Kiribati, Maldivians, Marshallese, Tuvaluans, and any other population of wholly-affected low-lying States each have the right to self-determination in international law.

To understand the substance of this enigmatic right, this thesis proposes a conceptual framework. One aspect is self-determination's strategic elements, including its objectives, and its internal and external expressions. The right's objectives are to promote universal peace and security, and other human rights. Classically, these objectives are effectuated through external self-determination or internal self-determination, that is, carving out a special place among the international community or within the State.

The second aspect of the conceptual framework is self-determination's operational aspects, which contain a bundle of derivative rights, both substantive and procedural. The substantive entitlements are to statehood, difference, a freely-determined political status, and economic, social and cultural development. The procedural entitlements revolve around the peoples being free to determine, without external interference, those substantive aspects. In practical terms, procedural aspects involve the peoples having a meaningful degree of political, administrative and social autonomy, plus democratic decision-making within the group. In the relocation enterprise, it will also require deliberate means of dovetailing the low-lying peoples' and the destination communities' normative systems. 
Bronen has observed that "[t]he right of self-determination is the most important human rights principle to guide climate change adaptation." ${ }^{411}$ This is especially true where entire peoples are forcibly relocated and face particular and substantial risks. ${ }^{412}$ Therefore, self-determination should underpin any agreement designed to facilitate low-lying peoples' relocation, such as a bilateral or sub-regional treaty, so as to ensure that relocation is genuinely country-led. ${ }^{413}$ 


\section{Chapter 3: Duty-Bearers and Potential Obstacles to Low-Lying Peoples' Ex Situ Self-Determination}

\section{Introduction}

Low-lying States have relatively clear duties to ensure their peoples' enjoyment of the right to self-determination. Other States' duties are described only broadly, relating to refraining from actions that adversely affect enjoyment of the right, and generally promoting the right, which can involve cooperating with the UN on relevant matters. Additional guidance about duties can be garnered from the Paris Agreement, and the UN has its own powers and functions. Fundamentally, however, a low-lying State has no right to claim another State to forsake any jurisdiction, which may be necessary for any reasonable attempt to enjoy in relocation the substantive and procedural entitlements that comprise self-determination. The combined force of the erga omnes right per se, the general duties on all States, and the relevant functions and powers of the UN may build awareness and support for ex situ self-determination. Nevertheless, the problem persists that there is no specific third-party State with particular obligations to support low-lying peoples' relocation enterprises and ex situ self-determination.

In an attempt to confront this problem, this chapter analyses the nature of the duties on each potential duty-bearer as those duties might relate to low-lying peoples' relocation enterprise. It also considers other pathways for supporting this endeavour. Specifically, Part II looks at the duties of low-lying States, third-party States, partner States and the United Nations. It also looks in more detail at the challenge outlined above - the lack of specific third-party State duties - as well as various reasons why a third-party State might volunteer to become a partner State. Part III then looks to the Paris Agreement to provide extra clarity on the duties of third-party States with respect to ex situ self-determination, which is a means of adapting to climate change. Part IV looks at further obstacles to ex situ self-determination. Finally, part V synthesises all the self-determination analysis in chapters 2 and 3. 


\section{Duty-Bearers}

It is already established that the communities of the low-lying States are peoples with the right to self-determination. ${ }^{414}$ A more difficult question is identifying parties with correlative obligations regarding the enabling, facilitation and fulfilment of the peoples' right ex situ. ${ }^{415}$ Simma notes that multilateral treaties such as the 1966 human rights covenants "cannot simply be split up into a series of bilateral treaty relationships". 416 Consequently, it is impossible to identify specific States with specific legal duties regarding specific low-lying States and their relocation enterprises. ${ }^{417}$ Nevertheless, the OHCHR has concluded that: ${ }^{418}$

\footnotetext{
While there is no clear [precedent] to follow, it is clear that insofar as climate change poses a threat to the right of peoples to self-determination, States have a duty to take positive action, individually and jointly, to address and avert this threat.
}

In making this claim, the OHCHR failed to explain the authorities for, or scope of, this duty. Given the necessity of third-party States' involvement in low-lying peoples' cross-border relocation, this chapter tests this "duty to take positive action". This is a central element of developing a thorough understanding of the possible roles self-determination law might play in these relocation enterprises.

In looking for the existence of duties regarding low-lying peoples' self-determination, the duty-bearers considered here are: the low-lying States themselves; third-party States; partner States, that is, third-party States that welcome low-lying islanders; and the UN. Linked to the question of the existence of these actors' duties is the nature of those obligations. Thus, the general scope of their respective duties and powers

\footnotetext{
414 Chapter 2, Part IV.

415 Thürer and Burri, above n 148, at 118; and Pascoe, above n 61, at 82.

416 Bruno Simma "From Bilateralism to Community Interest in International Law" 250 Recueil des Cours de l'Académie de Droit International (1994-VI) 217 at 336.

417 Specific third-party States can be identified as having moral obligations: Willcox, above n 162, at 8184.

418 OHCHR, above n 302, at [41].
} 
is also identified. This scope varies according to the proximity of the relationship to the peoples.

\section{A. Low-lying States}

In the ICCPR, each State undertook "to respect and to ensure to all individuals within its territory and subject to its jurisdiction the rights recognized in the present Covenant". ${ }^{419}$ Self-determination is one of those rights. Therefore, the low-lying States hold the primary responsibilities with respect to the self-determination of their own peoples. ${ }^{420}$ This applies also in the climate change context. When adopting the Paris Agreement, which includes obligations towards adapting to the impacts of climate change, ${ }^{421}$ the COP stated that "Parties should, when taking action to address climate change, respect, promote and consider their respective obligations on human rights". ${ }^{422}$ The OHCHR suggests that "States must ensure that appropriate adaptation measures are taken to protect and fulfil the rights of all persons". ${ }^{423}$ Since relocation is adaptation, low-lying States' obligations include facilitating this in a way that seeks to maintain self-determination. In practice, this may be establishing goals and processes for the protection and progressive realisation of the right ex situ, during and after a relocation enterprise conducted over time.

Identifying the low-lying States as the principal duty-bearers and asserting that "it should be an act of self-determination" 424 is easy, yet the challenge is immense. The low-lying States all have limited economic capacity and political clout, and the

419

20 peoples lies with the state itself": International Commission on Intervention and State Sovereignty The Responsibility to Protect (December 2001) at XI.

421 Article 7; and see Part III of this Chapter.

422 UNFCCC Report of the Conference of the Parties on its twenty-first session, held in Paris from 30 November to 13 December 2015 FCCC/CP/2015/10/Add.1 (2015), Decision 1/CP.21, Adoption of the Paris Agreement, at preamble, seventh recital.

423 OHCHR, above $\mathrm{n} 273$, at 2 .

424 Thürer and Burri, above n 148, at 118-119. See also Principles which should guide Members in deciding whether or not an obligation exists to transmit the information called for in Article 73e of the Charter GA Res 1541, XV (1960) [Resolution 1541], Principle VII(a) and IX; and Western Sahara, above n 255, at 32-33. 
practical challenges for relocating entire populations are vast. Moreover, they need to be sensitive to, and manage the competing demands of, any partner States. Regardless, low-lying States are responsible for taking appropriate steps to secure the self-determination of their peoples. ${ }^{425}$

\section{B. Third-party States}

The ILA Committee on International Law and Sea Level Rise has concluded that "[a]ny migration or relocation strategies must be developed and executed in a manner fully consistent with the minimum standards of protection articulated under human rights law". ${ }^{426}$ The ILA recognises that those standards include self-determination. ${ }^{427}$ Since these strategies are bilateral or multi-country, there are international expectations that third-party States assist with the self-determination of relevant peoples outside those States' jurisdictions. This section identifies the authorities for third-party States' duties and the nature of those duties.

States have a duty to cooperate "in the promotion of universal respect for, and observance of, human rights and fundamental freedoms for all". ${ }^{428}$ This is, McAdam explains, "a fundamental principle of international law." ${ }^{429}$ Consistent with this duty, the ICJ stated in the Namibia advisory opinion that: ${ }^{430}$

... all States should bear in mind that the injured entity is a people which must look to the international community for assistance in its progress towards the goals for which the sacred trust was instituted.

425 See McAdam and others, above n 138, at [112]-[115]; and Margaux J Hall and David C Weiss "Avoiding Adaptation Apartheid: Climate Change Adaptation and Human Rights Law" (2012) 37 YJIL 309 at 351.

426 ILA Committee on International Law and Sea Level Rise, above n 54, at 24.

427 ILA Committee on International Law and Sea Level Rise Resolution 6/2018 (August 2018) annex ('Sydney Declaration of Principles on the Protection of Persons Displaced in the Context of Sea Level Rise') [Sydney Declaration] at 6(4).

428 Friendly Relations Declaration, above n 226, at 123; and see Charter of the United Nations, art 1(3).

429 McAdam and others, above n 138, at [119].

$430 \quad$ Namibia advisory opinion, above n 255, at 56. 
The Court here is linking the right to self-determination to non-self-governing territories (NSGTs) and the trusteeship system, ${ }^{431}$ and adds that "all States" should anticipate calls for assistance.

More generally, the Committee on the Elimination of Racial Discrimination has explained: 432

$\ldots$ it is the duty of States to promote the right of self-determination of peoples [and] the implementation of the principle of self-determination requires every State to promote, through joint and separate action, universal respect for and observance of human rights and fundamental freedoms in accordance with the Charter.

The central authorities for these duties are the Universal Declaration of Human Rights and the 1966 Covenants. The Universal Declaration commits "every individual and every organ of society" to "progressive measures, national and international". 433 In article 22, Member States confirmed that:

Everyone $\ldots$ is entitled to realization, through national effort and international co-operation $\ldots$ of the economic, social and cultural rights indispensable for his dignity and the free development of his personality.

While the Universal Declaration does not refer to self-determination, these commitments for international cooperation regarding human rights generally are bolstered by common art 1(3) of the 1966 Covenants, which provide that:

The States parties to the present Covenant ... shall promote the realization of the right of self-determination, and shall respect that right, in conformity with the provisions of the Charter of the United Nations.

431 At 31 .

432 Report of the Committee on the Elimination of Racial Discrimination A/51/18 (1996) annex III ('General Recommendation XXI (48), adopted at the 1147th meeting, on 8 March 1996') [General Comment 21] at 125; Human Rights Committee, above n 288, at 209, [3].

433 Universal Declaration of Human Rights GA Res 217 A(II) (1948) at preamble, eighth recital. 
These are general obligations of both a positive ("promote") and negative ("respect") nature, applicable to all States. The OHCHR clarifies that art 1(3): ${ }^{434}$

... imposes specific obligations on States parties, not only in relation to their own peoples but vis-à-vis all peoples which have not been able to exercise or have been deprived of the possibility of exercising their right to self-determination. ... [A]ll States parties to the Covenant should take positive action to facilitate realization of and respect for the right of peoples to self-determination. Such positive action must be consistent with the States' obligations under the Charter of the United Nations and under international law: in particular, States must refrain from interfering in the internal affairs of other States and thereby adversely affecting the exercise of the right of self-determination.

The following discussion identifies these negative and positive duties on third-party States as they would apply to the low-lying States' relocation enterprises.

\section{Negative duties}

The Friendly Relations Declaration develops the negative duties associated with self-determination in art 1(3) by stating that "any attempt aimed at the partial or total disruption of ... a State['s] ... political independence is incompatible with the purposes and principles of the Charter". ${ }^{435}$ Accordingly, "[e]very State has the duty to refrain from any forcible action which deprives people ... of their right to self-determination and freedom and independence". ${ }^{436}$ The ICJ has elaborated on these principles in its Israeli Wall advisory opinion. A central pillar of reasoning in that opinion is the importance of the right of Palestinians to self-determination as encapsulated in the Friendly Relations Declaration. ${ }^{437}$ The ICJ explained: ${ }^{438}$

Given the character and the importance of the rights and obligations involved, the Court is of the view that all States are under an obligation not to recognize the illegal situation resulting

\footnotetext{
434 General Comment 12, above n 288, at [6].

435 Friendly Relations Declaration, above n 226, at preamble, fourteenth recital.

436 At 124.

437 Israeli Wall advisory opinion, above n 168, at 200 [159].

438 At 200 [159].
} 
from the construction of the wall in the Occupied Palestinian Territory, including in and around East Jerusalem. They are also under an obligation not to render aid or assistance in maintaining the situation created by such construction.

Such negative duties on third-party States are relevant to the low-lying States' scenarios. The effect of these duties may be that third-party States must refrain from taking political or practical measures that adversely affect the enjoyment of self-determination and political independence by the peoples of other States. This would be consistent with the principles of non-interference in States' domestic affairs and respect for political integrity. ${ }^{439}$ In light of all these principles, it is arguable that third-party States have a duty to refrain from removing recognition of low-lying States' statehood. If this is correct, as will be argued later, ${ }^{440}$ then this duty on third-party States regarding the lowlying States' external self-determination will persist when the latter is forced to undertake measures to secure that right ex situ.

There is neither authority nor principled reason that suggests the erga omnes obligation to respect others' self-determination is qualified according to the nature or perceived gravity of the exogenous forces that threaten its enjoyment. For example, whilst the breach by Israel of the Palestinians' right may be more severe and immediate, and although the nature of the breach involves a peremptory norm (the prohibition of the use of force), Palestinians' right to self-determination is not greater in extent or value than that of Tuvaluans, I-Kiribati and other low-lying peoples. It is important to distinguish between the right itself, and the nature of the forces affecting it. Without that distinction, one might err in thinking the right itself is less worthy for one people than another. It is correct to say that international responses to self-determination concerns have so far related to direct threats from human actors and actions. International responses have not yet needed to be concerned with the environmental threats to self-determination caused indirectly by human actors. This lack of precedent is perhaps reflected in the Friendly Relations Declaration, which interprets the rule of self-determination as meaning

439 VCLT, at preamble, sixth recital; and Military and Paramilitary Activities in and against Nicaragua (Nicaragua v United States) (Merits) [1986] ICJ Rep 14 [Nicaragua] at 106.

440 Chapter 4, Part VII. 
"[e]very State has the duty to refrain from any forcible action that deprives people ... of their right". ${ }^{441}$ Referring to General Assembly resolutions and practice regarding colonisation situations, Cassese's interpretation of this rule and the reference to "forcible" is that it applies to all repressive and coercive measures, not just military. ${ }^{442}$ Regardless, the right to self-determination does not exist only in situations of violence and oppression. It belongs to, and is equal for, all peoples, irrespective of the nature of exogenous forces that might challenge its enjoyment. Thus, the right to self-determination is as equal for low-lying islanders in their factual situations as it is for other peoples. Hence, the negative duties in the ICJ described in the Israeli Wall advisory opinion apply equally to the low-lying peoples.

\section{Positive duties}

The Friendly Relations Declaration imposes on third-party States more burdensome, positive obligations: ${ }^{443}$

Every State has the duty to promote, through joint and separate action, realization of the principle of equal rights and self-determination of peoples, in accordance with the provisions of the Charter, and to render assistance to the United Nations in carrying out the responsibilities entrusted to it by the Charter regarding the implementation of the principle.

These duties of States to work with peoples trying to realise self-determination, and to work with the UN, are reflected in Security Council Resolution 389 (1976) regarding East Timor. The UNSC called upon all States to "co-operate fully with the United Nations to achieve a peaceful solution to the existing situation and to facilitate the decolonization

441 Friendly Relations Declaration, above n 226, at 124.

442 Cassese, above n 146, at 197.

443 Friendly Relations Declaration, above n 226. Contrast Raič, who concludes "there is no, or at least insufficient, state practice to support the position that States are under an obligation to actively promote the realization of the right of self-determination of peoples living outside their borders": Raič, above n 148, at 428 . 
of the Territory."444 Those ideas were also expressed in the Israeli Wall advisory opinion: 445

It is also for all States, while respecting the United Nations Charter and international law, to see to it that any impediment, resulting from the construction of the wall, to the exercise by the Palestinian people of its right to self-determination is brought to an end.

Similarly, in the decolonisation situation of the Chagos Archipelago, the ICJ stated that "all Member States must co-operate with the United Nations to complete the decolonization of Mauritius." 446

It follows that third-party States must "promote ... realization" of self-determination of low-lying peoples, and render assistance to the UN with the exercise of its functions and powers (which are examined later) ${ }^{447}$ in respect of low-lying States. This assistance may take the form of direct assistance, such as finance or participation in the work of UN organs. Fulfilling positive obligations may involve supporting low-lying States' ongoing membership of international organisations, which implies ongoing recognition of statehood. ${ }^{448}$

\section{The potential for passive undermining of self-determination}

This part began by finding that it is impossible to identify particular third-party States that have clear legal duties towards specific low-lying peoples' relocation enterprises. As a result of this current law, it is open to other States to ignore or give minimum effect to their general duties regarding self-determination. If a number of

444 Security Council resolution 389, S/RES/389 (1976) [the question of East Timor] at [5].

445 Israeli Wall advisory opinion, above n 168, at 200 [159].

446 Chagos Archipelago, above n 228, at [182]. The UK has responded to the Advisory Opinion, saying "we do not share the Court's approach", but this relates to conclusions on British sovereignty over the Chagos Archipelago rather than the law of self-determination: Alan Duncan "British Indian Ocean Territory" (Foreign and Commonwealth Office, Written statement - HCWS1528, 30 April 2019) available at <www.parliament.uk>.

447 This Chapter, Part II(D).

448 Raič, above n 148, at 428-429. 
third-party States each take some migrants under ordinary immigration schemes, rather than as a people, then none of those States are responsible, and the project of ex situ self-determination would be undermined. As part of fulfilling their own duties to their peoples, low-lying States will need to be very assertive in highlighting at regional and multilateral fora their peoples' right and third-party States' duties, as outlined in this section. This diplomacy will be critical to building momentum towards ensuring their peoples' rights are acknowledged by the international community and potential partner States, and then reflected in relevant binding agreements, voluntary cooperation initiatives, and the development of guidance materials and soft law.

\section{Partner States ${ }^{449}$}

For low-lying States obliged to ensure their peoples' self-determination in the relocation enterprise, a key question is, which third-party States will they partner with to attempt this, and what are the duties of these partner States? This section looks at potential non-binding pathways for identifying partner States, some functional reasons for volunteering to be a partner State, and the duties involved in doing so.

\section{Identifying partner States}

As discussed, international law does not create any obligations on third-party States to partner with low-lying States in the relocation enterprise. While all States are responsible for the general negative and positive duties, it is impossible to identify specific States with specific positive legal duties with respect to the relocation and self-determination of specific low-lying peoples. Nevertheless, there are reasons why a third-Party State might engage in this relocation enterprise beyond simple migration schemes. Voluntary, political impetus for support may come from important current and historical relationships. ${ }^{450}$ In the Pacific, for example, Kiribati, the Marshall Islands and

449 "Partner State" is defined in Chapter 1, Part IV(A).

450 Compare to Willcox who identifies the "reasons for acting" as obligations of international cooperation, contribution to climate change, and capacity to act. Based on those reasons, Willcox concludes that "Australia and New Zealand can and should bear primary responsibility for assisting atoll islanders in the Pacific region, at least": Willcox, above n 162, at 82-83. 
Tuvalu are three of 16 members of the Pacific Islands Forum (PIF). The Agreement establishing the PIF $^{451}$ and the PIF's Framework for Pacific Regionalism ${ }^{452}$ are non-binding but contain principles reflecting the region's history of collaboration. For example, Member States affirmed "the principle of the equality of all its members", 453 and that they are "determined to work in partnership with each other" 454 for "a region ... whose people can all lead free and worthwhile lives". ${ }^{455}$ The Members are "seeking a future in which [the region's] cultures, traditions and religious beliefs are valued, honoured and developed". ${ }^{456}$ This is echoed in the Framework for Pacific Regionalism, which adds: ${ }^{457}$

We support full inclusivity, equity and equality for all people of the Pacific.

We strive for effective, open and honest relationships and inclusive and enduring partnerships — based on mutual accountability and respect—with each other, within our subregions, within our region, and beyond.

In addition to these principles, PIF members agree that a key regional issue is "responding to climate change, and improving livelihoods and wellbeing". ${ }^{458}$ One of the actions agreed is "[a]dministrative / legal / institutional integration [to achieve] a secure and well governed Pacific region pledged to upholding regional values." ${ }^{459}$ PIF Leaders also agreed to a strategy for managing climate change issues regionally, which includes references to "human mobility aspects ... displacement and migration ... [and] relocation and labour migration policies". ${ }^{460}$ The strategy also directs regional organisations to

451 Agreement establishing the Pacific Islands Forum [2005] ATNIF 28 (signed 27 October 2005, not yet in force).

452 The Framework for Pacific Regionalism (Pacific Islands Forum Secretariat, Suva, July 2014).

453 Agreement establishing the Pacific Islands Forum, above n 451, at preamble, seventh recital.

454 At preamble, fourth recital.

455 At preamble, first recital.

456 At preamble, second recital.

457 The Framework for Pacific Regionalism, above n 452, at 3.

458 At 11.

459 At 4.

460 Framework for Resilient Development in the Pacific: An Integrated Approach to Address Climate Change and Disaster Risk Management (FRDP) 2017-2030 (Pacific Islands Forum, 11 September 2016) [FRDP] at 22. 
"[c]onduct studies and support the development of appropriate national strategies on relocation due to climate change and disaster impacts". ${ }^{461}$ These regional statements are non-binding and do not directly address the right to self-determination of Pacific peoples, nor identify specific bilateral relationships in climate-related relocation enterprises. This reemphasises the challenge of there being no clear bilateral partners for low-lying States. However, in these developments, Pacific States are beginning to elaborate the problem definition and build momentum for addressing climate-related relocation and the issues it raises.

The aforementioned statements also set the tone of the bilateral and regional relationships regarding action to address the challenges. That tone is starting to be reflected in practice, with cooperation on climate migration increasing gradually in the region. Notably, Fiji has voluntarily offered to "give permanent refuge to the people of Kiribati and Tuvalu", ${ }^{462}$ has sold land to the Kiribati Government, ${ }^{463}$ and has announced it will create a legal framework for climate migration. These developments have occurred while Fiji is facing its own internal climate migration. ${ }^{464}$

Similar policy steps are emerging in New Zealand. In the lead-up to the 2017 general election, the New Zealand Labour Party committed to "stand by [Pacific communities] and support their right to migrate and settle with dignity", ${ }^{465}$ echoing the oft-repeated words of former I-Kiribati Present Tong. After that election, the new Minister for Climate Change, James Shaw (Green Party of Aotearoa New Zealand),

461 At 24.

462 Frank Bainimarama, Prime Minister of Fiji and incoming President of the UN Climate Change Conference in Bonn in November (COP23) "Pacific Islands Need to Lead Global Climate Action Agenda" (Pacific Climate Partnership Event, Grand Pacific Hotel in Suva, Fiji, 3 July 2017); and see Radio New Zealand "Fiji reiterates climate migration help to Kiribati" (14 July 2015) <www.radionz.co.nz>.; and see Office of the President of Kiribati, above n 89.

463 James Ellsmoor and Zachary Rosen "Kiribati's land purchase in Fiji: does it make sense?" (11 January 2016) DevPolicy <www.devpolicy.org>.

464 Jess Shankleman "A Tiny Island Prepares the World for a Climate Refugee Crisis" (15 November 2017) Bloomberg <www.bloomberg.com>; and Aqela Susu " $\$ 1.6 \mathrm{~m}$ relocation plan for seven households" Fiji Times (Suva, online ed, 5 October 2016).

465 Leah Te Whata "Labour Party promises to support Pacific climate change refugees" Māori Television (online ed, Auckland, 16 July 2017). 
announced a possible experimental humanitarian visa. ${ }^{466}$ This policy was deferred but the coalition Government has adopted an action plan on "Pacific climate change-related displacement and migration". This involves directing official development assistance and other work towards "a multi-sectoral response to prepare for climate migration through migration-readiness ... to promote better settlement outcomes in case of future crossborder climate migration." ${ }^{467}$ Importantly, this action plan is underpinned by three highlyaspirational "core values", including self-determination. These are: ${ }^{468}$

- Honour Pacific Leaders' recognition of 'the importance of retaining the Pacific's social and cultural identity, and the desire of Pacific peoples to continue to live in their own countries, where possible'.

- Respect and uphold Pacific Island countries' sovereignty and the right to self-determination.

- Encourage transparent, inclusive dialogue on Pacific climate migration domestically, regionally and internationally, advocating for Pacific priorities:

i. Internationally, recommend that any solution be led and owned by those countries most significantly impacted, with support from partners; and

ii. In the regional context, advocate for a Pacific-led response through the Pacific Islands Forum as the preeminent regional body.

This appears to be the first recognition by a State that climate relocation policy should respect and uphold self-determination. We may not know for some time how the New Zealand government will translate this "core value" into policy, as the "early actions" are intended to inform its longer-term approach to the issue, which will be decided in 2024. ${ }^{469}$ Nevertheless, this is a significant development in that it recognises for the first time that climate relocation relates to peoples with rights to self-determination, not just to individuals and families. It has the potential to set a tone for other developments in the region and elsewhere.

Stuff "Government considering experimental climate change visa" (1 November 2017) <www.stuff.co.nz>.

467 CAB-18-MIN-0218, above $\mathrm{n}$ 90, at [24(I)].

468 At [23], citing the Niue Declaration, above n 7, at preamble, fifth recital.

469 CAB-18-MIN-0218, above n 90, at [37(6)]. 
Particular historical ties underpin other relationships that may be helpful in identifying a potential partner State. The Maldives has been independent since at least 500 BCE. $^{470}$ Voluntarily, however, it sought the status of, and became a British Protectorate from 1887 until 1965 to avoid political interference from other European colonial powers. ${ }^{471}$ Based on that relationship, the Maldives might call on the United Kingdom for support with climate-related relocation. However, basing climate migration on this type of historical relationship is problematic. The United Kingdom has colonial historical links with Kiribati and Tuvalu, and other historical links with the Marshall Islands. It is unrealistic to expect Britain to assist all low-lying peoples with ex situ self-determination. It is also very likely to be undesirable for the low-lying peoples, who have few cultural or other ties with the British people. Moreover, this option may be considered as something akin to re-colonisation. Overall, this type of historical tie is unhelpful for identifying potential partner States.

Differently, the Marshall Islands currently enjoys special ties with the United States as a constitutional government in free association under the Compact of Free Association. ${ }^{472}$ The two States have agreed that Marshallese citizens may "establish residence as ... non-immigrant[s] in the United States". ${ }^{473}$ The Compact recognises that the Marshall Islands' constitutional arrangements (including the Compact) are giving effect to the Marshallese's "sovereign right to self-determination". ${ }^{474}$ Any US duty with respect to Marshallese self-determination may, therefore, be affected by this residency option. This is especially so since nearly 15 per cent of all Marshallese already live in

470 John Stewart Bowmen Colombia Chronologies of Asian History and Culture (Columbia University Press, New York City, 2000) at 389-390.

471 The Commonwealth "Maldives: History" <thecommonwealth.org>; BBC "Maldives Profile: Timeline" <www.bbc.com>; Central Intelligence Agency "South Asia: Maldives" The World Factbook <www.cia.gov>; and Encyclopædia Britannica "Maldives" <www.britannica.com>.

472 Central Intelligence Agency "Australia-Oceania: Marshall Islands" The World Factbook <www.cia.gov>; Compact of Free Association, as amended, Between the Government of the United States of America and the Government of the Republic of the Marshall Islands [2004] (signed 30 April 2003, entered into force 1 May 2004) [RMI-US Compact of Free Association].

473 Above $\mathrm{n}$ 472, at art IV(a).

474 At preamble, fourth and sixth recitals. 
Arkansas, where there is an official consular office, and where electioneering and voting for the Marshallese government take place. ${ }^{475}$

These pathways for identifying specific partner States do not give a binding result. ${ }^{476}$ Any third-party State involvement in a low-lying people's relocation is currently voluntary. Therefore, the second duty-bearer, after low-lying States themselves, are the third-party States that voluntarily welcome large numbers of people from low-lying States. That said, these partner States will probably be those with existing ties. Already, and without any legal basis for these choices, Kiribati's indicated preference is to purchase land in Fiji, New Zealand or Australia, ${ }^{477}$ and Tuvalu's expressed preference is land in New Zealand or Australia. ${ }^{478}$

\section{Functional Reasons for Why a State Might Volunteer to Become a Partner State}

Since there are no binding bilateral obligations, and 'crisis' narratives in mainstream media suggest that climate migration only involves costs for destination States, ${ }^{479}$ what incentives are there for third-party States to partner in low-lying peoples' ex situ self-determination? Certain historical or existing relationships suggest logical partners for the enterprise, as discussed previously. But there are two possible functional reasons regarding economics and international stability. These concepts require deeper analysis but are introduced here to highlight the potential for overcoming crisis narratives.

First, supporting low-lying peoples' ex situ self-determination may have economic benefits that compensate to some degree for any costs. In particular, the relocation

475 John D Sutter "You're Making This Island Disappear" (June 2015) CNN <www.cnn.com>.

476 An alternative proposal for identifying duty-bearers involves examining States' contributions to of overall greenhouse gas emissions, along with States' availability of resources to assist: Willcox, above n 162, at 57-60. Whilst these bases for identifying particular duty-bearers may be attractive from a moral standpoint, their legal foundations are unsatisfactory.

477 Alistair Doyle "Kiribati President Favors Buying Land Elsewhere As Islands Are Threatened By Rising Sea Levels" (22 September 2014) Huffington Post <www.huffingtonpost.com>.

478 Radio New Zealand "Tuvalu looking at buying NZ and Aust land for displaced" (24 August 2015) <www.radionz.co.nz>.

479 For example, see Shankleman, above n 464. 
enterprise may act as a large-scale overseas investment in the partner State. The development of housing and relevant infrastructure may be financed through international mechanisms, such as the Green Climate Fund, ${ }^{480}$ or bilateral funding from low-lying States' development partners, the low-lying State's economic assets, private investments, or some combination of finance from sources outside the destination State's economy.

Additionally, supporting self-determination may mitigate the cost of supporting less aspirational, migration-only policies, which will likely result in the long-term costs of individual, social and economic impoverishments. ${ }^{481}$ Such potential benefits need to be accounted for in economic analyses. ${ }^{482}$

Secondly, supporting ex situ self-determination supports the international rules-based system, which is currently under "significant pressure" with changing global power balances and rising nationalism. ${ }^{483}$ If States wish to be beneficiaries of globalism, their support for that project is evidenced by their acting consistently with international law and norms. ${ }^{484}$ Hathaway argues that "compliance [with international treaty law] not only depends on the decision to commit, but commitment also depends upon the decision to comply." ${ }^{485}$ Decisions on whether to support low-lying peoples' relocations and ex situ self-determination need to consider the progressive development of international law consistent with fundamental elements, such as the right to self-determination. ${ }^{486}$

$$
\begin{aligned}
& \text { FCCC/TP/2013/2 (2013). } \\
& \text { Ben King, Deputy-Secretary of } \\
& \text { changing world" (University } \\
& \text { <www.mfat.govt.nz>. } \\
& \text { Koh, above n 128, at xiii-x. } \\
& \text { Hathaway, above n 129, at } 473 \text {. } \\
& \text { Chapter 1, Part V(B). }
\end{aligned}
$$
Adaptation and Theories of Justice" (University of San Francisco Law Research Paper 2016-01); Maguire and McGee, above n 75; Ödalen, above n 139; Mathias Risse "The Right to Relocation: Disappearing Island Nations and Common Ownership of the Earth" (2009) 23(3) Ethics and International Affairs 281. They also need to account for non-economic losses. See UNFCCC Non-economic losses in the context of the work programme on loss and damage: Technical paper changing world" (University of Canterbury, New Zealand, 20 September 2018) available at 
Scelle's dédoublement fonctionnel theory also highlights that partner States' actions will act as exemplars in international norm-setting. ${ }^{487}$ This theory posits that States' functions on the international plane are two-fold: law-making; and adjudication and enforcement. ${ }^{488}$ One consequence of these roles is that: ${ }^{489}$

\footnotetext{
... any time [a national agent performs a legal act that] deals with an international situation or an international relation, it falls within the purview of the international legal order, and must be regarded as an international act.
}

Volunteering to be a partner State will be such an international act. Thus, in view of the dédoublement fonctionnel theory, partner States should consider how their interpretation of international law and relevant actions might set a precedent for analogous circumstances. For instance, Fiji's treatment of I-Kiribati people in its emerging relocation partnership, ${ }^{490}$ or how New Zealand gives effect to its "core value" of upholding self-determination, ${ }^{491}$ may influence how other States deal with other low-lying States and their peoples. Similarly, and again reflecting Scelle's theory, partner States' actions may relate to quasi-enforcement of international law. ${ }^{492}$ To illustrate with a hypothetical: if a partner State agrees that the low-lying State can maintain its international legal personality within the partner State's territory, then the partner State is simultaneously signalling to other States that they must not withdraw recognition of the low-lying State's statehood, as this would be inconsistent with the principle that States must not "intervene, directly or indirectly, for any reason whatever, in the internal or external affairs of any other State." 493

Again, each of these concepts will require deeper investigation by low-lying States, partner States and other key stakeholders. However, it is important to lay out potential

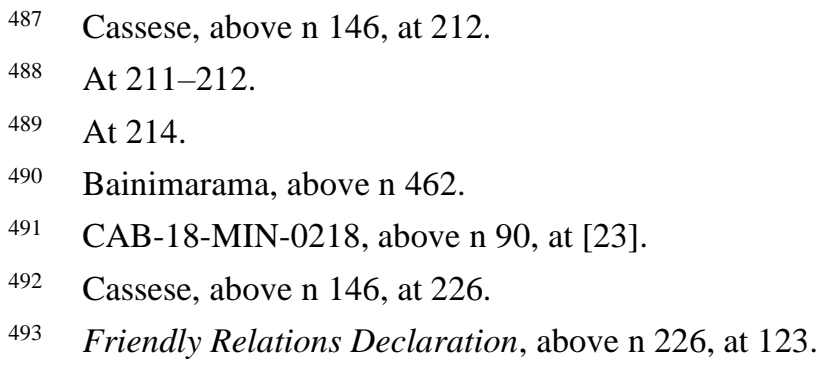


benefits of these partnerships, since current narratives are almost exclusively negative, which exacerbates the risks for low-lying peoples.

\section{Duties of partner States}

As already noted, no third-party State is obliged to become a partner State in a low-lying people's relocation enterprise and their ex situ self-determination. However, if one does volunteer for this role, this will import duties in international law. These duties may be seen as further disincentives by third-party States, but there are numerous ways that relocation and ex situ self-determination can be positively facilitated, as will be discussed later, and the previous section introduced other potential benefits that may counterbalance the costs. But partner States will have general duties with respect to low-lying peoples' self-determination, however the relocation enterprise is framed.

The general duties applicable to all third-party States, as discussed above, ${ }^{494}$ are also relevant to partner States. For instance, they must refrain from measures that adversely affect the right to self-determination. A specific example of this is the duty to refrain from removing recognition of statehood, which is examined in chapter $4 .{ }^{495}$ Another general duty applicable to partner States is cooperating with the UN where it supports the low-lying peoples' self-determination. ${ }^{496}$ There are no precise guidelines on what partner States' expectations might be in this regard, but an example may be that where the UN supports processes and plans for enabling ex situ self-determination, partner States, as key stakeholders, could engage constructively.

The factual circumstances point to further, high-level policy considerations from partner States. Robust policy must acknowledge that climate adaptation measures carry risks of loss and damage, ${ }^{497}$ including those particular to cross-border relocation. ${ }^{498}$

\footnotetext{
494 This Chapter, Part II.

495 See Chapter 4, Part VII.

496 Chapter 5, Part II(B)(2).

497 Preamble, seventh recital.

498 Chapter 1, Part III.
} 
Addressing those risks will involve a "country-driven, gender-responsive, participatory and fully transparent approach"499 to relocation, which will be one element of "promot[ing], through joint and separate action, realization of the principle of equal rights and self-determination of peoples". ${ }^{500}$ If the low-lying State's statehood continues as an element of self-determination, then any agreement regarding the relocation will need, functionally, to define the division of responsibilities for those human rights protections between the two States. Also, the partner State, the low-lying State and other key stakeholders will need to determine how to translate the general duties applicable to all third-party States to the specific requirements of the relocation enterprise.

\section{The United Nations}

Other than States, no international actors have binding duties in international law. However, some have legal powers and roles that are relevant to assisting low-lying peoples in their relocation enterprise, including the UN, and its organs and agencies. For instance, Nauru has proposed a UNSC Special Representative on Climate Change and Security, ${ }^{501}$ and Tuvalu has proposed a Special Representative of the Secretary-General on the issue. ${ }^{502}$ There are debates about whether addressing climate change is a role for the Economic and Social Council, ${ }^{503}$ and Vanuatu is considering legal action at the ICJ or other international courts. ${ }^{504}$ The Human Rights Council is also taking a role, such as its decision to undertake a research programme on climate change,

$499 \quad \operatorname{Art} 7(5)$.

500 Friendly Relations Declaration, above n 226 (emphasis added).

501 UNSC "Security Council: 8541st Meeting (AM) SC/13677: Massive Displacement, Greater Competition for Scarce Resources Cited as Major Risks to Security Council Debate on ClimateRelated Threats" (25 January 2019) <www.un.org>.

502 UNSC "Security Council Meeting 8307th Meeting (AM) SC/13417: Addressing Security Council, Pacific Island President Calls Climate Change Defining Issue of Next Century, Calls for Special Representative on Issue" (11 July 2018) United Nations <www.un.org>; and UNGA "Tuvalu: H. E. Mr Enele Sosene Sopoaga, Prime Minister: Statement Summary" (27 September 2018) <gadebate.un.org>.

503 The General Assembly recognises that "the responsibility for sustainable development issues, including climate change, [is] conferred upon the General Assembly and the Economic and Social Council": Resolution 63/281, above n 20, at preamble, third recital.

504 Nannetew "Three-Point Q and A with Hon Ralph Regenvanu, Minister of Foreign Affairs, International Cooperation and External Trade, Vanuatu at the UN Climate Conference" (11 December 2018) SPREP <www.sprep.org>. See also Chapter 1, Part V(B). 
migration and human rights. ${ }^{505}$ While all of these international organisations may have future roles, this section introduces only the roles of the UN and the General Assembly, since a specified purpose of the UN is to promote self-determination.

The UN is authorised to act in accordance with its purposes, set out in art 1 of the Charter: $:^{506}$

2. To develop friendly relations among nations based on respect for the principle of ... self-determination of peoples ...;

3. To achieve international cooperation in solving international problems of an economic, social, cultural, or humanitarian character, and in promoting and encouraging respect for human rights and fundamental freedoms for all ...; and

4. To be a center for harmonizing the actions of nations in the attainment of these common ends.

Relative to these purposes, the General Assembly has wide-ranging, discretionary powers, which are relevant to the low-lying States' situations. For example, under art 13(1)(a), it has the power to initiate studies and make recommendations on international cooperation regarding: economic, social, cultural, educational and health fields; human rights; and the progressive development of international law. (The Economic and Social Council enjoys almost identical powers. $)^{507}$ Similarly, under art 11, the General Assembly may discuss "any questions relating to the maintenance of international peace and security", which could include the threats to security posed by the environmental changes affecting low-lying States. ${ }^{508}$ Furthermore, under art 14 , the

Human Rights Council Human rights and climate change A/HRC/35/L.32 (2017) at [10]-[12].

Charter of the United Nations, arts 1(2)-1(4).

Article 62(1)-62(2).

Makurita Baaro, Permanent Representative of Kiribati to the United Nations, explained that climate change is "the greatest threat to the livelihoods, security and well-being" of the Pacific Region: United Nations Climate Change Greatest Threat to Small Island States, Delegate Tells Second Committee, Urging Critical International Support for Survival: Sixty-Eighth General Assembly: Second Committee: Panel Discussion (AM) (meeting report, GA/EF/3381, 1 November 2013). This reflects the Boe Declaration adopted by Pacific Islands Forum Leaders in 2018: "We reaffirm that climate change remains the single greatest threat to the livelihoods, security and wellbeing of the peoples of the Pacific": above n 20, at [1]. See also Resolution 63/281, above n 20; UNSC, above n 501; UNSG 
General Assembly has a broad power to "recommend measures for the peaceful adjustment of any situation, regardless of origin, which it deems likely to impair the general welfare or friendly relations among nations".

These powers could be used to examine the unprecedented situations emerging for its low-lying Member States. In Western Sahara, the ICJ deferred to the General Assembly's discretion with these powers, but with respect to self-determination, suggested that the UN assist with consultations between interested States, and with devising "the procedures and guarantees required for ensuring a free and genuine expression of the will of the people". 509

Regarding climate migration, the UNFCCC's Task Force on Displacement has recommended more specifically that the UN and its agencies: ${ }^{510}$

(a) Continue to support efforts, including finance, technology and capacity building ... to avert, minimize and address displacement ...;

(b) Support and enhance regional, subregional and transboundary cooperation ...;

(c) Continue to develop and share good practices, tools and guidelines ... for:

(i) Understanding risk;

(ii) the procedures and guarantees required for ensuring a free and genuine expression of the will of the people.

Climate change and its possible security implications: Report of the Secretary-General A/64/350 (2009); and Michael B Gerrard "The Role of Climate Change as a Threat Multiplier for Global Security" (Statement to the Security Council Open Arria Formula Meeting, 30 June 2015).

Western Sahara, above n 255, at 36-37. Regarding this, Cassese has said that "[t]he Court clearly implied that, whenever self-determination is at issue, the states concerned should be consulted, at least to the extent that such consultation may facilitate the implementation of self-determination and do not tend to negate or pre-empt the expression of popular will": Antonio Cassese "The International Court of Justice and the right of peoples to Self-Determination" in Vaughan Lowe and Malgosia Fitzgerald Fifty Years of the International Court of Justice: Essays in Honour of Sir Robert Jennings (Cambridge University Press, Cambridge, 1996) 351 at 360.

510 Task Force on Displacement, above n 82, at [34]. 
It is submitted that, in carrying out any of these functions with respect to low-lying peoples' ex situ self-determination, and in order to be consistent with its purposes, the UN could:

1) Recognise the importance of protecting the continuity of statehood for low-lying States, given the paramount importance of the State in the international legal order, and the fact that the State being the principal protector of its peoples' human rights $^{511}$ and the supreme means by which self-determination is effectuated;

2) Initiate studies examining the risks and structural barriers to preserving ex situ the low-lying peoples' inalienable right to self-determination;

3) Initiate studies into the role of international cooperation and the progressive development of international law in supporting low-lying States' relocation enterprises and their peoples' ex situ self-determination; and

4) Make recommendations that seek to secure the procedural and substantive aspects of self-determination, as set out in the previous chapter. ${ }^{512}$

\section{E. Summarising Rights-Holders and Duty-Bearers}

It is clear that the low-lying States are the primary duty-bearers with respect to their respective peoples' enjoyment of the right to self-determination. The international community has also legally committed third-party States to assisting with that objective, through general public international law and through climate law, but it is not possible to pin precise obligations on specific third-party States; only the generic duties owed by all States. The UN and its organs and agencies have relevant roles and functions, and could play an influencing role in the formation of any relocation partnership, specifically providing guidance and monitoring on the design and implementation of that enterprise.

511 James Crawford "State" in Wolfrum, above n 148, 475 at 476.

512 Chapter 2, Part VII. 


\section{Additional Guidance on Duties from Climate Change Law}

Analysis in this thesis has so far focused primarily on self-determination law. This part demonstrates how climate law and self-determination law can each be interpreted in light of the other to assist in understanding rights and duties in relation to low-lying peoples' relocation and ex situ self-determination. There is no explicit link between the two areas of law, but others have already argued that climate law is susceptible to a human rights interpretation. ${ }^{513}$ It is argued further here that climate law's particulars can help policy-makers resolve the generalities and ambiguities in self-determination law discussed earlier, and, equally, climate law obligations should be read in light of self-determination.

Climate law is encapsulated in the 1992 UNFCCC, the 1998 Kyoto Protocol to the UNFCCC $^{514}$ and, most importantly, the 2015 Paris Agreement. None of these treaties refer directly to self-determination. The term 'self-determination' is also absent in the COP's non-binding decisions that focus on adaptation and loss and damage: the 2010 Cancun Adaptation Framework; ${ }^{515}$ the 2012 Doha Approaches to Loss and Damage; ${ }^{516}$ and the 2013 Warsaw International Mechanism for Loss and Damage. ${ }^{517}$

Regardless of these omissions, it is legitimate to bring climate law into the interpretation of common arts 1(1) of the 1966 conventions to help develop an

513 Spyridon Aktypis, Emannuel Decaux and Bronwen Leroy "Systemic integration between climate change and human rights at the United Nations?" in Ottavio Quirico and Mouloud Boumghar (eds) Climate Change and Human Rights: An international and comparative law perspective (Routledge, Abingdon, 2016) 221 at 231.

514 Kyoto Protocol to the United Nations Framework Convention on Climate Change 2303 UNTS 162 (opened for signature 11 December 1997, entered into force 16 February 2005).

515 Cancun Adaptation Framework, above n 10, in particular at [14](f).

516 UNFCCC Report of the Conference of the Parties on its eighteenth session, held in Doha from 26 November to 8 December 2012, FCCC/CP/2012/8/Add.1 (2013), Decision 3/CP.18, Approaches to address loss and damage associated with climate change impacts in developing countries that are particularly vulnerable to the adverse effects of climate change to enhance adaptive capacity, art 7(a)(vi).

517 UNFCCC Report of the Conference of the Parties on its nineteenth session, held in Warsaw from 11 to 23 November 2013 FCCC/CP/2013/10/Add.1 (2014), Decision 2/CP.19, Warsaw international mechanism for loss and damage associated with climate change impacts, at [1]-[2]. 
understanding of the substantive and procedural aspects of self-determination in the circumstances, and vice versa. This is because migration is a means of climate change adaptation ${ }^{518}$ but also puts at risk the enjoyment of self-determination if migration is the primary or only solution. ${ }^{519}$ It is possible, therefore, to interpret each area of law in light of the other. Doing so is consistent with art 31(3)(c) of the Vienna Convention on the Law of Treaties (VCLT), which provides that "[t]here shall be taken into account ... any relevant rules of international law applicable in the relations between parties." It is also consistent with the principle of harmonisation, according to which, "when several norms bear on a single issue, they should, to the extent possible, be interpreted so as to give rise to a single set of complete obligations." 520

Some actors have begun reading self-determination into climate law's adaptation and loss and damage aspects. The Task Force on Displacement has reported that participants to a workshop called for "community participation when implementation action to avert, minimize and address displacement ... [that] should be anchored in communities' right to self-determination." ${ }^{521}$ Also, the UN High Commission for Refugees' (UNHCR) Guidance on Protecting People from Disasters and Environmental Change through Planned Relocation (Guidance on Planned Relocation) states that "any measures put forward to affected communities should respect their rights to self-determination". ${ }^{522}$ This guidance is intended to contribute towards UNFCCC-related work on relocation as an adaptation strategy. In the wake of these acknowledgements of the issue, the following discussion seeks to invert the process and use climate law to add more detail to the norm of self-determination in the low-lying States' circumstances.

\footnotetext{
518 Chapter 1, Part 1.

519 Chapter 1, Part III(A).

520 The International Law Commission describes this as "The principle of harmonization": ILC Fragmentation of International Law: Difficulties arising from the Diversification and Expansion of International Law [2006] vol II, pt 2 YILC 175 at 178. See also Questions of Mutual Assistance (Djibouti v France) (Judgment) [2008] ICJ Rep 177 at 219. In a similar, though more expansive, approach, McLachlan refers to this as "systemic integration": Campbell McLachlan "The Principle of Systemic Integration and Article 31(3)(C) of the Vienna Convention" (2005) 54 ILQC 279.

521 Task Force on Displacement "Task Force on Displacement Stakeholder Meeting: Recommendations for integrated approaches to avert, minimize and address displacement related to the adverse effects of climate change" (Meeting Report, Bogis-Bossey, Switzerland, 14-15 May 2018) in Task Force on Displacement, above n 82, Annex VI, 54 at 62.
}

522 UNHCR, above n 104, at [31]. 
The most important element of climate law in terms of adaptation is art 7 of the Paris Agreement. Three important paragraphs of art 7 are worth setting in long-form:

5. Parties acknowledge that adaptation action should follow a country-driven, genderresponsive, participatory and fully transparent approach, taking into consideration vulnerable groups, communities and ecosystems, and should be based on and guided by the best available science and, as appropriate, traditional knowledge, knowledge of indigenous peoples and local knowledge systems, with a view to integrating adaptation into relevant socioeconomic and environmental policies and actions, where appropriate.

6. Parties recognize the importance of support for and international cooperation on adaptation efforts and the importance of taking into account the needs of developing country Parties, especially those that are particularly vulnerable to the adverse effects of climate change.

7. Parties should strengthen their cooperation on enhancing action on adaptation, taking into account the Cancun Adaptation Framework, including with regard to:

(d) Assisting developing country Parties in identifying effective adaptation practices, adaptation needs, priorities, support provided and received for adaptation actions and efforts, and challenges and gaps, in a manner consistent with encouraging good practices; and

(e) Improving the effectiveness and durability of adaptation actions.

Breaking this down, art 7(5) stipulates that third Parties' support and cooperation for vulnerable States should be carried out in a way that follows "a country-driven ... approach". This is comparable to a "self-determined approach" and reflects a substantive aspect of self-determination, which is a people's freely determined economic, social and cultural development, ${ }^{523}$ as well as the procedural aspect of autonomy. ${ }^{524}$

Article 7(5) also provides guidance about other procedural aspects of self-determination. Generally, procedural aspects involve democratic processes that enable peoples to freely determine their political status, and their economic, social and

523 Chapter 2, Part VII(A)(4).

524 Chapter 2, Part VI(B)(3). 
cultural development, as per common art 1(1) of the 1966 Covenants. ${ }^{525}$ Adaptation measures invariably relate (directly or indirectly) to economic, social and cultural development, as art 7(5) recognises when referring to "integrating adaptation into relevant socioeconomic and environmental policies and actions". As well as relating to development, States recognise that adaptation measures should follow a genderresponsive, participatory and fully transparent approach. States also acknowledge that adaptation measures should take into consideration vulnerable groups and communities, and be based on and guided by traditional knowledge, knowledge of indigenous peoples and local knowledge systems. With respect to a low-lying people's relocation enterprise, these elements of the Paris Agreement provide broad guidance on what data collection is required and how it should be collected before relevant decisions are finalised; that is, whether to move, where to go, and how relocation and resettlement will take place.

Article 7(5) also indicates how third-party States might support low-lying States, that is, in the collection and analysis of these data sets. As a whole, art 7(5) seeks to embed an approach to adaptation, and international support for adaptation, in which local people lead and design. This strongly aligns adaptation law with the right to self-determination. This is especially relevant to low-lying States where whole peoples are the beneficiaries of this provision.

In art 7(6), "Parties recognize the importance of support for and cooperation on adaptation efforts and the importance of taking into account the needs" of particularly vulnerable countries, such as low-lying States. Two needs are especially relevant. The first is low-lying States' ongoing capacities to enable their peoples' right to self-determination. ${ }^{526}$ The second need is their continued viability as States, or at least their freely-determined decision to change or forsake that legal personality. Thus, in terms of third-party States' roles, these may entail "support for and international cooperation on" low-lying peoples' endeavours to secure self-determination and their States' continuity ex situ.

\footnotetext{
525 Chapter 2, Part VII(B).

526 This Chapter, Part VII(A).
} 
Article 7(7)(d) bolsters this conclusion, clarifying that developing country Parties identify their own adaptation needs and practices, with the assistance of other Parties. Article 7(7)(e) is also relevant because effective and durable solutions that reflect good practice must include measures that protect the right to self-determination itself, as well as other human rights and international peace and security, for all of which self-determination is foundational. ${ }^{527}$ Adaptation actions will not be effective or durable if they undermine a people's enjoyment of self-determination.

Within the ambit of the UNFCCC, but outside the Paris Agreement, the non-binding COP 16 decision establishing the Cancun Adaptation Framework invited Parties to enhance action on adaptation by undertaking "[m]easures to enhance understanding, coordination and cooperation with regard to climate change induced displacement, migration and planned relocation, where appropriate, at the national, regional and international levels". ${ }^{528}$ Bilateral and multilateral efforts conducted in these ways would be consistent with self-determination, since "understanding", "coordination" and "cooperation" each imply respect for low-lying States' autonomy and their peoples' right to freely determine their political status, and economic, social and cultural development. In practice, this would involve dialogue among countries with a view to better understanding needs and aspirations, and to devising policies and measures in light of that data. Nonetheless, the low-lying States' right to leadership in decision-making is embedded in the language.

This is not the case in the Task Force on Displacement's recommendations for Parties, which resemble orthodox migration pathways. ${ }^{529}$ Parties are invited to: ${ }^{.30}$

Facilitate orderly, safe, regular and responsible migration and mobility of people, as appropriate and in accordance with national laws and policies by considering the needs of migrants and displaced persons, communities of origin, transit and destination, and by

\footnotetext{
527 Chapter 2, Part (VI)(A).

528 Cancun Adaptation Framework, above n 10, at [14](f).

529 Task Force on Displacement, above n 82, at [33]

530 At $[33(\mathrm{f})]$.
} 
enhancing opportunities for regular migration pathways, including through labour mobility, consistent with international labour standards, in the context of climate change.

While the Task Force on Displacement focuses on migration, it will be important for States to consider the impacts of their approaches to relocation on low-lying peoples' enjoyment of self-determination. Seeking to enable that right ex situ will require a more comprehensive programme of policies and activities than, say, enhanced access to labour mobility schemes. That said, such schemes may offer a non-controversial starting point for entering this policy area.

\section{Potential Obstacles to Low-Lying States' Ex Situ Self-Determination}

Self-determination is a fundamental principle of public international law, and the rights-holders can be clearly identified, but critical challenges remain. The lack of any obligatory duty-bearing third-party States is a critical first barrier, along with the potential for peoples' fragmentation. ${ }^{531}$ There are four other major challenges and risks to low-lying peoples' ex situ self-determination that will be discussed in this part: the lack of precedent and concrete guidance; the lack of specificity in current self-determination law; the probability of third-party States accepting climate migrants only as minorities, not peoples; and the imbalance of power between a low-lying people's self-determination against a potential partner State's enjoyment of other international norms, such as territorial integrity. Nevertheless, given its importance for human rights, peace and security, and protection for culture and ways of life, it is important to navigate the policy challenges and recognise that they are not insurmountable. The options presented in chapter 5 illustrate the possibilities for resolving these challenges.

The first obstacle to ex situ self-determination is the lack of precedent or guidance for applying the right to the situation affecting low-lying States. Existing instruments of public international law were not drafted with anything comparable to this climate change scenario in mind. However, work on relocation is now being carried out by the UN via

531 This Chapter, Parts II(B)(3) and II(C)(1). 
its Economic and Social Commission for Asia and the Pacific ${ }^{532}$ and the IOM, ${ }^{533}$ as well as the Executive Committee on Loss and Damage, ${ }^{534}$ the Task Force on Displacement, ${ }^{535}$ the ILA, ${ }^{536}$ and the Platform on Disaster Displacement, ${ }^{537}$ and now by some individual States, such as Fiji ${ }^{538}$ and Vanuatu. ${ }^{539}$ These initiatives are making critical observations and progress, but are developing policies from orthodox migration paradigms. Consequently, self-determination is overlooked. New Zealand's action plan is an exception in this regard, with its "core value" of respecting this right. ${ }^{540}$ Also, Fiji's relocation guidelines, while not referring to self-determination, are aspirational. They are intended for internal climate migration primarily, but the guidelines refer to a "regional approach" to cross-border movement that involves: ${ }^{541}$

\footnotetext{
... bringing domestic policies in accordance with regional existing norms in order to strengthen the societal values and traditions specific to all regions in the world and to address the need for an inclusive approach for all stakeholders, including civil society, and [based] upon the relevance of "pre-existing cultural and social beliefs about the roles, functions, responsibilities and social standing of different groups within societies, and resulting practices".
}

This passage appears to be consistent with individuals' right to culture, but it is not guaranteed to extend to a people's right to self-determination. States and communities would be supported if specific proposals for addressing this right were included in the ongoing development of guidelines for climate-related relocation.

UNESCAP "Pacific Climate Change and Migration Project" <www.unescap.org>.

IOM, above $\mathrm{n} 87$.

UNFCCC, above $\mathrm{n} 82$.

Task Force on Displacement, above n 82.

ILA Committee on International Law and Sea Level Rise, above n 54.

Platform on Disaster Displacement, above n 405.

Ministry of Foreign Affairs and International Cooperation (FJ), above n 394.

Vanuatu National Disaster Management Office National Policy on Climate Change and DisasterInduced Displacement (2018).

CAB-18-MIN-0218, above n 90, at [23].

Ministry of Economy (FJ), above n 46, at 9 (emphasis in original). 
A second challenge is that, even if a third-party State volunteers to partner in the relocation enterprise, its rights and duties as currently understood only offer general directions. ${ }^{542}$ The consequent risk is minimal compliance, which is unlikely to suffice to protect the right. However, self-determination can, and arguably should, underpin the relocation enterprise. It imposes obligations erga omnes and is arguably a jus cogens norm, and it is a continuing right for all peoples with both procedural and substantive obligations for a partner State.

The third risk is the probability that partner States may be inclined to characterise low-lying islanders as immigrants and minorities, rather than as a people. As noted previously, this is very likely if there is not a legal framework that acknowledges the people's right to self-determination ex situ and they are peoples fragmented by opportunistic migration schemes. If this is the case, the partner State would comply with international obligations via minority protections, which may be achieved by relying on existing laws. For example, New Zealand could rely on existing non-discrimination and minority rights protections in its Bill of Rights and Human Rights Acts. ${ }^{543}$ While such protections are essential, they are lower standards than self-determination. ${ }^{544}$ To mitigate this risk, low-lying States will need to assert themselves repeatedly as peoples and have this status recognised regionally or internationally.

Arguably the major risk to low-lying peoples' ex situ self-determination will be the rights of third-party States. McAdam explains: ${ }^{545}$

Ultimately, the principle of self-determination must give way to territorial integrity and State sovereignty, such that no State has a claim on another to cede territory in order to permit its continued existence.

Moreover, no State has a claim on another to forsake any degree of internal jurisdiction, which is the effect of agreeing to a low-lying people's internal

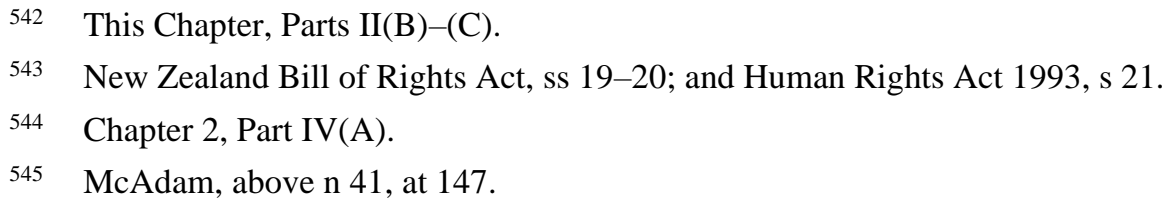


self-determination and the corollary degree of autonomy. Again, it should be recognised that low-lying peoples have the right to self-determination and to its substantive and procedural entitlements. ${ }^{546}$ Promoting and respecting the legal right to self-determination requires recognising the rights of all groups that are entitled to be politically self-determining. ${ }^{547}$ Furthermore, decision-makers have available a range of methods for satisfying low-lying peoples' ex situ self-determination, which can ameliorate some of the partner States' concerns, and which are discussed in chapter 5. Even accounting for these factors, it is still true that the low-lying peoples' ability to relocate and retain self-determination ex situ will depend heavily on the good will of partner States, the oversight and support of third-party States and international agencies, and the incentives that can be devised and availed to the partner States.

In addition to the challenges described in this part, there is the plethora of practical matters in terms of land availability, ${ }^{548}$ communities' access to government assistance, ${ }^{549}$ loss of cultural and spiritual 'assets', ${ }^{550}$ and more. ${ }^{551}$ In Pascoe's case study of the Tulun people introduced earlier, she found unsurprisingly that "achieving self-determination in cases of climate change migration is complex and difficult", requiring "both community participation in decision-making and practical and financial support." 552 Overall, the challenges to ex situ self-determination are vast, but the right does not need to be enjoyed in the future in the same way as low-lying peoples enjoy it today. There is a range of means, which have precedent, and which will be discussed in chapter 5 . This provides flexibility for policy-makers to resolve these challenges.

\footnotetext{
46 Chapter 2, Part VII.

547 Buchanan, above n 169, at 470.

548 Pascoe, above n 61, at 85.

549 At 80.

550 At 79.

551 Chapter 1, Part II.

552 At 85.
} 


\section{Concluding on and Synthesising All Self-Determination Elements}

The peoples of low-lying States have a right to self-determination, and this right encompasses a bundle of derivative rights, both substantive and procedural. Maintaining self-determination ex situ would support the right's objectives of promoting international peace and security, and enabling the other human rights. However, in this respect low-lying States are the only actors with clear obligations in international law regarding their peoples' self-determination.

There exist general duties on all States regarding all peoples' self-determination. However, these lack the specificity that would give low-lying peoples confidence they will receive adequate international support for their ex situ enjoyment of the right. There are existing and historical relationships that point towards logical options for potential partner States, but no legal pathways for developing such choices. Therefore, all things considered, the OHCHR's conclusion that "States have a duty to take positive action, individually and jointly" ${ }^{153}$ belies the fact that the duties are generic, ambiguous and, in the current state of affairs, apply to no States in particular, except the low-lying States themselves.

Moreover, there are significant obstacles to overcome to even bring those generic duties to bear. A third-party State deciding whether to become a partner State will face (or avoid) a significant policy decision. There may be benefits, such as supporting the international rules-based order. However, the costs of facilitating a separate people's self-determination and being an innovator in an unprecedented situation may be considerable, especially in comparison to accepting people as simple migrants with orthodox minority protections.

It is inappropriate to speak on behalf of the peoples of low-lying States who are forced to relocate, but in pragmatic terms, they will likely need to respond to the concerns of potential partner States. For instance, they may need to develop new ways to enjoy 
self-determination, to protect their community and its distinct character, to develop institutions that enable their norms, and to effectuate autonomy from other political units. Although formidable, this may be feasible. In a different context, Berlin has made the following informative observations: ${ }^{554}$

\begin{abstract}
What oppressed classes or nationalities, as a rule, demand is neither simply unhampered liberty of action for their members, nor, above everything, equality of social or economic opportunity, still less assignment of a place in a frictionless, organic State devised by the rational lawgiver. What they want, as often as not, is simply recognition (of their class or nation, or colour or race) as an independent source of human activity, as an entity with a will of its own, intending to act in accordance with it (whether it is good or legitimate, or not), and not to be ruled, educated, guided, with however light a hand, as being not quite fully human, and therefore not quite fully free.
\end{abstract}

While it is possible to imagine ways to facilitate this important source of human activity, the costs for third-party States will remain challenging, and the low-lying peoples will need to adjust their ways of life. However, it remains important that the relocation enterprise is underpinned by self-determination to avoid the human rights problems known to result from the deprivation of this right. Key aspects of self-determination should be borne in mind: its objectives; the entitlements it creates; and the general corresponding duties. States which offer to partner in this endeavour should do so understanding that it imports a duty to work with the low-lying States, and the UN and its organs and agencies. This will involve defining what self-determination means for each party in practice in this new relationship, for example, the extent of procedural rights, the types of mechanisms for enabling peoples to "freely determine their political status and freely pursue their economic, social and cultural development", ${ }^{555}$ and how their normative systems dovetail with one another.

The relevant powers and duties of the UN and other States should also be acknowledged. Particularly helpful in this regard will be assistance for, and scrutiny

\footnotetext{
554 Isaiah Berlin "Two Concepts of Liberty" in Isaiah Berlin Four Essays on Liberty (Oxford University Press, Oxford, 1969) at 23.

555 Resolution 1514, above n 208.
} 
regarding, how the partner State enables the low-lying peoples' self-determination, including ensuring "a free and genuine expression of the will of the peoples concerned", 556 which is given due regard ${ }^{557}$ and reflected in governance institutions. ${ }^{558}$ Third-party States must also refrain from interfering in the self-determination of low-lying States, which has implications for statehood continuity, as will be discussed in chapter 4 .

Self-determination does not demand the same existence and the same degree of political independence as the low-lying States enjoy now. ${ }^{559}$ This conception of full autonomy may be a useful starting point for low-lying States to negotiate a maximum degree of autonomy, but third-party States' competing interests will force compromises. As will be discussed in chapter 5, there are many ways of effectuating this collective right, which may accommodate both States' interests. Overall, self-determination is a legal and political device that has the potential to inform and enhance the development of options for the protection of peoples displaced from low-lying states by climate change and other drivers, but it is by no means a panacea. To make it effective, States must adopt self-determination as an explicit basis for a relocation agreement and programme, and an ethos of partnership and good will. If the aspects of self-determination set out here are ignored or downplayed, the risks to the peoples of low-lying States is that they will be deprived of their right to self-determination and endure the losses that follow.

\footnotetext{
556 Western Sahara, above n 255, at 32.

557 At 33 .

558 Brownlie, above $\mathrm{n} 335$, at 107-108.

559 Ödalen, above n 139, at 233.
} 


\section{Chapter 4: Statehood Continuity}

\section{Introduction}

In accordance with their right to self-determination, low-lying peoples have the right to freely determine their political status. The political status they currently enjoy is statehood, as affirmed by their being Member States of the UN. ${ }^{560}$ According to the "presumption of continuity of statehood", ${ }^{561}$ these States have "a fundamental right to ... survival". ${ }^{562}$ However, their ongoing statehood is challenged by the climate change scenario. Article 1 of the Montevideo Convention provides that the traditional indicia of statehood are a permanent population, a defined territory, government, and capacity to enter into relations with other states. The adverse effects of climate change could result in low-lying States losing their permanent populations and their defined territories. Thus, the issue is whether, in the case of an extant State, the presumption of continuity of statehood and the right to self-determination take primacy over the Montevideo indicia such that any failure to satisfy those indicia does not function as a legal milestone resulting in the termination of statehood. The analysis here finds that statehood is not automatically terminated if low-lying States cease to satisfy those indicia. The next chapter explores how ex situ statehood might be continued in another State's territory.

Some analysts who have evaluated the impacts of climate change have focused on the Montevideo indicia and concluded that statehood would be lost. The analysis here focuses instead on the existence and function of the presumption of continuity and on its relationship with the right to self-determination. It also discusses the Montevideo indicia, looking at the far-reaching flexibility in how they may, or may not, be satisfied for extant States. It finds that this amenability is further evidence of the primacy of the presumption of continuity and the right to self-determination.

560 All of the low-lying States - Kiribati, the Maldives, the Marshall Islands, and Tuvalu - are Member States of the United Nations: United Nations "Member States" <www.un.org>.

561 UNHCR, above n 104, at [30].

562 Legality of the Threat of Nuclear Weapons (Advisory Opinion) [1996] ICJ Rep 226 [Nuclear Weapons] at 263. 
This chapter is structured as follows. Part II reviews the importance of statehood generally and to the low-lying States. Part III summarises previous literature on the statehood question. Part IV explains the presumption of continuity, the authority for its role in international practice, and how it applies. Part V examines the relationship between the presumption and the right to self-determination for low-lying States. Part VI looks at the relationship between the presumption and the Montevideo indicia. Part VII looks at the issue of recognition by third-party States.

\section{The Importance of Statehood}

Statehood is the pre-eminent means of effectuating self-determination. There are other legal personalities that can support a people's external and internal self-determination, which are considered in the next chapter, but statehood demands special attention. As Shaw identifies, "states remain by far the most important legal persons ... [and] retain their attraction as the primary focus for the social activity of humankind and thus for international law." ${ }^{563}$ Losing statehood would have extensive ramifications for low-lying peoples.

There are actors in addition to States that have international legal personality, including international and regional organisations, sui generis entities (such as the Order of Malta), ${ }^{564}$ multinational corporations, and individuals. ${ }^{565}$ However, traditional legal theory holds that States remain the key actors in international law, and enjoy a range of exclusive rights and privileges. Notably, "[e]very State possesses capacity to conclude treaties" ${ }^{156}$ and states are the primary law-makers and primary subjects in international

563 Shaw, above $\mathrm{n} 91$, at 143.

564 Regarding the Order of Malta, see Chapter 5, Part II(C)(3).

565 Crawford, above n 91, at 116-125; Martin Dixon, Robert McCorquodale and Sarah Williams Cases \& Materials on International Law (5th ed, Oxford University Press, Oxford, 2011) at 132-133; and Shaw, above n 91, at 143.

566 VCLT, art 6. Crawford expands: "States have plenary competence to perform acts, make treaties, and so on, in the international sphere: this is one meaning of the term 'sovereign' as applied to States": Crawford, above n 169, at 40. 
law. ${ }^{567}$ Other subjects of international law derive their personality from States, ${ }^{568}$ and their rights and duties are, therefore, limited compared to States.

States are equal and sovereign. ${ }^{569}$ The Montevideo Convention explains: $:{ }^{570}$

States are juridically equal, enjoy the same rights, and have equal capacity in their exercise.

The rights of each one do not depend upon the power which it possesses to assure its exercise, but upon the simple fact of its existence as a person under international law.

Additionally, only States may be admitted membership to the UN, ${ }^{571}$ and only States may be parties to the Statute of the ICJ and brings claims to that Court. ${ }^{572}$ Statehood also endows the entity with exclusive jurisdiction for regulatory authority within its territory, which includes the powers to create and enforce laws, ${ }^{573}$ and which extends to States' territorial seas. ${ }^{574}$ It is also "the inalienable right of all States to dispose of their wealth and natural resources in accordance with their national interests". 575 Moreover, statehood endows heads of State and senior State officials with international privileges and immunities. ${ }^{576}$ States are deemed entitled to these rights by virtue of their statehood. ${ }^{577}$ Conversely, these are the rights at stake if low-lying States have that status terminated. 
As well as special rights and privileges, States also have unique obligations, including those regarding human rights. Of particular importance to this thesis, States have obligations regarding the right to self-determination. The low-lying States are the principal duty-bearers with respect to this norm, which further emphasises the importance of maintaining their statehood status. A partner State that welcomes a low-lying people as a people, not a minority, will also have obligations regarding that people's self-determination.

\section{Prior Analyses of the Statehood Question}

As noted at the start of this chapter, the orthodox indicia of statehood are a permanent population, a defined territory, government, and capacity to enter relations with other states. ${ }^{578}$ In a climate change context, some analysts have suggested that statehood will be extinguished when low-lying States no longer satisfy one or more of these indicia.

Craven's analysis on the general possibility of statehood termination seems to have set a tone that has been followed by other scholars looking into the low-lying States' circumstances. ${ }^{579} \mathrm{He}$ recognises the presumption of continuity of States and that "states are not in the habit of withdrawing recognition from entities once established". 580 Nevertheless, Craven concludes that: ${ }^{581}$

Assuming that international law does possess certain criteria that condition the 'existence' of the state, or at least its participation in the legal community, then logically those criteria should also apply as regards its 'legal demise'. Thus, the general criteria for statehood ... should presumably govern not merely the legal 'creation' of states, but also their 'extinction'. So, where the territory of a state becomes submerged by the sea, or where the population of

578 Montevideo Convention, art 1.

579 Matthew CR Craven "The Problem of State Succession and the Identity of States under International Law" (1998) 9 EJIL 142.

580 At 159.

581 At 159. See also Anzar-Gómez, above n 255, at 30. 
a state evacuates en masse to other territories, or where it falls into a state of extended anarchy, it should be possible to conclude that the state has ceased to exist.

The appealing straightforwardness of Craven's analysis, and the fact that he uses the low-lying States' scenarios as an example, has led others to follow suit. For example, Rayfuse says, "[a]s the territory of a threatened island State disappears beneath the waves, the criteria of territory will no longer be met and the claim to statehood will fail" because territory is a "fundamental" requirement of statehood. ${ }^{582}$ Similarly, Atapattu says, "[t]he [Tuvaluan] islanders will become stateless persons in every sense of the word." ${ }^{83}$ The UN Secretary-General has followed many others in describing climate change as "an existential threat", adding that Tuvalu is "fighting to preserve its very existence." ${ }^{284}$ Although such language may only be used as a political device to promote global ambition on climate action, it may have the perverse effect of creating opinio juris that has the impact which low-lying States are looking to avoid. This is an unnecessary risk, as will be demonstrated.

The premise of Craven's conclusion and the statements that followed is doubtful. Craven presents no unimpeachable logic for why the same set of conditions for establishing States should be presumed necessary for their continuity. The presumption of continuity, the right to self-determination and the contemporary exceptions to satisfying the indicia all indicate that this logic is over-simplified, as will be discussed.

There are more solid foundations in premising the statehood analysis on an assumption that territory is fundamental. The 1648 Peace Treaty between the Holy Roman Empire and the King of France and their respective Allies (the Treaty of Westphalia) is often considered the milestone development in consolidating the sovereign

582 Rayfuse, above n 92, at 284.

583 Sumudu Atapattu "Climate Change, Human Rights, and Forced Migration: Implications for International Law" 27 Wisconsin Int'l L J 607, 2009-2010, at 635.

584 UN News, above n 108. See also SPC "Atoll nations unite against the exceptional and existential threat caused by climate change" (15 May 2019) <www.spc.int>. 
State as a positive legal entity. ${ }^{585}$ Since then, the State has been "based on the principles of autonomy, territory, mutual recognition and control".586 Thus, conceptually, the centrality of territory in orthodox conceptions of the State is perhaps the primary reason for doubting whether low-lying States can continue ex situ.

Despite the apparent strength of this argument, other assessments remain cautious, even if leaning in a similar direction to Craven, Rayfuse and Atapattu. The General Assembly has recognised that "the effects of climate change may threaten the very existence of some [small island developing States]"; ${ }^{587}$ a guarded conclusion shared by the UNHCR and Shaw. ${ }^{58}$ The Asian Development Bank notes that loss of territory "would put heavy constraints on statehood", but stops short of saying it would be terminated. ${ }^{589}$ For Schrijver, "it is difficult to imagine how international law would recognize the existence of a State without any territory at all", but does not say it is impossible. ${ }^{590}$ And Park recognises the "strong presumption of continuity for established states", but surmises that: ${ }^{.91}$

... the possibility of a total loss of territory for natural reasons or the total displacement of a population and/or government, is entirely novel, and would present a heightened risk of statelessness.

In analysing, or sometimes going beyond the orthodox statehood indicia, others consider the principle of effectiveness, that is, "an entity is only a state when certain (24 October 1648) [Treaty of Westphalia]; and Leo Gross "The Peace of Westphalia, 1648-1948" 42(1) AJIL 20 at 20. For a wider discussion, see Crawford, above n 169, at 6-12.

586

Stephen D Krasner "Rethinking the sovereign state model" (2001) 27 Review of International Studies 17 at 17.

Follow-up to and implementation of the Mauritius Strategy for the Further Implementation of the Programme of Action for the Sustainable Development of Small Island States GA Res 63/213, A/Res/63/213 (2009) at preamble, sixth recital (emphasis added). Fastenrath and others (eds) From Bilateralism to Community Interest: Essays in Honour of Judge Bruno Simma (Oxford University Press, Oxford, 2011) 1278 at 1284-1285.

591 Park, above n 28, at 3-4. 
factual conditions are met - a purely empirical check." ${ }^{192}$ Regarding the creation of States, Ryngaert and Sobrie view effectiveness as central to the Montevideo Convention. ${ }^{593}$ Stoutenburg also relies on effectiveness and considers "territorial effectiveness".594 She concludes that "uninhabitable land does not qualify as State territory"595 and, therefore, "the island State would cease to satisfy the territorial prerequisite for statehood once an uninhabitable piece of land was the only terra firma left." ${ }^{596}$ Her reasoning is teleological: the eventuality of uninhabitable territory would undermine statehood since territory is not an end in itself, but a means to an end, that is, where effectiveness enables organised communities. ${ }^{597}$ Stoutenburg recognises that the principle of legality "possessing the insignia", rather than the "actual authority" of effectiveness ${ }^{598}$ - takes precedence when there is a breach of a jus cogens norm. ${ }^{599}$ However, she finds that a breach does not result from greenhouse gas emissions, nor climate change, nor its impacts on low-lying States, thereby leaving the principle of effectiveness as key. ${ }^{600}$

These analyses have given little attention to the presumption of continuity and omitted the role of self-determination in questions of statehood continuity. It is submitted, therefore, that the legal analysis is incomplete and conclusions premature. The remainder of this chapter will argue that statehood is not, and perhaps cannot be terminated by the loss of any of the Montevideo indicia because of the presumption of continuity, and its relationship with self-determination and with the Montevideo indicia. Practice of Recognition in the Wake of Kosovo, South Ossetia, and Abkhazia" (2011) 24(2) LJIL 467 at 472. But see Crawford, above n 169, at 55-61, who gives less weight to the role for effectiveness than Ryngaert and Sobrie.

593 At 472.

594 Stoutenburg, above n 127, at 60 .

595 At 61. More recently, it has been determined that art 121(3) does not require that an island only needs to be capable of being inhabited; not actually inhabited: In the matter of the South China Sea Arbitration (Republic of the Philippines v People's Republic of China) (Award) [2016] PCA Case No 2013-19 [South China Sea Arbitration] at [483].

596 Stoutenburg, above n 127, at 61-62.

597 At 61 .

598 At 58 .

599 At 59 and $74-75$.

600 At 72-75 and 79-85, referring to the Draft articles on State Responsibility, above n 118, arts 40-41. 


\section{The Presumption of Continuity}

The ICJ has recognised "the fundamental right of every State to survival". ${ }^{601}$ This right is referred to more often as "the presumption of continuity", ${ }^{602}$ which is shorthand for the UNHCR description: "a general legal presumption of continuity of statehood and international legal personality under international law". ${ }^{603}$ The presumption provides that, once this international legal personality is established, States have "complete and permanent sovereignty"; ${ }^{604}$ that is, "State failure does not extinguish statehood". ${ }^{605}$ More colourfully, Kreijen explains that "States may have a complicated birth, but they do not die easily". ${ }^{606}$ The presumption's provenance dates back to at least the 1923 Tinoco Claims Arbitration, in which Arbiter Taft recognised the "principle of the continuity of states". ${ }^{607}$ No State has needed to rely on the presumption of continuity in a situation involving the loss of its entire permanent population and habitable territory to environmental disaster. Nor has any State been terminated in circumstances analogous to the low-lying States' relocation scenarios. Therefore, the issue is whether the presumption of continuity applies to States that lose all habitable territory and a permanent resident population. The conclusion here is the presumption of continuity should apply to the low-lying States' loss of territory scenarios. Existing law and practice

John Bassett Moore Digest of International Law: Volume 1 (U.S. Government Printing Office, 1906) at 249, cited with approval in Tinoco Claims Arbitration (Great Britain v Costa Rica) (Arbitral Awards) (1923) 1 UN Rep Intl Arb Awards 369 at 377. 
have no legal milestone nor any mechanism for exogenous forces to terminate statehood; only to presume its continuity.

Of all the Montevideo indicia, the presumption of continuity relates primarily to government; that is, States continue even though governments come and go, and there may be periods where there is no government while elections are being decideds. ${ }^{608}$ In such cases, continuity is a manifestation of a functionally-necessary distinction between governments and States in certain, mostly benign situations.

The presumption also applies in more challenging situations, such as governmentsin-exile or where lengthy civil wars affect governmental capacity. ${ }^{609}$ Thus, the presumption applies even where there is "prolonged lack of effectiveness". ${ }^{610}$ Grant has found that established States have not lost their statehood when control over their territories has been lost, as in cases of annexation (during World War II) and civil strife (in Somalia) ${ }^{611}$ Crawford summarises the practice regarding continuity as follows: ${ }^{612}$

\begin{abstract}
A State is not necessarily extinguished by substantial changes in territory, population or government, or even, in some cases, by a combination of all three. ... Extinction is not effected by more-or-less prolonged anarchy within the State nor, within equally broad limits, by loss of substantial independence, provided that the original organs of the State remain formally separate and retain at least some semblance of control.
\end{abstract}

This aligns with Werner and De Wilde's conclusion about rules for terminating sovereignty. In discussing similar cases, they find that any rules regarding such termination are not about "brute facts": 613

608 Crawford, above n 169, at 34. See also Shaw above n 91, at 330: "recognition of a government has no relevance to the establishment of new persons in international law". See also Park, above n 28, at 3.

609 Crawford, above n 169, at 34

610 At 132.

611 Thomas D Grant "Defining Statehood: The Montevideo Convention and its Discontents" (1999) 37 Colum J Transnat'1 L 403 at 435.

612 Crawford, above n 169, at 700-701.

613 Wouter G Werner and Jaap H de Wilde "The Endurance of Sovereignty" (2001) 7(3) European Journal of International Relations at 296. 
A state does not cease to exist merely because it is no longer able to exercise effective control in situations of civil war or foreign occupation. ... It is difficult to join the league of sovereigns, but once inside, it is also difficult to be ousted.

Two common facts stand out among these various situations in which continuity has applied, which distinguish them from the low-lying States' circumstances. First, any risks to statehood have related ultimately to the indicia of government, even if that extends to losing effective control over territory or population. Secondly, the situations were illegal, temporary, or both. By contrast, the low-lying States' risks relate to their permanent populations and their territories, and the impacts could be permanent.

However, the situations in which State extinction has occurred can also be distinguished readily from the low-lying States' scenarios. Rules relating to States' endings relate to entirely unrelated circumstances: succession in decolonisation; dismemberment of an existing state; secession; merger; and, historically, annexation. ${ }^{614}$ In all those situations, sovereignty is inherited by another; "[t]here is never simply a void", as McAdam explains. A rights void is the implied consequence with so-called "disappearing States". 615

The low-lying States' situations are also distinguishable from prior extinctions on the basis that those historical entities were ephemeral or their extinctions voluntary. Crawford explains that: ${ }^{616}$

... there is a strong presumption against the extinction of States once firmly established. It is significant that almost all the cases of extinction ... involved either entities that were ephemeral or whose independence was not clearly established or were instances of voluntary extinction, when a people (as in the case of the GDR [German Democratic Republic]) or their representatives (as in the case of Czechoslovakia) decided to put an end to their State and to opt for a different future.

614

615

616

Shaw, above n 91, at 694 .

McAdam, above n 41, at 127; and see Crawford, above n 91, at 151; and Adam Tooze "Rising Tides Will Sink Global Order" (20 December 2018) Foreign Policy <foreignpolicy.com>.

Crawford, above n 169, at 715. See also Shaw, above n 91, at 151. 
The low-lying States are not ephemeral entities, their independence is thoroughly established, and they are not volunteering to end their States and opt for a different future - quite the opposite. Therefore, the limited situations of statehood extinction bear no resemblance to the low-lying States' scenarios.

Overall, the situations involving both continuity and extinction are very different from the low-lying States' cases. Nevertheless, it is suggested that the presumption of continuity should apply for three reasons. First, there are general reasons for applying continuity to low-lying States: stability; feasibility; and lack of procedure for termination. That is the focus of the remainder of this part. The two other reasons appear in the following two parts if this chapter, namely: the mutually reinforcing relationship between the presumption and the right to self-determination; and the presumption's effects on the Montevideo indicia, which is that they are highly flexible for extant States.

The conservative approach to potential extinction provides certainty in international relations, which reduces the number of international conflicts. ${ }^{617}$ Wong argues that "vague notions such as stability" are, on their own, insufficient for applying continuity to low-lying States. ${ }^{618}$ This is because, Wong claims, "there must be a specific, identifiable reason for the doctrine to apply", otherwise it "would give rise to charges of indeterminacy in respect of the doctrine's limits."619 Wong offers no authority for suggesting there should be specific reasons for applying the presumption of continuity. This is problematic given the wide variety of factual situations in which the presumption has applied, from regular situations of interregna between governments through to fragile States; all of which have the effect of promoting stability. Given the rights and responsibilities of States outlined earlier in this chapter, claiming that stability is merely a "vague notion" seems oversimplified.

Derek Wong "Sovereignty Sunk? The Position of Sinking States at International Law" (2013) 14 Melbourne Journal of International Law 1 at 33.

619 At 33 
Furthermore, continuity is not a vague notion if it is practically feasible. Just as it is possible for statehood to survive through situations of anarchy or attempted annexation, it is possible for it to survive relocation. Wong suggests that low-lying States may be established ex situ as "a legal fiction - so as to achieve the protection of an international legal rule", but finds this idea functionally problematic. ${ }^{620}$ However, Burkett proposes a practical alternative: her "Nation Ex Situ" proposal. ${ }^{621}$ This is based on the presumption of continuity, the flexibility of the legal concept of statehood, and lessons from precedented alternative forms of statehood, for example, governments-in-exile. ${ }^{622}$ Crucially, Burkett's Nation Ex Situ also involves a proposal for diasporic cosmopolitanism. This model involves geographically dispersed diaspora populations who are citizens of a deterritorialised State, which serves as the people's political and cultural nucleus, and which is supported by a reinvigorated UN Trusteeship system. ${ }^{623}$ Burkett's solution remains the stand-out proposal for relocating low-lying peoples, although there would be significant policy work for both low-lying and partner States to undertake such an endeavour. Chapter 5 illustrates some further ways in which self-determination can be maintained ex situ, including additional mechanisms that can support statehood.

Another source of evidence for the importance of continuity to the international order and, therefore, why low-lying States' statehood should enjoy the presumption, is that there is no process for terminating that legal personality and leaving a void. Therefore, proposing to terminate a current State invokes questions, including:

- Is the UN General Assembly required to revoke a low-lying State's membership?

- How would this happen? There is a "lack of any general procedure for derecognition". ${ }^{24}$ The only mechanism for expelling Members does not apply,

620 At 33 .

621 Burkett, above n 105, at 363.

622 At 356-357.

623 At $358-360$ and 363.

624 Paul Taylor "The United Nations in the 1990s: Prospective Cosmopolitanism and the Issue of Sovereignty" (1999) XLVII Political Studies 538 at 558; and see McAdam, above n 101, at 137. 
relating only to where a State has "persistently violated the Principles contained in the ... Charter". ${ }^{625}$ The Charter does not even allow States to extract themselves from the UN, unlike the League of Nations, where countries could have given notice. ${ }^{626}$

- If a procedure was devised, must other international and regional organisations follow the UN's lead and revoke the State's membership?

- Does losing membership of these organisations equate to losing statehood?

- Would third-party States be obliged to withdraw recognition? If so, who has the power to impose this obligation?

- Must individual States renounce bilateral agreements and cease bilateral relations?

- Would acquiesce to the situation by third-party States be enough to terminate a low-lying State's statehood?

- How many States must do whatever is required before statehood is affected, not just bilateral relations?

- Is the ICJ competent to make a pronouncement that has the effect of terminating statehood?

- Indeed, since "the principle of consent is a structural principle of international law", ${ }^{627}$ is it possible to create law that seeks to terminate a State's statehood without that State's consent?

None of this seems feasible or workable, which reflects two things: the expectation of statehood continuity; and the resulting fact that there is simply no legal milestone that, if it occurred, would result in the termination of a current State. While it may appear equally difficult to facilitate ex situ statehood, there are practical options, such as Burkett's proposal and those discussed in chapter 5.

625 Charter of the United Nations, art 6.

626 Covenant of the League of Nations 1919, art 1(3).

627 Crawford, above n 169, at 100. See also Andrew T Guzman "Against Consent" (2012) Va J Int'1 L 747 at 748-749; Matthew Lister "The Legitimating Role of Consent in International Law" (2011) 11(2) Chicago Journal of International Law 664 at 666; and Shaw, above n 91, at 7-8. 
In conclusion, there is a presumption — even a "fundamental right" ${ }^{628}$ — that, once established, States continue. Consequently, there are no rules, processes or practice which suggests the presumption does not apply to low-lying States even if they no longer satisfy, in orthodox form, the territory indicia for the creation of States or, in fact, any of the indicia. The presumption of continuity enables stability and, as discussed in the next part, is consistent with the right to self-determination.

\section{The Relationship between the Presumption of Continuity and the Right to Self-Determination}

Questions about the existence of statehood involve the law of self-determination. ${ }^{629}$ Thus, the relationship between these areas of international law is critical to questions about low-lying States' potential ex situ continuity. Chapters 2 and 3 examined the low-lying peoples' right to self-determination in the relocation scenario. One finding was that a substantive entitlement is the peoples' political status, freely determined, which is provided for in common art 1(1) of the 1966 Covenants. ${ }^{630}$ The analysis also considered the concept of external self-determination, which involves establishing, and continuing to be, an independent State in the international community. ${ }^{631}$ Those findings are central to the principal conclusion of this Part, which is that the right to self-determination supports the presumption of continuity.

The earlier self-determination analysis identified elements directly relevant to the question of low-lying States' continuity. ${ }^{632}$ The right to self-determination:

- Belongs to the peoples of low-lying States, not their territories;

- Exists in perpetuity, not just when establishing statehood at decolonisation;

\footnotetext{
628 Nuclear Weapons, above n 562, at 263.

629 Chapter 2, Parts V(A) and VI(B).

630 Chapter 2, Part VII(A).

631 Chapter 2, Part VI(B).

632 Chapter 2, Parts IV(B) and VII(A).
} 
- Is not extinguished automatically due to relocation;

- Entitles low-lying peoples to statehood or other political status determined freely and without external interference; and

- Imposes obligations erga omnes and is probably a jus cogens norm.

It is submitted that the combined effect of these elements is that the low-lying States and their peoples are exclusively competent to extinguish their statehood. Outside attempts at doing so, without unequivocal, voluntary forfeiture by the low-lying peoples, would constitute a breach of their right to self-determination. It would also open the door to all States being susceptible to termination by forces beyond their control, which would be a regressive development in international law since "the nub of self-determination [is] eliminating the imposition of a 'foreign will' upon a people." 633 To prevent exogenous forces from being competent to terminate a State and undermining a people's right to self-determination, continuity of low-lying States must be presumed, even in unprecedented circumstances.

The relationship between self-determination and statehood is not automatic, but the low-lying States' situations are ones in which these principles of international law are related. There are two general sets of circumstances in which self-determination and statehood are conjointly relevant in practice. The most common circumstance is in the creation of new States. ${ }^{634}$ In this regard, Cassese argues that self-determination is "at odds" with Westphalian principles of sovereignty and non-interference, which are intended to "sanction and safeguard the status quo". ${ }^{635}$ This conclusion is flawed insofar as it is too general and overlooks the fact that, in decolonisation situations at least, it is reinstating circumstances resembling those that existed before colonial invasion and

633 Knop, above n 176, at 72, citing Jorrie C Duursma Fragmentation and the International Relations of Micro-States: Self-Determination and Statehood (Cambridge University Press, Cambridge, 1996) at 78.

634 For example, see: Resolution 1514, above n 208; Resolution 1541, above n 424; Brownlie, above $n$ 335, 107-108; Cassese, above n 146, at 71-89; Crawford, above n 169, at 107-128; French, above n 232, generally; Raič, above n 148; Shaw, above n 91, at 149-150; and Thomas W Simon "Remedial Secession: What the Law Should Have Done, From Katanga to Kosovo" (2011) 40 Ga J Int'l \& Comp L 105.

635 Cassese, above n 146, at 333. 
domination. ${ }^{636}$ Regardless, here we are not concerned with a situation that involves the potential break-up of an existing State or a State losing its colonial territories in order to create a new State. Rather, the issue relates to the continuity of an extant State.

Self-determination is also relevant in maintaining existing states of affairs. In this regard, this collective right is harmonious with two other principles of international law that are also central to protecting the status quo. These are the prohibition of the threat or use of force, and the rule against intervening in States' internal affairs. ${ }^{637}$ On the former, the General Assembly has stated that "[e]very State has the duty to refrain from any forcible action that deprives peoples ... of their right to self-determination". ${ }^{638}$ The threat or use of force can affect both external and internal self-determination. For example, it might affect a State's international legal personality in cases of annexation, and it might affect the representativeness of the Government of the State where the invading power overruns legitimate representation. Indonesia's invasion and integration of East Timor in 1975-1976 is one example of such risks. ${ }^{639}$

With regards to the rule against interference, its link to self-determination was recognised by the UN General Assembly in 1965. It was concerned that "armed intervention and other direct and indirect forms of interference threatening the sovereign personality and the political independence of States" was affecting the General Assembly's aim of "respect for the principle of equal rights and self-determination. ${ }^{640}$ It thereby declared that "[a]ll States shall respect the right of self-determination and independence of peoples and nations, to be freely exercised without any foreign

RS Bhalla "The Right of Self-Determination in International Law" in William Twining (ed) Issues of Self-Determination (Aberdeen University Press, Aberdeen, 1991) 91 at 92.

637 Charter of the United Nations, art 2(4); Nicaragua, above n 439, at 106; Friendly Relations Declaration, above n 226, at 122-124; Resolution 2131, above n 247; Hurst Hannum "Self-Determination in the Post-Colonial Era" in Donald Clark and Robert Williamson (eds) Self-Determination: International Perspectives (Macmillan Press, Basingstoke, UK 1995) 12 at 25; Cassese, above n 146, at 334; Crawford, above n 169, at 128.

638 Friendly Relations Declaration, above n 226, at 124.

639 Ian Martin Self-Determination in East Timor: The United Nations, the Ballot, and International Intervention (Lynne Rienner Publishers, Boulder CO, 2001) at 16-17.

640 Resolution 2131, above $\mathrm{n} 247$, at preamble, first and second recitals. 
pressure". ${ }^{641}$ According to Crawford, the rule against intervening in internal affairs, particularly choices of governments, is not only harmonious with self-determination but actually represents that principle. ${ }^{642}$

All of these international law elements - the presumption of continuity, the right to self-determination, the rule against the threat or use of force, and the rule against interference - operate independently and in harmony with each other to protect the status quo of States. In particular, the interrelationships between self-determination and those other rules illustrate that self-determination prevents the international community from making decisions that threaten present enjoyment of this right. Cassese explains: ${ }^{643}$

\footnotetext{
... while before 1945 the various members of the international community could afford to take decisions without making allowance for the wishes of peoples and international dealings ultimately consisted of relations between potentates, since the adoption of the UN Charter self-determination has gradually acquired the status and force of a set of generally and legally binding guidelines for the actions of sovereign States.... [S]elf-determination means the freedom to choose one's own international status.
}

For the peoples of low-lying States, the right to self-determination means that their views about their extant external self-determination and statehood statuses take primacy over any attempts by the international community to make determinations on such matters. Conceptually, this is consistent with the fact that self-determination casts doubt or voids legal title over territory acquired, or sought to be acquired, through colonisation or annexation, and prevents the transfer of title without prior and proper consultation with the affected population. ${ }^{644}$

There can be little doubt that, in practice, self-determination has a material role in statehood questions, and can play a crucial, supporting role in statehood continuity in situations involving threats and use of violence or other interference in internal affairs.

\footnotetext{
641 At [6].

642 Crawford, above n 169 , at 128 .

643 Cassese, above n 146, at 323-324.

644 Cassese, above n 146, at 324.
} 
As Crawford states, "self-determination is, at the most basic level, a principle concerned with the right to be a State" and, therefore, the right applies to existing States as "a continuing, and not a once-for-all right". ${ }^{645}$ Similarly, the right of low-lying peoples to self-determination fortifies them against others' determinations regarding their States. Only they have the power in international law to determine the fate of this important international legal personality.

\section{The Relationship between the Presumption of Continuity and the Montevideo Indicia}

The low-lying States' statehood should also be presumed to continue despite relocation because of how the Montevideo indicia are applied to existing States. As will be discussed, the indicia were defined for creating new States, not for the potential termination of existing States. Therefore, there is so-far unlimited flexibility for existing States in terms of how or whether the indicia are satisfied. This dynamism further evidences the presumption of continuity: low-lying States do not need to satisfy the indicia to maintain statehood.

\section{A. New States Only; Not Termination}

As outlined earlier, some commentators have indicated that the failure of low-lying States to satisfy one or more Montevideo indicia could lead to termination of statehood. ${ }^{646}$ A plain reading of art 1 of the Convention may suggest this is feasible. It states that "[t]he state as a person of international law should possess the following qualifications", and then sets out the indicia. However, basing the low-lying States' continuity or termination on the Montevideo indicia is flawed. When it was adopted in 1933, a purpose of the Montevideo Convention was to liberalise and regulate how independence was gained, moving away from principles governing statehood that were intended to protect European

645 Crawford, above n 169, at 107 and 128; and see Chapter 2, Part IV(B)(2).

646 This Chapter, Part III. 
dynasties. ${ }^{647}$ This has led Grant to conclude that "the Montevideo Convention was concerned with whether an entity became a state, not with how an entity might cease to be a state." ${ }^{648}$ This is consistent with the limited records of the dialogue at the time. There is no evidence in those records that parties and signatories to the Montevideo Convention anticipated that the statehood criteria they codified for liberalising and regulating the gaining of independence might also be used to terminate States. ${ }^{649}$ Thus, it appears Grant was correct in finding that the Montevideo indicia are not legal thresholds applicable to extinguishing existing States' statehood. In fact, there are no rules on the termination of States in circumstances remotely analogous to those of the low-lying States. As discussed earlier, the rules which do exist about the end of States relate to unrelated circumstances of succession in decolonisation, the dividing up of States, secession, and merger. 650

\section{B. Permanent Population}

The conclusion that the Montevideo indicia are not legal thresholds for potential statehood termination is also evidenced by exceptions to their satisfaction by current States and the so-far unlimited flexibility in how they are satisfied. There are examples for all four indicia.

Regarding the permanent population, it is well accepted that there is no minimum number. ${ }^{651}$ More than that, to be "permanent", a population only needs to be maintained by administrative measures. The Vatican City State's population of just 800 citizens and

647 Grant, above n 611, at 418-419. See also William Manger "The Seventh International Conference of American States" (1934) 4 Bulletin of the Pan American Union 271 at 274 and 275; LS Rowe "The Significance of the Seventh International Conference of American States" (1934) 28 Proceedings of the American Society for International Law at its Annual Meeting (1921-1969) 34 at 35-36; and James Brown Scott "The Seventh Conference of American States" (1934) 28(2) The AJIL 219 at 226.

648 Grant, above n 611, at 435; and see also Lilian Yamamoto and Miguel Esteban Atoll Island States and International Law: Climate Change Displacement and Sovereignty (Springer, Heidelberg, 2014), at 182.

649 See Manger, above n 647, at 274-275; Rowe, above n 647, at 35-36; and Scott, above n 647, at 226.

650 This Chapter, Part IV.

651 In re Duchy of Sealand (Administrative Court of Cologne, Germany) [1978] 80 ILR (1989) 683 at 687; and see Crawford, above n 169, at 52. 
residents $^{652}$ is "transient, comprising the main papal officials and employees, who are allowed to reside." ${ }^{653}$ As Robertson explains, "no Vaticanian is ever born, other than by accident ... [so the Vatican population] is not 'permanent' in the sense that it can be self-perpetuated or entitled to remain for generations." ${ }^{654}$ There are debates about whether the Vatican is a State, ${ }^{655}$ even though the UN has classified it as a Non-Member State with Permanent Observer status since 1964, ${ }^{656}$ it "enjoys the rights and incurs the responsibilities of a state", ${ }^{657}$ and it asserts as much on its official website. ${ }^{658}$ Regardless, the importance of this case is that the Vatican's statehood is not automatically terminated by virtue of the fact that its diminutive population persists purely through administrative apparatus. For such reasons, multiple authors have looked towards the Vatican as offering insights for ex situ statehood. ${ }^{659}$

The case of the Vatican illustrates how flexibly the permanent population indicia can be met, having only a tiny population that is maintained purely through administrative arrangements. Stoutenburg discusses the possibility of the population indicia being maintained by low-lying States by having a small "population nucleus [that] serve[s] as legal anchor to the probably much larger diaspora of island people". ${ }^{660}$ This nucleus could be very small. The General Assembly has recognised the right of the Pitcairn Islands to "self-determination and independence" when it has a population of around 50 people. ${ }^{661}$

652 Vatican City State "Population" <www.vaticanstate.va>.

653 Morss, above n 576, at 931.

654 Geoffrey Robertson The Case of the Pope: Vatican Accountability for Human Rights Abuse (Penguin Books, London, 2010) at [116].

655 For example, see Yasmin Abdullah "The Holy See at United Nations Conferences: State or Church" (1996) 96(7) Colum.L.Rev. 1835; Crawford, above n 169, at 221-233; Duursma, above n 633, at 374419; Morss, above n 576; and Robertson, above n 654, at [113]-[137].

656 UN "Non-Member States" <www.un.org>; and Kurt Martens "The Position of the Holy See and Vatican City State in International Relations" 83 U.Det.Mercy L.Rev 729 at 758.

657 Ioana Cismas Religious Actors in International Law (Oxford University Press, Oxford, 2014) at 155 and 171 .

658 Vatican City State "State and Government" <www.vaticanstate.va>.

659 Burkett, above n 105, at 356-357; McAdam, above n 41, at 158-159; Rayfuse, above n 101, at 10; Stoutenburg, above n 127, at 66; and Yamamoto and Esteban, above n 648, at 204-206.

660 Stoutenburg, above n 127 , at 65.

661 At 63-64, citing Question of American Samoa, Bahamas, Bermuda, British Virgin Islands, Brunei, Cavman Islands, Cocos (Kealing) Islands, Gilbert and Ellice Islands, Guam, Montserrat, New 
Stoutenburg argues that this nucleus would need to be based on a low-lying State's original territory otherwise statehood could be preserved only "in the sense of a legal fiction". ${ }^{62}$ However, this population nucleus could be established in an ex situ arrangement without it being a mere legal fiction. Chapter 5 examines options for establishing an ex situ population nucleus, which in turn supports ex situ self-determination including statehood.

\section{Defined Territory}

Another illustration of the Montevideo indicia's flexibility is how territory is applied: territory does not need to be habitable. Uninhabitable and uninhabited territories can be part of the overall territory of a State. There are many such examples. Kiribati's territory includes nine uninhabited atolls. ${ }^{663}$ Australia's territory includes 147 uninhabited islands. ${ }^{664}$ New Zealand's territory includes the uninhabitable Bounty and Snares Islands. ${ }^{665}$ And there numerous other examples around the globe. ${ }^{666}$ Of course, those uninhabitable territories belong to States that have habitable territory, otherwise the low-lying States' situations would not be unprecedented. However, these examples demonstrate that uninhabitable territory does qualify as territory. Low-lying States' statehood could be measured against their original, albeit uninhabitable atoll territories, among other things. Furthermore, there are multiple options for land in the partner State, including holding it as territory or property, and acquiring through cession, shared condominium, purchase or lease. ${ }^{667}$

Hebrides, Pitcairn, St. Helena, Seychelles, Solomon Islands, Turks and Caicos Islands and the United States Virgin Islands GA Res 2869 (XXVI) (1971) at [2].

662 At 66.

663 National Statistics Office, above n 182, at 31; and Wikipedia "List of Islands of Kiribati" <www.wikipedia.org>.

664 For a full list of Australia's 147 uninhabited islands, see Wikipedia "Uninhabited islands of Australia" <www.wikipedia.org>.

665 Joanna Mossop "The South China Sea Arbitration and New Zealand's Maritime Claims" (2017) 15 NZJPIL 265 at 279-280.

666 See Wikipedia "Desert Island" <www.wikipedia.org>.

667 Chapter 5, Part III. 
As an aside, some commentators have looked to the definition of an island in the UN Convention on the Law of the Sea (UNCLOS) ${ }^{668}$ to determine what land comprises territory for the purposes of statehood. ${ }^{669}$ They have done so because there is no useful definition of what comprises territory, except in unrelated circumstances. ${ }^{670}$ However, relying on UNCLOS for statehood purposes is problematic. Article 121(1) of UNCLOS defines an "island" as "a naturally formed area of land, surrounded by water, which is above water at high tide". Article 121(3) adds that "[r]ocks which cannot sustain human habitation or economic life of their own shall have no exclusive economic zone or continental shelf." ${ }^{671}$ The argument relating to low-lying States' statehood has been that what qualifies as an island according to UNCLOS is equally territory for the purposes of considering statehood continuity. However, art 121 does not provide a definition of territory; only a definition of islands and other high-tide features for the purposes of determining which maritime zones apply. Research conducted for this thesis has been unable to locate any decisions about statehood that have even referred to UNCLOS, let alone rely on it to address territory questions. Presumably, this is because the definition of an island in UNCLOS is not provided for the purpose of assessing continuity of statehood. The purposes of UNCLOS are to settle issues relating to the law of the sea, address problems of ocean space, and promote peaceful uses of the seas and oceans. ${ }^{672}$ Statehood falls outside those purposes.

Relating to this, "the land is the legal source of power which a State may exercise over territorial extensions to seaward". ${ }^{673}$ So, although "[t]he sovereignty of a coastal$$
\begin{aligned}
& \text { In the South China Sea Arbitration, art 121(3) has been interpreted to apply, not only to geological } \\
& \text { features that are solid rock, but also to other natural features, such as coral reefs. For that reason, the } \\
& \text { tribunal used "high-tide features" as alternative nomenclature to "islands": South China Sea } \\
& \text { Arbitration, above n 595, at [280] and [479]-[482]. }
\end{aligned}
$$

672 UNCLOS, at preamble, first, third and fourth recitals.

673 North Sea Continental Shelf Cases (Germany v Denmark; Germany v Netherlands) (Judgment) [1969] ICJ Rep 3 at 51; and see UNCLOS, art 5. For a historical background to this principle, see Lea Brilmayer and Natalie Klein "Land and Sea: Two Sovereignty Regimes in Search for a Common Denominator" (2001) 33 NYU J.Int'l Law \& Pol. 703 at 717.

For example, Jain, above n 105, at 35; Stoutenburg, above n 127, at 60-63.

For example, Island of Palmas case (The Netherlands v USA) (Award) PCA 23 January 1928, (1928) 2 RIAA 829 at 838 and 855.$$
\text { Denominator" (2001) } 33 \text { NYU J.Int'l Law \& Pol. } 703 \text { at } 717 .
$$ 
State extends, beyond its land territory ... to an adjacent sea", ${ }^{674}$ it is erroneous to use maritime zones to support claims of land territory. Attempting to do so requires inverting the direction of the flow of authority. Thus, while the UNCLOS definition of an island may be somewhat useful as a kind of "state of the environment" indicator, it offers no assistance to the legal question of what comprises a low-lying State's territory for the purposes of statehood. In other words, it does not provide a legal milestone which, if reached, would result in statehood being terminated.

\section{Government}

The third Montevideo indicia of statehood, government, demonstrates perhaps the greatest flexibility for extant States. This is critical since, according to Crawford, "[t]here is ... a good case for regarding government as the most important single criterion of statehood, since all the others depend upon on it." 675 What, then, is "government"? Political science defines it openly as a group of people, and a set of systems and processes, which, combined, have pervasive authority to influence, organise and control a particular people through law, coercion and other means. ${ }^{676} \mathrm{With}$ the various forms it takes - monarchies, republics and theocracies, as well as democracies, totalitarian governments and dictatorships, all of which are organised and function in various different ways - it is unsurprising that the form of government is irrelevant for statehood purposes. The ICJ said in Western Sahara that: ${ }^{677}$

No rule of international law, in the view of the Court, requires the structure of a State to follow any particular pattern, as is evident from the diversity of the forms of State found in the world today.

Add to this Crawford's conclusion that: ${ }^{678}$

674 UNCLOS, art 2(1).

675 Crawford, above n 169, at 56.

676 Roger Scruton A Dictionary of Political Thought (Pan Books, London, 1983) at 189; and W Phillips Shively Power \& Choice: An Introduction to Political Science (Rowman \& Littlefield, Lanham, Maryland, US, 2019) at 13.

677 Western Sahara, above n 255, at 43-44.

678 Crawford, above n 169, at 59. 
... international law lays down no specific requirements as to the nature and extent of this [governmental] control [of territory], except that it include some degree of maintenance of law and order and the establishment of basic institutions.

Thus, there is potentially unlimited flexibility for how this indicia may be satisfied.

This flexibility is illustrated by two configurations: fragile States and governmentsin-exile. These diminished governments endure extreme pressures and reduced capabilities, which is comparable to what the low-lying States may experience.

Fragile States (previously known as 'failed States') are those where governments have collapsed or suffer extremely limited capabilities for providing State functions. ${ }^{679}$ This is not a legal definition, but rather a general definition that helps assess situations and determine how to respond to various and complex forms of fragility. ${ }^{680}$

The case of Somalia is informative. Somalia was categorised as a fragile State following the collapse of government structures in 1991, which led to widespread, prolonged anarchy and lawlessness. ${ }^{681}$ It remains a fragile State today. ${ }^{682}$ Despite its prolonged period without effective government, Somalia's statehood continues, as does its membership in the UN, the World Bank, and the African Union. ${ }^{683}$ Somalia also maintains international relations with other states. For instance, the United States closed its Mogadishu Embassy in 1991 but re-established a permanent diplomatic presence in 2018) at 28-37; OECD States of Fragility 2018 (OECD Publishing, Paris, 2018) at 22-27; and OECD States of Fragility 2016: Understanding Violence (OECD Publishing, Paris, 2016) at 21; and John Yoo Point of Attack: Preventative War, International Law, and Global Warfare (Oxford University Press, Oxford, 2014) at 161-162. Action" (High-Level Meeting on Somalia, United Nations, New York, 24 September 2016); and UNSC "Somalia has not been abandoned by international community, say speakers in Security Council" (press release, SC/6194, 15 March 1996 (statements of the Representatives of the Republic of Korea and Botswana).

682 Messner and others, above $\mathrm{n} 679$, at 7 and 9.

683 United Nations, above n 560; World Bank "Member Countries" <www.worldbank.org>; and African Union "Member State Profiles" <www.au.int>. 
2018, and in the period between, the US was involved in dispute resolution efforts. ${ }^{64}$ Somalia also remains subject to the international order. For example, while "[r]eaffirming its respect for the sovereignty, territorial integrity, political independence and unity of Somalia", the UNSC continues to impose sanctions. ${ }^{655}$ Overall, the case of Somalia illustrates that the presumption of continuity persists for, in this case, 28 years irrespective of its being unable to satisfy the government indicator of statehood.

Governments-in-exile, by comparison, show that government can be established outside the State's territorial jurisdiction with a partner State's consent. This configuration: ${ }^{686}$

... does not denote special legal status or an independent subject of international law, but indicates the domicile of a government, i.e. the depository of a State's sovereignty and its representative organ in international relations.

Recognised governments-in-exile "have the right to exercise governmental functions and to enjoy governmental privileges and immunities within the jurisdiction of the recognizing state." ${ }^{687}$ As Burkett explains, "[g]overnments in exile are examples of functioning, yet non-territorial, sovereignty that international law recognizes." 688

Neither of these diminished governments - fragile States and governments-in-exile - are directly analogous to the low-lying States' scenarios. A question, therefore, is whether they offer any guidance as to low-lying States' potential satisfaction of the government indicia and, if so, what guidance. There are three limits to the analogy, but it is submitted here that the core elements of international practice support recognition of low-lying States' ex situ, and possibly diminished governments.

US Mission to Somalia "Arrival of U.S. Ambassador to Somalia Donald Y. Yamamoto" (press release, 15 November 2018); and Department of State "U.S. Relations With Somalia" (US) <www.state.gov>. Resolution 2444 SC Res 2444, SC/Res/2444 (2018) at preamble, third recital, and [13], [41] and [50]. Stefan Talmon Recognition of Governments in International Law: With Particular Reference to Governments in Exile (Oxford University Press, Oxford, 1998) at 16 (citations omitted).

At 269.

Burkett, above n 105, at 357 
The first limit with the analogy is that fragile States and governments-in-exile situations are anticipated to be temporary. ${ }^{689}$ Low-lying States may go into a permanent state of disorder, in which case the comparison may be moot, but any disorder suffered may be temporary. For example, perhaps there may be a tumultuous period while rival groups dispute which one of them legitimately represents the people in ex situ arrangements that are eventually established. Such disputes are hardly uncommon, with Venezuela and Yemen being contemporary examples. ${ }^{690}$

Compared to governments-in-exile, low-lying States' exiles will be permanent. As an unprecedented situation, it is unclear whether low-lying States would be excluded from benefiting from arrangements akin to those which sustain governments-in-exile because of this differentiation. It seems likely, however, that an important factor will be the recognition of the low-lying peoples and States in any legal frameworks regarding the relocation enterprise. ${ }^{691}$ The other critical legal factors are, as discussed, the presumption of continuity, their right to self-determination, and their exclusive competence to decide whether to alter or terminate their extant statehood statuses.

The second limitation in comparing diminished States' continuity with low-lying States is that governments-in-exile are expected to go or return to a particular territory, and fragile States exist relative to a known territory. These diminished States "depend on the existence of a definable territory as a foundation of their legitimacy." ${ }^{692}$ For low-lying States with only uninhabitable territories, this will be impossible. However, the government may exist without habitable territory as a nation ex situ, whereby "[t]he government ... would sit in a permanent location and manage the affairs of the state at a

McAdam, above n 41, at 135; and Rosemary Rayfuse and Emily Crawford "Climate Change, Sovereignty and Statehood" (Sydney Law School, Legal Studies Research Paper No. 11/59, September 2011), at 8.

690 Regarding Venezuela, see Max Fisher "Who is Venezuela's Legitimate President? A Messy Dispute, Explained" (4 February 2019) New York Times <www.nytimes.com>. Regarding Yemen, see: BBC "Yemen Crisis: Why is There a War?" (18 December 2018) <www.bbc.com>; Angus McDowall "Why Yemen is at war" (16 June 2018) Reuters <www.reuters.com>; Al Jazeera "Key facts about the war in Yemen" (26 March 2018) <www.aljazeera.com>.

691 See Chapter 5, Part IV.

692 Celia A Taylor "The Modest Proposal: Statehood and Sovereignty in a Global Age" (1997) 18(3) U.Pa.J.Int'l Econ. L 745 at 758. 
distance." 693 The low-lying State may exist ex situ and exercise sovereignty over its uninhabitable territories, or have new territory obtained from, or shared with, a partner State, or some combination thereof. Options regarding land are discussed in chapter 5.

The third distinction in these analogies are the facts leading to the various situations. Many governments-in-exile and fragile States cases involve military occupation, attempted annexation, internal violence, and grave human rights violations, although some also involve steps in decolonisation. ${ }^{694}$ Some of these situations also involve breaches of peremptory norms, such as the prohibition of aggression and genocide. While climate change and climate migration involve widespread impacts on human rights, these are more akin to humanitarian crises that trigger emergency relief efforts. However, other aspects of the low-lying States' situations are comparable to certain diminished States' circumstances: those in decolonisation efforts are about enabling self-determination, which is challenged in the low-lying States' relocation enterprises.

Whilst these weaknesses to the analogies must be acknowledged, it is submitted that fragile States and governments-in-exile illustrate practice and demonstrate lessons that can be translated to the low-lying States, particularly: the retention of governments ex situ and the retention of statehood without government; and the potential to limit governmental jurisdiction and capacity to support continuity of government without offending the rights of destination States. These lessons will be discussed in turn.

First, in terms of the government indicia and statehood continuity, diminished States show that statehood can be, and is already retained without governments that function as they do in, what might be described loosely as, majority situations. Governments-in-exile demonstrate that separation from territory does not fatally undermine the government indicia nor statehood. ${ }^{695}$ Fragile States demonstrate that, even where the government indicia is not satisfied, "there is a strong presumption against the

693

Messner and others, above n 679, at 35; Talmon, above n 686, at 96-97 and 102; and Yoo, above $n$ 679 , at 159.

695 McAdam, above n 41, at 135. 
extinction of States once firmly established", ${ }^{696}$ as discussed. If low-lying States' governments fall into disorder, international practice regarding diminished States demonstrates a significant grace period. That is, if a low-lying State cannot secure new, ex situ arrangements in advance, then a degree of stability for the international legal person should remain feasible during very prolonged periods of disorder while those arrangements are established. ${ }^{697}$ Such grace periods can last decades. The Baltic States, for example, re-established themselves after more than 50 years of Soviet occupation that involved domination of government. ${ }^{698}$ Securing arrangements in advance will no doubt be preferable, as that will allow governments to research, deliberate and consult on options for how ex situ government and governing may be modelled and conducted. Failing that, practice with other diminished States provides low-lying States a period to develop and negotiate ex situ arrangements at least as long as that which Somalia and the Baltic States endured.

The second lesson from diminished States is that, because of their circumstances, the scope of their capacities has been limited but they continue nonetheless. On the international stage, fragile States maintain international relations, maintain membership to international and regional organisations, remain subject to international law, and enjoy recognition of sovereignty and political independence. Governments-in-exile can also legitimately adopt treaties and maintain diplomatic relations. ${ }^{699}$ These are useful guides for low-lying States re-establishing themselves ex situ. However, in terms of their domestic jurisdictions, the scope of their capacities may be far more limited than the case in diminished States' situations. This has been the case for governments-in-exile, where the host State has complete or very extensive domestic jurisdiction, while the exiled

Crawford, above n 169, at 715 .

At 132.

698 Soonchun Lee "Identity and Continuity of State: The Cases of the Baltic States and Korea" (2011) 10 Korean University Law Review 149 at 152; and Ziemele, above n 382, at 27-28, and see generally $18-31$.

699 Rayfuse and Crawford, above n 689, at 8; and see Crawford, above n 169, at 688. 
government focuses on enabling its own return. ${ }^{700}$ For this reason, Park and McAdam foresee the partner States' jurisdictions dominating the low-lying States'. ${ }^{701}$

However, it is submitted that it is a matter which is open to exploration. States accommodate, to varying degrees and with varying degrees of success, multiple normative systems as a matter of course. For instance, legal systems commonly afford special privileges for religions and their norms, ${ }^{702}$ and there can be an ongoing negotiation of jurisdictional space between indigenous peoples and national governments. ${ }^{703}$ In commerce, there are interactions between law and industry practices and codes of conduct. ${ }^{704}$ Even within countries, jurisdictions are divided between, or delegated amongst, national, provincial, and local governments. It is not within scope to explore these and consider which, if any, offer useful lessons for low-lying and partner States. However, these cases of having more than one normative system within States illustrate the theoretical potential for low-lying States to enjoy capacities beyond those that have sufficed for governments-in-exile.

In terms of how the international community supports diminished States, practice is inconsistent. ${ }^{705}$ It includes the absence of intervention, military intervention, providing support for basic political and economic stability, and seeking to restore governmental institutions. ${ }^{706}$ Support may also include the ongoing recognition of governments through,

700 For a case study, Jose outlines the functions of the Philippines' government-in-exile in the United States during Japanese occupation in World War II: Ricardo T Jose "Governments in Exile" 8(1-2) Asian and Pacific Migration Journal 179 at 183-186.

701 See Park, above n 28, at 7; and McAdam, above n 101, at 135-138.

702 See generally Rubya Mehdi "Law versus Religion: State Law and Religious Norms" in Jan Klabbers and Touko Piiparinen Normative Pluralism and International Law: Exploring Global Governance (Cambridge University Press, Cambridge, 2013) 284.

703 Matthew SR Palmer The Treaty of Waitangi in New Zealand's Law and Constitution (Victoria University Press, Wellington, 2008) at 291-293 and generally.

704 See generally Katja Creutz "Law versus Codes of Conduct: Between Convergence and Conflict" in Klabbers and Piiparinen, above n 702, 166; and Ulla Liukkunen "Lex Mercatoria in International Arbitration" in Klabbers and Piiparinen, above n 702, 201.

705 Yoo, above n 679, at 168.

706 At 168-169. 
for example, ongoing diplomatic relations or expressions of opinion by third-party States on the legal status. ${ }^{707}$

In the low-lying States' scenarios, however, the issue of international support relates to States; not just governments. As such, there is a requirement to refrain from withdrawing recognition of statehood. ${ }^{708}$ International support also relates to peoples and their right to self-determination. If a low-lying people, through their State, express a wish to maintain statehood and government ex situ, this would be an act of self-determination. As such, Parties to the 1966 Covenants are obliged to "promote the realization of the right of self-determination" and to "respect that right". ${ }^{709}$ Indeed, Thürer finds that, when the international community intervenes in such situations, via the UN, it does so based on "the invocation of human rights and the right to self-determination". ${ }^{710}$ This fact supports the conclusion reached earlier in this thesis that self-determination is relevant, not only to the creation of new States, but also to the continuity of States. ${ }^{711}$ Moore takes this further, suggesting that self-determination may create "a duty of hospitality" towards low-lying States' governments-in-exile. ${ }^{712}$ Additionally, if government is lost, then the right to self-determination "provides the basis upon which to establish a new one". ${ }^{713}$

Overall, governments-in-exile show that the international community is capable of recognising a government situated outside its original territory, and fragile States show it is capable of recognising an extant State without government. There are certain dissimilarities in the analogies between failed States, governments-in-exile and the Cross 731 (available at <www.icrc.org>). Self-determination was also cited by the Parliamentary Assembly of the Council of Europe in its deliberations regarding the Baltic States, stating "the incorporation of the three Baltic states into the Soviet Union was and still is a flagrant violation of the right to self-determination of peoples": Parliamentary Assembly of the Council of Europe Situation of the Baltic peoples PACE Res 872 (1987) at [3].

711 Chapter 3, Part IV(B)(2).

712 Cameron Moore "Waterworld: Climate change, Statehood and the right to self-determination" in Quirico and Boumghar, above n 513, 104 at 112 (citations omitted).

713 At 113. 
low-lying States' scenarios. And, depending on the severity of their circumstances, diminished States might only be States "on paper". ${ }^{714}$ Nonetheless, these flexible arrangements provide an important interim or permanent solution, not only for the affected State, but also for the international order. As Thürer observes: ${ }^{715}$

\footnotetext{
... from the point of view of international law, ... the States concerned are, in practice, not simply left to their fate. On the contrary, the collapse of a State anywhere in the world is seen as a matter for the international community, since the international system as a whole is felt to be endangered if one of its members is seen to be no longer functioning.
}

The expansive flexibility of this indicia - in terms of whether, how and where it is satisfied - suggests that statehood is not terminated due to a loss of, or major changes to government. Low-lying States can make governments work ex situ, particularly if they can secure suitable arrangements with their partner States. The fact that low-lying States can opt out of a significant degree of capacity should help allay the concerns of partner States, and they might refer to other models of normative pluralism to dovetail their respective systems. However it is organised, satisfaction of the government indicator is not ended by virtue of relocation alone, and the failure to satisfy this indicia does not terminate statehood.

\section{E. Capacity to Enter International Relations}

Statehood can continue despite extended periods without governmental capacity to fulfil basic functions, including gaps in, or limited fulfilment of, capacities for conducting international relations. According to the American Law Institute (ALI), in its Restatement of the Law, Third, Foreign Relations Law of the United States (Third Restatement of the Law), the Montevideo indicia of capacity to enter into international relations involves both legal and administrative capacities: ${ }^{716}$

714 Nii Lante Wallace-Bruce "Of Collapsed, Dysfunctional and Disoriented States: Challenges to International Law" (2000) 47 NILR 53 at 61.

715 Thürer, above n 710. See also Jain, above n 105, at 10-11; and Yoo, above n 679, at 159.

716 American Law Institute U.S. Restatement of the Law, Third, Foreign Relations Law of the United States, Vol. 1 [Third Restatement of the Law], § 201; and see Stoutenburg, above n 127, at 70. 
An entity is not a state unless it has competence, within its own constitutional system, to conduct international relations with other states, as well as the political, technical and financial capabilities to do so.

Irrespective of whether this is an accurate representation of what is required to gain statehood, there are, yet again, exceptions for existing States. Statehood can continue without legal or administrative capacities for international relations, and where a State devolves responsibilities for international relations to another State.

Fragile States demonstrate that continuity persists even where constitutional institutions that provide for legal capacity for conducting international relations are suspended. ${ }^{717}$ Therefore, a lengthy grace period is available to low-lying States to establish legal capacity, should it lose such capacity temporarily during a relocation enterprise. That grace period can last for decades, as the cases of governments-in-exile and fragile States illustrate.

On the administrative aspects, there is no minimum threshold against which to assess an entity's "political, technical and financial capabilities"718 to conduct international relations. The low-lying States' current administrative capacities are limited. For instance, the author met officials from Tuvalu's Ministry of Foreign Affairs and found it has just a handful of staff; perhaps six or seven personnel. By contrast, Australia's Department of Foreign Affairs and Trade has over 6,000 staff, ${ }^{719}$ and the United States' Department of State has over 75,000 employees. ${ }^{720}$ It would appear, therefore, that some administrative resource is all that low-lying States would need to maintain following relocation.

Low-lying States can also devolve responsibility for international relations to a partner State in a bilateral arrangement regarding relocation without losing satisfaction of

\footnotetext{
717 Messner and others, above n 679, at 35.

718 Third Restatement of the Law, above n 716, § 201; and see Stoutenburg, above n 127, at 70.

719 Department of Foreign Affairs and Trade (AU) "Annual Report 2017-18" at ii.

720 Department of State (US) "HR Fact Sheet: Facts About Our Most Valuable Asset - Our People: As at $12 / 31 / 2018$.
} 
this Montevideo indicia. The potential for such devolution is recognised in the Third Restatement of the Law, ${ }^{721}$ and Liechtenstein provides a contemporary example. Liechtenstein's legal capacity for international relations is provided for in its constitution. $^{722}$ While it engages in international affairs, especially its bilateral relationships with neighbouring States and its participation in the European Economic Area, ${ }^{723}$ some of Liechtenstein's foreign relations are conducted on its behalf by Switzerland. ${ }^{724}$ This illustrates that, in terms of legal capacity, a low-lying State could devolve some aspects of its international relations to its partner State and still satisfy this indicia.

Overall, low-lying States can suffer extended periods without legal or administrative capacities to enter into international relations, but this does not indicate a general loss of capacity to continue international relations. They can also fulfil this indicator with minimal financial and administrative capacities, and have the option of outsourcing competence to the partner State. Nevertheless, it would be valuable to recognise their legal capacity in agreements establishing their ex situ arrangements.

\section{F. The Potential Role of Self-Determination in Bolstering Continuity where there is only Partial Satisfaction of the Montevideo Indicia}

The examples in the preceding sections illustrate the relationship between the Montevideo indicia and the presumption of continuity, showing the presumption in effect despite one or more indicia not being satisfied. The interrelationship of laws may extend to include self-determination. This section introduces a hypothesis: that the presumption of continuity persists where there are gaps in satisfying Montevideo indicia because of the right to self-determination.

\footnotetext{
721 Third Restatement of the Law, above n 716, § 201.

722 Constitution of the Principality of Liechtenstein 2003, art 67(2).

723 Ministry of Foreign Affairs (LI) Priorities of Liechtenstein Foreign Affairs (Government of the Principality of Liechtenstein, Vaduz) at 13-17.

724 Duursma, above n 633, at 201; and see Crawford, above n 169, at 70.
} 
Raič has proposed that, in the creation of new States, there is a "compensatory force principle". ${ }^{725}$ According to this principle, the right of external self-determination compensates for the lack of full satisfaction of statehood indicia and thereby enables entities to become States. Raič examined the emergence of four States - Bangladesh, Croatia, Georgia and Moldova - and found in all of them that one or more of the Montevideo indicia were only partially satisfied: in their putative conditions, they lacked effective governments and could not assert complete authority over their territories. ${ }^{726}$ Nevertheless, they were recognised as States, not as exceptions to the rule, but in accordance with the right to self-determination. This is the basis for Raič's proposal that a "compensatory force principle" has emerged, which hinges upon self-determination permitting "juridical statehood" in the absence of complete "empirical statehood", ${ }^{727}$ the former being akin to the principle of legality and the latter akin to the principle of effectiveness. This differs from Stoutenburg's analysis regarding continuity questions. She concluded that the principle of legality takes precedence over effectiveness only where there is a breach of a jus cogens norm, ${ }^{728}$ but no such breach exists in Raič's case studies.

According to Klabbers, Raič's thesis does not address sufficiently the roles of politics and recognition in the creation of States. However, Klabbers finds the compensatory force principle plausible since effectiveness does not explain all situations and external self-determination does influence recognition policies. ${ }^{729}$

It is not the purpose here to attempt to resolve the question, but to pose the question for future research: if the compensatory force principle does exist in the creation of new States, what might it contribute to analysing the presumption of continuity? If extant States which suffer empirical losses can benefit from this principle, then it is another

725 Raič, above n 148, at 409.

726 Crawford, above n 169, at 56-57; Raič, above n 148, at 406 and 441; and Stoutenburg, above n 127 , at 67.

727 Raič, above n 148, at 409 and 437.

728 Stoutenburg, above n 127, at 59 and 74-75; discussed above in Part III of this Chapter.

729 Jan Klabbers "Book Review: D. Raič Statehood and the Law of Self-Determination" (2004) 10 International Journal on Minority and Group Rights 163 at 164. 
support for statehood continuity; that is, self-determination might compensate for any failure to satisfy all the indicia for establishing States. This thesis has already demonstrated that self-determination bolsters the presumption of continuity, which implies that it also functions in compensating extant States for any failure to satisfy the Montevideo indicia.

\section{G. Concluding on the Statehood Indicia}

Ceasing to satisfy a Montevideo indicia is not an automatic legal trigger for terminating statehood. As legal milestones, the indicia relate only to States' creation, not extinction. This is evidenced by, inter alia, the so-far unlimited degree of flexibility of all the indicia for extant States, which has had the effect of preventing State extinctions. The extinctions which have occurred have only done so in circumstances that are not remotely analogous to the low-lying States' scenarios.

Any usefulness of the Montevideo indicia for low-lying States resides in how they offer factual benchmarks against which to assess the low-lying States' possible futures and to devise policy solutions to enable continuity if that is desired. There are ways of satisfying all the indicia in ex situ arrangements. Satisfaction will be unorthodox and perhaps very slight, but this is consistent with the very high degree of flexibility for extant States. Chapter 5 looks at ex situ options regarding legal personality and land, which have implications for all four indicia. Thus, despite some commentators' suggestions that statehood will be lost, there is real potential for formal and empirical satisfaction of these traditional indicia.

\section{Recognition by Third-party States}

Another issue for statehood is the role of recognition in low-lying States' continuity. Importantly, this is a very different legal question than the typical questions about the effect that recognition might have in the creation of new States. It is argued here that recognition is not relevant in terms of its legal effect on low-lying States' continuity, but 
positive acts to this effect would help resolve low-lying islanders' uncertainties and provide ongoing security in practical and political matters.

In the emergence of new States, the precise effect of recognition by third-party States is a matter of debate. ${ }^{730}$ The constitutive theory posits that statehood is created by recognition by other States, as the actors with such competence in the international legal system. The declaratory theory says statehood is attained and a new State comes into being as a consequence of its own endeavours and by satisfying the qualifications of the Montevideo Convention, so the effects of recognition are only practical and political. In another iteration, Lauterpacht's duty theory proposes that recognition should be required once an entity fulfils the statehood requirements. ${ }^{731}$

Arguably, this debate is irrelevant to the low-lying States. Their statehood is universally accepted and beyond question today. ${ }^{732}$ And, in Crawford's analysis, "[i]n many instances, the claim to continuity made by the State concerned will be determinative; other States will be content to defer to the position taken." 733 This raises the question, why might other States go against a low-lying State's position and withdraw recognition; what might they believe they could gain? Any such move will almost certainly relate to resources in maritime zones that will become part of the high seas. There might also be an objection in principle to a small entity with no territory exercising a vote in multilateral fora. However, the expected benefits would have to be weighed against the costs of disputes over claims to the supposed rights void if the low-lying State "disappeared". ${ }^{734}$ But, more important than speculating about such possibilities, the

730 See generally Ian Brownlie "Recognition in Theory and Practice" (1982) 53(1) BYBIL 197; Crawford, above n 169, at 17-28; Higgins, above n 128, at 43-44; Sean D Murphy "Democratic Legitimacy and the Recognition of States and Governments" (1999) 48(3) The International and Comparative Law Quarterly 545; and Shaw, above n 91, at 323-328.

731 See generally Hersch Lauterpacht, Recognition in International Law (Cambridge University Press, 1948) at 1. Consider also the discussion of the European Court of Human Rights on the subject in Loizidou v Turkey, above n 234, especially [45].

732 This Chapter, Part I.

733 Crawford, above n 169, at 668.

734 See Part IV of this Chapter. 
question in international law is whether third-party States have a right to withdraw recognition at all.

It is argued here that, even if a low-lying State is forced to relocate because of the effects of climate change, the only entity competent in international law to determine whether it maintains its statehood status is that low-lying State itself. ${ }^{735}$ Therefore, if or when they decide to maintain their statehood, the question is resolved. Although there will be many practical matters to be resolved, this conclusion is a logical consequence of key findings reached earlier in this chapter. To recap, these were that the low-lying States ought to enjoy the presumption of continuity of statehood, and this is bolstered by their right to self-determination and their exclusive competence to determine their political statuses. The presumption is reinforced further by the fact that the Montevideo indicia are not legal thresholds for potential statehood termination.

The finding that only low-lying States are competent to determine their statehood arises also because non-recognition of low-lying States due to their climate changeinduced relocation is not the same issue as non-recognition of a putative State. Any third-party State that does not wish to recognise an ex situ low-lying State will be required to withdraw their current recognition of accepted statehood statuses and sever any diplomatic relations. ${ }^{736}$ However, there is no authority or practice that suggests that withdrawal of recognition of an existing State would affect its statehood. In fact, the Montevideo Convention states that "[r]ecognition is unconditional and irrevocable." 737 Moreover, even non-recognition - as opposed to withdrawal of recognition - does not automatically have a legal effect on other matters, such as membership in international organisations. Turkey, for example, does not recognise Cyprus, and nor does North Korea recognise South Korea, but those latter States still enjoy UN Membership. ${ }^{738}$

\footnotetext{
735 This Chapter, Part V.

736 Yamamoto and Esteban, above n 648, at 183.

737 Montevideo Convention, art 6.

738 Yamamoto and Esteban, above n 648, at 183.
} 
As well as having doubtful legal effect, withdrawing recognition might constitute a breach of "the duty not to intervene in matters within the domestic jurisdiction of any State" contained in the Friendly Relations Declaration. ${ }^{739}$ In its Declaration on the Inadmissibility of Intervention in the Domestic Affairs of States and the Protection of their Independence and Sovereignty, the UN General Assembly stated that: 740

[1] No State or group of States has the right to intervene, directly or indirectly, for any reason whatever, in the internal or external affairs of any other State. Consequently, armed intervention and all other forms of interference or attempted threats against the personality of the State or against its political, economic and cultural elements, are condemned.

[2] No State may use or encourage the use of economic, political or any other type of measures to coerce another State in order to obtain from it the subordination of the exercise of its sovereign rights and to secure from it advantages of any kind.

Also relevant to this is the ${ }^{741}$

... inalienable sovereign right of every State to determine freely and without any form of foreign interference, its political, social and economic systems and its relations with other States and international organizations.

There are exceptions to the principle of non-intervention, such as self-defence and intervention authorised by the UNSC. ${ }^{742}$ A State may also claim an exception to the principle of non-intervention if it can demonstrate State practice tending towards modification of the rule. ${ }^{743}$ However, the currently accepted exceptions do not apply to the low-lying States' scenarios. In Military and Paramilitary Activities in and against Nicaragua, the ICJ stated that: ${ }^{744}$

739 Friendly Relations Declaration, above n 226, at 123.

740 Resolution 2131, above n 247, at [1]-[2]; and see Friendly Relations Declaration, above n 226, at 123; Charter of the United Nations, art 2(4); and Montevideo Convention, art 8.

741 Non-interference in the internal affairs of States GA Res 31/91 (1976) at [1].

742 GR Berridge and Lorna Lloyd The Palgrave Macmillan Dictionary of Diplomacy (3rd ed, online, Macmillan Publishers, London) "intervention".

743 Nicaragua, above n 439, at 109.

744 At 108. 
A prohibited intervention must ... be one bearing on matters in which each State is permitted, by the principle of State sovereignty, to decide freely. One of these is the choice of a political, economic and cultural system, and the formulation of foreign policy. Intervention is wrongful when it uses methods of coercion in regards to such choices, which must remain free ones.

The Court also explained that, while military action is an obvious and overt form of coercion, indirect forms of coercion are also wrongful in light of the principle of non-intervention. ${ }^{745}$ The intention behind withdrawing recognition of statehood must be to coerce a low-lying State to concede its international legal personality for some advantage. This would undermine "the fundamental right of every State to survival", ${ }^{746}$ which reflects the right of its peoples to freely determine, without external interference, their political status. Therefore, withdrawing recognition is very likely to be interpreted as an indirect or possibly direct form of prohibited interference in a low-lying States' internal and external affairs.

Relating to this, Raič notes that when new States are recognised, this is also a recognition of its people's right to self-determination. ${ }^{747}$ If correct, this also implies that withdrawal of recognition of extant States might also amount to a breach of the "duty to promote, through joint and separate action, realization of the principle of equal rights and self-determination of peoples"748 and its "duty to refrain from any forcible action which deprives peoples ... of their right to self-determination and freedom and independence." 749

Overall, the low-lying States are solely competent to determine each of their own statehood statuses and withdrawal of recognition amounts to an interference in their internal affairs and self-determination. Therefore, withdrawal of recognition would not terminate a low-lying State's statehood.

\footnotetext{
745 At 108 .

746 Nuclear Weapons, above n 562, at 263.

747 Raič, above n 148, at 4217.

748 Friendly Relations Declaration, above n 226, at 123-124.

749 At 124.
} 
Given this conclusion, it will be unnecessary for third-party States to re-recognise low-lying States following relocation. However, positive acts could help "resolve uncertainties as to status and allow for new situations to be recognized". ${ }^{750}$ Re-recognition might also have a "reparative effect" for the unorthodox and damaging situations put upon the low-lying States and their peoples. ${ }^{751}$ A useful example of how this re-recognition could be approached comes from Belgium with respect to Latvia when it was restoring its independence following 50 years of occupation by the Soviet Union. The Belgian Minister of Foreign Affairs, Mark Eyskens, issued a press release in 1991 in which he declared that Belgium did not need to make a new act of recognition of the Baltic States because they are the continuity of States already recognised in $1920 .{ }^{752}$ In sum, it is unnecessary to recognise or even to say that recognition anew is unnecessary, but it is a gesture of good will that would be consistent with respecting and protecting low-lying States' statehood and self-determination.

\section{Conclusion}

In their relocation enterprise, each people is entitled to continuing statehood or to changing or forsaking legal personality. Ultimately though, those peoples are the decision-makers in this regard - it is not for others' determination - so there is no legal basis for statements by leaders of low-lying States that their sovereignty is at risk. ${ }^{753}$ Indeed, there is no legal milestone for terminating statehood at all. Therefore, it is unnecessary and unwise to start diplomatic negotiations with potential partner States from the starting point of fatalistic assumptions. A more prudent approach would be to assert their independence and entitlements in international law, along with the obligations on third-party States to cooperate and assist, as described in the previous chapter.

750 Crawford, above n 169, at 27.

751 Yamamoto and Esteban, above n 648, at 183.

752 Mark Eyskens, Minister for Foreign Affairs (BE) (press release, 23 August 1991), cited in Ineta Ziemele "The State Border between Latvia and Russia and the Doctrine of Continuity of the Republic of Latvia" (2009) 9 Baltic Y B Int'l L 95 at 98, fn 5.

753 For example, former President of Kiribati, Anote Tong, has said that "the reality [is] that their future as sovereign nations is in serious jeopardy": Tong, above $n$ 3. Also, as pointed out in Chapter 1, the former Maldivian President, Maumoon Abdul Gayoom, said that sea-level rise "would be the death of a nation": Gayoom, above n 5. 
The ILA's Committee on International Law and Sea Level Rise is considering this statehood question, but has not yet come to a view. ${ }^{754}$ Low-lying States are not represented on the Committee, ${ }^{755}$ but would be well advised to participate in the ILA's work to ensure it does not propose a one-size-fits-all "solution" that does not respect their rights to continuity and self-determination.

In any event, the statehood question does not exist in an international law vacuum and all relevant law points towards the low-lying States being exclusively competent to determine whether their statehood statuses continue ex situ. First, to maintain international stability, the presumption of statehood continuity permits States to persist without full satisfaction of statehood indicia. Secondly, self-determination is intimately related to statehood questions, and States have a duty to respect this right. Thirdly, international practice has afforded so-far unlimited flexibility as to whether, how, and to what extent all of statehood indicia criteria are satisfied for extant States. Fourthly, given that broad flexibility, there is potential for resolving how all these indicia are satisfied ex situ. Fifthly, withdrawal of recognition by other States has no legal effect on statehood and, in fact, amounts to a breach of the duty of non-interference. All these conclusions are harmonious and reinforce one another.

The feasibility in law of establishing statehood ex situ is supported by its feasibility as a matter of policy. The next chapter presents a range of options for enabling ex situ self-determination, including ex situ statehood, which are consistent with international law.

754 ILA Committee on International Law and Sea Level Rise Minutes of the Inter-sessional Meeting, Lopud, Croatia, 15-16 September 2017 (Chair: Professor David Vidas (Norway) (International Law Association, 2017).

755 ILA Committee on International Law and Sea Level Rise "List of Committee Members" < www.ilahq.org>. 


\title{
Chapter 5: Options for Enabling Self-Determination
}

\author{
"If we save the vulnerable, the rest of the world will be saved, too."756
}

\section{Introduction}

It has been demonstrated that the right to self-determination applies to the peoples of low-lying States, including in any future relocation enterprises. The next step is to consider how that right might be maintained ex situ, that is, in destination States. It is important to reiterate at the outset of this discussion that low-lying islanders do not want to be forced to leave their homes or home territories. ${ }^{757}$ Therefore, the first option must be third-party States taking adequate measures to mitigate climate change and provide the levels of support necessary to enable in situ adaptation. ${ }^{758}$ However, since levels of greenhouse gas emissions continue to rise ${ }^{759}$ despite of decades of scientific warnings, it is reasonable to assume that those preferred options will not eventuate. Furthermore, climate-related relocations are already happening, and they are occurring in a manner that could eventually undermine self-determination. ${ }^{760}$ Therefore, preparation and response measures are prudent.

Tuvalu's Prime Minister Sopoaga has explained that relocation "require[s] proper, well-planned interventions to support people in their efforts to adapt to the challenges." ${ }^{761}$ Moreover, cross-border relocations need to occur within a legal and policy framework that seeks to secure self-determination. This thesis has already outlined a number of

Olai Uludong, Palau's ambassador to the European Union, in Little, above n 42.

Niue Declaration, above n 7, at preamble, fifth recital; and Milan, Oakes and Campbell, above n 43, at 56.

See Wilton Park, above n 6, at [27].

Chelsea Harvey "CO2 Emissions Reached an All-Time High in 2018" (6 December 2018) Scientific American <www.scientificamerican.com>.

Chapter 1, Part III.

Debbie Singh "Regional meeting eyes Pacific climate migration and displacement" (7 December 2016) Asia Pacific Report <www.asiapacificreport.nz〉. Also, as Robinson observes, "the lawyers need to participate from the beginning of a takeoff in policy and not just in a crash landing whenever things go wrong": Davis R Robinson "The Reagan Administration (1981-1985)" in Scharf and Williams, above n 128, 55 at 55. 
practical and legal reasons why this is so: to mitigate risks associated with fragmenting populations $;{ }^{762}$ to overcome the sense of hopelessness purveyed by disaster narratives $;{ }^{763}$ to safeguard human rights; ${ }^{764}$ and to fulfil the various duties of actors on the international plane with respect to self-determination ${ }^{765}$ and statehood continuity. ${ }^{766}$

A one-size-fits-all model for ex situ self-determination would be ineffective, since each relocation enterprise will need to account for a myriad of practical, social, cultural and economic factors. Thus, what is presented here is a range of options, which are drawn from historical and contemporary examples in international and municipal law and practice. These options, which are summarised in Table 2 below, relate to first-order concerns: legal personality, land, and international frameworks. From these three categories, options can be assembled by policy-makers in various ways to create bespoke models for the peoples of each low-lying State. Moreover, all of the options are customisable, since they are unlikely to be directly transferable, and they are often not mutually exclusive.

The potential suitability of the case studies for the peoples of low-lying States is not assessed. That would involve substantial policy analysis. Instead, the case studies offer low-lying States and potential partner States exemplars from which they can identify elements that warrant further analysis.

One way of customising these options is to use self-determination as a central objective. This would create benchmarks for the relocation enterprise in the form of success indicators developed from the bundle of rights that comprise self-determination ${ }^{767}$ and from actors' respective duties. ${ }^{768}$ Thus, to this end, this chapter also proposes how to ensure a human rights-based approach to climate change adaptation incorporates

\footnotetext{
762 Chapter 1, Part III(B).

763 Perumal, above n 6, at 50.

764 Chapter 2, Part VI(A).

765 Chapter 3, Part VII.

766 Chapter 4, particularly Part VII.

767 Chapter 2, Part VII.

768 Chapter 3, Part II.
} 
self-determination. Finally, after discussing the options, two hypothetical scenarios are presented to illustrate how various combinations of options could be implemented.

Table 2. Options in international and municipal law and practice that might assist in enabling self-determination in climate relocation scenarios.

\section{Forms of legal personality}

- International legal

○ Statehood

personalities

- Free association or integration with another State:

- Free association and suzerainty

- Integration: federations

- Any other political status:

- Non-self-governing territories

- State-like entities

- Municipal entities

○ Trusts

○ Corporations

○ Incorporated societies

○ Sui generis juridical entities

\section{Land-holding options}

- Territory

○ Through cession

○ Shared sovereignty as a condominium

- Property

- Modes of acquisition
○ Purchase
○ Lease
- Enclaves and exclaves

- Freedom of movement and diasporic cosmopolitanism

\section{International frameworks}

- Multilateral agreements

- Soft law instruments and voluntary cooperation initiatives

- Regional programme

- Bilateral regime 


\section{Legal Personality: International and Municipal Forms}

The first category of options here is legal personality. This part sets out a range of options for legal personalities already present in international and municipal jurisdictions. Identifying a range of options is important because the futures of low-lying States are impliedly reduced to a "State or no State" binary in statehood commentaries that do not look towards alternatives. However, in a simplistic binary approach, if statehood is terminated, then what remains is a blunt lacuna; no clear legal mechanism through which the peoples' right to self-determination could be effectuated. Some writers have recognised this problem and considered alternative possibilities. In particular, Burkett explores in-depth the possibility of using the UN international trusteeship system as a model. ${ }^{769}$ Furthermore, a number of writers have noted that the Order of Malta, fragile States and governments-in-exile may also offer models for low-lying States ex situ. ${ }^{770}$ This part looks further at these, plus other international and domestic legal personalities.

The importance of a legal personality is that it would provide a mechanism through which each low-lying peoples could secure certain rights and duties in an ex situ scenario, which they could not obtain as individuals. Importantly, a legal person, or persons, would enable some degree-depending on the type of personality and the rules under which it is constituted - of political and administrative autonomy, which is at the heart of self-determination. ${ }^{771}$ This legal person would also function as a key mechanism for the people's collective ownership of public assets, such as administrative buildings, schools, and community hubs, for example, I-Kiribati maneaba ${ }^{772}$ and Tuvaluan maneapa or falekaupule. ${ }^{773}$ With a degree of autonomy, the legal person can also manage or govern

769 Burkett, above n 105, at 363.

770 For example, Burkett, above n 105, at 356-357; McAdam, above n 41, at 158; Rayfuse, above n 92, at 285-286; and Yamamoto and Esteban, above n 648, at 175.

771 Chapter 2, Part VII(B).

772 "At the centre of every village in Kiribati is a large, majestic building which is the focus of life in the community, known as the maneaba": Nakibae Tabokai "The Maneaba System" in Van Trease (ed), above $n$ 364, 23 at 23.

773 Public meeting houses are known as maneapa or falekaupule: Marc Beaulieu "Tuvaluan Faatele: A Performative and Historico-geographic Context" (2009) 34 Context 49 at 52. "The Falekaupule is the 'house of knowledge' and is traditionally a place where the community conducts its meetings and holds 
those assets in accordance with the people's norms and other constraints. A legal person may also have standing to bring an action against the partner State or another party that it believes has infringed upon its entitlements and those of the collective people it represents. The legal person would likely have perpetual succession, rules regarding the selection and appointment of decision-makers, and the capacity to enter into contracts and other agreements, allowing the people to access goods, services, and funding, including global adaptation finance and bilateral development assistance, where it is a qualifying international legal person.

With respect to low-lying States' choices for legal personality, Willcox employed the three-pronged framework in the Friendly Relations Declaration, which states that: ${ }^{774}$

\footnotetext{
The establishment of a sovereign and independent State, the free association or integration with an independent State or the emergence into any other political status freely determined by a people constitute modes of implementing the right of self-determination by that people.
}

This part discusses options relative to the Friendly Relations Declaration categories, then considers municipal personalities, and the effects of having no legal personality. The options are presented in an approximate order of the most to the least prospects for securing ex situ self-determination.

\section{A. A Sovereign and Independent State}

The first possible legal personality for low-lying peoples is statehood. The analyses presented earlier in this thesis concluded that, in the case of relocation, a low-lying people remain exclusively competent to determine whether they retain statehood or freely adopt an alternate personality. This is due to the presumption of continuity, their right to self-determination, and other States' duties to respect and protect that right. These factors

its celebrations": Ministry of Social Development (NZ) Nga vaka o käinga tapu: A Pacific Conceptual Framework to address family violence in New Zealand (March 2012) at 9.

774 Friendly Relations Declaration, above n 226, at 124; Willcox, above n 162, at 149; and Resolution 1541, above n 424, at Principle VI. 
enable statehood to persist despite less than complete satisfaction of the Montevideo Convention's indicia for establishing new States.

The potential for ex situ statehood is reinforced further by the potential for innovative solutions for protecting or re-acquiring the orthodox statehood indicators, territory, population, government, and capacity for international relations. Statehood can and should continue despite less than full satisfaction of the Montevideo indicia, but they can still be complied with ex situ. For instance, part III of this chapter discusses various options for acquiring land that can help satisfy territory expectations. And in terms of a permanent population, Burkett identifies that diasporic populations may remain meaningfully connected through a cosmopolitanism framework, ${ }^{775}$ which would no doubt be bolstered if there were a "population nucleus", as Stoutenburg has posited. ${ }^{776}$

All of this is feasible because "[t]he State - a legal constituent fiction - is a question of fact". ${ }^{777}$ Ultimately, a State is a human construct; an artificial legal construct. It can be constructed and reconstructed in whatever ways suit complex and evolving requirements. A package of innovations to this legal construct could help ensure low-lying States' ex situ continuity, which has been referred to as "deterritorialised States"778 and "nations ex situ". ${ }^{779}$ Statehood is not, of course, the only class of international legal personality. ${ }^{780}$ Low-lying States might choose to transform into one or more of the several alternative legal persons, whether international, municipal, or both.

\section{B. Free association or integration with another State}

After statehood, the Friendly Relations Declaration provides for "free association or integration with an independent State" as the next mode of implementing the right to

\footnotetext{
775 Burkett, above n 105, at 358-360.

776 Stoutenburg, above n 127, at 65. See also Part III(G) of this chapter.

777 Anzar-Gómez, above n 255, at 50.

778 Rayfuse, above $\mathrm{n} 92$, at 281.

779 Maxine A Burkett "The Nation Ex-Situ" in Gerrard and Wannier, above n 127, 89 at 89-90.

780 See generally Shaw, above n 91, at 142-143 and chapter 5.
} 
self-determination by a people on the international plane. ${ }^{781}$ Free association arrangements include free association per se, as well as suzerainties, and integration includes federations and consociationalism.

\section{Free Association and Suzerainty}

Free association involves a State managing its own affairs while also having a special relationship with another State, which involves such things as shared citizenship and defence. ${ }^{782}$ A State in free association is neither integrated with the other State nor entirely independent from it.

Contemporary and historical models of free association could provide low-lying States with guidance on how their affairs may be arranged relative to a partner State. Indeed, one of the low-lying States, the Marshall Islands, already has a Compact of Free Association with the United States, in which it is a sovereign State but the United States has assumed responsibility for their defence. ${ }^{783}$

Another example is Niue, whose arrangements eventuated after a majority of voters voted in favour of the referendum question, "Do you vote for self-government for Niue in free association with New Zealand on the basis of the Constitution and the Niue Constitution Act 1974?". ${ }^{784}$ Niue is "a sovereign State". ${ }^{785}$ However, the bespoke arrangement is "different from full independence", ${ }^{786}$ with Niue remaining within the See also Caroline Jenny McDonald "Decolonisation and Free Association: The Relationship of the Cook Islands and Niue with New Zealand" ( $\mathrm{PhD}$ dissertation, Victoria University of Wellington, 2018) at 30-31; and Fred M Zeder II "Understanding Free Association as a Form of Separate Sovereignty and Political Identity in the Case of Decolonization of Puerto Rico" Puerto Rico Herald <www.puertorico-herald.org>.

783 RMI-US Compact of Free Association, above n 472, s 311.

784 Salote Talagi "Niue" in Levine, above n 346, 188 at 189.

785 A H Angelo "The Niue Constitution" (2009) 15 Revue Juridique Polynésienne 157 at 159.

786 Ministry of Foreign Affairs and Trade (NZ) "Niue" <www.mfat.govt.nz>. Compare Angelo, above $n$ 785 , at 160 . 
Realm of New Zealand. ${ }^{787}$ As part of this relationship: New Zealand can enact legislation that extends to Niue, but only if requested and consented to by the Niue Assembly; ${ }^{788}$ New Zealand provides economic, administrative, and defence assistance, ${ }^{789}$ and Niueans are New Zealand citizens who are free to reside and work in New Zealand. ${ }^{790}$ At the same time, Niue has diplomatic relations with other States, including New Zealand; it is a member of international organisations, such as UNESCO, ${ }^{791}$ and regional organisations, including the PIF ${ }^{792}$ and is a signatory to international treaties. ${ }^{793}$

There are challenges for Niue in this arrangement. For instance, with free movement, many Niueans have relocated to New Zealand, with the local population declining from around 5,100 in the 1970 s to around 1,500 today. ${ }^{794}$ By comparison, New Zealand is home to approximately 24,000 Niueans, ${ }^{795}$ almost 80 per cent of whom were born in New Zealand. ${ }^{796}$ Many of them are unlikely to be able to vote in Niuean elections due to requirements that a person has, at some point, resided continuously in Niue for at least three years, and they have been resident in Niue throughout the 12 months immediately preceding an application for enrolment to vote. ${ }^{797}$ These issues have raised questions about whether Niue could be viable as a fully independent State. ${ }^{798}$

An alternative form of association is a suzerainty, which is further along the spectrum away from independence. It is: ${ }^{799}$

787 Letters Patent Constituting the Office of the Governor-General of New Zealand (28 October 1983), SR 1983/225, art 1(c); and see Angelo, above n 785, at 160.

788 Constitution of Niue (1974), s 36(1).

789 McDonald, above n 782, at 102.

790 Ministry of Foreign Affairs and Trade (NZ), above n 786.

791 UNESCO "Member States List" <www.unesco.org>.

792 Pacific Islands Forum Secretariat "The Pacific Islands Forum" <www.forumsec.org >

793 United Nations "United Nations Treaty Series Online" <treaties.un.org>.

794 New Zealand Geographic "Virtual Reality: Niue" <www.nzgeo.com>.

795 Ministry of Foreign Affairs and Trade (NZ), above n 786.

796 Statistics New Zealand "2013 Census ethnic group profiles - Niuean" <www.stats.govt.nz>.

797 Constitution of Niue, s 17(1)(a).

798 McDonald, above n 782, at 153.

799 Berridge and Lloyd, above n 742, at "suzerainty". See also Prabhakar Menon "Book Review: Claude Arpi, Tibet: The Last Months of a Free Nation: India Tibet Relations (1947-1962) Part I, (New Delhi, 2017, VIJ Books)" (2017) 12(4) Indian Foreign Affairs Journal 355 at 356. 
A situation in which one sovereign state exercises an acknowledged and significant degree of supremacy over another, often on the basis of a treaty between them, but possibly on a political basis alone.

A suzerainty is controversial when it is imposed on an extant State under the auspices of humanitarian intervention, such as the 2003 invasion of Iraq. ${ }^{800}$ However, the concept persists in other, less controversial situations. For example, in decolonisation, a budding State can enjoy formal independence but not full factual independence while it remains under guidance from another State, an international organisation, or both. ${ }^{801}$

For the low-lying States, free association and suzerainty may serve as theoretical models for legal personality and power sharing. For example, the low-lying State may devolve to the partner State the authority to conduct certain affairs of State, whether relating to international relations, domestic affairs, or both. The case of Niue is particularly interesting since Niue exists as its own international legal person with what might be described as a "population nucleus" living in the single atoll but a majority population living in mainland New Zealand.

\section{Integration: Federations}

Another class of legal personality is "integration with an independent State", as it is described in the Friendly Relations Declaration. Considering the situations for low-lying States, Park explains that such unions can "result in the creation of a new State or lead to one State being subsumed into an existing State." ${ }^{802}$ Summarising Resolution $1541,{ }^{803}$ Hannum explains: ${ }^{804}$

\footnotetext{
800 See generally Heriberto Cairo "The Duty of the Benevolent Master: From Sovereignty to Suzerainty and the Biopolitics of Intervention" (2006) 31 Alternatives 285.

801 Crawford, above n 169, at 66.

802 Park, above n 28, at 18.

803 See above n 424, Principles VIII and IX.

804 Hannum, above n 1, at 40.
} 
Integration must be on the basis of 'complete equality' between peoples of the territory and the country they are joining ... chosen with 'full knowledge' and through democratic processes 'impartially conducted and based on universal adult suffrage'.

A primary means by which integration may be facilitated is through a federation. In a federation, a single State is comprised of the State-wide federal government plus sub-State governments that may be referred to as provinces, states, départements, regions, or cantons. ${ }^{805}$ Individual federal States divide and share sovereignty and power among the constituent parts of the federation differently. ${ }^{806}$ For example, in some instances, the borders dividing these sub-State entities may be arbitrary historical relics, or they may reflect distinct communities, as in the case of Switzerland (discussed further below). In the latter cases, Guibernau notes that: ${ }^{807}$

... the mere creation of federal structures does not necessarily lead to a federalism which assumes both respect for diversity and a strong commitment to accept the union of the federation.

Kymlicka explains the two sides of the coin. ${ }^{808}$ On the one hand, federalism carries risks, such as the reification and 'ownership' of culture by groups' political leaders. ${ }^{809}$ But, on the other hand, it is a way "to acknowledge and legitimize the political mobilization of ethnicity, [and] to channel this mobilization in peaceful and democratic ways." 810 This can lead to groups living alongside one another, peacefully, in "parallel societies" ${ }^{811}$ multination States, ${ }^{812}$ or "multination and multilingual federalism". ${ }^{813}$

805 Montserrat Guibernau Nations without States: Political Communities in a Global Age (Polity Press, Cambridge, 1999) at 50.

806 At 38 and 50.

807 At 50 .

808 Will Kymlicka "Transitional Justice, Federalism, and the Accommodation of Minority Nationalism" in Paige Arthur (ed) Identities in Transition: Challenges for Transitional Justice in Divided Societies (Cambridge University Press, Cambridge, 2011) 303.

809 At 307.

810 At 305.

811 At 306.

812 At 308 .

813 At 309. 
There are many federations that may offer guidance to low-lying States, ${ }^{814}$ but an interesting example is Switzerland. The 1848 constitution confirmed Switzerland's government as being a confederation of its 22 "sovereign Cantons". ${ }^{815}$ A confederation differs from a general federation insofar as the central or national government is subservient to the member states that remain autonomous. Thus, the 1848 constitution enabled the Cantons "to preserve their individual identities, even a certain patriotism, to the point that they could be considered microstates." 816 The 1999 Swiss constitution has more similarities to a general federation than a confederation, since "Federal law takes precedence over contrary cantonal law" and "[t]he Confederation shall ensure that the Cantons respect federal law." 817 However, the confederation ideal remains prominent, with the now-26 Cantons recognised as "sovereign except to the extent that their sovereignty is limited by the Federal Constitution." ${ }^{818}$ With these power-sharing arrangements, Schmitt argues that: 819

Switzerland is not a nation in the traditional sense of the term but a willensnation [willed nation] forged by the desire of its citizens to renew constantly the links that unite them ... It is this very unity in diversity that makes Switzerland a paradigm of political integration.

The potential for fracture between Cantons is recognised and sought to be addressed in the Swiss Constitution, which sets out principles of cooperation: ${ }^{820}$

1. The Confederation and the Cantons shall collaborate, and shall support each other in the fulfilment of their tasks.

2. They owe each other mutual consideration and support. They shall grant each other administrative and judicial assistance.

See generally John Kincaid and G Alan Tarr (eds) Constitutional Origins, Structure, and Change in Federal Countries (McGill-Queen's University Press, Montreal and Kingston, 2005).

Federal Constitution of the Swiss Confederation 1848, art 1.

Nicolas Schmitt "Swiss Confederation" in Kincaid and Tarr (eds), above n 814, 348 at 351-352.

Federal Constitution of the Swiss Confederation 1999, art 49(1)-49(2).

Article 3.

Schmitt, above n 816, at 348. Willesnation means 'willed nation'.

Art 44. 
3. Disputes between Cantons, or between Cantons and the Confederation shall, to the extent possible, be resolved through negotiation or mediation.

For a low-lying people or State relocating to a partner State, federalism might come about by having their State integrate with a partner State. If an objective of the agreement is the low-lying people's enjoyment of self-determination, then a bilateral agreement implementing the federation would need to delineate competencies to that effect. This will involve the low-lying people enjoying a degree of autonomy. ${ }^{821}$ Thus, the agreement might also seek to balance or address the ways in which that autonomy risks concretising differences in ways that lead to tensions and conflict. It will also need dispute resolution mechanisms for any disputes between intra-federation governments.

Another model of integration is consociationalism, or consociational democracy. This is "government by elite cartel designed to turn a democracy with a fragmented culture into a stable democracy." ${ }^{822}$ As Lijphart explains, it is "the deliberate joint effort by the elites to stabilize the system", ${ }^{823}$ that is, a social system beset by "crosscutting cleavages". ${ }^{824}$ These cleavages might derive from "ideology, religion, class, language, or ethnicity", and may risk destabilising the democracy. ${ }^{825}$ Essentially, therefore, a consociational democracy is a system where there is a degree of autonomy for heterogenous subgroups, which may not be spatially separate, as in the cases of cantons and provinces. Sub-groups' leaders are elected into a central system in such a fashion that it facilitates stability. These systems have four central features: the leaders of subgroups join together in a "grand coalition" government; ${ }^{826}$ the subgroups have a degree of sub-system autonomy; ${ }^{827}$ there is proportionality in respect of voting and public sector employment; ${ }^{828}$ and there are various forms of administrative and governance apparatus

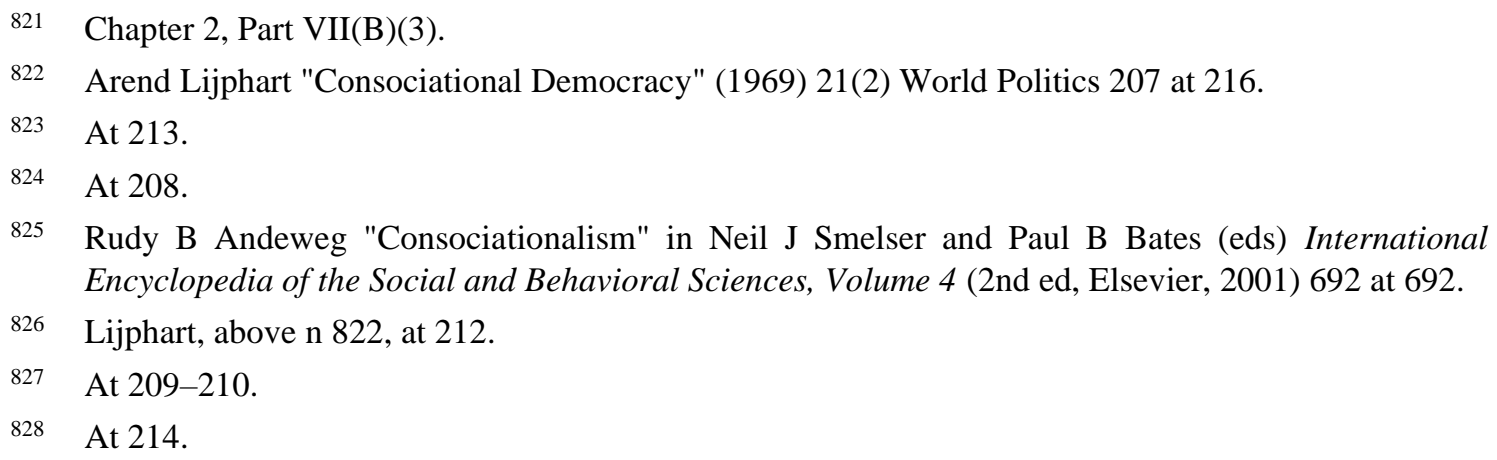


to limit the impact of overarching majority rule structures. ${ }^{829}$ The States that are or have been consociational democracies include: ${ }^{830}$

\begin{abstract}
Austria (1945-66), Belgium (from 1918), Bosnia-Herzegovina (since 1995), Burundi (since 2005), Canada (1840-67), Colombia (1958-74), Cyprus (1960 and 1963), Czechoslovakia (1989-1993), India (1947 to the late 1960s), Lebanon (1943-75 and after 1989), Luxembourg, Malaysia (1955-1969 and since 1971), Macedonia (since 2000), the Netherlands (1917-1967), Northern Ireland (after 1998), South Africa (1993-96), and Switzerland (since 1943), with contemporary Canada and Israel being classified as semiconsociational.
\end{abstract}

A modern example of a consociational federation is Bosnia and Herzegovina $(\mathrm{BiH})$, which illustrates a means by which power sharing might be organised among sub-national groups. In order to "establish durable cessation of hostilities", the General Framework Agreement for Peace in Bosnia and Herzegovina (the Dayton Peace Accords) divided the country in two main ways. ${ }^{831}$ The first is between two Entities: the Federation of Bosnia and Herzegovina (FBiH), and the Republika Srpska ('Serb Republic'). ${ }^{832}$ These Entities enjoy "wide-ranging powers of self-government". ${ }^{833}$ The second division is within the $\mathrm{FBiH}$ only. It has ten Cantons operating under the constitution and laws of the $\mathrm{FBiH}$ but which also "have their own Constitution, Parliament, Government and judicial powers". ${ }^{834}$ The architects of the Dayton Peace Accords devised this model aiming to "guarantee the political representation of each national group at the institutional level, to promote the groups' rights to self-government, and to promote inter-ethnic accommodation and compromise." ${ }^{835}$ The model also includes proportional representation as well as ethnic quotas, which guarantee representation in all levels of

At 214-215.

Andeweg, above n 825, at 692.

The General Framework Agreement for Peace in Bosnia and Herzegovina (signed 14 December 1995) (Dayton Peace Accords), art 2(a).

Francine Friedman Bosnia and Herzegovina: A polity on the brink (Routledge, London, 2004) at 58.

Roberto Belloni "Peacebuilding and Consociational Electoral Engineering in Bosnia and Herzegovina" (2004) 11(2) International Peacekeeping 334 at 336.

European Committee of the Regions "Division of Powers: Bosnia and Herzegovina" <cor.europa.eu>.

Belloni, above n 833, at 336. 
government. ${ }^{836}$ The particular post-war situation of $\mathrm{BiH}$ has meant that this federation model has not solved all nationalism-related problems and the country still faces significant challenges. ${ }^{837}$ However, for the low-lying States' purposes, it provides an interesting contrast to other federation models, such as those of Australia or the United States, because the $\mathrm{BiH}$ model is aimed specifically at protecting ethnic groups.

For low-lying States relocating into the territory of partner States, the federal and consociational models demonstrate conceptual and normative arrangements for sharing sovereignty. Such a model might be effectuated, at least in part, through the competencies and rights of the low-lying people and their nation's legal personality. For example, with the option of integrating with another State, the low-lying State may become one of the autonomous subgroups that have a place in a "grand coalition" with the government of the partner State.

\section{C. "Any other political status": Non-Self-Governing Territories and State-like Entities}

The final mode of implementing self-determination provided for in the Friendly Relations Declaration is "the emergence into any other political status freely determined by the people". ${ }^{838}$ If the self-determination of peoples is the highest priority rather than statehood per se, there exists a range of other international legal personalities that low-lying States may wish to consider, in particular, the State-like entities. States remain the primary subjects of international law, and thereby enjoy the widest range of rights and privileges. Therefore, changing into an alternative international legal personality with a lesser degree of sovereignty and independence would involve losses with respect to States' rights and privileges. ${ }^{839}$ But, if change is required, these alternatives at least offer continued participation on the international plane.

\footnotetext{
836 At 336.

837 See generally Belloni, above n 833; and Friedman, above n 832.

838 Friendly Relations Declaration, above n 226, at 124.

839 Lassa Oppenheim International Law: A Treatise: Volume I: Peace (Longmans, Green and Co, London, 1905), § 290, 344; and Shaw, above n 91, at 142.
} 
Some non-State international legal personalities are very unlikely to be applicable to low-lying peoples' ex situ self-determination, such as international and regional organisations. However, some models could be adopted to enable low-lying peoples' ex situ self-determination, probably in modified form. In particular, there are "entities legally proximate to States" and "entities sui generis" on the international plane. ${ }^{840}$ Some of these entities have been identified previously as possible models for low-lying States, particularly the Order of Malta, given its complete lack of territory, ${ }^{841}$ and the NSGT model, which has been examined closely by Burkett. ${ }^{842}$ Here, these and other models are discussed to highlight important specifics of international rights and privileges or internal autonomy maintained and lost in these models.

The State-like entities considered here are: NSGTs, focusing on the case study of Tokelau; the Holy See; the Order of Malta; and the Free City of Danzig. An important general point from these case studies is that each of their historical, social and political circumstances gave rise to their individual legal forms, and each model enjoys some, but not all, of the rights, privileges and obligations of statehood. Their uniqueness demonstrates the degree of flexibility available to low-lying States should they seek "any other political status" other than statehood or integration with another State as their means of protecting self-determination.

\section{Non-Self-Governing Territories}

Although it has only been applied to subjects of decolonisation to date, an NSGT status could, at least theoretically, be a political status freely determined by a people as a mode of implementing self-determination. ${ }^{843}$ It is "a status separate and distinct from the territory of the State administering it", ${ }^{844}$ and also "distinct ethnically and/or culturally". ${ }^{845}$ For these and other reasons, Burkett has identified the potential to deploy

Crawford, above n 91, at 117 and 124-125.

For example, Rayfuse, above n 92, at 10.

Burkett, above n 105, at 363-367.

Friendly Relations Declaration, above n 226, at 124.

At 124.

Resolution 1541, above n 424, Principle IV. 
the NSGT trusteeship model to the low-lying States. ${ }^{846}$ While low-lying peoples may be dispersed, Burkett suggests their government could persist ex situ with the support of the trusteeship model. This way, the supported government could act as the key connection between diasporic communities and, thereby, help enable continuity of culture and other aspects of nationhood and wellbeing. ${ }^{847}$

An objective for NSGTs is developing self-government. ${ }^{848}$ The UN maintains a "decolonisation list" that currently has 17 NGSTs, down from 72 when the UN was established in $1945 .^{849}$ The Charter sets out the responsibilities of States within which NSGTs exist. Article 73 provides:

\begin{abstract}
Members of the United Nations which have or assume responsibilities for the administration of territories whose peoples have not yet attained a full measure of self-government recognize the principle that the interests of the inhabitants of these territories are paramount, and accept as a sacred trust the obligation to promote to the utmost, within the system of international peace and security established by the present Charter, the well-being of the inhabitants of these territories ...
\end{abstract}

To this end, Article 73 imposes obligations on such Members, including the political, economic, social and educational advancement of the people within the territory, ${ }^{850}$ and the transmission of regular reports to the UN Secretary-General. ${ }^{851}$ The Charter obliges the administering State: 852

... to develop self-government to take due account of the political aspirations of the peoples, and to assist them in the progressive development of their free political institutions, according to the particular circumstances of each territory and its peoples and their varying stages of advancement.

Burkett, above n 105, at 363 .

At 359-360 and 363 .

Charter of the United Nations, article 73(b).

United Nations "The United Nations and Decolonization: Non-Self-Governing Territories" <www.un.org>.

Charter of the United Nations, Article 73(a).

Article 73(e). Instructive in this regard is Resolution 1514, above n 208.

Article 73(b). 
In the context of NSGTs and their progress towards self-government (as opposed to the low-lying States' endeavours to maintain that authority), Resolution 1541 specifies important procedural and substantive entitlements, which closely resemble those regarding self-determination. It states that: 853

(a) Free association should be the result of a free and voluntary choice by the peoples of the territory concerned expressed through informed and democratic processes. It should be one which respects the individuality and the cultural characteristics of the territory and its peoples, and retains for the peoples of the territory which it is associated with an independent State the freedom to modify the status of that territory through the expression of their will by democratic means and through constitutional processes.

(b) The associated territory should have the right to determine its internal constitution without outside interference, in accordance with due constitutional processes and the freely expressed wishes of the people. This does not preclude consultations as appropriate or necessary under the terms of the free association agreed upon.

Whilst the general direction and the strong preference of the UN is that these processes bring about full independence, a people may opt for alternative free political institutions with different relationships with administering States and different degrees of independence. This may be an appropriate development since we are largely beyond the post-World War II decolonisation context and into the 21 st century, climate change context.

The low-lying coral atoll territory of Tokelau is an NSGT. Since it is not a State, Tokelau is a territory of, and is administered by, New Zealand. The Head of State of Tokelau is the Queen of New Zealand, as represented by the Governor-General of New Zealand. It has its own law-making body, the General Fono, which is responsible for such matters as the budget, international affairs (for example, Tokelau is an Associate Member of the PIF and an Observer Member of the Polynesian Leaders Group), health and education policy, and Tokelau's relationship with New Zealand. Overall, Tokelau has moved to an "advanced level of political self-reliance", although its economy remains 
heavily dependent on New Zealand. ${ }^{854}$ From New Zealand's perspective, the relationship is managed by an Administrator of Tokelau, who is appointed by the New Zealand Ministry of Foreign Affairs and Trade, and is currently based in Auckland. ${ }^{855}$ Tokelauans have twice voted against full independence in referenda in 2006 and 2007. Therefore, in exercising self-determination, Tokelauans have freely determined their political status, which is to maintain the NSGT status with New Zealand.

The General Assembly has recognised an emerging additional complication with respect to Tokelau's potential independence: "that the self-determination process of the Territory could not be addressed in isolation from the threat of climate change and the rise in sea level". ${ }^{856}$ Like the low-lying States, climate change may necessitate the relocation of the entire population in the longer-term. ${ }^{857}$ However, unlike the low-lying States, Tokelau is not a State and Tokelauans have a clear legal solution, which is free movement to New Zealand as New Zealand citizens. Nevertheless, this climate relocation carries many of the same risks that low-lying States face regarding nationhood and its manifestations, including loss of the General Fono and other political, legal and cultural systems important for maintaining nationhood.

Tokelau's NSGT model is premised upon a physically separate territory, among other things, so it is not a directly translatable case study for relocating peoples from low-lying States. Nonetheless, certain elements of the Tokelauan NSGT model may be relevant to low-lying States. To begin with, the NSGT status is internationallyrecognised, subject to international oversight by the UN through its Special Committee on Decolonization. Therefore, a low-lying State that changes to an NSGT would exist on the international plane and the partner State's activities would be scrutinised by the international community. As the relationship between Tokelau and New Zealand evidences, this status also creates a special relationship between the peoples who have the

\footnotetext{
854 Ministry of Foreign Affairs and Trade (NZ), above n 28.

855 Ministry of Foreign Affairs and Trade (NZ), above n 28; and Winston Peters "Administrator of Tokelau announced" (press release, 15 December 2017).

856 Question of Tokelau GA Res 71/107, A/Res/71/107 (2016) at preamble, twelfth recital.

857 Campbell, Goldsmith and Koshy, above n 409, at 41.
} 
right to self-determination and their State, but also a very high degree of political and functional independence. However, there are limitations. Notably, Tokelau is unable to independently access multilateral fora that require participants to be States. For example, the Government of Tokelau had to ask New Zealand to extend the territorial application of the UNFCCC and Paris Agreement to Tokelau. ${ }^{858}$ Also, New Zealand provides Tokelau's funding via its bilateral aid programme rather than mainstream public funding. ${ }^{859}$ Therefore, there is a high degree of dependency on the administering State. However, a low-lying State and a partner State could negotiate different demarcation of rights and responsibilities. Moreover, as the NSGT model is based on territory, that issue would remain to be resolved, but options in that respect are discussed in part III of this chapter.

\section{The Holy See}

In the 1929 Lateran Pacts, the Holy See and Italy agreed on the former's "absolute independence", its "indisputable sovereignty in international matters", and its "full ownership, exclusive dominion, and sovereign authority and jurisdiction ... over the Vatican". ${ }^{860}$ There can be little doubt, therefore, that these two entities imagined the Holy See would enjoy something resembling statehood, if not statehood itself. As a consequence, the Holy See is a Permanent Observer (Non-state Member) of the UN; ${ }^{861}$ it participates in international treaty negotiations on an equal footing with States; it maintains diplomatic relations with 183 states, the European Union and the Order of

859

James Shaw "Global climate change agreement extended to Tokelau" (press release, 14 November 2017).

Ministry of Foreign Affairs and Trade (NZ) "Aid partnership with Tokelau" <www.mfat.govt.nz>.

Treaty Between the Holy See and Italy in the Name of the Most Holy Trinity (1929), at preamble, first and second recital, and article 3.

Participation of the Holy See in the work of the United Nations GA Res 58/314, A/RES/58/314 (2004). 
Malta; ${ }^{862}$ it is a signatory to numerous multilateral and bilateral agreements, including the VCLT and the Geneva Conventions ${ }^{863}$ and it asserts immunities. ${ }^{864}$

Despite these facts, debates persist over the Holy See's status, largely because there is no self-perpetuating, coherent, stable community needed to satisfy the population criteria. ${ }^{865}$ Progressing on the assumption that the Holy See is not a State but rather a State-like entity, the interest for low-lying States is in the model of rights and responsibilities illustrated by this entity rather than settling the statehood debate. It is clear that the Holy See enjoys some form of international legal personality. That form endows it with competence to participate extensively in international fora. It can do this even without a permanent population and with 'territory' that is a mere 0.44 square kilometres. Thus, low-lying States may seek to adopt an international legal personality analogous to the Holy See, based on a small "population nucleus" and diminutive land holdings.

\section{The Order of Malta}

The Order of Malta was originally a hospital established in 1048 to care for pilgrims, but became sovereign by papal decree in $1113 .{ }^{866}$ It was sovereign in Cyprus (1291-1310), Rhodes (1310-1523) then Malta (1538-1798), but surrendered its territory

862 Vatican City State "Diplomatic Relations " <www.vatican.va>.

863 Geneva Convention for the Amelioration of the Condition of the Wounded and Sick in Armed Forces in the Field (First Geneva Convention) (signed 12 August 1949, entered into force 21 October 1950) 75 UNTS 31; Geneva Convention for the Amelioration of the Condition of Wounded, Sick and Shipwrecked Members of Armed Forces at Sea (Second Geneva Convention) (signed 12 August 1949, entered into force 21 October 1950) 75 UNTS 85; Geneva Convention Relative to the Treatment of Prisoners of War (Third Geneva Convention) (signed 12 August 1949, entered into force 21 October 1950) 75 UNTS 135; and Geneva Convention Relative to the Protection of Civilian Persons in Time of War (Fourth Geneva Convention) (signed 12 August 1949, entered into force 21 October 1950) 75 UNTS 287.

864 Emma Green "A Vatican Diplomat Has Been Recalled From the U.S. Following Child-Pornography Charges" (15 September 2017) The Atlantic <www.theatlantic.com>; and Philip Puellella "Pope will have security, immunity by remaining in the Vatican" (16 February 2013) Reuters <www.reuters.com>.

Morss, above n 576, at 931; Robertson, above n 654, at [116]-[117]; and see Chapter 4, Part VI(B).

Karol Karksi "The International Legal Status of the Sovereign Military Hospitaller Order of St. John of Jerusalem of Rhodes and of Malta" (2012) 14 International Community Law Review 19 at 20; Cathal J Nolan The Greenwood Encyclopedia of International Relations (Greenwood Publishing, Westport CT, USA, 2002) at "Sovereign Military Order of Malta"; and Order of Malta "1048 to the present day" <www.orderofmalta.int>. 
to Napoleon in 1798. Since then, the Order of Malta has had no territory. It does, however, have properties, including a "government seat" in Rome, the Magistral Palace, to which Italy granted "extraterritorial rights". ${ }^{867}$ Its 1961 Constitutional Charter states, "[t]he Order is a subject of international law and exercises sovereign functions." ${ }^{868}$ Thus, it does not claim to be a state, and it is not recognised as such. ${ }^{869}$ However, the Order of Malta does enjoy certain rights due to being recognised as having sui generis international legal personality. ${ }^{870}$ For example, it is a non-State permanent observer to the UN (along with Palestine), ${ }^{871}$ which gives the Order of Malta "free access to most meetings and relevant documentation." 872 It also has diplomatic relations with 108 States and the European Union, ${ }^{873}$ plus "cooperation agreements" with "more than 50 States" to enable its humanitarian activities. ${ }^{874}$ Since it is not a State, the cooperation agreements do not amount to treaties governed by international law, ${ }^{875}$ but resemble the cooperation agreements and memorandums of understanding that international and non-government organisations enter into with States to enable humanitarian and other work in those States' territories. ${ }^{876}$

For low-lying States, if statehood is undermined by global political decisions, they may seek to change to a "sovereign entity" resembling the Order of Malta. Their rights and privileges would be diminished, but they would be able to maintain some degree of multilateral and bilateral relations that support the entity's purposes, including enabling their people's self-determination.

\footnotetext{
867 Order of Malta "The government seat of the Sovereign Order of Malta" <www.orderofmalta.int>.

868 Constitutional Charter and Code of the Sovereign Military Hospitaller Order of St. John of Jerusalem of Rhodes and of Malta (1961), article 3(1).

869 Karksi, above n 866, at 21; and Nolan, above n 866.

870 Karksi, above n 866, at 21.

871 United Nations, above n 656.

872 United Nations "About Permanent Observers" <www.un.org>.

873 Order of Malta "Bilateral Relations" <www.orderofmalta.int>.

874 Sovereign Military Hospitaller Order of St John or Jerusalem of Rhodes and of Malta "A brief description of its sovereignty, diplomacy, government and history" (1 March 2018) at 2.

875 VCLT, art 2(1)(a).

876 For example: International Federation of the Red Cross and Red Crescent Societies "Working partners" <www.ifrc.org>.
} 


\section{4. $\quad$ Free City of Danzig}

Situated in modern-day Gdańsk, Poland, the tenuous and ultimately short-lived Free City of Danzig existed from its establishment via the 1919 Treaty of Versailles ${ }^{877}$ until annexation by Germany in $1939 .{ }^{878}$ The objective of negotiators at the end of the First World War was not to establish the Free City as a State, but to ensure Poland had free access to waterways for imports and exports ${ }^{879}$ in an area with a 90 per cent German population. ${ }^{880}$ Thus, Danzig enjoyed certain characteristics of statehood, but was limited in other ways. For example, it enjoyed a defined territory, ${ }^{881}$ its own citizens, ${ }^{882}$ and certain powers to make treaties. ${ }^{883}$ However, Poland was authorised to conduct foreign relations and diplomatic protection of the citizens of Danzig, ${ }^{884}$ and rather than its own representative government, the Free City was under the protection of the League of Nations ${ }^{885}$ with a Commission established by the Allied Powers. ${ }^{886}$

The Free City of Danzig held a "special juridical status" with a degree of international legal capacity and autonomy, as recognised by the PCIJ. ${ }^{887}$ Thus, for the purposes of relocating low-lying peoples, a low-lying State might transform into a juridical entity with similarly limited autonomy, delegate foreign relations and diplomatic protection to its partner State, and conduct its affairs under guidance and supervision of the UN.

Treaty of Versailles, art 102.

Michael Fry "Danzig and the Beginnings of World War II" (28 August 2014) National Geographic <www.nationalgeographic.org>.

Treaty of Versailles, art 104(2).

Izabela Olszewska "Cultural Identity of Citizens of Gdansk from an Ethnographic Perspective on the Basis of Chosen Texts of the Free City of Danzig" (2013) 2 Colloquia Humanistica 133 at 134.

Treaty of Versailles, art 100.

Article 105-106.

Article 104.

Article 104(6).

Article 102.

Article 1010-102.

Free City of Danzig and International Labour Organization (Advisory Opinion) (1930) PCIJ (series B) No 18 at 11 . 


\section{Concluding on State-like entities}

NSGTs, the Holy See, the Order of Malta, and the Free City of Danzig illustrate that it is possible for low-lying States to have some form of international legal personality which, while less than statehood, confers various degrees of autonomy and legal capacity. Furthermore, these entities illustrate that the question is not as blunt as "statehood or nothing". There are State-like entities that may meet some of the needs and wishes of low-lying peoples should statehood not be feasible. Moreover, the uniqueness of each of these models demonstrates that low-lying States can invent new State-like entities. As Worster explains: $:^{888}$

\footnotetext{
$\ldots$ there is no reason ... why there cannot be other international legal persons ... In principle, it is simply a choice of the international community which actors are considered international legal persons.
}

Low-lying States may be the innovators for the next sui generis forms or classes of international legal personality. These forms may be entirely new innovations, or adapted versions of cases such as those presented here. The precise forms of these new legal persons would be developed through negotiation with partner States and other international actors with which low-lying States wish to continue to engage on the international plane.

\section{Municipal Legal Personalities}

This part has so far focused on international legal personalities provided for in the Friendly Relations Declaration, that is, a sovereign and independent State, the free association or integration with an independent State, and various "other" State-like political statuses. In accordance with practice regarding internal self-determination, low-lying peoples might adopt a municipal legal personality within the jurisdiction of the partner State (municipal personality). This municipal personality might be in place of the

888 William Thomas Worster "Relative International Legal Personality of Non-State Actors" (2016) 42(2) Brook J Int'l L 207 at 221. 
current international personality that is statehood. Alternatively, a municipal personality might be additional and complementary to an international legal personality. With these two broad options, a municipal personality may enable internal self-determination, either with or without external self-determination. There is no literature exploring options for municipal personalities for low-lying States' ex situ arrangements. This gap exists despite the well-established possibility of internal self-determination, ${ }^{889}$ and the precedents offered by, in particular, indigenous peoples, some of which are explored in this section.

Whether or not a municipal personality complements an international personality, the importance of the former is its function of enabling the people's collective ownership and management (or 'governance') of communal (or 'public') assets in the territory of the partner State. These assets might include administration buildings, community hubs, health and education facilities, or, indeed, any infrastructure or services that might commonly be in public ownership and authority. Thus, where there is only a municipal legal personality, its functions would substitute - to an extent - those fulfilled today by the low-lying States.

The options considered here are trusts, corporations, incorporated societies, and sui generis entities. These all offer possibilities for collective decision-making, and collective ownership and management of assets. While the experiences of indigenous peoples are often dire, lessons may be learned from their use of these municipal personalities, which may provide low-lying peoples with some degree of autonomy for ex situ self-determination, albeit in an internal form.

\section{Trusts}

Trusts create relationships in which trustees hold property on behalf of, and with special obligations towards, beneficiaries. The trustees' obligations affect how the property can be managed insofar as this management must seek to be advantageous to the 
beneficiary. ${ }^{890}$ For supporting low-lying peoples' ex situ self-determination, it is possible that a trust could own assets and make investment decisions for the benefit of the beneficiaries (the low-lying people), including social and economic benefit. There are various means of promoting accountability of trustees, which might be constituted as a trust board or similar. Those accountability systems can resemble democratic decisionmaking and governance. For instance, the accountabilities of trust boards can be described in the terms of constitutive documents, such as a trust deed or a piece of legislation. ${ }^{891}$ The composition of trust boards can be the subject of elections. ${ }^{892}$ And trustees may be required to take advice or consult with beneficiaries or representatives of beneficiaries. ${ }^{893}$ Taken together, these elements of trusts offer apparatus relevant to the enjoyment of self-determination, particularly the substantive elements of economic, social and cultural development, and the procedural element of democratic decision-making.

An example of this option that specifically relates to peoples with the right to self-determination are the trusts used by Māori in New Zealand. As an indigenous people, Māori "have the right to self-determination [and] [b]y virtue of that right they freely determine their political status and freely pursue their economic social and cultural development", as UNDRIP states. ${ }^{894}$ One means by which internal self-determination is given effect is the use of trusts. Iwi (kinship groups or tribes) ${ }^{895}$ establish "settlement trusts" to settle claims regarding breaches of the Treaty of Waitangi ${ }^{896}$ by the Crown. ${ }^{897}$ Each settlement trust is unique to the particular historical circumstances and is established "to empower the various settlement groups to determine their own priorities". 898

890 Jessica Palmer "Theories of the Trust and What They Might Mean for Beneficiary Rights to Information" (2010) NZLR 541 at 542-543. See also New Zealand Law Commission Review of the Law of Trusts: A Trusts Act for New Zealand (Report 130, August 2013) at 2.2-2.3.

891 New Zealand Law Commission, above n 890, at 18 and 22.

892 See Māori Trust Boards Act 1955, ss 14(1) and 42-55A.

893 See ss 23A-23B.

894 UNDRIP, art 3.

895 Māori Dictionary "iwi" <www.maoridictionary.co.nz>.

896 Treaty of Waitangi 1840.

897 For example, Deed of Settlement of Historical Claims: Hineuru and the Trustees of te Kōpere o te Iwi o Hineuru Trust and the Crown (2015), cl 1.53-1.57.

898 New Zealand Law Commission Treaty of Waitangi Claims: Addressing the Post-Settlement Phase (NZLC SP13, 2002) at [17]. 
However, the general purposes include benefiting relevant iwi and hapū (a kinship group that is a sub-tribe of the iwi). ${ }^{899}$ For example, the Raukawa Settlement Trust states: ${ }^{900}$

The purposes for which the Trust is established are to receive, hold, manage and administer the Trust Fund for every purpose benefiting Raukawa whether it relates to the relief of poverty, the advancement of education, or any other matter beneficial to Raukawa and all the Members of Raukawa irrespective of where those Members reside.

The deed then sets out a series of "incidental purposes" of the Trust that give effect to the main purposes. These include developing social and economic advancement of Raukawa, making distributions of income to members, beneficiaries and representative collectives, receiving and holding assets including cash assets, and establishing and holding shares in companies. ${ }^{901}$ The trustees also exercise strategic governance of the entity and any respective asset holding companies and enterprises. ${ }^{902}$ This governance is relative to the trustees' stipulated powers, competencies and duties, as well as the oversight of the Kaunihere Kaumātua (Council of Elders). ${ }^{903}$ The governance is influenced also by the special relationship that the iwi has with the Crown (that is, the New Zealand government). The Raukawa Settlement Trust is recognised in legislation, the Raukawa Claims Settlement Act 2014, which has numerous provisions regarding the relationship between the Trust and the Crown. With respect to how the Trust is representative of the iwi, settlement trust deeds also set out rules regarding the appointment and removal of trustees. ${ }^{904}$

Many elements of the settlement trust resemble the functional aspects seen in other trust forms, such as charitable or family trusts. However, Māori settlement trusts contain elements important to indigenous identities and tikanga (the Māori system of values and practices, including protocols and customs). ${ }^{905}$ The deeds contain a historical account,

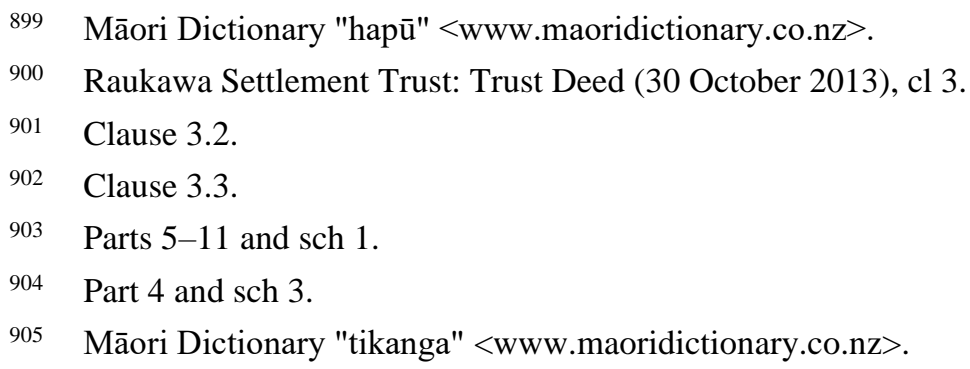


acknowledgements of wrongdoing by the Crown (including an apology, settlement, cultural redress, financial and commercial redress), and a requirement that the Crown must propose settlement legislation that is supported by the iwi and trustees.

Since a central element of the settlement trust model is to protect tikanga Māori, it is potentially relevant to low-lying peoples seeking self-determination and the protection of their ways of life, te katei ni Kiribati and tuи mo aganu Tuvalu, for instance. Many of the elements of the settlement trust reflect a meaningful degree of social, cultural and economic autonomy, plus a special statutory relationship with the State. Each of the Māori settlement trusts differ and would, therefore, provide a wealth of ideas for how this model might be adopted and used by the peoples of low-lying States. ${ }^{906}$

There are important weaknesses in this model. As a municipal mechanism, Māori trusts are ultimately subservient to the New Zealand Parliament and the two parties, Māori and the Crown, are not equals in terms of authority. However, the Treaty of Waitangi, which is a central legal force underpinning settlements with Māori trusts, is a constitutional document and Parliament's powers with respect to Māori are not untrammelled. ${ }^{907}$ A second limitation of the Māori trust model is that the legal challenges are just one part of a much deeper set of challenges that have persisted since colonisation. The lessons from that history might also provide useful insights for low-lying islanders experiencing "inverse colonisation", but that is beyond the scope of this thesis.

Overall, and as is the case with all the municipal legal personalities, the rights and privileges that low-lying peoples enjoy today within their homelands would be limited in a trust model. However, it does have functions that are consistent with the essential elements of self-determination. 


\section{Corporations}

Corporations are another legal personality that can be used for collective decisionmaking and collective ownership of assets. Although normally considered in relation to for-profit enterprises, there are alternative uses that may be attractive to the peoples of low-lying States. In Australia, the Indigenous Land Corporation exists to assist Aboriginal persons and Torres Strait Islander persons acquire and manage land and, thereby, provide economic, social and cultural benefits. ${ }^{908}$ Complementary to this is the Aboriginal and Torres Strait Islander Land Account, which establishes a perpetual fund to support the Corporation's land acquisition and management functions. ${ }^{909}$ The Corporation is government-owned but there must be at least five indigenous members of the seven-person Board.

Another case study is of Alaska's Native corporations. Twelve Native Associations, 12 associated Regional Corporations, and a further 203 Village Corporations were established through the Alaska Native Claims Settlement Act of 1971.910 The corporations are variously for-profit and not-for-profit, ${ }^{911}$ and the Act sets out details regarding these organisations' governance and purposes. The decades of experience that the Alaska Native peoples have with this model highlight some of the problems. In particular, the Alaska Natives have found the model to be economically-oriented at the expense of a people's cultural basis. ${ }^{912}$ It has also compelled Alaska Natives to adopt the behaviours acceptable to state and federal governments at the expense of how they think of, and relate amongst, themselves. ${ }^{913}$ Manual (4th ed, Alaska Society of Professional Land Surveyors, 2013) Chapter 3, at 2, referring to Alaska Native Claims Settlement Act, Public Law 92.203 (1971) (AK, US), arts 7(a), 7(d) and 8(a).

911 Alaska Native Claims Settlement Act, Public Law 92.203 (1971), art 8(a)

912 Mason Durie Te Mana, Te Kawanatanga: The Politics of Māori Self-Determination (Oxford University Press, Oxford, 1998) at 226-227.

913 Thomas Michael Swensen "Of Subjection and Sovereignty: Alaska Native Corporations and Tribal Governments in the Twenty-First Century" (2015) 30(1) Wicazo Sa Review 100 at 101. 
Adhering to corporate and government models, systems and processes that differ markedly from a people's own way of life is a risk to a substantive element of self-determination, which is to freely determine cultural development. ${ }^{914}$ If such risks can be addressed in the design of corporations, this model may be a mechanism for low-lying peoples to collectively own and manage assets that support their economic, social and cultural development as part of their internal self-determination within a partner State's jurisdiction.

\section{Incorporated societies}

Societies may be incorporated or unincorporated, which means that they may or may not have a legal personality. In the case of New Zealand incorporated societies, these are not-for-profit, membership-based organisations that must have rules regarding their objectives and modus operandi, and which may hold assets and liabilities, ${ }^{915}$ enter contracts, and otherwise run their affairs as if they were individuals. ${ }^{916}$ Like corporations, incorporated societies enjoy perpetuity even where members change, and members are not personally liable for the society's obligations. That said, unlike corporations, all members are liable for a society's obligations if they were incurred for pecuniary gain. ${ }^{917}$ Incorporated societies are often used by the likes of "sports clubs, social clubs, music and cultural groups, special interest and activist organisations". ${ }^{918}$ For the peoples of low-lying States, the personal liability of members would be a challenge to using a society for economic development. However, societies could, if appropriately designed, be a vehicle for collective activities and asset ownership.

\footnotetext{
914 Chapter 2, Part VII(A)(4).

915 Incorporated Societies Act 1908 (NZ), ss 4(1), 6 and 23(1).

916 Companies Office (NZ) "What is an incorporated society?" <www.societies.govt.nz>.

917 Companies Office (NZ) "What are the advantages of becoming an incorporated society?" <www.societies.govt.nz>.

918 Companies Office, above n 916.
} 


\section{4. $\quad$ Sui Generis Juridical Entities}

In addition to these orthodox forms of municipal legal personality, new legal persons can be created. For instance, a river (the Ganges) was made a legal person in India through common law court decision ${ }^{919}$ and another river (the Whanganui River) was made a legal person in New Zealand by legislation. ${ }^{920}$ These examples are not directly transferable, since low-lying States and their peoples are already legal persons. However, it illustrates the degree of innovation that is possible: something entirely new and bespoke could be devised to support the low-lying peoples' relocation enterprises and ex situ self-determination.

\section{Concluding on Municipal Legal Personalities}

It is submitted that, if a municipal personality is adopted, the suitability of the type chosen should be measured against its ability to secure a degree of autonomy necessary for the low-lying people's enjoyment of self-determination. To this end, it is not only about the form of legal person. Important to the choice of personality, or personalities, is the entity's independence relative to the potential for intervention by the partner State, its purposes, and its governance methodologies, powers and responsibilities. ${ }^{921}$ The membership, the leadership's accountabilities, the membership's liabilities, and how the people participate in the entity's decision-making are other important considerations. So too are how the entity's incomes are generated and distributed, and how it acquires, uses and disposes of assets. Overall, the entity's suitability will be determined by how all of those and other features collectively enable the people's autonomy and identity.

Mohd Salim v State of Uttarakhand \& others [2017] WPPIL 126/2014 (High Court of Uttarakhand, India) at [19].

920 Te Awa Tupua (Whanganui River Claims Settlement) Act 2017 (NZ), s 14.

921 See Submission of the Māori Land Court Judges to the Māori Affairs Select Committee on Te Ture Whenua Māori Amendment Bill 1999 at 13, cited in Law Commission, above n 898, at v. 


\section{E. No Legal Personality}

It is useful to consider, for the purposes of completeness and as a counterfactual to the options, the potential of having no legal personality in terms of what it may offer towards the enjoyment of self-determination. This chapter has avoided recommending for or against any of the options presented, as it is for the people to self-determine what path they wish to take. However, it is submitted that relying on this option of no legal personality would fail to protect low-lying peoples' self-determination.

A useful description of the advantages and disadvantages of unincorporated groups comes from the Community Law Centres o Aotearoa. ${ }^{922}$ The advantages include: avoiding the incorporation process; having fewer ongoing administrative requirements and costs; and retaining flexibility with regards to the structure and operation of the group.

The disadvantages of unincorporated groups are: the lack of separate legal identity, meaning the organisation has no legal standing and no perpetual existence; the personal liability of members; the uncertainty regarding rules and rights, which may create problems with dispute resolution; and uncertainties surrounding membership, including identifying members and their rights and obligations regarding the group.

Some degree of autonomy is essential for a self-determining people to freely determine, inter alia, their economic, social and cultural development. ${ }^{923}$ Enjoying this autonomy also requires a juridical entity that has standing to bring an action against the partner State or another party that it believes has infringed upon its entitlements. The lack of standing, along with the other disadvantages, relegate unincorporated entities to something akin to a social group. It is a significant departure from the bundle of rights that comprise self-determination ${ }^{924}$ and, therefore, points more towards the problem definition in chapter 1 than the solutions, which are the focus of this chapter. Without

\footnotetext{
922 Community Law Centres o Aotearoa "Choosing the right legal structure for your group" Community Law <www.communitylaw.org.nz>.

923 Chapter 2, Part VII(B)(3).

924 Chapter 2, Part VII.
} 
considerable governmental support, an unincorporated society would only attract minority rights for its members, not self-determination.

\section{F. Concluding on Forms of Legal Person}

There is a range of existing forms of legal personality that low-lying States could choose to support their peoples' enjoyment of self-determination, with varying powers and rights. The low-lying State might maintain statehood or adopt an alternative international legal personality, or it may establish a municipal legal personality in a partner State's jurisdiction. In fact, there may be multiple legal personalities. For instance, there may be one on the international plane, plus one or more municipal legal personalities for different functions. Furthermore, it is also apparent from the evolution of juridical persons over time that further development is possible. The international and municipal sui generis entities show that something bespoke can be invented by the relevant parties to meet their requirements.

\section{Land: Modes of Acquiring Land as Territory or Property}

In addition to the different forms of legal personality discussed in the previous part, another key issue for enjoying self-determination ex situ is land. This section focuses on options for low-lying peoples obtaining land in the partner State's territory, including whether it is held as territory or property, and how that land is acquired, that is, whether it is ceded, shared as a condominium, purchased, or leased. In this analysis, "territory" is used in the sense defined in Black's Law Dictionary: that is, a "geographical area included within a particular government's jurisdiction; the portion of the earth's surface that is in a State's exclusive possession and control."925 "Property" is used as relating to real property, that is, "[1] and and anything growing on or attached to, or erected on it". ${ }^{926}$ To put it simply, only States can have territory; other legal persons cannot. A range of legal persons may hold real property, including States, natural legal persons, trusts and corporations.

925 Garner, above n 148, at 1701.

926 At 1412. 
This part also looks at how land may be geographically arranged and distributed, plus related issues stemming from the free movement of individuals.

\section{A. Cession}

Cession of territory involves the transfer of sovereignty and "complete surrender of jurisdiction"927 over territory, that is, the "rectification of frontiers", ${ }^{928}$ via bilateral agreement. ${ }^{929}$ It is theoretically feasible that a partner State could cede territory to a low-lying State as a means to enable the latter's relocation enterprise. For example, Tuvalu made an official request to Australia for a parcel of territory for the former's relocation in $2008 .^{930}$ The cession of territory by a partner State to a low-lying State would provide the clearest means of enabling ex situ statehood ${ }^{931}$ and self-determination.

Yamamoto and Esteban note a wide range of cession precedents, including the sale of Louisiana by France to the United States, and the granting of land by Canada to Icelandic people displaced by a volcanic eruption. They also examine the cases of the Boers and the Banabans, which did not involve cession, but were reasonably comparable circumstances. ${ }^{932}$

Although feasible, cession is commonly presumed to be a politically-unlikely option for partner States. ${ }^{933}$ Willcox challenges these orthodox views by highlighting a

$$
\text { Displi } 2014
$$
Displacement Solutions Climate Change, Displaced Persons and Housing, Land and Property Rights: Preliminary Strategies for Rights-Based Planning and Programming to Resolve Climate-Induced Displacement (Displacement Solutions, Geneva) at 20.

931 Rayfuse, above n 92, at 284.

932 Yamamoto and Esteban, above n 648, at 187-197.

DL Corbitt "What is Liberal Cession of Western Territory?" (1926) 3(2) North Carolina Historical Review 372 at 372.

Burgard v Mair (1916) Tribunal Civil de Saint Etienne, 7 June 1916, reported 1917, as summarised in "Current Decisions" (1918) XXVII(4) Yale L J 574 at 577.

( Oxford) at "cession"; and Yamamoto and Esteban, above n 648, at 187. (2014) 12 International Law Readings (Voronezh State University) 140 at 153-154, citing

\footnotetext{
933 For example, McAdam, above n 41, at 147; and Rayfuse, above n 92, at 284-285.
} 
number of reasons in favour of this option. ${ }^{934}$ First, cession "could be considered as an attempt to protect, rather than subvert, principles of territorial integrity and state sovereignty and, as a consequence, international peace and security." ${ }^{935}$ Secondly, cession would avoid any risks of "dilution of the autonomy or shared way of life of a receiving people" since low-lying peoples reside in an area carved out from the partner State's territory. ${ }^{936}$ Willcox suggests that this approach may actually be less burdensome on destination communities. Thirdly, the destination States' costs, in terms of land, infrastructure and governance, would be lower than integrating a relatively large number of climate migrants. ${ }^{937}$ This would hold true especially for supporting those climate migrants who are unable to work due to age or disability, for instance, and thus require government social security support.

While Willcox makes an interesting case, there are still considerable policy challenges for a partner State considering ceding territory and, for countries like Fiji, New Zealand and Australia, sharing a border for the first time. These challenges might be limited if the land ceded were very small - perhaps just enough to be home to a "population nucleus", 938 such as the Vatican's 0.44 square kilometres - or perhaps on an island, which limits the burden of the boundary issue. ${ }^{939}$

\section{B. Condominium: Shared Sovereignty}

One alternative to ceded territory is a condominium, that is, joint dominion and shared sovereignty, over a parcel of the partner State's territory. ${ }^{940}$ Generally, a condominium is where "two or more states equally [or unequally] ${ }^{941}$ exercise sovereignty

\footnotetext{
934 Willcox, above n 162, at 162-171.

935 At 162.

936 At 163.

937 At 164.

938 Stoutenburg, above n 127, at 65.

939 Yamamoto and Esteban, above n 648, at 189.

940 DP O'Connell "The Condominium of the New Hebrides" in Humphrey Waldock and RY Jennings (eds) British Yearbook of International Law 1968-69 (Oxford University Press, London, 1970) 71 at 81 ; and Shearer, above n 570, at 105.
}

941 O'Connell, above n 940, at 78. 
with respect to a territory and its inhabitants"942 via arrangements defined in a bilateral or plurilateral treaty. ${ }^{943}$ There are complications as to the exact definition of condominia, such as whether sovereignty is shared or joint but coexisting, and whether, or to what extent, the States' jurisdictions are shared or divided. ${ }^{944}$ Such complications led O'Connell to conclude that "the concept of the Condominium is unstable and incongruous, and that each regime of joint supremacy is sui generis." 945 The bespoke nature of these arrangements perhaps reflects the fact that "States with rival claims to territory have attempted to solve their differences by the expedient of joint rule". ${ }^{946}$

One example of how parties shared authority was the New Hebrides Condominium. This evolved through competing and shared interests of France and Britain that led to a Joint Naval Commission in 1887, followed by the Condominium itself, established through a 1906 Convention, followed further by a Protocol in 1914 which amended the Convention. ${ }^{947}$ Key elements of the Condominium included: $: 448$

- British and French subjects "would enjoy equal rights of residence, personal protection and trade"; 949

- Britain and France each retained sovereignty over their own nationals and corporations, but established "a judicial system to deal with matters that would not fall within either national jurisdiction"; 950

- Neither Britain nor France would exercise separate control over the New Hebrides;

942 Shaw, above n 91, at 165; and see Abdalla Ali El-Erian Condominium and Related Situations in International Law: with special reference to the dual administration of the Sudan and the legal problems arising out of it (Fouad I University Press, Cairo, 1951) at 99.

943 O'Connell, above $\mathrm{n} 940$, at 83.

944 At $78-79$ and 81.

945 At 81 .

946 At 71.

947 At 71-76.

948 At 92.

949 At 92.

950 At 76 . 
- High Commissioners of each country operated under the principles of, first, equality of government by the two States and, secondly, coexistence of their respective jurisdictions; and

- Some functions were committed to the two High Commissioners jointly and thereby became Condominium functions, including public works, ports and harbours, public health, and finance administration.

In this arrangement, there were effectively three Governments involved: the British, the French, and the Condominium itself, ${ }^{951}$ which ultimately became a person at international law capable of entering into treaties. ${ }^{952}$

The New Hebrides Condominium ceased and was replaced by the independent Republic of Vanuatu in $1980 .{ }^{953}$ This was a result of Ni-Vanuatu's frustrations over increasing French and British land ownership, and a desire for independence from those colonial powers. ${ }^{954}$ There were concerns that the condominium system had created excessive bureaucracy and legal duplication, leading some to describe it as a "pandemonium". 955

A condominium arrangement offers the possibility of low-lying States having territory ex situ, but without the partner State having to cede it. The New Hebrides example, along with the fact that condominia are all sui generis entities, illustrates how particular circumstances can give rise to unique systems. It seems likely that disputes will arise, so a bilateral agreement should incorporate transparent dispute resolution systems and processes for amending the agreement.

\footnotetext{
951 Shaw, above n 91, at 166.

952 O'Connell, above n 940, at 88.

953 Marc Lanteigne "Vanuatu" in Levine, above n 346, 361 at 362.

954 At 362.

955 At 362.
} 


\section{Property, not Territory}

Rather than territory, low-lying States' populations could reside on property acquired through grant, purchase, or lease. This could be held as mainstream freehold land, perhaps under special conditions, as in the case of the Order of Malta's properties, or have a special title, as in the case of New Zealand's "Māori freehold land".

The Order of Malta is an international legal person but lacks sovereign territory. ${ }^{956}$ It owns properties in Italy and Malta under special conditions. For example, the property in Malta is subject to an agreement that regulates the relations between the Order and the Republic of Malta. Malta has agreed to ensure supply of public services to the Order with preferential rates of tariffs. ${ }^{957}$ It has agreed to the Order's inviolability and immunity from search or other interference, ${ }^{958}$ and that the Order is exempt from a range of taxes and levies. ${ }^{959}$

New Zealand's "Māori freehold land" is one of number of land statuses. ${ }^{960}$ It is land that was customary land prior to colonisation and its beneficial ownership by Māori has been confirmed by the Māori Land Court. ${ }^{961}$ It may be held by individual interests or group interests, such as the trusts discussed earlier. ${ }^{962}$ As the land can be held by groups with potential for disputes among group members, legislation (Te Ture Whenua Māori Act 1993) regulates the powers of "assembled owners", how multiple owners may be represented, the alienation of land, the proceeds of alienation, how Māori freehold land may be leased, and how it is owned and governed relative to Māori trusts, among other

956 Noel Cox "The Continuing Question of Sovereignty and the Sovereign Military Order of Jerusalem, of Rhodes and of Malta" (2006) 13 Aust ILJ 211 at 218, n 38.

957 Agreement between the Government of Malta and the Government of the Sovereign Military Hospitaller Order of St John of Jerusalem, of Rhodes and of Malta (signed 5 December 1998), art 3(4)-(5).

958 Article 3(2)-(3).

959 Article 7(4).

960 Te Ture Whenua Māori Act 1993, s 129(1).

961 Sections 129(2) and 132-134.

962 This Chapter, Part II(D)(1). 
things. ${ }^{963}$ The special model of group ownership is informative for low-lying peoples' ex situ re-establishment, particularly for the Pacific low-lying States where as much as 80 per cent of land is held by collectives under customary title. ${ }^{964}$

These case studies illustrate the potential for low-lying States to establish themselves on property in a partner State's territory held under special terms that respect their unique circumstances. While the rights and privileges that come with these property tenures are limited compared to sovereign territory, it is possible to have rights and privileges that are beyond those that would be enjoyed with simple freehold land in order to support ex situ self-determination.

\section{Purchase}

Both territory and property can be acquired through purchase. For instance, in 1803, France sold and ceded the territory of Louisiana to the United States through a bilateral treaty $^{965}$ for consideration of 80 million francs (15 million US dollars). ${ }^{966}$ Some of the low-lying States are already looking at property purchases. For example, Kiribati has purchased land in Fiji, ${ }^{967}$ the Maldives is beginning to work on land purchases in Sri Lanka and India, ${ }^{968}$ and Tuvalu is considering land purchases in Australia and New Zealand. ${ }^{969}$ Dalila Gharbaoui and Julia Blocher "The Reason Land Matters: Relocation as Adaptation to Climate Change in Fiji Islands" in Andrea Milan and others (eds) Migration, Risk Management and Climate Change: Evidence and Policy Responses (Springer, Heidelberg, 2017) 149 at 156-158.

965

Te Ture Whenua Māori Act, pts 7 and 8.

Treaty between the United States of America and the French Republic (Louisiana Purchase Treaty), 30 April 1803, in particular, articles I-III.

Rachel Eden Black "Barbé-Marbois, François, Marquis de" in Junius P Rodriguez (ed) The Louisiana Purchase: A Historical and Geographic Encyclopedia (ABC-Clio, Santa Barbara, 2002) 24 at 25.

Ellsmoor and Rosen, above n 463.

Randeep Ramesh "Paradise almost lost: Maldives seek to buy a new homeland" The Guardian (online ed, London, 10 November 2008).

Radio New Zealand, above n 478. 


\section{E. International and Quasi-international Leases}

An alternative to purchase is to obtain land via an international lease, that is, a lease made in a bilateral treaty. In an international lease regarding a parcel of territory, sovereignty over that territory is treated as having passed to the lessee State - in this case, the low-lying State - during the period of the lease, but ultimate ownership and sovereignty remains with the lessor State - in this case, the destination State. ${ }^{970}$

An informative exemplar of an international lease is that between the United States and Cuba regarding the 116 square kilometre Cuban territory, Guantánamo Bay. As the United States Supreme Court has explained when considering which State held sovereignty over Guantánamo Bay: ${ }^{971}$

\footnotetext{
... under the terms of the lease between the United States and Cuba, Cuba retains 'ultimate sovereignty' over the territory while the United States exercises 'complete jurisdiction and control.' ... Under the terms of the 1934 Treaty, however, Cuba effectively has no rights as a sovereign until the parties agree to modification of the 1903 Lease Agreement or the United States abandons the base....
}

Indeed, it is not altogether uncommon for a territory to be under the de jure sovereignty of one nation, while under the plenary control, or practical sovereignty, of another.

The lease relates not only to land territory but also "the right to use and occupy the waters adjacent" in any fashion "necessary to fit the premises for use as coaling or naval stations only, and for no other purpose". ${ }^{972}$

The duration of such leases is entirely flexible. For example, the agreement between the United States and Cuba for the lease of Guantanamo Bay says the period of the lease

\footnotetext{
970 Shaw, above n 91, at 389.

971 Boumediene v Bush 553 US 723 (2009) at 23-24, referring to Treaty Defining Relations with Cuba, United States-Cuba 48 Stat 1683, TS 866 (29 May 1934), art III; and Agreement Between the United States and Cuba for the Lease of Lands for Coaling and Naval stations (23 February 1903) [Guantánamo Bay Lease Agreement].

972 Guantanamo Bay Lease Agreement, art 2.
} 
is "for the time required for the purposes of coaling and naval stations", 973 and it is unlikely the United States will have no use for the naval station any time soon. By comparison, the United Kingdom leased the territory of Hong Kong from China for a finite period; 99 years, from 1898 to $1997 .{ }^{974}$

For the low-lying States' purposes, these examples show that leases may be entered into via a treaty in international law, and they can transfer far-reaching authority, for lengthy and even indefinite periods of time. Such leases, therefore, have the potential to offer the low-lying States a high degree of security over land and maritime territory without the partner State having to trigger the options for cession or sale, which may be hindered by wider political implications.

\section{F. A Note on Geographic Arrangements: Enclaves and Exclaves}

For the options regarding land, existing models of enclaves and exclaves may be helpful for imagining how they may appear and function geographically. Enclaves are landlocked States that are surrounded completely by the territory of a single foreign State. Lesotho is surrounded by South Africa, San Marino is surrounded by Italy, and the Vatican City (if it is accepted as a State) is within Italy. There are also subnational enclaves, in which a governmental entity's jurisdiction is surrounded by another entity's jurisdiction, such as the Australian Capital Territory being surrounded by the state of New South Wales.

An exclave, by contrast, is part of the territory of a State that is separated from the main territory by a foreign territory. For example, the Spanish town of Llívia, which has a population of around 1,500, is separated from mainland Spain as an enclave within France. ${ }^{975}$ Similarly, Büsingen am Hochrhein is an exclave of Germany, which is

973 Art 1; and see Treaty Defining Relations with Cuba, art III.

974 Convention between the United Kingdom and China respecting an extension of Hong Kong territory (signed 9 June 1898, entered into force 6 August 1898).

975 Laure Fourquet "This Catalan Town Has Already Broken From Spain, Physically at Least" The New York Times (online ed, New York, 24 October 2017). 
surrounded by Switzerland, and which has a population of $1,355 .{ }^{976}$ In that case, while German law applies generally within the municipality, there is a treaty between Germany and Switzerland which provides that Büsingen is part of the Swiss customs territory. ${ }^{977}$ In each case, sovereignty is exercised from afar, from mainland Spain and Germany, even where the outlying territories are very small, have very small populations, and are surrounded entirely by other sovereign States.

Should a low-lying State secure land for its people's relocation, that land may be surrounded by the territory of the partner State. Furthermore, this land may be considered an exclave from the primary atolls, islands and maritime zones of low-lying States, even if those are uninhabitable due to the effects of climate change. While the geography may be vast and dispersed, some low-lying States already function over such distances. In particular, the atolls and islands of Kiribati are spread across 3.5 million square kilometres, and nine atolls have no population. ${ }^{978}$ Furthermore, the I-Kiribati territories are in three groups of atolls that are in three non-contiguous exclusive economic zones: the Gilbert Group, the Phoenix Group and the Line Group. ${ }^{979}$

Overall, enclaves and exclaves show that low-lying States might practice sovereignty over land surrounded by a partner State, and may extend that sovereignty over their current territories from a seat of government in another State's territory.

\section{G. Will People Stay Together? Liberty of Movement and Diasporic Cosmopolitanism}

As well as concerns regarding the geographical distribution of the legal person, another practical matter is the distribution of the peoples. In cross-border migration

\footnotetext{
976 Büsingen am Hochrhein "Local Portrait" <www.buesingen.de>.

977 Büsingen am Hochrhein "State Treaty: Germany - Switzerland via Büsingen" <www.buesingen.de>.

978 The 2015 census includes population by island data, and the population figures for the 24 atolls and islands listed equal the total population of Kiribati, even though the country has 33 atolls and islands, so 9 atolls must have no population or no recorded population: National Statistics Office (KI), above n 182 , at 31 .

979 Exclusive Economic Zone Outer Limit Regulations 2014 (KI), sch 4. New Zealand also has noncontiguous exclusive economic zones pertaining to the Realm of New Zealand, such as around Tokelau: Tokelau (Territorial Sea and Exclusive Economic Zone) Act 1977 (NZ).
} 
scenarios, there are multiple reasons why low-lying peoples will be fragmented, including movement being gradual and piecemeal, as well as individuals' choices of countries and regions being influenced by such things as eligibility to reside in potential destination States, and where family and friends have already emigrated. Even in a highly unlikely scenario where a whole low-lying people move to a single destination State, individuals will still enjoy the right to freedom of movement within that country. Fragmentation is at the heart of the risks to self-determination, as detailed in chapter $1 .{ }^{980}$ However, the risks may be ameliorated partially through systems for supporting diasporic cosmopolitanism.

Cosmopolitanism is, as Burkett explains, "the belief that all human beings, irrespective of State affiliations or political boundaries, belong to a single global community that should be acknowledged and cultivated." 981 According to McKinley, "the cosmopolitan claim [is] that shared identities and human solidarities are no longer conterminous with territorial delimitations". ${ }^{982}$ Even so, "the relationship among people, place/territory and identity is one that is critical for contemporary cosmopolitan citizenship". ${ }^{983}$ Therefore, "neither diasporic nor transmigrant communities relinquish substantive citizenship in their birth counties, although their dispersed residence and loyalties disrupt the neat correlation between citizenship and residence."984

If low-lying States establish cosmopolitan membership for their diaspora, members' places of residence would become less relevant and the risks associated with fragmentation would be partially mitigated. For example, it may be that the government and administration of a low-lying State, and perhaps many of its citizens, relocate to Region 1 within Country A, while other citizens migrate to Regions 2 or 3, or Countries B or C. Those citizens living afar can remain part of the cosmopolitan State and, for

\footnotetext{
980 See also Chapter 3, Parts II(B)(3) and IV.

981 Burkett, above n 779, at 99 (citations omitted).

982 Michelle A McKinley "Conviviality, Cosmopolitan Citizenship, and Hospitality" (2009) 5 Unbound 55 at 60.

983 At 83.

984 At 83.
} 
instance, take part in elections from outside Region 1, Country A. Already, many States provide for voting in national elections from abroad, including the Marshall Islands. ${ }^{985}$

Diasporic cosmopolitanism could be supported by internet-based connectivity among members. Although one ought to err on the side of caution in relying on the internet to maintain community connection, there is clearly a potential role for online tools. Diamandaki has identified certain nations without States, which have created online communities: "the Jews, the Kurds, the Assyrians, the Palestinians, and the Tibetans." 986 Regarding Jewish communities online, Tannenbaum explains: ${ }^{987}$

\footnotetext{
For those of us already living in Jewish communities, the Internet binds us together. We can get information, we chat on mailing lists, and we can share our ideas and personalities on web sites. But for Jews isolated in remote locations, the web can really open up the Jewish world for them. And as time goes by, the web will bring us more and more to learn about our people, Jewish history and culture, and torah and mitzvoth.
}

Rosencrance clearly overestimated the potential for online communities when he proclaimed in 1996 that "territory becomes passé" in "the rise of the virtual State".988 Nevertheless, the internet offers a range of existing and potential tools for maintaining connectivity among diaspora of low-lying States to one another and to the central government and administration. Those tools can complement constitutional apparatus, such as laws enabling voting from abroad.

\section{H. Issues with Acquiring Land}

Irrespective of its legal classification or the method of acquisition, and despite the potential for geographical and population distributions to be managed, land will remain (2003) 2(2) Global Media Journal 1 at 7.

987 World Union of Jewish Students "The Jewish Internet - A Guru's View" <www.wujs.org.il>, as cited in Diamandaki, above n 986, at 7.

988 Richard Rosencrance "The Rise of the Virtual State" (1996) 75 Foreign Affairs 45 at 45. 
one of the most challenging practical elements in relocating a people. ${ }^{989}$ One issue is that "customary lands make up the majority of lands in most Pacific island countries", 990 which creates complexities around its availability and how relocation may be facilitated. ${ }^{991}$

Another challenge, which may be related to the issue of land availability, is the potential for conflict between previously-settled locals and relocating communities. ${ }^{992}$ For example, the Government of Kiribati purchased all but 125ha of the 2,331ha Natoavatu Estate in Fiji from the Anglican Church. The Church had purchased the land for use by the 270 remaining descendants of emancipated Solomon Islander slaves, who will reside in the remaining $125 \mathrm{ha}$. Those people argue that they use 283 ha to feed themselves. There are, therefore, preconditions for social friction and disputes before I-Kiribati begin to make use of the land.

These two issues, customary land and potential for dispute, illustrate the complexities involved with land acquisition. Further research is required to examine the nexus between climate migration, land, traditional knowledge, conflict-prevention, and how development outcomes are progressed or prevented from reversing in relocation enterprises.

\section{International Frameworks for Enabling Ex Situ Self-Determination}

The UN Charter, the 1966 human rights Covenants, plus many other international instruments, declarations and judicial decisions provide for all peoples' right to

989 Dhrishna Charan, Manpreet Kaur and Priyatma Singh "Customary Land and Climate Change Induced Relocation-A Case Study of Vunidogoloa Village, Vanua Levu, Fiji" in Walter Leal Filho (ed) Climate Change Adaptation in Pacific Countries: Fostering Resilience and Improving Quality of Life (Springer, Heidelberg, 2017) 19 at 19-20;

990 Iata Iata "Customary Land Rights and Pacific Islands Security \& Stability" (2018) 419 Asia Pacific Bulletin 1 at 1; and see Gharbaoui and Blocher, above n 964, at 157.

991 Gharbaoui and Blocher, above n 964.

992 Ellsmoor and Rosen, above n 463; and Christopher Pala "Kiribati President Purchases 'Worthless' Resettlement Land as Precaution Against Rising Sea" (9 June 2014) Inter Press Service <www.ipsnews.net>. 
self-determination. ${ }^{993}$ However, some form of international instrument or initiative will be required to address the unprecedented nature of attempting to preserve that right in the territory of another State. This part sets out the classes of international instruments and initiatives that may be employed for this purpose. It also discusses, at a high level, their potential relative to the low-lying peoples' ex situ self-determination. The classes are: multilateral treaties; international soft law instruments, including voluntary cooperation initiatives; regional programmes; and bilateral regimes. Bilateral treaties have the most potential for securing legal personality and land, along with specific matters addressing the substantive and procedural aspects of self-determination. However, it may be that more than one class of instrument or initiative will be required: in seeking ex situ self-determination, different issues may be better served, or more realistically negotiated, in separate instruments and initiatives.

An important preface for discussing classes of binding instrument is that, under art 53 of the VCLT, "[a] treaty is void if, at the time of its conclusion, it conflicts with a peremptory norm of general international law", and it is widely accepted that the right to self-determination may be one such norm. ${ }^{994}$ Even if that is incorrect, the UN General Assembly has also determined that treaties that conflict with self-determination are invalid. ${ }^{995}$ Furthermore, according to the OHCHR, States have extraterritorial obligations in international law towards other States and towards individuals, ${ }^{996}$ which include "[e]nsur[ing] human rights are given due attention in international agreements and that such agreements do not adversely impact upon human rights." ${ }^{997}$ In sum, any binding agreement regarding low-lying peoples' climate change-related migration cannot conflict with the right to self-determination. Nevertheless, there is wide room for interpretation by potential partner and destination States in determining how self-determination is respected. Therefore, a challenge for low-lying peoples will be finding the right combination of rights and duties, in the right combination of instruments and initiatives

\footnotetext{
Chapter 2, Part V.

Chapter 2, Part V.

Question of Palestine GA Res 34/65 (1979) at B[2]-[4]; and see Tladi, above n 255, at [31].

OHCHR, above n 302, at [87].

OHCHR, above n 302, at [86].
} 
that have the effect of creating a modus vivendi; that is, an agreement allowing them to coexist with the partner State while protecting their way of life. ${ }^{998}$

\section{A. Multilateral Agreements}

The current multilateral treaty regime regarding migration does not adequately cover climate change-related movement. ${ }^{999}$ Importantly, the Refugee Convention is inapplicable. ${ }^{1000}$ Also, the international migration regime does not seek to protect self-determination in situations of en masse relocation. The phrase "self-determination" is absent from all relevant binding agreements: the Refugee Convention; the International Convention on the Protection of the Rights of All Migrant Workers and Members of Their Families; ${ }^{1001}$ the Convention Relating to the Status of Stateless Persons; ${ }^{1002}$ and the African Union Convention for the Protection and Assistance of Internally Displaced Persons in Africa (Kampala Convention). ${ }^{1003}$ Self-determination is also not referred to in relevant non-binding multilateral outcomes; the New York Declaration, ${ }^{1004}$ the Global Compact for Migration, ${ }^{1005}$ and the Global Compact on Refugees. ${ }^{1006}$

International migration policies follow 'bottom-up' national priorities that are closely associated with sovereignty questions, so they remain inadequate for climate

998 For example, "Kosovo's external security depends critically on patiently establishing a modus vivendi with the Serbian state.": The Kosovo Report, above n 168, at 276.

999 Jane McAdam "Environmental Migration Governance" (2009) UNSW Law Research Paper 2009-1 at 1 .

1000 AF (Kiribati), above n 96; Teitiota v Chief Executive of MBIE, above n 96; and see Chapter 1, Part $\mathrm{IV}(\mathrm{A})$.

1001 Convention on Migrant Workers, above n 304.

1002 Convention Relating to the Status of Stateless Persons 360 UNTS 117 (opened for signature 28 September 1954, entered into force 6 June 1960).

1003 African Union Convention for the Protection and Assistance of Internally Displaced Persons in Africa (Kampala Convention) (opened for signature 22 October 2009, entered into force 6 December 2012).

1004 New York Declaration, above n 83.

1005 Global Compact for Migration, above n 66.

1006 Global Compact on Refugees A/73/12 (Part II) (2018) at I(A)(4). On the endorsement of the Global Compact on Refugees, see General Assembly Seventy-Third Session: 55th plenary meeting, Monday 17 December 2018 (2018) A/73/PV.55 at 8-12. 
change-related migration. ${ }^{1007}$ Nevertheless, some commentators consider that a new international mechanism or changes to existing mechanisms is needed to address the current regime's limitations. The Refugee Convention could, for instance, be amended to cover persons displaced by climate change. The concept of an "environmental refugee" was proposed by El-Hinnawi for the UN Environment Program (UNEP) in 1985, which he defined as: ${ }^{1008}$

... those people who have been forced to leave their traditional habitat, temporarily or permanently, because of a marked environmental disruption (natural and/or triggered by people) that jeopardized their existence and/or seriously affected the quality of their life. By 'environmental disruption' in this definition is meant any physical, chemical, and/or biological changes in the ecosystem (or resource base) that render it, temporarily or permanently, unsuitable to support human life.

There are problems with this definition, particularly regarding the requisite causation, since migration is driven by many factors. ${ }^{1009}$ Recognising these limits, Falstrom proposes a Convention on the Protection of Environmentally Displaced Persons. ${ }^{1010}$ Similarly, Bierman and Boas "argue for a sui generis regime for the recognition, protection, and resettlement of climate refugees". ${ }^{1011}$ Amending the current Refugee Convention, they argue, would be inadequate because "[m]ost climate refugees will not leave their home countries". ${ }^{1012}$ In their sui generis regime, Bierman and Boas include a "principle of collective rights for local populations" because such a regime "would need to be tailored for collectives of people". ${ }^{1013}$

1007 Alejandra Torres Camprubí Statehood Under Water: Challenges of Sea-Level Rise to the Continuity of Pacific Island States (Brill Nijhoff, Leiden, 2016), at 153.

1008 Essam El-Hinnawi Environmental Refugees (UNEP, 1985) at 4.

1009 Camprubí, above n 1007, at 151.

1010 Dana Zartner Falstrom "Stemming the Flow of Environmental Displacement: Creating a Convention to Protect Persons and Preserve the Environment" (2001) Colo J Int'l Env'l L \& Policy 1.

1011 Frank Biermann and Ingrid Boas "Preparing for a Warmer World: Towards a Global Governance System to Protect Climate Refugees" (2010) 10(1) Global Environmental Politics 60 at 75.

1012 At 74.

1013 At $75-76$. 
Others argue against a multilateral convention for dealing with climate migration. McAdam concludes that "a universal treaty may be inappropriate in addressing the concerns of particular communities". ${ }^{1014}$ Atapattu also recognises the practical challenge that "adopting a separate convention on environmental refugees could take years". ${ }^{1015}$ This prediction may be substantiated by the fact that the new Global Compact on Refugees and Global Compact for Migration are non-legally binding, voluntary, cooperative frameworks. ${ }^{1016}$

Another argument against a multilateral agreement is the challenge posed by seeking to address low-lying peoples' self-determination. This right is controversial in certain States and regions where there are secessionist movements, so attempting to protect it in a multilateral agreement would further hinder reaching broad agreement. ${ }^{1017}$ Even without the controversy, the perceived and actual competition between the self-determination of low-lying States and the territorial integrity and sovereignty of potential partner States would be an obstacle to reaching broad international agreement.

Regardless of the arguments for and against an international agreement, it remains an option. If pursued, and in order to minimise controversy, a multilateral instrument could recall and reiterate commitments elsewhere in international law regarding all peoples' right to self-determination. Also, regarding legal personality, it could rely on and restate options already provided for in Resolution 1541 and the Friendly Relations Declaration: "a sovereign and independent State, the free association or integration with an independent State or the emergence into any other political status freely determined". ${ }^{1018}$ Relying on current elements in international law might meet these needs

1014 Jane McAdam "Swimming Against the Tide: Why a Climate Change Displacement Treaty is not the Answer" (2011) 23(1) International Journal of Refugee Law 2 at 4.

1015 Atapattu, above n 583, at 626.

1016 Global Compact on Refugees, above n 1006, at I(A)(4); and Global Compact for Migration, above $\mathrm{n}$ 66, at [7].

1017 See Philip Stephens "Sovereignty and self-determination collide in Catalonia" Financial Times (online ed, London, 5 October 2017).

1018 Friendly Relations Declaration, above n 226, at 124; and see Resolution 1541, above n 424, Principle VI. 
of low-lying peoples without creating a significant barrier to broad international agreement.

\section{B. Soft Law Instruments and Voluntary Cooperation Initiatives}

Atapattu identifies that, given the obstacles for securing a binding and effective international solution, a more practical pathway is developing guiding principles or other soft law instruments, which may shape state practice and lay the groundwork for a later agreement. ${ }^{1019}$ Such developments are emerging, taking lessons from past and contemporary experiences and practices, resulting in sound general frameworks. International guidelines will need to be developed further to reflect the particular contexts where on-the-ground relocation initiatives take place, including where self-determination is at issue.

A number of multilateral and multi-country initiatives are emerging. None of them refer to protecting self-determination ex situ, but some of them are consistent with that goal. For example, at the General Assembly in 2016, States adopted by consensus the New York Declaration, which recognises climate change as a migration driver. ${ }^{1020}$ In that context, States declared "[w]e will ... ensure full respect and protection for their [refugees' and migrants'] human rights and fundamental freedoms." ${ }^{1021}$ The New York Declaration prefaced the development of the Global Compact for Migration, which rests on, amongst other things, the 1966 human rights Covenants, the UNFCCC, and the Paris Agreement, ${ }^{1022}$ all of which are pertinent to the low-lying States relocation scenarios. Like the New York Declaration, the Global Compact for Migration recognises climate change as a migration driver. ${ }^{1023}$ Against that backdrop, States committed to "[d]evelop coherent approaches to address the challenges of migration movements in the context of sudden-onset and slow-onset natural disasters". ${ }^{1024}$ However, the Global Compact for

\footnotetext{
1019 Atapattu, above n 583, at 632.

1020 New York Declaration, above n 83, at [1] and [43].

1021 At [22].

1022 Global Compact for Migration, above n 66, at [2].

1023 At [18(h)].

1024 At $[18(1)]$.
} 
Migration includes elements that could exacerbate the risks to self-determination associated with cultural assimilation, such as programmes intended to promote integration by educating migrants about social norms and customs in destination States. ${ }^{1025}$

These high-level developments were taking place at the same time as work was being undertaken on climate change-induced "migration, displacement and human mobility" by the Executive Committee on Loss and Damage. The Committee produced its first report on climate-related migration in 2018. ${ }^{1026}$ It recommended Parties incorporate "displacement, migration and human mobility ... into relevant planning and action encourage bilateral and multilateral entities to support such efforts". ${ }^{1027}$

More detailed approaches to climate-related migration have emerged from the State-led, State-sponsored, and multi-country initiative, the Platform on Disaster Displacement. The Platform succeeded the Nansen Initiative, which produced the Nansen Principles in 2011. ${ }^{1028}$ Those Principles relate to: collection of evidence, including from affected people; human rights; engagement with stakeholders, including international cooperation; and using development assistance to prevent displacement and finding durable solutions for where it cannot be prevented. ${ }^{1029}$ The Nansen Initiative later, in 2015, produced its Agenda for the Protection of Cross-Border Displaced Persons in the Context of Disasters and Climate Change (Protection Agenda). ${ }^{1030}$ This is an attempt to provide a conceptual framework and to identify effective practices for protecting displaced persons. This is more detailed than any of the multilateral initiatives discussed earlier, and it contains elements that resemble and would support efforts to enable

\footnotetext{
1025 Global Compact for Migration, above n 66, at [32(b)] and [32(f)]. See Chapter 1, Part III(B).

1026 UNFCCC, above n 82.

1027 Cancun Adaptation Framework, above n 10, at 14(f).

1028 Norwegian Refugee Council The Nansen Conference: Climate Change and Displacement in the 21st Century (Oslo, 5-7 June 2011) [The Nansen Principles].

1029 At 5.

1030 Protection Agenda, above n 405.
} 
low-lying peoples' ex situ self-determination. For example, the Protection Agenda identifies success factors in planned relocation, including: ${ }^{1031}$

\footnotetext{
... full respect of the rights of affected people ... taking into account community ties, cultural values, traditions, and psychological attachments to their original place of residence, and ensuring adequate livelihoods, basic services, and housing in the new location [plus] [s]ystematic engagement with women, in particular.
}

The work of the Platform on Disaster Displacement is increasingly localised, having recently partnered in a Pacific regional project with a syndicate of international and regional agencies. ${ }^{1032}$ The objectives of the project, titled "Enhancing Protection and Empowerment of Migrants and Communities Affected by Climate Change and Disasters in the Pacific Region", are: ${ }^{1033}$

\footnotetext{
... to support a regional human security-based response to climate change and disaster-related migration, displacement and planned relocation, ensure that migrants and communities benefit from safe labour migration where appropriate, and contribute to the evidence-base of good practices in these areas.
}

The right to self-determination remains a gap, since neither this project nor any other initiative is yet dealing with relocation solutions for peoples as-a-whole. However, the cumulative effect of these on-the-ground projects, plus soft law instruments and voluntary cooperation initiatives, is the development of expertise in relevant countries and agencies, and increasing awareness of the associated risks and support options. The momentum is also influencing national-level policy-making, such as Fiji's policy analysis on residency and citizenship issues for potential I-Kiribati climate migrants. ${ }^{1034}$ Importantly, issues of self-determination are also recognised in a human rights report by

\footnotetext{
1031 At 9.

1032 IOM, above n 87.

1033 IOM, above n 87.

1034 Office of the President of Kiribati, above n 89; and Sarah Taylor "Fiji prepares for 'climate refugees"' (17 November 2017) EuroNews <www.euronews.com>.
} 
the Samoan Ombudsman ${ }^{1035}$ and the right is a 'core value' in New Zealand's Pacific climate migration action plan. ${ }^{1036}$

\section{Regional Programme}

Another alternative to a multilateral treaty is a regional programme of action. A number of initiatives are emerging in the Pacific region. This began in 2008 with the Leaders of the PIF adopting the Niue Declaration on Climate Change, which proclaims that they are "deeply concerned" about Pacific States' "future survival". ${ }^{1037}$ Accordingly, the Leaders: ${ }^{1038}$

\footnotetext{
Comit[ted] ... to advocate and support the recognition, in all international fora, of the urgent social, economic and security threats ... to our territorial integrity and continued existence as viable, dynamic communities.
}

They also called upon the Pacific region's development partners to "increase their technical and financial support for ... if necessary, relocation". ${ }^{1039}$ At the 2016 PIF Leaders meeting, members adopted a voluntary Framework for Resilient Development in the Pacific (FRDP), which relates to climate change. ${ }^{1040}$ The vision of the FRDP is that "[w]e aspire for our Pacific people, our societies, economies, cultures and natural environments to be resilient to changing conditions and extreme events resulting from climate change". ${ }^{1041}$ One of the purposes of the FRDP is "a coordinated regional approach to addressing national priorities". ${ }^{1042}$

\footnotetext{
1035 Samoa National Human Rights Institute State of Human Rights Report 2017 (Office of the Ombudsman, September 2018) at 19.

1036 CAB-18-MIN-0218, above n 90.

1037 Niue Declaration, above n 7, at preamble, first recital.

1038 At [2].

1039 At [4].

1040 FRDP, above n 460.

1041 At 12.

1042 At 12.
} 
Several Pacific regional developments took place in 2018. The Polynesian Leaders Group (whose membership is smaller than the PIF) called for "a legal regime to protect people displaced by climate change" and "the establishment of a Grand Coalition of Pacific Leaders on Climate Change Displacement and Migration to find regional solutions to the issue of climate change displacement and migration." ${ }^{1043}$ Similarly, New Zealand's action plan was adopted and looks towards "facilitating a regional dialogue and exploring a regional instrument through the Pacific Islands Forum". ${ }^{1044}$ New Zealand anticipates that this dialogue will take place in light of "provocative questions of international law: for instance, how to maintain self-determination"1045 and underpinned by core values, including to "[r]espect and uphold Pacific Island countries' sovereignty and their right to self-determination". ${ }^{1046}$ The 2018 PIF Leaders meeting focused on climate change and security, not migration, but Forum Leaders acknowledged the significance of peoples in the Boe Declaration on Regional Security (Boe Declaration). The Leaders "reaffirm[ed] that climate change remains the single greatest threat to the livelihoods, security and wellbeing of the peoples of the Pacific". ${ }^{1047}$ An action plan for the Boe Declaration is currently under development ${ }^{1048}$ and it remains to be seen as to whether the recognition of the importance of peoples is linked to their right to self-determination. The final development in 2018 was a Pacific climate change forum co-hosted by New Zealand, the United Kingdom and the PIF. The report from the forum recognised that climate migration: ${ }^{1049}$

\footnotetext{
... should be through a lens of 'continuity of community', not just 'from Place A to Place B' [which] means thinking about moving whole communities (not just individuals), as well as preserving culture and political institutions.
}

\footnotetext{
1043 Amatuku Declaration, above n 88, at [9] and [11].

1044 CAB-18-MIN-0218, above n 90, at [2].

1045 At [12].

1046 At [23].

1047 Boe Declaration, above n 20, at [1] (emphasis added).

1048 Pacific Islands Forum Secretariat "Regional Policy Consultations - Boe Declaration Action Plan" (February 2019), available at <www.forumsec.org >

1049 Wilton Park, above n 6, at [29].
} 
More recently, the PIF has partnered with the syndicate of UN agencies in the project described in the previous sub-part, "Enhancing Protection and Empowerment of Migrants and Communities Affected by Climate Change and Disasters in the Pacific Region". ${ }^{1050}$

Whether through voluntary programmes or a legal regime, a regional approach is likely to be more relevant to affected peoples than a multilateral one, because: common contextual issues can be more readily reflected; it can be devised and implemented among fewer actors with fewer interests to reconcile; it can build on existing relationships; ${ }^{1051}$ and it has the potential for more ambition and greater detail, as is already evidenced in the developments in the Pacific.

\section{Bilateral Regime}

Mayer and Cournil "question the value of any abstract legal protection regime, rather than ad hoc political resettlement agreements". ${ }^{1052}$ Adopting this approach would lead the options towards discrete, bilateral dealings. Since the number of parties involved is limited, the interests at stake in negotiations are limited and alignment is more likely to be found. It will be important, however, that piecemeal arrangements do not impede the likelihood or potential for arrangements that seek to enable low-lying peoples' ex situ self-determination.

The Government of Fiji is carrying out policy analysis on residency and citizenship options for potential climate migrants from Kiribati, but details are not yet available. ${ }^{1053}$ Also, the New Zealand Government is building climate migration into its bilateral aid programming: its action plan on climate migration involves, inter alia, "utilis[ing] ODA

\footnotetext{
1050 IOM, above n 87.

1051 Chapter 3, Part II(C)(1).

1052 Benoît Mayer and Christel Cournil "Climate change, migration and human rights" in Quirico and Boumghar, above n 513, 173 at 186.

1053 Office of the President of Kiribati, above n 89; and Taylor, above n 1034.
} 
[official development assistance] to avert and delay climate-related displacement and prepare for Pacific climate migration." 1054

Fiji and New Zealand's initiatives are at early stages, so it is not clear how their intentions will translate into policy that is effective for climate migrants from low-lying States in the Pacific region. There are vast complexities requiring research, consultation, education, and the development and analysis of options, particularly ones that do not prejudice the achievement of ex situ self-determination in the longer-term. However, in comparison to regional or multilateral initiatives, there is greater potential for parties in a bilateral arrangement to address climate migration and to do so in a nuanced, relevant way. For example, details could address: the identification of low-lying islanders as people with the right to self-determination; the substantive and procedural aspects of the right; the legal personality of what is currently the low-lying State; issues regarding land holdings; and how the two States will seek to dovetail their normative systems.

\section{E. Reflecting on the Various Frameworks for Ex Situ Self-Determination}

If the peoples of low-lying States cannot adapt in situ to climate change, they will need a combination of instruments and initiatives that act as a modus vivendi and enable self-determination. Negotiating any treaty or voluntary cooperation initiative involves balancing hoped-for benefits and acceptable compromises. The key will be finding an acceptable combination of rights and duties for both themselves and partner States.

Theoretically, any initiative - whether international, regional or bilateral, or binding or non-binding - can address questions of self-determination and legal personality. But multilateral initiatives, such as the Global Compact for Migration, will likely remain high-level and less practical. Nevertheless, low-lying States need to continue to engage in such processes and to advocate for contents they deem essential to minimising the losses and damage in their predicaments, such as enabling ex situ self-determination.

1054 CAB-18-MIN-0218, above n 90 at [24]. 
More detailed tools for facilitating relocation enterprises are emerging through guidelines, voluntary cooperation initiatives and regional activities, and low-lying States can continue to lead and participate in such initiatives. Ultimately, however, bilateral agreements between low-lying and partner States will be the most useful mechanism: they can be particularised regarding self-determination; they are governed by international law; ${ }^{1055}$ and they cannot conflict the right to self-determination. ${ }^{1056}$

\section{The Human Rights-Based Approach to Climate Change Policies and its Application to Low-Lying Peoples' Relocation and Self-Determination}

Since climate change has far-reaching human rights implications, international discourse is increasingly considering the concept of a human rights-based approach (HRBA) to devising climate change policies. Notably, the Human Rights Council and the OHCHR are advocating for it in the context of dialogue and discussions regarding the UNFCCC and Sustainable Development Goals. ${ }^{1057}$ Broadly, the HRBA seeks to understand and address risks to human rights in various contexts, including climate change adaptation initiatives. ${ }^{1058}$ In relocation initiatives, the HRBA will need to take into account the risks that are specific to the migration process and the local contexts. It is submitted that, in cases of relocating a people, the HRBA should account for the need to promote and secure the enjoyment of self-determination. That collective right is, after all, a prerequisite to the protection and enjoyment of individual human rights. ${ }^{1059}$ To address self-determination, the HRBA will need to account for the right's substantive and

\footnotetext{
1055 VCLT, art 2(1), definition of "treaty", para (a).

1056 Chapter 2, Part V.

1057 OHCHR "Human Rights and Climate Change" <www.ohchr.org>; and Sustainable Development Goals, above n 347. See also Aled Dilwyn Fisher A Human Rights-Based Approach to the Environment and Climate Change (The Global Initiative for Economic, Social and Cultural Rights, Practitioner's Guide, 2014); OHCHR Applying a Human Rights-Based Approach to Climate Change Negotiations, Policies and Measures (Information Note, 2010); and other resources available at United Nations Development Group "UN Practitioners' Portal on Human Rights Based Approaches to Programming" <www.hrbaportal.org>.

1058 Gromilova, above n 48, at 81.

1059 Chapter 2, Part VI(A).
} 
procedural aspects. In doing so, the HRBA to relocation will complement initiatives regarding legal personality, land and legal frameworks.

This part outlines the HRBA, considers its potential limitations with respect to ex situ self-determination, and proposes how it could be expanded to encompass that collective right, including its substantive and procedural elements.

\title{
A. Background and Definition of the HRBA
}

The HRBA was originally devised for addressing vulnerable people's security and liberty in the development and humanitarian spheres, ${ }^{1060}$ and, therefore, applies to issues such as food and nutrition, education, and peace. ${ }^{1061}$ The OHCHR defines the HRBA as follows: ${ }^{1062}$

\begin{abstract}
A human rights-based approach is a conceptual framework that is normatively based on international human rights standards and operationally directed to promoting and protecting human rights. It seeks to analyze obligations, inequalities and vulnerabilities and to redress discriminatory practices and unjust distributions of power that impeded progress and undercut human rights.
\end{abstract}

Under a human rights-based approach, plans, policies and programmes are anchored in a system of rights and corresponding obligations established by international law.

In relation to climate change adaptation, a HRBA enables ex ante analyses of human rights risks in policies, programmes and projects, plus the development of indicators for monitoring and evaluation during and after implementation. Altogether, the HRBA ought

1060 United Nations Development Group "How do human rights standards relate to the development programming process?" United Nations Practitioners' Portal on Human Rights Based Approaches to Programming <hrbaportal.org>.

1061 See generally United Nations Development Group, above n 1057.

1062 OHCHR, above n 1057 (Information Note), at 1. 
to strengthen climate change adaptation initiatives by "promoting policy coherence, legitimacy and sustainable outcomes". ${ }^{1063}$

Given the enormity of risks in climate change relocation, a HRBA to the enterprise is especially important, as the ILA explains: ${ }^{1064}$

\footnotetext{
In a context where planned relocation becomes a necessary and viable option, policymakers

will need to pay acute attention to planning, embrace lessons learned from past experiences, prioritize a human rights-centred approach throughout the process, and involve and consult those to be relocated as well as host communities.
}

The ILA's Committee on International Law and Sea Level Rise has related this to self-determination, resolving that, "[g]iven their significance for indigenous peoples, States undertaking planned relocation shall respect and protect their rights to self-determination, culture, identity, land, and resources." ${ }^{1065}$ The next phase in developing this thinking is conceptualising what a HRBA to relocation might look like with respect to self-determination.

\section{B. Current Limitations for Self-Determination in the HRBA}

In situations where enjoyment of the right to self-determination is imperilled, and where a HRBA is being employed, it is submitted that the HRBA should address that collective right. After all, self-determination is an essential prerequisite for safeguarding individual human rights, ${ }^{1066}$ so ignoring this right would undermine the HRBA altogether in such situations.

The HRBA tends to focus on individual rights, but it does not exclude consideration of self-determination. For instance, the UN's Human Rights-Based Approach Toolkit

\footnotetext{
1063 Human Rights Council Human rights and climate change HRC Res 10/4 (2009) at preamble, tenth recital. See also OHCHR, above n 1057.

1064 ILA Committee on International Law and Sea Level Rise, above n 54, at 26-27 (citations omitted).

1065 Sydney Declaration, above n 427, at 6(4).

1066 Chapter 2, Part VI(A).
} 
guides practitioners to think broadly in identifying "which economic, social, cultural, civil, and political human rights are relevant". ${ }^{1067}$ Self-determination falls under that umbrella, but it is not acknowledged in the Toolkit. ${ }^{1068}$ Another HRBA manual produced by the UN Population Fund notes that, "[i]n some cases the equal worth and dignity of all human beings can only be assured through the recognition and protection of individuals' rights as members of a group". ${ }^{1069}$ This may be alluding to self-determination, but might only be referring the right to culture or the rights of indigenous peoples; it is unclear.

The UNHCR is explicitly forward-leading in its Guidance on Planned Relocation, in which Overarching Principle 11 brings together HRBA and self-determination, stating that: ${ }^{1070}$

\footnotetext{
Planned Relocation should be carried out within a rights-based framework that safeguards both individual and collective ... rights of Relocated Persons and Other Affected Persons throughout all phases. The rights to self-determination, preservation of identity and culture, and control of land and resources are important, particularly for indigenous communities.
}

Whilst the UNHCR's work on planned relocation starts a discussion about self-determination in a rights-based framework, the HRBA is fixed on individual rights. This is evident where the OHCHR argues for applying the HRBA to climate change policymaking to protect "the most pressing needs of vulnerable persons". ${ }^{1071}$ This notion is consistent with a more general phenomenon of human rights norms being "more concerned with avoiding the worst than with achieving the best." 1072

1067 United Nations A Human Rights-Based Approach Toolkit: Document B: The HRBA and the Basic Project Cycle: The Four Steps (United Nations Viet Nam) at 1.

1068 ICCPR, art 1(1); and ICESCR, art 1(1).

1069 United Nations Population Fund A Human Rights-Based Approach to Programming: Practical Implementation Manual and Training Materials (UNFPA, 2010) at 36.

1070 UNHCR, above n 99, at 12. See also UNHCR A Toolbox: Planning Relocations to Protect People from Disasters and Environmental Change (Brookings Institute, Georgetown University and UNHCR, 2017) at 12, which includes "collective rights" in a checklist of legal issues to be considered.

1071 Pansieri, above n 140 [emphasis added].

1072 James Nickel "Human Rights" in Edward N Zolta The Stanford Encyclopedia of Philosophy (online ed, Standford CA, 8 November 2014). 
Should that tendency persist in low-lying peoples' relocation, there is a risk the HRBA will prioritise individuals' basic human security needs over, and at the expense of, the collective right to self-determination. Protecting the individual rights of persons in dire situations with acute needs is imperative. However, other human rights, interests and endeavours still matter. Officials from States that are especially vulnerable to climate change talk of fairness, equity and dignity, ${ }^{1073}$ and "the importance of retaining the Pacific's social and cultural identity". ${ }^{1074}$ Similarly, indigenous voices advocate for a "holistic view of life and community". ${ }^{1075}$ The HRBA needs to respond to these concerns, not just "the most pressing needs" of individuals.

Enabling ex situ self-determination will obviously be complex and demanding, in terms of development support, but the HRBA for low-lying people's situations should expect policy-makers and practitioners to delve into the right's substantive and procedural aspects. We can foresee the risks to self-determination, and have time and capacity for advance planning, and for integrating these concerns into near-term support activities via models such as the HRBA.

\section{Detailing Self-Determination in a HRBA to Climate-related Relocation}

An important intellectual milestone was reached in the UNCHR's recognition of self-determination in the context of planned relocation. However, "international law as it currently stands does not spell out the implications of the right to self-determination". ${ }^{1076}$ This thesis has conceptualised self-determination as a bundle of rights, both substantive and procedural. ${ }^{1077}$ This framework improves our understanding of the right and also demystifies how to incorporate the self-determination - via the set of clearer substantive and procedural entitlements - into existing HRBA planning tools, such as the UNHCR's

1073 Human Rights Council Summary report of the Office of the United Nations High Commissioner for Human Rights on the outcome of the full-day discussion on specific themes relating to human rights and climate change $\mathrm{A} / \mathrm{HRC} / 29 / 19$ (2015) at [17] and [19].

1074 Niue Declaration, above $\mathrm{n} 7$, at preamble, fifth recital.

1075 OHCHR "Council discusses measures that can be adopted by States in addressing the effects of climate change on Human Rights" (press release, 6 March 2015) at 6.

1076 Badinter Commission on Yugoslavia, above n 235, at 1498; and see Chapter 3, Part V(B).

1077 Chapter 2, Part VII. 
Toolbox for planned relocation ${ }^{1078}$ and the UN's Your HRBA Checklist. ${ }^{1079}$ These HRBA tools contain lists of questions to guide practitioners and policymakers in identifying and addressing human rights risks in their programmes. This section proposes a new self-determination element that should be included in those planning tools, including questions relevant to the right's substantive and procedural elements, and to cross-border relocation. In the existing tools, questions are framed so they are closed but leading prompts. Thus, the new questions proposed here are drafted to conform with that style.

The new checklist proposed (in the style of the UNHCR Toolkit) could be headed, "With Respect to Relocated Peoples' Right to Self-Determination". It would begin with the substantive elements, ${ }^{1080}$ with questions such as:

- Are the Relocated Persons recognised collectively as a People who have the right to self-determination?

- In their place of origin, do the People have an existing State or other political status?

- Is there a common understanding among key stakeholders of how that State or political status will be enabled or modified in the territory of the destination/partner State?

- Is there a common understanding among key stakeholders of how the People will freely pursue their economic, social and cultural development in the territory of the destination/partner State?

- Is there a common understanding among key stakeholders of the People's own means of subsistence during and after relocation?

- Is there a common understanding among key stakeholders of what comprises the People's natural wealth and resources which they may freely dispose?

1078 UNHCR, above n 1070.

1079 United Nations A Human Rights-Based Approach Toolkit: Document E: Your HRBA Checklist (United Nations Viet Nam).

1080 Chapter 2, Part VII(A). 
The limitation of "in the territory of the destination/partner State" is excluded from the last two of those questions. This is because these natural resources may come from the partner State's territory as well as the low-lying people's current territory, such as from their maritime zones.

The second set of questions would relate to the procedural aspects of self-determination, some of which reflect other civil and political rights, and all of which can help safeguard the substantive aspects of self-determination. ${ }^{1081}$ The questions are:

- Are there participatory, democratic systems enabling the free and genuine expression of the will of the people, without external interference, regarding the substantive aspects of self-determination?

- Are relevant civil and political rights - including those in the ICCPR; Articles 19 (freedom of expression), 21 (peaceful assembly), 22 (freedom of association) and 25 (take part in public affairs) - being linked to the right to self-determination?

- Do diaspora enjoy relevant civil and political rights relative to the political entity of their State of origin?

- Is there a common understanding among key stakeholders of the autonomy of the people to determine, develop and enforce their own norms?

- Is there a common understanding among key stakeholders of how the people's autonomy will function relative to the normative systems of the destination State?

To guide practitioners in answering such questions, the checklists should be prefaced with important context. In particular, guidance materials ought to set out the objectives of self-determination, which are peace and friendly relations, enabling other human rights, and protecting identity. ${ }^{1082}$ Guidance materials should also set out the risks

1081 Chapter 2, Part VII(B).

1082 Chapter 2, Part VI(A). 
that are known in relocation, such as the categories of impoverishment developed by Cernea, including marginalisation and social disarticulation, plus the additional impoverishment risk category of cultural assimilation proposed in this thesis. ${ }^{1083}$ The risks to self-determination and impoverishment are particular to relocation, but guidelines for understanding and addressing those challenges would complement guidelines already available on human rights and Sustainable Development Goals.

\section{Concluding on the HRBA to Ex Situ Self-Determination}

Climate change adaptation measures, such as relocation, can exacerbate or create other problems. Hall and Weiss refer to this as "the growing threat of 'adaptation apartheid"'. ${ }^{1084}$ The HRBA provides an important platform from which to avoid such maladaptation by establishing "human rights thresholds"1085 and guiding communities and policymakers towards seeing that "these rights duties can be ensured". ${ }^{1086}$ In large-scale relocation enterprises, such as those that may fall upon low-lying peoples, it will be necessary to address explicitly the substantive and procedural aspects of self-determination in light of its objectives. Actions and policies following that process should help guide dialogue towards some of the key issues presented in this thesis of legal personality, land and legal frameworks. In this way, the HRBA can help convert the opaque, abstract notion of self-determination into a practical toolkit. The HRBA is not a panacea and the relocation enterprise will be extremely challenging, even within that framework. As Gromilova identifies, the realisation of self-determination in relocation: ${ }^{1087}$

... presents a huge technical, physical, and financial difficulty, as it would mean that resettlement should guarantee that people remain within their community, and thus the whole community has to be relocated to one new place.

\footnotetext{
1083 Chapter 1, Part III(B).

1084 Hall and Weiss, above n 425, at 314.

1085 International Council on Human Rights Policy Climate Change and Human Rights: A Rough Guide (2008) at 17-21. Note that the phrase "minimum standards" does not mean "low standards". What is "minimum" is established by the parties: "below this standard or threshold is not acceptable".

1086 Gromilova, above n 48, at 88.

1087 Gromilova, above n 48, at 87.
} 
Diasporic cosmopolitanism ameliorates the challenge of "one new place". Nevertheless, there are many practical challenges in establishing ex situ self-determination. It is submitted, however, that they are all solvable. There are years, or even decades, available for planning and implementing climate change relocation consistent with self-determination. Furthermore, any relocations that occur in the interim can either be conducted so that relocated people remain connected with their original community, or such connectivity can be developed retrospectively. Moreover, the erga omnes obligations, and probably peremptory status of self-determination prevents it from being optional simply because it is difficult.

\section{Discussion, including Hypotheticals to Illustrate how the Options can be Assembled for a Holistic Relocation Enterprise}

This chapter has discussed various options for enabling self-determination relating to legal personality, land and international frameworks. All those options can be tailored to meet the needs and hopes of the peoples of low-lying and partner States. The resulting sui generis solutions will need numerous complementary policy and programme-level measures to address practical, social, cultural and economic concerns. However, to illustrate the potential for designing ex situ self-determination solutions, two hypothetical combinations of options are described below. These are simple, minimal examples; not scenario planning. And these hypotheticals are not proffered as "best" options. They serve merely to illustrate two of the many different ways parties could assemble the various options for legal personality, land and international frameworks, which in turn might support low-lying peoples' ex situ self-determination. As well as illustrating the potential assemblages, these simple models also help identify risks in greater detail.

\section{A. Hypothetical A}

In the first hypothetical, which is illustrated in Figure 2 below, the low-lying State that is relocating to the territory of a partner State begins by consulting widely on a relocation threshold, that is, the point at which conditions have deteriorated such that the relocation programme will be triggered. The low-lying State and its people can discuss how the 
relocation enterprise might take place. A referendum is held to empower the people to decide on their State's international legal personality and relevant competencies, as often occurs in self-determination situations. ${ }^{1088}$ The people vote to maintain statehood during and following relocation to the partner State's territory. This does not compel the sovereign partner State, which is concerned about whether the international community would entertain this unprecedented model. Therefore, the low-lying State bolsters support for its ex situ statehood by seeking support and ongoing recognition from like-minded international partners, such as other low-lying and small island developing States.

In terms of land, the low-lying State has no territory within the jurisdiction of the partner State. Instead, it purchases land as real property, with support from multilateral finance mechanisms, such as the Green Climate Fund, ${ }^{1089}$ as well as bilateral aid funding.

Regarding the legal framework, the low-lying State enters into a bilateral treaty with its partner State. In that agreement, the Parties agree that the low-lying State maintains statehood. They agree that the relocating people remain citizens of the low-lying State, but will also enjoy the same rights as citizens of the partner State. The Parties also reaffirm that the low-lying State's rights to natural resources, including those in its pre-existing maritime zones, are maintained. The agreement details the division of authority, including the rights and duties of both parties in respect of the low-lying State's land, property and peoples, and matters of taxation and revenue supply are determined.

The bilateral agreement also provides for the establishment of a sui generis trust. The trust will be the low-lying State's municipal legal personality within the jurisdiction of the partner State and created through statute. This enables the low-lying people's and their State's ownership and governance of property within the partner State's territory.

1088 Cassese, above n 146, at 17; Crawford, above n 169, at 320; Knop, above n 176, at 13 and 281-284; and Raič, above n 148, at 424 (citations omitted).

1089 The Green Climate Fund is a multilateral funding mechanism established under the UNFCCC: Cancun Adaptation Framework, above n 10, at [102]. 
The trust owns and manages certain systems for maintaining the low-lying people's connectivity as a community and as a nation while they relocate to various locations within the partner State as well as elsewhere throughout the region (for example, other Pacific States). The connectivity systems include purpose-made websites and email accounts that use the low-lying State's domain suffix codes (such as .ki for Kiribati or .mv for the Maldives), as well as social media accounts. Together, these systems support networking, access to government information and services, and education, including cultural and language teaching. While a core of people moves to one geographic location, other members will likely move elsewhere in the partner State's territory or to other countries, so the connectivity systems help mitigate the associated challenges for the maintenance of community and national identity.

Figure 2: Flow diagram illustrating Hypothetical A.

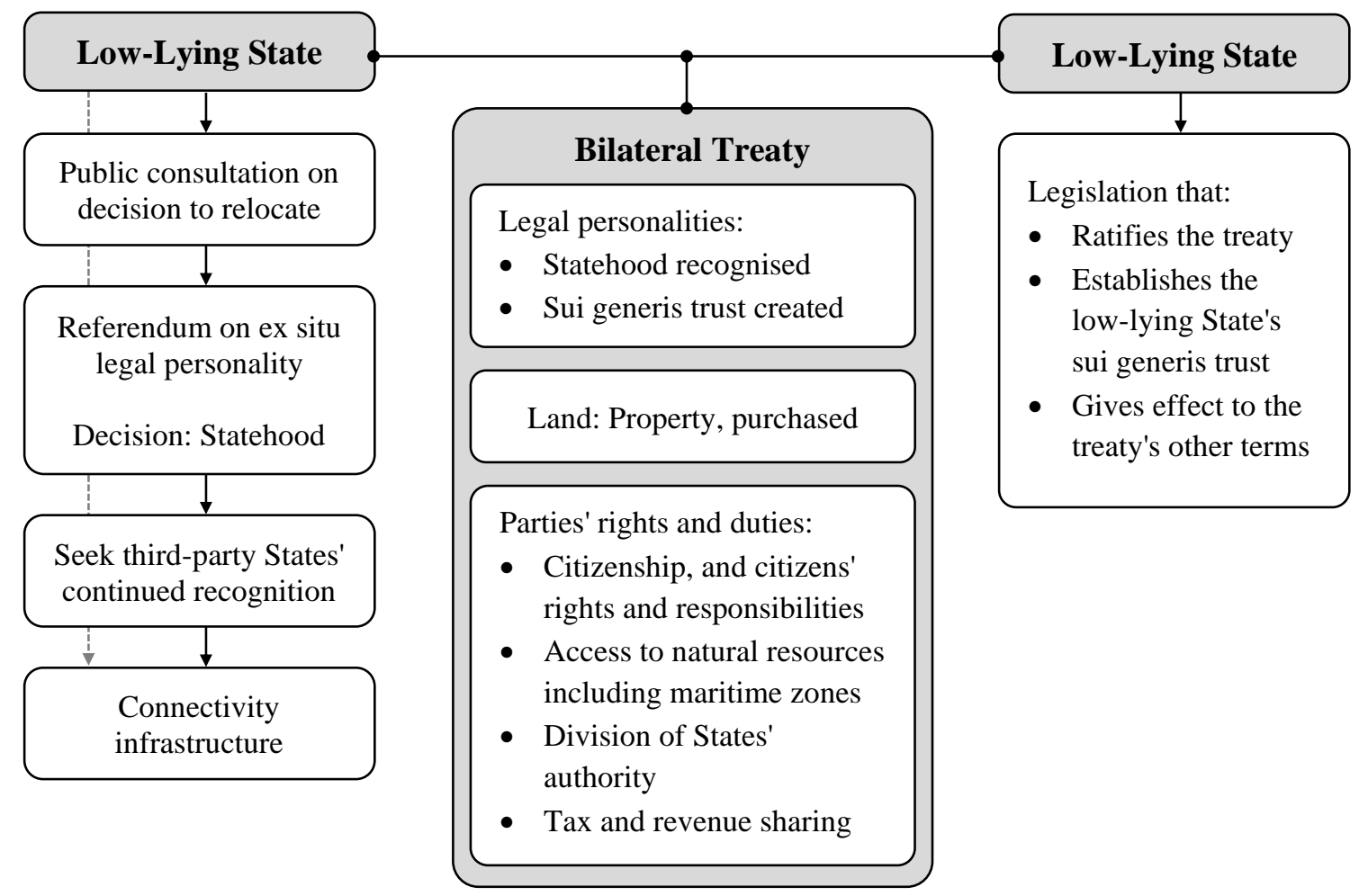




\section{B. Hypothetical B}

In the second hypothetical, illustrated in Figure 3 below, the low-lying State that is relocating to the territory of a partner State begins by enacting legislation to confirm its official language and flag. It conducts a referendum on its international legal status and the people vote to change to a sui generis sovereign entity akin to the Order of Malta. The way this option was presented includes the new entity maintaining its membership and participation in international and regional organisations.

The low-lying State enters into a bilateral treaty with a partner State, which confirms: the low-lying State's new international legal personality and sovereign status; the low-lying peoples' right to self-determination and human rights in international law; that low-lying States' citizens gain dual citizenship upon relocating to the partner State's territory; and the delegation of certain powers to the partner State, such as taxation.

The treaty also deals with issues of land and territory. The low-lying State leases in perpetuity the land onto which it relocates. In exchange, the two States parties institute condominium arrangements with respect to limited parts of their maritime zones. The low-lying State and the partner State share sovereign rights over those segments of each other's zones to support and boost their respective fishing industries.

The bilateral treaty also establishes, in the jurisdiction of the partner State, a sui generis juridical entity to represent the low-lying people. The entity has a constitution that recognises its special status, and sets out matters regarding governance and elections. It is endowed with certain rights, such as the ability to adjudicate and enforce its own norms within its property boundaries where those norms do not conflict with the laws of the partner State. The partner State passes special legislation that ratifies the treaty, and gives effect to its terms, including the creation of the low-lying State's special juridical entity. 
Figure 3: Flow diagram illustrating Hypothetical B.

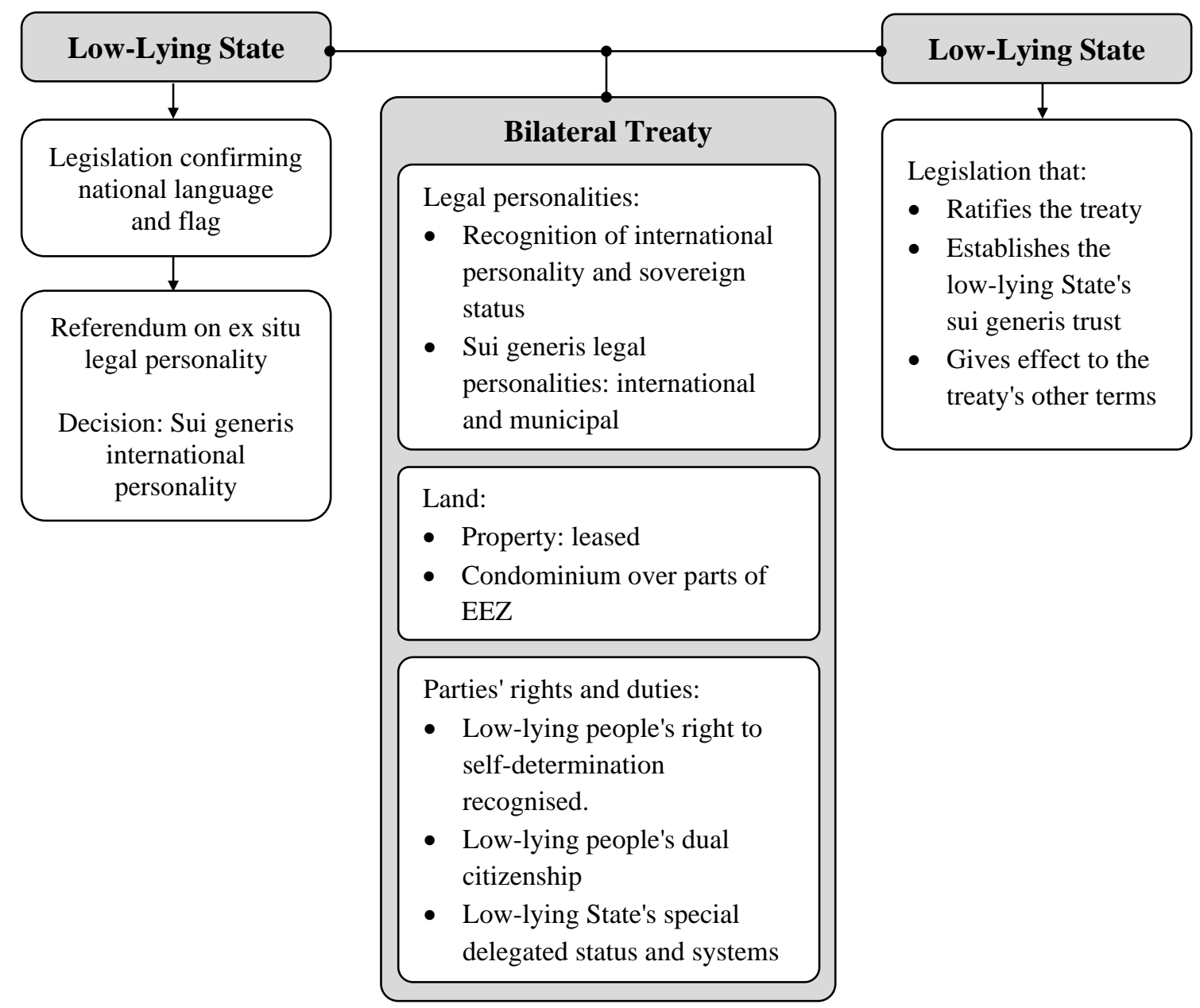

VII. Conclusion

These simple hypotheticals reveal major policy questions. For example, how will the peoples assert their exclusive competence on questions of international legal personality in the difficult circumstances? How will jurisdictional issues be resolved when complex, discrete issues arise "on the ground"? What dispute resolution systems will be fit-for-purpose? At the same time as asking such difficult questions, the hypotheticals also illustrate the possibilities and help to shift the thinking away from "disaster" hyperbole. 
Climate relocation is inherently harmful, but developing such hypotheticals helps with scenario planning and story-telling. In turn, it becomes possible to imagine futures whereby self-determination is at the heart of the narrative; not disaster.

This chapter has shown a range of tools which are available for enabling ex situ self-determination. These include: international legal personalities; municipal legal personalities; different means by which land can be held; and multilateral, regional and bilateral tools for framing the enterprise. This work can be supported by systems for facilitating diasporic cosmopolitanism, and by guidelines with international usage, such as the HRBA, which can be expanded to include self-determination's substantive and procedural entitlements as objectives and success indicators of the relocation enterprise. 


\section{Chapter 6: Conclusion}

The populations of each of the low-lying States are peoples who have the right to self-determination in international law. They currently enjoy this right, in part through having freely determined their political status as statehood. Climate change poses the risk that whole, or very large proportions of these peoples will need to migrate across international borders. To avert this forced relocation, the global community needs to reduce greenhouse gases and support in situ adaptation measures rapidly and at scale. However, it is increasingly unlikely this will occur, so this en masse cross-border relocation will become necessary.

Previous experience demonstrates that forced relocations cause an array of profound problems for affected migrants, at individual and community levels, known as "impoverishment risks". Moreover, if individuals move to more than one State and to more than one region within destination States, then the low-lying peoples will be fragmented, affecting them at a societal level. Such possibilities underlie low-lying islanders' concerns about the risks to their national identities, cultures and languages. Taken together, and through the lens of international law, these risks threaten to undermine low-lying peoples' ongoing enjoyment of self-determination, including the continuity of their States.

Relocation of any scale, but particularly such that it enables self-determination, poses considerable practical and political challenges, as well as competing interpretations of legal rights and duties. Therefore, addressing the low-lying peoples' predicaments requires a common understanding for why the enterprise might be so ambitious, what self-determination might entail, and the many starting points available for this undertaking.

There are compelling reasons why the low-lying peoples' current enjoyment of the right to self-determination ought to be protected in a relocation enterprise. In international law, self-determination imposes obligations erga omnes and it arguably is a jus cogens norm. Accordingly, this right and its status must feature in relevant bilateral and other 
relevant dialogues. Functionally, self-determination is a foundation for peace and security, and for individual human rights. As international experience illustrates, depriving a people of self-determination can be calamitous, creating intractable social, cultural and economic impacts.

Whilst there are clear reasons for enabling ex situ self-determination, it has previously been unclear what this right entails. This thesis enhances our understanding of self-determination and its implications for the peoples of low-lying States. First of all, it demonstrates that self-determination is a right that belongs to a people, and which is not limited to a particular territory nor to decolonisation situations. There is, therefore, no principled reason why low-lying islanders would lose their right de jure to self-determination if they cross international borders en masse.

Another innovation has been to borrow the "bundle of rights" framing concept from property law to understand self-determination. This thesis proposes that, as well as self-determination being a right in itself, it is also comprised of other, derivative rights. This bundle of derivative rights includes substantive and procedural entitlements. The first substantive entitlement is statehood. This right exists only under very limited circumstances, but includes where statehood already exists and, therefore, there is a right to its continuity. The next substantive aspect is the recognition of a group of individuals as being a collective 'people'. This recognition amounts to a right to be different. The third substantive entitlement is the peoples' political status, freely determined. Continuity of statehood is one option, but another political status may be chosen. The final substantive element of self-determination is the right to economic, social and cultural development, and, related, the permanent sovereignty over, and right to dispose of, natural wealth and resources. Although these development trajectories could be deemed procedural rights, relevant decisions have considerable substantive outcomes that relate to, for instance, the people's national identity and ways of life.

The procedural rights derived from self-determination begin with very broad requirements, such as "take practical steps" and "facilitate the exercise of this right". Other procedural entitlements relate to implementing the substantive aspects of 
self-determination, such as peoples having the right "freely to determine, without external interference" their political status and to "pursue" their economic, social and cultural development. ${ }^{1090}$ These broad principles about procedures have been given effect in other situations through elections, referenda, plebiscites, constitutional development processes, and general consultation. The expectation of the peoples as being central to these processes has led to the emergence of democratic governance being considered a functional requirement for self-determination. This right is thereby linked to certain other civil and political rights, such as the right to take part in the conduct of public affairs, and to vote and be elected. These decision-making processes have the potential to deliver outcomes that reflect the wishes of the people, and to reflect the people's social and cultural practices and norms.

The sum total of self-determination and its derivative entitlements is that it is about a people having some meaningful degree of autonomy to define, discuss, modify and enforce their own norms, free from involuntary domination by another group. When a people shares geographic space with another people, self-determination anticipates dovetailing of the two (or more) peoples' normative systems, including power-sharing arrangements. Low-lying peoples in a relocation enterprise will be in other peoples' territories, obviously. Thus, a key difficulty will be in overcoming the lack of definition on the extent of this autonomy, and why, when and how normative systems can be dovetailed. There is a power imbalance weighing in favour of the destination State, so it seems very likely that low-lying States will need to make considerable compromises. However, this can be ameliorated by understanding that normative pluralism can take shape in a variety of ways. It can range from reliance on general democratic and human rights systems through to sophisticated systems that seek to respect and enable differences. The architecture and operationalisation of dovetailing autonomies will no doubt be guided by precedent situations, as well as by the power imbalance, but the low-lying peoples' right to self-determination remains highly relevant given its status in international law. 
In devising a new understanding of self-determination, other key elements analysed in this thesis were the duty-bearers and their duties. The thesis identifies actors with responsibilities towards the peoples who are the rights-holders, and the general nature and scope of those responsibilities. The low-lying States are the only particular duty-bearers with responsibilities towards particular peoples, those being, of course, their own peoples. No third-party State has such particular duties, which is the critical risk in this enterprise. However, there is a general duty on all States to promote and respect self-determination, including through international cooperation. This includes obligations to refrain from actions that adversely affect low-lying peoples' self-determination. For example, there is a duty on third-party States not to withdraw recognition of low-lying States' statehood. Third-party States' responsibilities also include general positive obligations to promote, render assistance, and cooperate with the UN to support a people's self-determination. For example, this may involve supporting low-lying States' ongoing membership of international organisations. Another example, stemming from the Paris Agreement, is continuous support for climate change adaptation measures led by affected groups, which may include initiatives to enable ex situ self-determination. These general duties will become more pointed for a partner State as it works with the low-lying State, international organisations, and other stakeholders to decide jointly how to give effect to this right.

As already indicated, the law of self-determination is relevant to questions raised regarding whether low-lying States can maintain statehood in the case of en masse relocation. Previous attempts to answer this question rely heavily or entirely on the Montevideo Convention indicia for the creation of new States. However, that treaty does not address questions about the potential termination of existing States. The critical elements of international law for this question are, first, the presumption of continuity, according to which exogenous forces cannot terminate statehood, and secondly, the right to self-determination, which provides that a people is entitled to freely determine, without external interference, its political status. Put simply, the peoples low-lying of low-lying States are exclusively competent to determine whether their statehood continues ex situ. Even if the Montevideo Convention was applicable to continuity questions, there are existing States which exhibit less than full satisfaction of the statehood indicia, so those indicia are guidance only. The loss of a permanent population or defined territory would 
not be a milestone with legal effect insofar as extinguishing statehood. This is especially true when the Montevideo analysis is considered in light of the presumption of continuity and the peoples' right to self-determination. Any attempt to override low-lying States' exclusive competence to deal with their political status could amount to an interference in their internal affairs and their right to self-determination.

Although the low-lying peoples all have the right to self-determination ex situ, there are major challenges in effectuating it in partner States' territories. In looking at options, this thesis has focused on issues regarding legal personality, land, and international frameworks. On legal personality, if the outcome sought is self-determination, then it is not simply "statehood or no statehood"; there are various options with varying of degrees of autonomy. At one end of the range is statehood, which affords a suite of exclusive rights and privileges, and is the strongest foundation for enabling ex situ self-determination. Then there are alternative international legal personalities that low-lying peoples could adopt. These include free association or integration models, such as suzerainties or federations, respectively. Further options fall under the unbounded notion of "any other political status", encapsulated in the Friendly Relations Declaration. Various State-like entities provide models that can be adapted, including NSGTs and sui generis entities, such as the Order of Malta.

This thesis has also suggested that low-lying peoples might adopt a municipal legal personality within the jurisdiction of the partner State. Options include trusts, corporations, incorporated societies, and sui generis juridical entities. A municipal legal person could be established in addition to an international legal personality, to complement the rights and privileges that come with that. On its own, however, a municipal legal personality has fewer protections or outward signs of autonomy. In any event, municipal personalities at least offer prospects for collective ownership and management ('governance') of collective ('public') assets, and therefore have the potential to enable internal self-determination.

Another practical issue addressed in this thesis is land. Again, there are options, so it is not simply 'territory or no territory'. Low-lying peoples might acquire new territory 
from a partner State through cession, or sale and purchase. While it is difficult to envisage a partner State conceding territory, it may only need to be a very small area; enough to support the low-lying States' statehood. Land may also be organised as a condominium, whereby the two States share sovereignty over the same parcel of territory in some agreed fashion. A low-lying State might otherwise obtain land via a lease, which may include conditions that resemble sovereignty, as in the case of the United States' rights in Guantánamo Bay. Or it may purchase land as property. In all cases, the form of land tenure does not affect individuals' right to freedom of movement, and so systems enabling diasporic cosmopolitanism might help to maintain cohesion and collective identity.

In regards to international frameworks for facilitating ex situ self-determination, there is a gap in the multilateral system for climate migrants. This is despite some non-binding progress and soft law developments, both internationally (such as the Global Compact for Migration) and regionally (such as the FRDP and the Boe Declaration). There are options for filling this gap with either multilateral, regional or bilateral approaches, but arguably, the most important developments will be bilateral. Multilateral and regional developments will be high-level and provide little more than general principles. Bilateral arrangements will, therefore, be necessary for capturing crucial details.

The implementation of such an agreement and, indeed, the relocation enterprise per se, can be enhanced by using a HRBA, particularly if it is tailored to meets the needs of low-lying peoples. In particular, a HRBA can reflect self-determination's essential role in safeguarding individual human rights by including elements targeted towards the collective right's substantive and procedural entitlements. These, plus any other priority issues for low-lying peoples, can be incorporated into tools developed to support the relocation.

With the spectre of forced en masse relocation, and the resulting risks to self-determination and statehood, low-lying peoples are uniquely imperilled by the greenhouse gas pollution of other States. It would be naïve to assume that improving anyone's understanding of these risks would result in a practical and adequate response. 
However, progress requires agreement on the facts and the law. Thus, in an effort to contribute to resolving the low-lying peoples' challenges, this thesis has defined the problem; explicated the right to self-determination; re-assessed the statehood question in light of self-determination; and set out a series of options for enabling ex situ self-determination that have precedent in international and municipal practice. 


\section{Bibliography}

\section{Primary Sources}

\section{A. Treaties and Statutes}

\section{International, Regional and Bilateral}

African Union Convention for the Protection and Assistance of Internally Displaced Persons in Africa (Kampala Convention) (opened for signature 22 October 2009, entered into force 6 December 2012).

Agreement between the Government of Malta and the Government of the Sovereign Military Hospitaller Order of St John of Jerusalem, of Rhodes and of Malta (signed 5 December 1998).

Agreement Between the United States and Cuba for the Lease of Lands for Coaling and Naval stations (23 February 1903) [Guantánamo Bay Lease Agreement].

Agreement Establishing the Asian Coconut Community 684 UNTS 163 (opened for signature 12 December 1968, entered into force 30 July 1969).

Agreement establishing the Pacific Islands Forum [2005] ATNIF 28 (signed 27 October 2005, not yet in force).

Charter of the Organization of American States 1609 UNTS 48 (opened for signature 30April 1948, entered into force 13 December 1951).

Charter of the United Nations 1945.

Compact of Free Association, as amended, Between the Government of the United States of America and the Government of the Republic of the Marshall Islands [2004] (signed 30 April 2003, entered into force 1 May 2004).

Convention between the United Kingdom and China respecting an extension of Hong Kong territory (signed 9 June 1898, entered into force 6 August 1898).

Convention Concerning Forced Labour C29, International Labour Organisation C29 (adopted 28 June 1930, entered into force 1 May 1932).

Convention on Access to Information, Public Participation in Decision-Making and Access to Justice in Environmental Matters 2161 UNTS 447 (opened for signature 25 June 1998, entered into force 30 October 2001) [Aarhus Convention].

Convention Relating to the Status of Refugees 189 UNTS 137 (opened for signature 28 July 1951, entered into force 22 April 1954) [Refugee Convention].

Convention Relating to the Status of Stateless Persons 360 UNTS 117 (opened for signature 28 September 1954, entered into force 6 June 1960). 
Covenant of the League of Nations 1919.

Framework Convention for the Protection of National Minorities ETS 157 (1 February 1995). [National Minorities Convention]

The General Framework Agreement for Peace in Bosnia and Herzegovina (signed 14 December 1995) [Dayton Peace Accords].

Geneva Convention for the Amelioration of the Condition of the Wounded and Sick in Armed Forces in the Field (First Geneva Convention) (signed 12 August 1949, entered into force 21 October 1950) 75 UNTS 31.

Geneva Convention for the Amelioration of the Condition of Wounded, Sick and Shipwrecked Members of Armed Forces at Sea (Second Geneva Convention) (signed 12 August 1949, entered into force 21 October 1950) 75 UNTS 85.

Geneva Convention Relative to the Treatment of Prisoners of War (Third Geneva Convention) (signed 12 August 1949, entered into force 21 October 1950) 75 UNTS 135.

Geneva Convention Relative to the Protection of Civilian Persons in Time of War (Fourth Geneva Convention) (signed 12 August 1949, entered into force 21 October 1950) 75 UNTS 287.

International Covenant on Civil and Political Rights 999 UNTS 171 (opened for signature 16 December 1966, entry into force 23 March 1976) [ICCPR].

International Covenant on Economic, Social and Cultural Rights 993 UNTS 3 (opened for signature 16 December 1966, entered into force 3 January 1976) [ICESCR].

International Convention on the Protection of All Migrant Workers and Members of Their Families 2220 UNTS 3 (opened for signature 18 December 1990, entered into force 1 July 2003) [Convention on Migrant Workers].

Kyoto Protocol to the United Nations Framework Convention on Climate Change 2303 UNTS 162 (opened for signature 11 December 1997, entered into force 16 February 2005).

Maritime delimitation treaty between Jamaica and the Republic of Colombia (12 November 1993).

Montevideo Convention on Rights and Duties of States 165 LNTS 19 (opened for signature 26 December 1933, entered into force 26 December 1934) [Montevideo Convention].

Paris Agreement (opened for signature 16 February 2016, entered into force 4 November 2016) [Paris Agreement].

Peace Treaty between the Holy Roman Empire and the King of France and their respective Allies (24 October 1648) [Treaty of Westphalia].

Respecting the Polish Forces in the United Kingdom AIR 2/4213 and WO 33/2389, National Archives, London.

Statute of the International Court of Justice 1945.

Treaty Between the Holy See and Italy in the Name of the Most Holy Trinity (1929). 
Treaty between the United States of America and the French Republic (Louisiana Purchase Treaty), 30 April 1803.

Treaty Defining Relations with Cuba, United States-Cuba 48 Stat 1683, TS 866 (29 May 1934).

The Treaty of Peace between the Allied and Associated Powers and Germany (signed 28 June 1919) [Treaty of Versailles].

Treaty of Waitangi 1840.

United Nations Convention on the Law of the Sea 1833 UNTS 3 (opened for signature 10 December 1982, entered into force 16 November 1994) [UNCLOS].

United Nations Declaration on the Rights of Indigenous Peoples GA Res 61/295, A/Res/61/295 (2007), annex ('United Nations Declaration on the Rights of Indigenous Peoples') [UNDRIP].

United Nations Framework Convention on Climate Change 1771 UNTS 107 (opened for signature on 9 May 1992, entered into force 21 March 1994) [UNFCCC].

Universal Declaration of Human Rights GA Res 217 A(II) (1948).

Vienna Convention on the Law of Treaties 1155 UNTS 331 (opened for signature 23 May 1969, entered into force 27 January 1980) [VCLT].

\section{Domestic Jurisdictions}

Aboriginal and Torres Strait Islander Act 2005 (AU).

Alaska Native Claims Settlement Act, Public Law 92.203 (1971) (AK, US).

Te Awa Tupua (Whanganui River Claims Settlement) Act 2017 (NZ).

Constitution of the Independent State of Papua New Guinea, Constitutional Amendment No. 23 - Peace-Building in Bougainville - Autonomous Bougainville Government and Bougainville Referendum (2002), s 281(1).

Constitution of Niue (1974).

Constitution of the Principality of Liechtenstein 2003.

Constitution of the Republic of Fiji 2013.

Constitutional Charter and Code of the Sovereign Military Hospitaller Order of St. John of Jerusalem of Rhodes and of Malta (1961).

Cook Islands Constitution Act 1964.

Corporations (Aboriginal and Torres Strait Islander) Act 2006 (AU).

Exclusive Economic Zone Outer Limit Regulations 2014 (KI).

Federal Constitution of the Swiss Confederation 1848.

Federal Constitution of the Swiss Confederation 1999.

Hineuru Claims Settlement Act 2016 (NZ). 
Human Rights Act 1993 (NZ).

Incorporated Societies Act 1908 (NZ).

Letters Patent Constituting the Office of the Governor-General of New Zealand (28 October 1983), SR 1983/225.

Māori Trust Boards Act 1955 (NZ).

Maungaharuru-Tangitū Hapū Claims Settlement Act 2014 (NZ).

New Zealand Bill of Rights Act 1990.

Raukawa Claims Settlement Act 2014 (NZ).

Tokelau (Territorial Sea and Exclusive Economic Zone) Act 1977 (NZ).

Tūhoe Claims Settlement Act 2014 (NZ).

\section{B. Cases (Courts, Arbitrations, and Investigations)}

1. International and Regional

Accordance with International Law of the Unilateral Declaration of Independence in Respect of Kosovo [2010] ICJ Rep 403 [Kosovo Independence advisory opinion].

Al-Adsani v United Kingdom (Euro Court of HR, Application no. 35763/97, 21 November 2001).

The Åland Islands Question (On the Merits) (1921) Report by the Commission of Rapporteurs, League of Nations Council Document B7 21/68/106.

Barcelona Traction, Light and Power Company, Limited (Belgium v Spain) (Second Phase) (Judgments, Advisory Opinions and Orders) [1970] ICJ Rep 3.

Conference on Yugoslavia Arbitration Commission: Opinions on Questions Arising from the Dissolution of Yugoslavia [1992] 31 ILM 1494 [Badinter Commission on Yugoslavia].

Corfu Channel (Merits) [1949] ICJ Rep 4.

Customs Régime between German and Austria (Advisory Opinion) (1931) PCIJ (series A/B) No 41.

Deutsche Continental Gas-Gesellshaft v Polish State (1929) 5 ILR 11.

East Timor (Portugal v Australia) (Judgment) [1995] ICJ Rep 90 [East Timor].

The effect of reservations on the entry into force of the American Convention on Human Rights (arts. 74 and 75) (Advisory Opinion) (1982) IACHR, OC-2/92, Series A, No 2.

Free City of Danzig and International Labour Organization (Advisory Opinion) (1930) PCIJ (series B) No 18. 
Gillot et al v France (Communication) (2000) HRC CCPR/C/75/D/932/2000.

Government of the State of Eritrea $v$ Government of the Republic of Yemen (Phase One: Territorial Sovereignty and Scope of the Dispute) [1998] 114 ILR 1.

In the matter of the South China Sea Arbitration (Republic of the Philippines v People's Republic of China) (Award) [2016] PCA Case No 2013-19 [South China Sea Arbitration].

In re Duchy of Sealand (Administrative Court of Cologne, Germany) [1978] 80 ILR (1989) 683 [Duchy of Sealand].

The Independent Commission on Kosovo The Kosovo Report: Conflict, International Response, Lessons Learned (Oxford University Press, Oxford, 2000) [The Kosovo Report].

Island of Palmas case (The Netherlands v USA) (Award) PCA 23 January 1928 (1928) 2 RIAA 829.

Legal Consequences of the Construction of a Wall in the Occupied Palestinian Territory (Advisory Opinion) [2004] ICJ Rep 136 [Israeli Wall advisory opinion].

Legal consequences of the separation of the Chagos Archipelago from Mauritius in 1965 (Advisory Opinion) [2019] General List No. 169, 25 February 2019 [Chagos Archipelago].

Legal consequences for States of the continued presence of South Africa in Namibia (South West Africa) Notwithstanding Security Council Resolution 276 (1970) (Advisory Opinion) [1971] ICJ Rep 16 [Namibia advisory opinion].

Legal Status of Eastern Greenland (Judgements, Orders and Advisory Opinions) (1933) PCIJ 53, Series A/B.

Legality of the Threat of Nuclear Weapons (Advisory Opinion) [1996] ICJ Rep 226 [Nuclear Weapons].

Loizidou v Turkey (Merits) (1996) VI ECHR Reports 2216, 108 ILR.

Maritime Delimitation in the Area between Greenland and Jan Mayen (Denmark $v$ Norway) (Judgment) [1993] ICJ Rep 38.

Military and Paramilitary Activities in and against Nicaragua (Nicaragua v United States) (Merits) [1986] ICJ Rep 14 [Nicaragua].

North Sea Continental Shelf Cases (Germany v Denmark; Germany v Netherlands) (Judgment) [1969] ICJ Rep 3.

Petition to the Inter American Commission on Human Rights Seeking Relief from Violations Resulting from Global Warming Caused by Acts and Omissions by the United States (7 December 2005).

Questions of Mutual Assistance (Djibouti v France) (Judgment) [2008] ICJ Rep 177.

"Report of the International Committee of Jurists entrusted by the Council of the League of Nations with the task of giving an advisory opinion upon the legal aspects of the Åland Islands Question" Official Journal of the League of Nations, Supplement No. 3 (October 1920). 
Rights of Nationals of the United States of America in Morocco (France v United States of America) (Judgment) [1952] ICJ Rep 174.

South-West Africa Cases (Ethiopia v South Africa; Liberia v South Africa) (Preliminary Objections) [1962] ICJ Reports 319.

South-West Africa Cases (Ethiopia v South Africa; Liberia v South Africa) (Second Phase) [1966] ICJ Reports 6.

The S.S. "Wimbledon" (The Governments of His Britannic Majesty, and Others $v$ The German Empire) (Judgment) (1923) PCIJ (series A).

Sovereignty over Pedra Branca/Pulau Batu Puteh, Middle Rocks and South Ledge (Malaysia v Singapore) (Judgment) [2008] ICJ Rep 12.

Tinoco Claims Arbitration (Great Britain v Costa Rica) (Arbitral Awards) (1923) 1 UN Rep Intl Arb Awards 369.

Western Sahara (Advisory Opinion) [1975] ICJ Rep 12.

2. Domestic Jurisdictions

AF (Kiribati) [2013] NZIPT 800413.

Boumediene v Bush 553 US 723 (2009).

Burgard v Mair (1916) Tribunal Civil de Saint Etienne, 7 June 1916, reported 1917, as summarised in "Current Decisions" (1918) XXVII(4) Yale L J 574.

Mohd Salim v State of Uttarakhand \& others [2017] WPPIL 126/2014 (High Court of Uttarakhand, India).

Reference re Secession of Quebec [1998] 2 SCR 217.

Tavita v Minister of Immigration [1994] 2 NZLR 257.

Teitiota $v$ Chief Executive of the Ministry of Business Innovation and Employment [2013] NZHC 3125, CIV-2013-404-3528. 


\section{Secondary Sources}

\section{A. International and Regional Organisations' and their Organs' Declarations,} Resolutions, Reports, Online Resources, Media Releases, Speeches and other Documents

Ad Hoc Working Group on the Durban Platform for Enhanced Action Work of the Contact Group on item 3: (Negotiating text: Advance unedited version, 12 February 2015).

African Union "Member State Profiles" <www.au.int>.

The Alma-Ata Declaration (21 December 1991).

Amatuku Declaration on Climate Change and Oceans 8th Polynesian Leaders Group Meeting (29 June 2018) [Amatuku Declaration].

Asian Development Bank A Region at Risk: The Human Dimensions of Climate Change in Asia and the Pacific (Asian Development Bank, 2017).

Boe Declaration on Regional Security, adopted by the Pacific Island Leaders Forum, Boe, Nauru, 5 September 2018.

Charter of the Commonwealth 2013.

Climate change and its possible security implications GA Res 63/281, A/Res/63/281 (2009) [Resolution 63/281].

The Commonwealth "Maldives: History" <www.thecommonwealth.org>.

The Commonwealth "Member countries" <www.thecommonwealth.org>.

Commonwealth Network "Good Offices for Peace" <www.commonwealthofnations.org>.

COP23 Fiji "How is Fiji Affected by Climate Change" <wwww.cop23.com.fj>.

Council Decision (EU) 2016/590 of 11 April 2016 on the signing, on behalf of the European Union, the Paris Agreement adopted under the United Nations Framework Convention on Climate Change L 103/1.

Declaration on Principles of International Law concerning Friendly Relations and Cooperation among States in accordance with the Charter of the United Nations GA Res 2625, XXV (1970) [Friendly Relations Declaration].

Declaration on the granting of independence to colonial countries and peoples GA Res 1514 (XV) (1960) [Resolution 1514].

Declaration on the "Guidelines on the Recognition of New States in Eastern Europe and in the Soviet Union" (1992) 31 ILM 1485.

Declaration on the Inadmissibility of Intervention in the Domestic Affairs of States and the Protection of Their Independence and Sovereignty GA Res 2131, XX, A/Res/20/2131 (1965) [Resolution 2131]. 
Draft articles on Responsibility of States for Internationally Wrongful Acts, with commentaries [2001] vol II, pt 2 YILC 30 [Draft articles on State Responsibility].

Essam El-Hinnawi Environmental Refugees (UNEP, 1985).

European Committee of the Regions "Division of Powers: Bosnia and Herzegovina" <cor.europa.eu>.

Factors which should be taken into account in deciding whether a Territory is or is not a Territory whose people have not yet attained a full measure of selfgovernment GA Res 742, VIII (1953).

Follow-up to and implementation of the Mauritius Strategy for the Further Implementation of the Programme of Action for the Sustainable Development of Small Island States GA Res 63/213, A/Res/63/213 (2009).

The Frameworkfor Pacific Regionalism (Pacific Islands Forum Secretariat, Suva, July 2014).

Framework for Resilient Development in the Pacific: An Integrated Approach to Address Climate Change and Disaster Risk Management (FRDP) 2017-2030 (Pacific Islands Forum, 11 September 2016) [FRDP].

Maumoon Abdul Gayoom, President of the Republic of Maldives "Address to the United Nations General Assembly" (42nd Session of the United Nations General Assembly on the Special Debate on Environment and Development, United Nations Headquarters, New York, 19 October 1987).

Michael B Gerrard "The Role of Climate Change as a Threat Multiplier for Global Security" (Statement to the Security Council Open Arria Formula Meeting, 30 June 2015).

Global Compact for Safe, Orderly and Regular Migration (Internationally Negotiated and Agreed Outcome, 13 July 2018) [Global Compact for Migration].

Global Compact on Refugees A/73/12 (Part II) (2018).

Green Climate Fund <www.greenclimate.fund $>$.

High Ambition Coalition "Statement on Stepping Up Climate Ambition" (press release, 12 December 2018).

High-level Panel on Threats, Challenges and Change A More Secure World: Our Shared Responsibility: Report of the High-level Panel on Threats, Challenges and Change $\mathrm{A} / 59 / 565$ (2004).

Human Rights Committee General Comment No. 12: Article 1 (Right to selfdetermination) in Human Rights Instruments: Volume I: Compilation of General Comments and General Recommendations Adopted by Human Rights Treaty Bodies HRI/GEN/1/Rev.1 (Vol I) (2008) 172 [General Comment 12].

Human Rights Committee General Comment Adopted by the Human Rights Committee under Article 4, Paragraph 4, of the International Covenant on Civil and Political Rights: Addendum: General comment No. 23(50) (art.27) CCPR/C/21/Rev.1/Add.5 (1994) [General Comment 23]. 
Human Rights Council Human rights and climate change HRC Res 10/4 (2009).

Human Rights Council Human rights and climate change A/HRC/35/L.32 (2017).

Human Rights Council Report of the Independent Expert on the issue of human rights obligations relating to the enjoyment of a safe, clean, healthy and sustainable environment, John H Knox A/HRC/22/43 (2012).

Human Rights Council Summary report of the Office of the United Nations High Commissioner for Human Rights on the outcome of the full-day discussion on specific themes relating to human rights and climate change A/HRC/29/19 (2015).

Human Rights Law Centre Torture and cruel treatment in Australia: Joint NGO report to the United Nations Committee Against Torture (October 2014).

ILA Committee on Baselines Under the International Law of the Sea Sofia Conference (2012): Baselines Under the International Law of the Sea (International Law Association, 2012) [ILA Baselines Committee].

ILA Committee on International Law and Sea Level Rise Johannesburg Conference 2016: Interim Report (International Law Association, 2016).

ILA Committee on International Law and Sea Level Rise "List of Committee Members" <www.ila-hq.org>.

ILA Committee on International Law and Sea Level Rise Minutes of the Intersessional Meeting, Lopud, Croatia, 15-16 September 2017 (Chair: Professor David Vidas (Norway) (International Law Association, 2017).

ILA Committee on International Law and Sea Level Rise Resolution 6/2018 (August 2018) annex ('Sydney Declaration of Principles on the Protection of Persons Displaced in the Context of Sea Level Rise') [Sydney Declaration].

ILA Committee on International Law and Sea Level Rise Sydney Conference (2018) (International Law Association, 2018).

ILC Fragmentation of International Law: Difficulties arising from the Diversification and Expansion of International Law [2006] vol 2, pt 2 YILC 175.

ILC Report of the International Law Commission on the work of its eighteenth session [1967] vol 2 YILC 172.

ILC Report of the International Law Commission on the work of its fortieth session [1988] vol 2, pt 2 YILC 1.

ILC Report of the International Law Commission: Seventieth session [2018] A/73/10, Annex B Sea-level rise in relation to international law.

Importance of the universal realization of the right of peoples to self-determination and of the speedy granting of independence to colonial countries and peoples for effective guarantee and observance of human rights GA Res 2955, XXVII (1972).

Importance of the universal realization of the right of peoples to self-determination and of the speedy granting of independence to colonial countries and peoples 
for the effective guarantee and observance of human rights GA Res 37/43, A/Res/37/43 (1982).

Integrated economic development and commercial agreements GA Res 523, VI (1952).

International Commission of Jurists The Events in East Pakistan, 1971: A Legal Study by the Secretariat of the International Commission of Jurists (Geneva, 1972).

International Commission on Intervention and State Sovereignty The Responsibility to Protect (December 2001).

International Strategy for Disaster Risk Reduction GA Res 60/195, A/Res/60/195 (2005).

IOM "Climate Change and Migration Project Launched to Protect, Empower Pacific Communities" (press release, 26 March 2019).

IOM Global Migration Indicators 2018: Insights from the Global Migration Data Portal: www.migrationdataportal.org (Global Migration Data Analysis Centre and International Organization for Migration, Berlin, 2018).

IOM "Training Workshops: Capacity-building Activities on Migration, Environment and Climate Change" <environmentalmigration.iom.int>.

IOM "Who is a migrant?" International Organization for Migration <www.iom.int>.

IOM World Migration 2005: Costs and Benefits of International Migration (International Organization for Migration, Geneva, 2005).

IOM "World Migration Report 2015: Migrants and Cities: New Partnerships to Manage Mobility" (International Organization for Migration, Geneva, 2015).

IPCC Global Warming of $1.5^{\circ}$ C: an IPCC special report (IPCC, October 2018).

IPCC Global Warming of $1.5^{\circ} \mathrm{C}$ : an IPCC special report: Summary for Policymakers (IPCC, October 2018).

Florence Jaumotte, Ksenia Koloskova and Sweta C Saxena "This is the impact of migration on productivity" (31 January 2017) World Economic Forum <www.weforum.org>.

Juan E Méndez Report of the Special Rapporteur on torture and other cruel, inhuman or degrading treatment or punishment A/HRC/28/68/Add.1 (2015).

New York Declaration for Refugees and Migrants GA Res 71/1, A/RES/71/1 (2016).

Non-interference in the internal affairs of States GA Res 31/91 (1976).

Niue Declaration on Climate Change, Annex B to Forum Communique, 39th Pacific Islands Forum, Alofi, Niue, 19-20 August 2008, Doc PIFS(08)6.

OCHA Guiding Principles on Internal Displacement E/CN.4/1998/53/Add.2 (1998).

OECD States of Fragility 2016: Understanding Violence (OECD Publishing, Paris, 2016).

OECD States of Fragility 2018 (OECD Publishing, Paris, 2018). 
OECD and the World Bank Climate and Disaster Resilience Financing in Small Island Developing States (OECD and the World Bank, Washington DC, 2016)

OHCHR Applying a Human Rights-Based Approach to Climate Change Negotiations, Policies and Measures (Information Note, 2010).

OHCHR "Council discusses measures that can be adopted by States in addressing the effects of climate change on Human Rights" (press release, 6 March 2015)

OHCHR "Human Rights and Climate Change" <www.ohchr.org>.

OHCHR Report of the Office of the United Nations High Commissioner for Human Rights on the relationship between climate change and human rights A/HRC/10/61 (2009).

OHCHR Report of the Special Rapporteur on the human rights of migrants A/67/299 (2012).

OHCHR Understanding Human Rights and Climate Change (Office of the United Nations High Commissioner for Human Rights, Submission to the 21st Conference of the Parties to the United Nations Framework Convention on Climate Change, November 2015).

Organisation for Security and Co-operation in Europe (OSCE) Conference on Security and Co-operation in Europe (CSCE): Final Act of Helsinki (1 August 1975) [Helsinki Final Act].

Pacific Islands Forum Secretariat "The Pacific Islands Forum" <www.forumsec.org>.

Pacific Islands Forum Secretariat "Regional Policy Consultations - Boe Declaration Action Plan" (February 2019), available at 〈www.forumsec.org〉.

Pacific Small Island Developing States "Climate Action Statement by the Leaders of the Pacific Small Island Developing States" (5 July 2017).

Flavia Pansieri, United Nations Deputy High Commissioner for Human Rights "Address to the Full-Day Discussion on Human Rights and Climate Change" (Full-Day Discussion on Human Rights and Climate Change, Palais des Nations, Geneva, 6 March 2015).

Susin Park Climate Change and the Risk of Statelessness: The Situation of Low-lying Island States (United Nations High Commissioner for Refugees, Legal and Protection Policy Research Series, May 2011).

Participation of the Holy See in the work of the United Nations GA Res 58/314, A/RES/58/314 (2004).

Permanent Mission of Spain to the United Nations New York and Permanent Mission of Malaysia to the United Nations Open Arria-formula meeting on the role of Climate Change as a threat multiplier for Global Security: Concept Note (30 June 2015).

Permanent sovereignty over natural resources GA Res 1803 (XVII) (1962) [Resolution 1803]. 
Principles which should guide Members in deciding whether or not an obligation exists to transmit the information called for in Article 73e of the Charter GA Res 1541, XV (1960).

Question of American Samoa, Bahamas, Bermuda, British Virgin Islands, Brunei, Cavman Islands, Cocos (Kealing) Islands, Gilbert and Ellice Islands, Guam, Montserrat, New Hebrides, Pitcairn, St. Helena, Seychelles, Solomon Islands, Turks and Caicos Islands and the United States Virgin Islands GA Res 2869 (XXVI) (1971).

Question of the disposal of the former Italian colonies GA Res 289, IV(C) (1949) [Resolution 249].

Question of Palestine GA Res 3236, XXIX (1974).

Question of Palestine GA Res 34/65 (1979).

Question of Tokelau GA Res 71/107, A/Res/71/107 (2016).

Recommendations concerning international respect for the right of peoples and nations to self-determination GA Res 1314 (XIII) (1958).

Report of the Committee on the Elimination of Racial Discrimination A/51/18 (1996) annex III ('General Recommendation XXI (48), adopted at the 1147th meeting, on 8 March 1996') [General Comment 21].

Report of the Independent Expert on the right of peoples and individuals to international solidarity A/HRC/26/34 (2014).

Report of the Independent Expert on the right of peoples and individuals to international solidarity A/HRC/26/34 (2014) annex ("Proposed draft declaration on the right of peoples and individuals to international solidarity").

Report of the Special Rapporteur on the issue of human rights obligations relating to the enjoyment of a safe, clean, healthy and sustainable environment $\mathrm{A} / \mathrm{HRC} / 31 / 52$ (2016).

Report of the United Nations Conference on Environment and Development (Rio de Janeiro, 3-14 June 1992) A/Conf.151/26 (Vol 1) (1992) Annex I: Rio Declaration on Environment and Development.

Resolution 384 SC Res 384 (1975).

Resolution 2444 SC Res 2444, SC/Res/2444 (2018).

Right to exploit freely natural wealth and resources GA Res 626 (VII) (1952).

The right of the Palestinian people to self-determination GA Res 58/163, A/RES/58/163 (2004).

The right of peoples and nations to self-determination GA Res 637, VII (1952) [Resolution 637].

Security Council resolution 389, S/RES/389 (1976) [the question of East Timor].

Saufatu Sopoanga, Prime Minister of Tuvalu "Statement by the Honourable Saufatu Sopoanga OBE, Prime Minister and Minister of Foreign Affair of Tuvalu at the 58th General Assembly" (24 September 2003). 
Southern Rhodesia SC Res 460 (1979).

SPC "Atoll nations unite against the exceptional and existential threat caused by climate change" (15 May 2019) <www.spc.int>.

Special Report of the United Nations Visiting Mission to the Trust Territories of Togoland under British Administration and Togoland under French Administration, 1955 UN Doc T/1218 (1955).

Task Force on Displacement Report of the Task Force on Displacement (September 2018).

Task Force on Displacement "Task Force on Displacement Stakeholder Meeting: Recommendations for integrated approaches to avert, minimize and address displacement related to the adverse effects of climate change" (Meeting Report, Bogis-Bossey, Switzerland, 14-15 May 2018) in Task Force on Displacement Report of the Task Force on Displacement (16 September 2018) Annex VI, 54.

Task Force on Displacement Workplan of the Task Force on Displacement; and see UNFCCC Secretariat "Migration, displacement and human mobility" <www.unfccc.int>.

Laura Thompson, Deputy Director General of the International Organization for Migration "A World on the Move: The Benefits of Migration" (Brussels, 25 September 2014).

Dire Tladi Third report on peremptory norms of general international law (jus cogens) by Dire Tladi, Special Rapporteur A/CN.4/714 (2018).

Transforming our world: the 2030 Agenda for Sustainable Development GA Res A/Res/70/1 (2015) [Sustainable Development Goals].

United Nations Declaration on the Rights of Indigenous Peoples GA Res 618/295, A/Res/61/295 (2007).

United Nations A Human Rights-Based Approach Toolkit: Document B: The HRBA and the Basic Project Cycle: The Four Steps (United Nations Viet Nam).

United Nations A Human Rights-Based Approach Toolkit: Document E: Your HRBA Checklist (United Nations Viet Nam).

United Nations "About Permanent Observers" <www.un.org>.

United Nations Climate Change Greatest Threat to Small Island States, Delegate Tells Second Committee, Urging Critical International Support for Survival: SixtyEighth General Assembly: Second Committee: Panel Discussion (AM) (meeting report, GA/EF/3381, 1 November 2013).

United Nations Documents of the United Nations Conference on International Organization, Volume XVIII (UNIO/VOL.18, 1954).

United Nations "General Assembly Endorses First-Ever Global Compact on Migration, Urging Cooperation among Member States in Protecting Migrants" (19 December 2018) <www.un.org>.

United Nations General Assembly Seventy-Third Session: 55th plenary meeting, Monday 17 December 2018 (2018) A/73/PV.55. 
United Nations "Iceland" UN Data: A World of Information <www.data.un.org>.

United Nations "International Migrants Day 18 December" <www.un.org>.

United Nations International Migration Report 2015 ST/ESA/SER.A/384 (September 2016).

United Nations "Maldives" UN Data: A World of Information <www.data.un.org>.

United Nations "Maritime Space: Maritime Zones and Maritime Delimitation" (15 February 2011) <www.un.org>.

United Nations "Member States" <www.un.org>.

United Nations Minority Rights: International Standards and Guidance for Implementation (HR/Pub/10/3, 2010).

United Nations "Non-member States" <www.un.org>.

United Nations Sendai Framework for Disaster Risk Reduction 2015-2030 (United Nations Office for Disaster Risk Reduction, Geneva, UNISDR/GE/2015, 2015).

United Nations "The United Nations and Decolonization: Non-Self-Governing Territories" <www.un.org>.

United Nations "UN welcomes South Sudan as 193rd Member State" (press release, 14 July 2011).

United Nations "United Nations Treaty Series Online" <treaties.un.org>.

UNCTAD The Least Developed Countries Report 2016: The Path to Graduation and Beyond - Making the Most of the Process UNCTAD/LDC/2016/Corr.1 (2016).

United Nations Development Group "UN Practitioners' Portal on Human Rights Based Approaches to Programming" <www.hrbaportal.org>.

United Nations Development Group "How do human rights standards relate to the development programming process?" United Nations Practitioners' Portal on Human Rights Based Approaches to Programming <hrbaportal.org>.

UNDP Papua New Guinea "Creating partnerships crucial in lead up to independence referendum" (press release, 7 April 2018).

UNESCAP "Pacific Climate Change and Migration Project" <www.unescap.org>.

UNESCO International Meeting of Experts on further study of the concept of the rights of peoples: UNESCO, Paris, 27-30 November 1989: Final Report and Recommendations SHS-89/CONF.602/7 (1990).

UNESCO "Member States List" <www.unesco.org>.

UNFCCC Report of the Conference of the Parties on its Seventh Session, held at Marrakesh from 29 October to 10 November 2001 FCCC/CP/13/Add.1 (2002), Decision 5/CP.7, Implementation of Article 4, paragraphs 8 and 9, of the Convention (decision 3/CP.3 and Article 2, paragraph 3, and Article 3, paragraph 14, of the Kyoto Protocol) 
UNFCCC Report of the Conference of the Parties on its Seventh Session, held at Marrakesh from 29 October to 10 November 2001 FCCC/CP/13/Add.1 (2002), Decision 10/CP.7, Funding under the Kyoto Protocol.

UNFCCC Non-economic losses in the context of the work programme on loss and damage: Technical paper FCCC/TP/2013/2 (2013).

UNFCCC Report of the Conference of the Parties on its sixteenth session, held in Cancun from 29 November to 10 December 2010 FCCC/CP/2010/7/Add.1 (2011), Decision 1/CP.16, The Cancun Agreements: Outcome of the work of the Ad Hoc Working Group on Long-term Cooperative Action under the Convention [Cancun Adaptation Framework].

UNFCCC Report of the Conference of the Parties on its eighteenth session, held in Doha from 26 November to 8 December 2012, FCCC/CP/2012/8/Add.1 (2013), Decision 3/CP.18, Approaches to address loss and damage associated with climate change impacts in developing countries that are particularly vulnerable to the adverse effects of climate change to enhance adaptive capacity [Approaches to Loss and Damage].

UNFCCC Report of the Conference of the Parties on its nineteenth session, held in Warsaw from 11 to 23 November 2013 FCCC/CP/2013/Add.1 (2014), Decision 2/CP.19, Warsaw international mechanism for loss and damage associated with climate change impacts [Warsaw Mechanism].

UNFCCC Report of the Conference of the Parties on its twenty-first session, held in Paris from 30 November to 13 December 2015 FCCC/CP/2015/10/Add.1 (2015), Decision 1/CP.21, Adoption of the Paris Agreement.

UNFCCC Executive Committee of the Warsaw International Mechanism for Loss and Damage Letter from the UNFCCC Executive Committee of the Warsaw International Mechanism for Loss and Damage associated with Climate Change Impacts inviting organisations and experts to provide knowledge, data and scientific information on climate change-related internal and cross-border migration (ref EXCOM/MK/cma, 30 March 2016).

UNFCCC Executive Committee of the Warsaw International Mechanism on Loss and Damage Report of the Executive Committee of the Warsaw International Mechanism for Loss and Damage associated with Climate Change Impacts FCCC/SB/2016/3 (2016).

UNFCCC Executive Committee of the Warsaw International Mechanism on Loss and Damage Report of the Executive Committee of the Warsaw International Mechanism for Loss and Damage associated with Climate Change Impacts: Draft decision -/CP.23 FCCC/SB/2017/L.5 (2017).

UNFCCC Executive Committee of the Warsaw International Mechanism for Loss and Damage Technical Meeting: Action Area 6: Migration, Displacement and Human Mobility: Synthesis of relevant information, good practices and lessons learned in relation to Pillar 1: Enhancing Knowledge and Understanding (Casablanca, July 2016). 
UNFCCC Least Developed Country Expert Group National Adaptation Plans: Technical guidelines for the national adaptation plan process (UNFCCC Secretariat, December 2012).

UNFCCC Secretariat "Executive Committee of the Warsaw International Mechanism for Loss and Damage" United Nations Framework Convention on Climate Change <www.unfecc.int $>$.

UNFCCC Secretariat "Focus: Adaptation" United Nations Framework Convention on Climate Change <www.unfecc.int>.

UNFCCC Secretariat "Focus: Climate Finance" United Nations Framework Convention on Climate Change <www.unfccc.int>.

UNFCCC Secretariat "Submissions on internal and cross-border migration, displacement and other forms of human mobility" <www.unfccc.int>.

UNFCCC Secretariat "What are Bodies?" <www.unfccc.int>.

UN Free \& Equal "Information Sheet: Frequently Asked Questions: Sexual orientation, gender identity and intersex status in the Pacific".

UNGA "Tuvalu: H. E. Mr Enele Sosene Sopoaga, Prime Minister: Statement Summary" (27 September 2018) <gadebate.un.org>.

UNHCR A Toolbox: Planning Relocations to Protect People from Disasters and Environmental Change (Brookings Institute, Georgetown University and UNHCR, 2017) .

UNHCR Climate Change and Statelessness: An Overview (United Nations High Commissioner for Refugees, submission to the 6th session of the Ad Hoc Working Group on Long-Term Cooperative Action (AWG-LCA 6) under the UNFCCC, 1 to 2 June 2009, Bonn, Germany, May 2009).

UNHCR Guidance on Protecting People from Disasters and Environmental Change through Planned Relocation (Brookings, Georgetown University and UNHCR, 7 October 2015) [Guidance on Planned Relocation].

UNHCR Summary of Deliberations on Climate Change and Displacement (United Nations High Commissioner for Refugees, April 2011).

UN News Centre "Climate change 'threatens self-determination' of citizens in island States, UN rights council told" (6 March 2015) <www.un.org>.

UN News "UN chief calls for 'enlightened self-interest' from world leaders to save 'the whole planet' from climate change" (18 May 2019) <news.un.org>.

United Nations Permanent Forum on Indigenous Issues Climate change and indigenous peoples (backgrounder).

United Nations Population Fund A Human Rights-Based Approach to Programming: Practical Implementation Manual and Training Materials (UNFPA, 2010).

UN Refugees and Migrants "Global compact for migration" <refugeesmigrants.un.org>.

UNSC Maintenance of International Peace and Security S/PV.7499 (30 July 2015). 
UNSC "Security Council Meeting 8307th Meeting (AM) SC/13417: Addressing Security Council, Pacific Island President Calls Climate Change Defining Issue of Next Century, Calls for Special Representative on Issue" (11 July 2018) United Nations <www.un.org>.

UNSC "Somalia has not been abandoned by international community, say speakers in Security Council" (press release, SC/6194, 15 March 1996, statements of the Representatives of the Republic of Korea and Botswana).

UNSC Statement by the President of the Security Council S/PRST/2011/15* (2011).

UNSG Climate change and its possible security implications: Report of the SecretaryGeneral A/64/350 (2009).

UN Women Climate Change and Migration in Bangladesh: A Gender Perspective (2015).

UN WomenWatch Women, Gender Equality and Climate Change (factsheet, 2009).

Peter Ventevogel and others Mental Health and Psychological Support for Refugees, Asylum Seekers and Migrants on the Move in Europe: A Multi-Agency Guidance Note (United Nations High Commissioner for Refugees, IOM and the MHPSS Network, December 2015).

Woodrow Wilson, President of the United States of America "War Aims of Germany and Austria" (11 February 1918) in Ray Stannard Baker and William E Dodd (eds) The Public Papers of Woodrow Wilson: War and Peace Presidential Messages, Addresses and Public Papers (1917-1924) (Harper \& Brothers, 1927).

Woodrow Wilson, President of the United States of America "President Woodrow Wilson's Fourteen Points: 8 January 1918" (Woodrow Wilson's Fourteen Points), available at Yale Law School, The Avalon Project: Documents in Law, History and Diplomacy <avalon.law.yale.edu>.

World Bank "Member Countries" <www.worldbank.org>.

World Commission on Environment and Development Report of the World Commission on Environment and Development: Our Common Future (United Nations, 20 March 1987).

World Health Organization "Countries" <www.who.int>.

World Health Organization "Climate change and health " (1 February 2018) <www.who.int>.

The World Bank "World Bank Open Data: Population, total" <data.worldbank.org>.

'Written Statement of the African Union' Legal Consequences of the Separation, Chagos Archipelago (Advisory Opinion) [2019] ICJ Written Proceedings. 


\section{B. Journal Articles and Research Papers}

Yasmin Abdullah "The Holy See at United Nations Conferences: State or Church" (1996) 96(7) Colum.L.Rev. 1835.

W. Neil Adger and others "Human Security" in Christopher B Field and others (eds) Climate Change 2014: Impacts, Adaptation, and Vulnerability: Part A: Global and Sectoral Aspects: Working Group II Contribution to the Fifth Assessment Report of the Intergovernmental Panel on Climate Change (Cambridge University Press, New York, 2014) Chapter 12, 755.

Royce Anderson "A Definition of Peace" (2004) 10(2) Peace and Conflict: Journal of Peace Psychology 101.

A H Angelo "The Niue Constitution" (2009) 15 Revue Juridique Polynésienne 157.

Alex Ansong "The Concept of Sovereign Equality of States in International Law" (2018) II(1) Gimpa Law Review 13.

The Application of the United Nations Charter to Domestic Law (1951) 20(1) Fordham L Rev 91.

Frederick A Armah and others "Food security and climate change in drought-sensitive savanna zones of Ghana" (2011) 16(3) Migration and Adaptation Strategies for Global Change 291.

Sumudu Atapattu "Climate Change, Human Rights, and Forced Migration: Implications for International Law" 27 Wisconsin Int'1 L J 607, 2009-2010.

Halvard Bahaug "Climate-conflict research: some reflections on the way forward" (2015) 6 WIREs Climate Change 269.

Ayelet Banai "Self-Determination and Resource Rights: In Defence of Territorial Jurisdiction Over Natural Resources" (2016) 22(1) Res Publica 9.

Vincent P Bantz "The International Legal Status of Condominia" (1998) 12 Florida Journal of International Law 77.

Jon Barnett and W. Neil Adger, "Climate Dangers and Atoll Counties" (2003) 61 Climatic Change 321.

Jane B Baron "Rescuing the Bundle-of-Rights Metaphor in Public Law" (2014) 82(1) UCin LR 57.

Vicente R Barros and others (eds) Climate Change 2014: Impacts, Adaptation, and Vulnerability: Part B: Regional Aspects: Working Group II Contribution to the Fifth Assessment Report of the Intergovernmental Panel on Climate change (Cambridge University Press, Cambridge, 2014) [IPCC WGII AR5].

Marc Beaulieu "Tuvaluan Faatele: A Performative and Historico-geographic Context" (2009) 34 Context 49.

Roberto Belloni "Peacebuilding and Consociational Electoral Engineering in Bosnia and Herzegovina" (2004) 11(2) International Peacekeeping 334. 
Samantha Besson "The Authority of International Law - Lifting the Veil" (2009) 31 Sydney Law Review 343.

Dinesh Bhugra and Matthew A Becker "Migration, cultural bereavement and cultural identity" (2005) 4(1) World Psychiatry 18.

Florian Bieber "Is Nationalism on the Rise? Assessing Global Trends" (2018) 17(5) Ethnopolitics 519.

Frank Biermann and Ingrid Boas "Preparing for a Warmer World: Towards a Global Governance System to Protect Climate Refugees" (2010) 10(1) Global Environmental Politics 60.

Lea Brilmayer and Natalie Klein "Land and Sea: Two Sovereignty Regimes in Search for a Common Denominator" (2001) 33 NYU J Int'l Law \& Pol. 703.

Lea Brilmayer "Secession and Self-Determination: A Territorial Interpretation" (1991) 16 Yale J Int Law 177.

Robin Bronen "Climate-induced community relocations: using integrated socialecological assessments to foster adaptation and resilience" (2015) 20(3) Ecology and Society 36.

Ian Brownlie "Recognition in Theory and Practice" (1982) 53(1) BYBIL 197.

Ian Brownlie "The Rights of Peoples in Modern International Law" (1985) 19(2) Bulletin of the Australian Society of Legal Philosophy 104.

Allan E Buchanan "The Right to Self-Determination: Analytical and Moral Foundations" (1991) 8(2) Ariz J Int'1 Comp L 41.

Allen Buchanan "Self-Determination, Revolution and Intervention" (2016) 126(2) Ethics 447.

Maxine Burkett "The Nation Ex-Situ: On climate change, deterritorialized nationhood and the post-climate era" (2011) 2 Climate Law 345.

Heriberto Cairo "The Duty of the Benevolent Master: From Sovereignty to Suzerainty and the Biopolitics of Intervention" (2006) 31 Alternatives 285.

Cenap Çakmak "Civil Society Actors in International Law and World Politics: Definition, Conceptual Framework, Problems" (2008) 7 Int'l J Civ Soc'y L 6.

Antonio Cassese "Remarks on Scelle's Theory of 'Role Splitting' (dédoublement fonctionnel) in International Law" (1990) 1 EJIL 210.

BS Chimni "The Past, Present and Future of International Law: A Critical Third World Approach" (2007) Melb J Int'l Law 499.

John A Church and others "Sea Level Change" in Thomas F Stocker and others (eds) Climate Change 2013: The Physical Science Basis: Working Group 1 Contribution to the Fifth Assessment Report of the Intergovernmental Panel on Climate Change (Cambridge University Press, Cambridge, 2013) Chapter 13, 1137.

DL Corbitt "What is Liberal Cession of Western Territory?" (1926) 3(2) North Carolina Historical Review 372. 
Stephen Cornell "Process of Native Nationhood: The Indigenous Politics of SelfGovernment" (2015) 6(4) The International Indigenous Policy Journal) article 4.

Alberto Costi "Climate Change and the Legal Status of a Disappearing State in International Law" (2014) 12 International Law Readings (Voronezh State University) 140.

Noel Cox "The Continuing Question of Sovereignty and the Sovereign Military Order of Jerusalem, of Rhodes and of Malta" (2006) 13 Aust ILJ 211.

Matthew CR Craven "The Problem of State Succession and the Identity of States under International Law" (1998) 9 EJIL 142.

Anthony D'Amato "The Relation of Theories of Jurisprudence to International Politics and Law" (1970) 27 Wash \& Lee L Rev 257.

Sönke Dangendorf and others "Reassessment of 20th century global mean sea level rise" (2017) 114(23) PNAS 5946.

Robert M DeConto and David Pollard "Contribution of Antarctica to past and future sea-level rise" (2016) 531 Nature 591.

Ryan Delaney "De-recognition of States: A Different Approach to Failed States" (2008) Fall/Winter Standford Journal of International Relations 10.

Katerina Diamandaki "Virtual ethnicity and digital diasporas: Identity construction in cyberspace" (2003) 2(2) Global Media Journal 1.

Frank Dietrich and Joachim Wündisch "Territory Lost - Climate Change and the Violation of Self-Determination Rights" (2015) 2(1) Moral Philosophy and Politics 83.

Thomas J Doherty and Susan Clayton "The Psychological Effects of Global Climate Change" (2011) 64(4) American Psychologist 265.

Michel Dugas, Nina Laugesen and William M Bukowski "Intolerance of Uncertainty, Fear of Anxiety, and Adolescent Worry" (2012) 40 J Abnorm Child Psychol 863.

Julia B Edwards "The Logistics of Climate-Induced Relocation: Lessons from the Carteret Islands, Papua New Guinea" (2013) 32(3) Refugee Survey Quarterly 52.

Gareth Evans "Commonwealth Diplomacy and the End of Apartheid" (2017) 106(1) The Round Table 61.

Dana Zartner Falstrom "Stemming the Flow of Environmental Displacement: Creating a Convention to Protect Persons and Preserve the Environment" (2001) Colo J Int'l Env'l L \& Policy 1.

Carol Farbotko and Heather Lazrus "The first climate refugees? Contesting global narratives of climate change in Tuvalu" (2012) 22(2) Global Environmental Change 382.

Christopher B Field and others (eds) Climate Change 2014: Impacts, Adaptation, and Vulnerability: Part A: Global and Sectoral Aspects: Working Group II Contribution to the Fifth Assessment Report of the Intergovernmental Panel on Climate Change (Cambridge University Press, New York, 2014). 
Christopher B Field and others Summary for Policy Makers: Climate Change 2014: Impacts, Adaptation and Vulnerability: Part A: Global and Sectoral Aspects: Contribution of Working Group II to the Fifth Assessment Report of the Intergovernmental Panel on Climate Change (Cambridge University Press, Cambridge, 2014).

Thomas M Franck "The Emerging Right to Democratic Governance" (1992) 86 Am J Intl Law 46.

Will Frank "Climate Liability under Public International Law" (summary of the author's article in German, "Überlegungen zur Klimahaftung nach Völkerrecht" (2014) 33 Neue Zeitschrift für Verwaltungsrecht - Extra 1).

Duncan French "'You Will Always Have the Poor': A Reflection on the Paradox of Justice as Law" (2015) 22 International Journal on Minority and Group Rights 533.

Jessica G Fritz and others "Hope, despair and transformation: Climate change and the promotion of mental health and wellbeing" (2008) 2 Int'l J Mental Health Systems 13.

Denice Garcia "Warming to a Redefinition of International Security: The Consolidation of a Norm Concerning Climate Change" (2010) 24(3) International Relations 271.

Peter H Gleick "Water, Drought, Climate Change, and Conflict in Syria" (2014) 6 Weather, Climate and Security 331.

Thomas D Grant "Defining Statehood: The Montevideo Convention and its Discontents" (1999) 37 Colum J Transnat'l L 403.

Mariya Gromilova "Revisiting Planned Relocation as a Climate Change Adaptation Strategy: The Added Value of a Human Rights-Based Approach" (2014) 10(1) Utrecht Law Review 76.

Leo Gross "The Peace of Westphalia, 1648-1948" 42(1) AJIL 20.

Andrew T Guzman "Against Consent" (2012) Va J Int'l L 747.

Margaux J Hall and David C Weiss "Avoiding Adaptation Apartheid: Climate Change Adaptation and Human Rights Law" (2012) 37 YJIL 309.

James Hansen and others "Ice melt, sea level rise and superstorms: evidence from paleoclimate data, climate modeling, and modern observations that $2{ }^{\circ} \mathrm{C}$ global warming is highly dangerous" (2015) 15 ACPD 20059.

Hurst Hannum "Rethinking Self-Determination" (1993) 34 Va J Int'l L 1.

Chelsea Harvey "CO2 Emissions Reached an All-Time High in 2018" (6 December 2018) Scientific American <www.scientificamerican.com>.

Oona Hathaway "Between Power and Principle: An Integrated Theory of International Law" (2005) 72 University of Chicago Law Review 469.

Tricia Redeker Hepner "Generation Nationalism and Generation Asylum: Eritrean Migrants, the Global Diaspora, and the Transnational Nation-State" (2009) 18(1/2) Diaspora 184. 
Holger P Hestermeyer "Reality or Aspiration? Solidarity in International Environmental and World Trade Law" (Otto-Hahn-Gruppe "Diversität und Homogenität" Max-Planck-Institut für ausländisches öffentliches Recht und Völkerrecht, Outcome Paper 02/2012, 2012).

Richard S Hill "New Zealand Maori: The Quest for Indigenous Autonomy" (2016) 15(1) Ethnopolitics 144.

David Hodgkinson and others "The Hour When the Ship Comes In: A Convention for Persons Displaced by Climate Change" (2010) 36 Monash Univ L Rev 69.

Ove Hoegh-Guidberg and others "Impacts of $1.5^{\circ} \mathrm{C}$ global warming on natural and human systems" in IPCC Global Warming of $1.5^{\circ} \mathrm{C}$ : an IPCC special report (IPCC, October 2018), chapter 3.

Jacquetta M Holder and David Jolley "Forced relocation between nursing homes: residents' health outcomes and potential moderators" (2012) 22(4) Reviews in Clinical Gerontology 301.

Terry Hutchison and Nigel Duncan "Defining and Describing What We Do: Doctrinal Legal Research" (2012) 17(1) Deakin Law Review 83.

Iata Iata "Customary Land Rights and Pacific Islands Security \& Stability" (2018) 419 Asia Pacific Bulletin 1.

Abhimanyu George Jain "The 21st Century Atlantis: The International Law of Statehood and Climate Change-Induced Loss of Territory" (2014) 50(1) Stan J Int'l L 1.

Demelza Jones "Diaspora identification and long-distance nationalism among Tamil migrants of diverse state origins in the UK" (2014) 37(14) Ethnic and Racial Studies 2547.

Ricardo T Jose "Governments in Exile" 8(1-2) Asian and Pacific Migration Journal 179.

Juan Xi, Sean-Shong Hwang and Patricia Drentea "Experiencing a Forced Relocation at Different Stages of Life: The Effects of China's Three Gorges Project-induced Relocation on Depression" (2013) 3(1) Society and Mental Health 59.

Karol Karksi "The International Legal Status of the Sovereign Military Hospitaller Order of St. John of Jerusalem of Rhodes and of Malta" (2012) 14 International Community Law Review 19.

Alice Kaswan "Climate Adaptation and Theories of Justice" (University of San Francisco Law Research Paper 2016-01).

Paul S Kench, Murray R Ford and Susan D Owen "Patterns of island change and persistence offer alternate adaptation pathways for atoll nations" (2018) 9:605 Nature Communications 1.

Rachel Kendall "Climate Change as a Security Threat to Pacific Islands" (2012) 16 NZJEL 83.

Benedict Kingsbury "Self-Determination and 'Indigenous Peoples'" (1992) 86 Proceedings of the American Society of International Law 383. 
Brandon A Kohrt and Suzan J Song "Who benefits from psychosocial support interventions in humanitarian settings?" (2018) 6(4) The Lancet 354.

Jan Klabbers "Book Review: D. Raič Statehood and the Law of Self-Determination" (2004) 10 International Journal on Minority and Group Rights 163.

Jan Klabbers "The Right to be Taken Seriously: Self-Determination in International Law" [2006] 28 Human Rights Quarterly 186.

Jan Klabbers "Shrinking Self-Determination: The Chagos Opinion of the International Court of Justice" (2019) 8(2) ESIL Reflections.

Avery Kolers "Floating Provisos and Sinking Islands" (2012) 29(4) Journal of Applied Philosophy 333.

Stephen D Krasner "Recognition: organized hypocrisy once again" (2013) 5(1) International Theory: A Journal of International Politics, Law and Philosophy 170.

Stephen D Krasner "Rethinking the sovereign state model" (2001) 27 Review of International Studies 17.

Udayangani Kulatunga "Impact of Culture towards Disaster Risk Reduction" (2010) 14(4) International Journal of Strategic Property Management 304.

Soonchun Lee "Identity and Continuity of State: The Cases of the Baltic States and Korea" (2011) 10 Korean University Law Review 149.

Arend Lijphart "Consociational Democracy" (1969) 21(2) World Politics 207.

Matthew Lister "The Legitimating Role of Consent in International Law" (2011) 11(2) Chicago Journal of International Law 664.

Julia Lisztwan "Stability of Maritime Boundary Agreements" (2012) 37(1) Yale J Int'1 Law 153.

Justine T Locke "Climate change-induced migration in the Pacific region: sudden crisis and long-term developments" (2009) 175(3) The Geographical Journal 171.

Amy Maguire and Jeffrey McGee "A Universal Human Right to Shape Responses to a Global Problem? The Role of Self-Determination in Guiding the International Legal Response to Climate Change" (2017) 26(1) RECIEL 54.

Kurt Martens "The Position of the Holy See and Vatican City State in International Relations" 83 U Det Mercy L Rev 729.

Ian Martin and Alexander Mayer-Rieckh "The United Nations and East Timor: From Self-Determination to State Building" (2005) 12(1) International Peacekeeping 125.

Elizabeth Mavroudi "Nationalism, the Nation and Migration: Searching for Purity and Diversity" (2010) 14(3) Space and Polity 219.

Jane McAdam "'Disappearing States', Statelessness and the Boundaries of International Law" UNSW Law Research Paper No. 2010-2. 
Jane McAdam "Environmental Migration Governance" (2009) UNSW Law Research Paper 2009-1.

Jane McAdam "Lessons from planned relocation and resettlement in the past" (2015) 49 Forced Migration Review 30.

Jane McAdam "Swimming Against the Tide: Why a Climate Change Displacement Treaty is not the Answer" (2011) 23(1) International Journal of Refugee Law 2.

Jane McAdam and others International Law and Sea-Level Rise: Forced Migration and Human Rights (Fridtjof Nansens Institutt, University of New South Wales, and the Andrew and Renata Kaldor Centre for International Refugee Law, FNI Report 1/2016, January 2016).

Lachlan McIver and others "Assessment of Health Impacts of Climate Change in Kiribati" (2014) 11(5) Int. J. Environ. Res. Public Health 5224.

Michelle A McKinley "Conviviality, Cosmopolitan Citizenship, and Hospitality" (2009) 5 Unbound 55.

Campbell McLachlan "The Principle of Systemic Integration and Article 31(3)(C) of the Vienna Convention" (2005) 54 ILQC 279.

Robert McLeman, "Climate Change Migration, Refugee Protection, and Adaptive Capacity Building" (2008) 4 McGill Int'l J Sust Dev L \& Pol'y 1.

Kathleen McVay "Self-Determination in New Contexts: The Self-Determination of Refugees and Forced Migrants in International Law" (2012) 28(75) Merkourios 36.

Prabhakar Menon "Book Review: Claude Arpi, Tibet: The Last Months of a Free Nation: India Tibet Relations (1947-1962) Part I, (New Delhi, 2017, VIJ Books)" (2017) 12(4) Indian Foreign Affairs Journal 355.

Alex Mills "Rethinking Jurisdiction in International Law" (2014) 11(1) BYBIL 187.

Freddy D Mnyongani "Between a rock and a hard place: the right to self-determination versus uti possidetis in Africa" (2008) 41(3) Comp \& Intl LJ S Af 463.

Maureen F Mooney and others "Psychosocial Recovery from Disasters: A Framework Informed by Evidence" (2011) 40(4) New Zealand Journal of Psychology 26.

John R Morss "The International Legal Status of the Vatican/Holy See Complex" (2016) 26(4) EJIL 927.

Joanna Mossop "The South China Sea Arbitration and New Zealand's Maritime Claims" (2017) 15 NZJPIL 265.

Sean D Murphy "Democratic Legitimacy and the Recognition of States and Governments" (1999) 48(3) The International and Comparative Law Quarterly 545.

Boris Nieswand "Banal diasporic nationalism: Ghana@50 celebrations in Berlin" (2012) 35(11) Ethnic and Racial Studies 1874.

Cara Nine "Ecological Refugees, State Borders, and the Lockean Proviso" (2010) 27(4) Journal of Applied Philosophy 359. 
Fran H Norris and others "60,000 Disaster Victims Speak: Part I. An Empirical Review of the Empirical Literature, 1981-2001" (2002) 65(3) Psychiatry 207.

Leonard A Nurse and others "Small Islands" in Vicente R Barros and others (eds) Climate Change 2014: Impacts, Adaptation, and Vulnerability: Part B: Regional Aspects: Working Group II Contribution to the Fifth Assessment Report of the Intergovernmental Panel on Climate change (Cambridge University Press, Cambridge, 2014), Chapter 29, 1163.

Orit Nuttman-Shwartz, Rachel Dekel and Rivka Tuval-Mashiach "Post-Traumatic Stress and Growth following Forced Relocation" (2011) 41 British Journal of Social Work 486.

Jörgen Ödalen "Underwater Self-determination: Sea-level Rise and Deterritorialized Small Island States" (2014) 17(2) Ethics, Policy \& Environment 225

Izabela Olszewska "Cultural Identity of Citizens of Gdansk from an Ethnographic Perspective on the Basis of Chosen Texts of the Free City of Danzig" (2013) 2 Colloquia Humanistica 133.

Jouni Paavola and W Neil Adger "Fair adaptation to climate change" (2006) 56(4) Ecological Economics 594.

Jessica Palmer "Theories of the Trust and What They Might Mean for Beneficiary Rights to Information" (2010) NZLR 541.

Sophie Pascoe "Sailing the Waves on Our Own: Climate Change Migration, SelfDetermination and the Carteret Islands" (2015) 15(2) QUT Law Review 72.

David Pearson and Charles Sedgwick "The English Question in New Zealand: Exploring National Attachments and Detachments among English Migrants" (2010) 16 Nationalism and Ethnic Politics 44.

Nikita Perumal "'The places where I live is where I belong': community perspectives on climate change and climate-related migration in the Pacific island of Vanuatu" (2018) 13(1) Island Studies Journal 45.

Michael Alfred Peszke The British-Polish Agreement of August 1940: Its Antecedents, Significance, and Consequences (2011) 24 Journal of Slavic Military Studies 648.

Lavanya Rajamani "The 2015 Paris Agreement: Interplay Between Hard, Soft and Non-Obligations" (2016) 28 Journal of Environmental Law 337.

Rosemary Rayfuse "W(h)ither Tuvalu? International Law and Disappearing States" UNSW Law Research Paper No. 2009-9.

Rosemary Rayfuse "International Law and Disappearing States: Maritime Zones and the Criteria for Statehood" (2011) 41/6 Environmental Policy and Law 281.

Rosemary Rayfuse and Emily Crawford "Climate Change, Sovereignty and Statehood" (Sydney Law School, Legal Studies Research Paper No. 11/59, September 2011).

Mathias Risse "The Right to Relocation: Disappearing Island Nations and Common Ownership of the Earth" (2009) 23(3) Ethics and International Affairs 281. 
Richard Rosencrance "The Rise of the Virtual State" (1996) 75 Foreign Affairs 45.

Matthew Roskruge, Sandy Morrison and Te Kahautu Maxwell "Measuring the value of the contribution of Māori language and culture to the New Zealand economy" (Waikato University, March 2017).

Nathan Jon Ross "Climate Change Risks to Representative Government in Kiribati" (2014) 20 NZACL Yearbook/(2015) 21 CLJP/JDCP 91.

Nicole Roughan "The Association of State and Indigenous Law: A Case Study in 'Legal Association'" (2009) 59 UTLJ 135.

Charles Rousseau "L'Indepenance de l'Etat dans l'Ordre International" II (1948) Recueil des Cours Académie de Droit International de la Haye 171.

LS Rowe "The Significance of the Seventh International Conference of American States" (1934) 28 Proceedings of the American Society for International Law at its Annual Meeting (1921-1969) 34.

Cedric Ryngaert and Sven Sobrie "Recognition of States: International Law or Realpolitik? The Practice of Recognition in the Wake of Kosovo, South Ossetia, and Abkhazia" (2011) 24(2) LJIL 467.

David L Sam and John W Berry "Acculturation: When Individuals and Groups of Different Cultural Backgrounds Meet" (2010) 5(4) Perspectives on Psychological Science 472.

Sara Sanders, Stan L Bowie and Yvonne Dias Bowie "Lessons Learned on Forced Relocation of Older Adults: The Impact of Hurricane Andrew on Health, Mental Health, and Social Support of Public Housing Residents" (2004) 40(4) Journal of Gerontological Social Work 23.

Oscar Schachter "The Charter and the Constitution: The Human Rights Provisions in American Law" (1951) 4(3) Vand L Rev 643.

Oscar Schachter "The Relation of Law, Politics and Action at the United Nations" (1963) 109(II) Hague Recueil 169.

Carl-Friedrich Schleussner and others "Armed-conflict risks enhanced by climaterelated disasters in ethnically fractionalized countries" (2016) 113(33) PNAS 9216.

Gregory Shaffer "The New Legal Realist Approach to International Law" (2015) University of California Legal Studies Research Paper Series No. 2015-54.

Shawn Shen and Francois Gemenne "Contrasted Views on Environmental Change and Migration: the Case of Tuvaluan Migration to New Zealand" (2011) 49(S1) International Migration 224

Bruno Simma "From Bilateralism to Community Interest in International Law" (1994) 250 Recueil des Cours de l'Académie de Droit International 217.

Thomas W Simon "Remedial Secession: What the Law Should Have Done, From Katanga to Kosovo" (2011) 40 Ga J Int'l \& Comp L 105.

Zlatko Skrbiš, Loretta Baldassar and Scott Poynting "Negotiating Belonging: Migration and Generations" (2007) 28(3) Journal of Intercultural Studies 261. 
Anna Stilz "Nations, States and Territories" (2011) 121(3) Ethics 572.

Thomas F Stocker and others (eds) Climate Change 2013: The Physical Science Basis: Working Group 1 Contribution to the Fifth Assessment Report of the Intergovernmental Panel on Climate Change (Cambridge University Press, Cambridge, 2013) [IPCC WGI AR5].

Thomas F Stocker and others (eds) Summary for Policy Makers: Climate Change 2013: The Physical Science Basis: Working Group 1 Contribution to the Fifth Assessment Report of the Intergovernmental Panel on Climate Change (Cambridge University Press, Cambridge, 2013).

Thomas Michael Swensen "Of Subjection and Sovereignty: Alaska Native Corporations and Tribal Governments in the Twenty-First Century" (2015) 30(1) Wicazo Sa Review 100.

Celia A Taylor "The Modest Proposal: Statehood and Sovereignty in a Global Age" (1997) 18(3) U Pa J Int'1 Econ. L 745.

Paul Taylor "The United Nations in the 1990s: Prospective Cosmopolitanism and the Issue of Sovereignty" (1999) XLVII Political Studies 538.

Ole Magnus Theisen, Nils Petter Gleditsch and Halvard Bahaug "Is climate change a driver of armed conflict?" (2013) 117 Climate Change 613.

Daniel Thürer "The 'failed State' in international law" (1999) 81(836) International Review of the Red Cross 731.

Lori Uscher-Pines "Health effects of relocation following disaster: a systematic review the literature" (2009) 33(1) Disasters 1.

Milla Emilia Vaha "Drowning under: Small island states and the right to exist" (2015) 11(2) JIPT 206.

Milla Emilia Vaha "Hosting the Small Island Developing States: two scenarios" (2018) 10(2) International Journal of Climate Change Strategies and Management 229.

Jure Vidmar "Remedial Secession in International Law: Theory and (Lack of) Practice" (2010) 6(1) St Antony's International Review 37.

Nii Lante Wallace-Bruce "Of Collapsed, Dysfunctional and Disoriented States: Challenges to International Law" (2000) 47 NILR 53.

Nick Watts and others "Health and climate change: policy responses to protect public health" 386 The Lancet 1861 at 1877.

Marc Weller "The Self-Determination Trap" (2005) 4(1) Ethnopolitics 3.

Wouter G Werner and Jaap H de Wilde "The Endurance of Sovereignty" (2001) 7(3) European Journal of International Relations 283.

Caitlin E Werrell and Francesco Femia "Climate Change, the Erosion of State Sovereignty, and World Order" (2016) 22(2) Brown Journal of World Affairs 221.

Margaretha Wewerinke "A Right to Enjoy Culture in the Face of Climate Change: Implications for 'Climate Migrants'" (2013) CGHR Working Paper \#6 / 4CMR 
Working Paper \#7, Cambridge Centre for Climate Change Migration Research, University of Cambridge.

Susannah Willcox "Climate Change Inundation, Self-Determination, and Atoll Island States" (2016) 38 Human Rights Quarterly 1022.

William Thomas Worster "Relative International Legal Personality of Non-State Actors" (2016) 42(2) Brook J Int'l L 207.

Derek Wong "Sovereignty Sunk? The Position of Sinking States at International Law" (2013) 14 Melbourne Journal of International Law 1.

Katrina Miriam Wyman "Responses to Climate Migration" (2013) 37 Harv Env'l Law Rev 167.

Ineta Ziemele "The State Border between Latvia and Russia and the Doctrine of Continuity of the Republic of Latvia" (2009) 9 Baltic Y B Int'l L 95.

Gentian Zyberi "Self-Determination through the Lens of the International Court of Justice" (2009) NILR 429.

\section{Books and Chapters}

John Adams A Defence of the Constitutions of Government of the United States of America: Volume III (Piccadilly, 1794).

W Neil Adger, Jouni Paavola and Saleemul Huq "Towards Justice in Adaptation to Climate Change" in W Neil Adger and others Fairness in Adaptation to Climate Change (MIT Press, Cambridge MA, 2006) 1.

Spyridon Aktypis, Emannuel Decaux and Bronwen Leroy "Systemic integration between climate change and human rights at the United Nations?" in Ottavio Quirico and Mouloud Boumghar (eds) Climate Change and Human Rights: An international and comparative law perspective (Routledge, Abingdon, 2016) 221.

TRS Allen "Democracy, Legality, Proportionality", both in Grant Huscroft, Bradley W Miller and Grégoire Webber (eds) Proportionality and the Rule of Law: Rights, Justification, Reasoning (Cambridge University Press, Cambridge, 2014) 205.

Abdalla Ali El-Erian Condominium and Related Situations in International Law: with special reference to the dual administration of the Sudan and the legal problems arising out of it (Fouad I University Press, Cairo, 1951).

Rudy B Andeweg "Consociationalism" in Neil J Smelser and Paul B Bates (eds) International Encyclopedia of the Social and Behavioral Sciences, Volume 4 (2nd ed, Elsevier, 2001) 692.

Mariano J Anzar-Gómez "The Extinction of States" in Eva Rieter and Henri de Waele Evolving Principles of International Law: Studies in Honour of Karel C. Wellens (Martinus Nijhoff Publishers, Leiden, 2012) 25. 
Paige Arthur (ed) Identities in Transition: Challenges for Transitional Justice in Divided Societies (Cambridge University Press, Cambridge, 2011).

Fiona Barker National Identity and the Governance of Diversity: Old Politics, New Arrivals (Palgrave Macmillan, New York, 2015).

Isaiah Berlin Four Essays on Liberty (Oxford University Press, Oxford, 1969).

Isaiah Berlin "Two Concepts of Liberty" in Isaiah Berlin Four Essays on Liberty (Oxford University Press, Oxford, 1969).

GR Berridge and Lorna Lloyd The Palgrave Macmillan Dictionary of Diplomacy (3rd ed, online, Macmillan Publishers, London).

RS Bhalla "The Right of Self-Determination in International Law" in William Twining (ed) Issues of Self-Determination (Aberdeen University Press, Aberdeen, 1991).

Rachel Eden Black "Barbé-Marbois, François, Marquis de" in Junius P Rodriguez (ed) The Louisiana Purchase: A Historical and Geographic Encyclopedia (ABCClio, Santa Barbara, 2002) 24.

Richard Black, Dominic Kniveton and Kerstin Schmidt-Verkerk "Migration and Climate Change: Toward an Integrated Assessment of Sensitivity" in Thomas Faist and Jeanette Schade (eds) Disentangling Migration and Climate Change: Methodologies, Political Discourses and Human Rights (Springer, Heidelberg, 2013) 29.

Maxine A Burkett "The Nation Ex-Situ" in Michael B Gerrard and Gregory E Wannier (eds) Threatened Island Nations: Legal Implications of Rising Seas and a Changing Climate (Cambridge University Press, Cambridge, 2013) 89.

Petra Butler and Caroline Morris (eds) Small States in a Legal World (Springer, Heidelberg, 2017).

John Campbell "Climate Change and Population Movement in Pacific Island Countries" in Bruce Burson (ed) Climate Change and Migration: South Pacific Perspectives (Institute of Policy Studies, Wellington, 2010) 29.

Alejandra Torres Camprubí Statehood Under Water: Challenges of Sea-Level Rise to the Continuity of Pacific Island States (Brill Nijhoff, Leiden, 2016).

Antonio Cassese "The International Court of Justice and the right of peoples to SelfDetermination" in Vaughan Lowe and Malgosia Fitzgerald (eds) Fifty Years of the International Court of Justice: Essays in Honour of Sir Robert Jennings (Cambridge University Press, Cambridge, 1996) 351.

Antonio Cassese Self-Determination of Peoples: A Legal Reappraisal (Cambridge University Press, Cambridge, 1995).

Dhrishna Charan, Manpreet Kaur and Priyatma Singh "Customary Land and Climate Change Induced Relocation-A Case Study of Vunidogoloa Village, Vanua Levu, Fiji" in Walter Leal Filho (ed) Climate Change Adaptation in Pacific Countries: Fostering Resilience and Improving Quality of Life (Springer, Heidelberg, 2017) 19.

Ioana Cismas Religious Actors in International Law (Oxford University Press, Oxford, 2014). 
Alan Collins Contemporary Security Studies (4th ed, Oxford University Press, Oxford).

Alberto Costi and Nathan Ross "The Ongoing Legal Status of Low-Lying States in the Climate-Changed Future" in Petra Butler and Caroline Morris (eds) Small States in a Legal World (Springer, Heidelberg, 2017) 101.

James Crawford Brownlie's Principles of Public International Law (8th ed, Oxford University Press Oxford, 2012).

James Crawford The Creation of States in International Law (2nd ed, Oxford University Press, Oxford, 2006).

James Crawford (ed) The Rights of Peoples (Clarendon Press, Oxford, 1988) 159.

James Crawford "The Rights of Peoples: Some Conclusions" in James Crawford (ed) The Rights of Peoples (Clarendon Press, Oxford, 1988) 159.

James Crawford "State" in Rüdiger Wolfrum (ed) The Max Planck Encyclopedia of Public International Law (Oxford University Press, Oxford, 2012) 475.

Katja Creutz "Law versus Codes of Conduct: Between Convergence and Conflict" in Jan Klabbers and Touko Piiparinen (eds) Normative Pluralism and International Law: Exploring Global Governance (Cambridge University Press, Cambridge, 2013) 166.

Catherine Dauvergne Making People Illegal: What Globalization Means for Migration and Law (Cambridge University Press, Cambridge, 2008).

Katherine Del Mar "The myth of remedial secession" in Duncan French (ed) Statehood and Self-Determination: Reconciling Tradition and Modernity in International Law (Cambridge University Press, Cambridge, 2013) 79.

Martin Dixon, Robert McCorquodale and Sarah Williams Cases \& Materials on International Law (5th ed, Oxford University Press, Oxford, 2011).

Oliver Dörr and Kirsten Schmalenbach "Article 63. Fundamental change of circumstances" in Oliver Dörr and Kirsten Schmalenbach (eds) Vienna Convention on the Law of Treaties: A Commentary (Springer, Heidelberg, 2012) 1067.

Oliver Dörr and Kirsten Schmalenbach (eds) Vienna Convention on the Law of Treaties: A Commentary (Springer, Heidelberg, 2012) 1067.

Shaunnagh Dorsett and Shaun McVeigh "Section 223 and the shape of native title: The limits of jurisdictional thinking" in Lisa Ford and Tim Rowse (eds) Between Indigenous and Settler Governance (Routledge, Abingdon, 2013) 162.

John Duggard and David Raič "The role of recognition in the law and practice of statehood" in Marcelo G Kohen (ed) Secession: International Law Perspectives (Cambridge University Press, Cambridge 2006) 94.

Patrick Dumberry The Formation and Identification of Rules of Customary International Law in International Investment Law (Cambridge University Press, Cambridge, 2016). 
Alan Dupont and Graeme Pearman Heating Up the Planet: Climate Change and Security (2006).

Mason Durie Te Mana, Te Kawanatanga: The Politics of Māori Self-Determination (Oxford University Press, Oxford, 1998).

Jorrie C Duursma Fragmentation and the International Relations of Micro-States: Self-Determination and Statehood (Cambridge University Press, Cambridge, 1996).

Eugen Ehrlich "Judicial Freedom of Decision: Its Principles and Objects" in Joseph H Drake and others (eds) Modern Legal Philosophy Series: Vol. IX: Science of Legal Method: Select Essays by Various Authors (The Boston Book Company, Boston, 1917) 47.

Asbjørn Eide, Catarina Krause and Allan Rosas (eds) Economic, Social and Cultural Rights (2nd revised ed, Martinus Nijhoff Publishers, Dordrecht, 2001).

Thomas Faist and Jeanette Schade (eds) Disentangling Migration and Climate Change: Methodologies, Political Discourses and Human Rights (Springer, Heidelberg, 2013).

Ulrich Fastenrath and others (eds) From Bilateralism to Community Interest: Essays in Honour of Judge Bruno Simma (Oxford University Press, Oxford, 2011) 1278.

Walter Leal Filho (ed) Climate Change Adaptation in Pacific Countries: Fostering Resilience and Improving Quality of Life (Springer, Heidelberg, 2017).

Michael Flemming Auschwitz, the Allies and Censorship of the Holocaust (Cambridge University Press, Cambridge 2014).

Lisa Ford and Tim Rowse (eds) Between Indigenous and Settler Governance (Routledge, Abingdon, 2013).

Michael Freeman and Ross Harrison (eds) Law and Philosophy (Oxford University Press, Oxford, 2007).

Duncan French (ed) Statehood and Self-Determination: Reconciling Tradition and Modernity in International Law (Cambridge University Press, Cambridge, 2013).

Francine Friedman Bosnia and Herzegovina: A polity on the brink (Routledge, London, 2004).

Frances Galgano (ed) The Environment-Conflict Nexus: Climate Change and the Emergent National Security Landscape (Springer, Cham, CH, 2019) 1.

Francis A Galgano "The Environment-Conflict Nexus" in Frances Galgano (ed) The Environment-Conflict Nexus: Climate Change and the Emergent National Security Landscape (Springer, Cham, CH, 2019) 1.

Richard Gardiner Treaty Interpretation (2nd ed, Oxford University Press, Oxford, 2015).

Bryan A Garner (ed) Black's Law Dictionary (10th ed, Thomson Reuters, St Paul MN, 2009). 
Deon Geldenhuys Contested States in World Politics (Palgrave Macmillan, Basingstoke (UK), 2009).

Michael B Gerrard and Gregory E Wannier (eds) Threatened Island Nations: Legal Implications of Rising Seas and a Changing Climate (Cambridge University Press, Cambridge, 2013).

Dalila Gharbaoui and Julia Blocher "The Reason Land Matters: Relocation as Adaptation to Climate Change in Fiji Islands" in Andrea Milan and others (eds) Migration, Risk Management and Climate Change: Evidence and Policy Responses (Springer, Heidelberg, 2016) 149.

Thomas Giegerich "Article 62: Fundamental Change of Circumstances" in Oliver Dörr and Kirsten Schmalenbach (eds) Vienna Convention on the Law of Treaties: A Commentary (Springer, Heidelberg, 2012) 1143.

Chiara Giorgetti A Principled Approach to State Failure: International Community Actions in Emergency Situations (Martinus Nijhoff, Leiden, 2010).

Michał Gondek The Reach of Human Rights in a Globalising World: Extraterritorial Application of Human Rights Treaties (Intersentia, Mortsel, Belgium, 2009).

John P Grant and J Craig Barker Encyclopaedic Dictionary of International Law (3rd ed, Oxford University Press, Oxford, 2009).

Montserrat Guibernau Nations without States: Political Communities in a Global Age (Polity Press, Cambridge, 1999).

Hurst Hannum Autonomy, Sovereignty, and Self-Determination: The Accommodation of Conflicting Rights (University of Pennsylvania Press, Philadelphia, 1990).

Hurst Hannum "Self-Determination in the Post-Colonial Era" in Donald Clark and Robert Williamson (eds) Self-Determination: International Perspectives (Macmillan Press, Basingstoke, UK 1995) 12.

Hurst Hannum "Self-Determination in the Twenty-First Century" in Hurst Hannum and Eileen F Babbitt (eds) Negotiating Self-Determination (Lexington Books, Lanham, 2006) 61.

Hurst Hannum and Eileen F Babbitt (eds) Negotiating Self-Determination (Lexington Books, Lanham, 2006).

Andrew Halpin Rights \& Law - Analysis \& Theory (Hart Publishing, Oxford, 1997).

Ross Harrison "The Moral is: States Make Law" in Michael Freeman and Ross Harrison (eds) Law and Philosophy (Oxford University Press, Oxford, 2007) 159.

Rosalyn Higgins Problems \& Process: International Law and How We Use It (Oxford University Press, Oxford, 1994, reprinted 2010).

David Horton (ed) The Encyclopaedia of Aboriginal Australia (Aboriginal Studies Press, Canberra, 1994).

Grant Huscroft, Bradley W Miller and Grégoire Webber (eds) Proportionality and the Rule of Law: Rights, Justification, Reasoning (Cambridge University Press, Cambridge, 2014) 205. 
Nina HB Jørgensen "Elementary Considerations of Humanity" in Nina HB Jørgensen (ed) The Responsibility of States for International Crimes (Oxford University Press, Oxford, 2000) 123.

Sarah Joseph and Melissa Castan The International Covenant on Civil and Political Rights: Cases, Materials, and Commentary (3rd ed, Oxford University Press, Oxford, 2013).

Kelihiano Kalolo "Tokelau" in Stephen Levine (ed) Pacific Ways: Government and Politics in the Pacific Islands (2nd ed, Victoria University Press, Wellington, 2016) 325 .

John Kincaid and G Alan Tarr (eds) Constitutional Origins, Structure, and Change in Federal Countries (McGill-Queen's University Press, Montreal and Kingston, 2005).

Jan Klabbers International Law (Cambridge University Press, Cambridge, 2013).

Jan Klabbers and Touko Piiparinen Normative Pluralism and International Law: Exploring Global Governance (Cambridge University Press, Cambridge, 2013).

Karen Knop Diversity and Self-Determination in International Law (Cambridge University Press, Cambridge, 2002).

Marcelo G Kohen (ed) Secession: International Law Perspectives (Cambridge University Press, Cambridge 2006).

Harold Hongju Koh "Foreward: America's Conscience in International Law" in Michael P Scharf and Paul R Williams (eds) Shaping Foreign Policy in Times of Crisis: The Role of International Law and the State Department Legal Advisor (Cambridge University Press, New York, 2010) xi.

Gerard Kreijen State Failure, Sovereignty and Effectiveness (Martinus Nijhoff Publishers, Leiden, 2004).

Will Kymlicka "Transitional Justice, Federalism, and the Accommodation of Minority Nationalism" in Paige Arthur (ed) Identities in Transition: Challenges for Transitional Justice in Divided Societies (Cambridge University Press, Cambridge, 2011) 303.

Marc Lanteigne "Vanuatu" in Stephen Levine (ed) Pacific Ways: Government and Politics in the Pacific Islands (2nd ed, Victoria University Press, Wellington, 2016) 361 .

Hersch Lauterpacht, Recognition in International Law (Cambridge University Press, 1948).

Jonathan Law and Elizabeth A Martin (eds) A Dictionary of Law (6th ed, Oxford University Press, Oxford).

Stephen Levine (ed) Pacific Ways: Government and Politics in the Pacific Islands (2nd ed, Victoria University Press, Wellington, 2016).

Ulla Liukkunen "Lex Mercatoria in International Arbitration" in Jan Klabbers and Touko Piiparinen (eds) Normative Pluralism and International Law: Exploring Global Governance (Cambridge University Press, Cambridge, 2013) 166. 
Vaughan Lowe and Malgosia Fitzgerald Fifty Years of the International Court of Justice: Essays in Honour of Sir Robert Jennings (Cambridge University Press, Cambridge, 1996).

Martin Luterán "The Lost Meaning of Proportionality" in Grant Huscroft, Bradley W Miller and Grégoire Webber (eds) Proportionality and the Rule of Law: Rights, Justification, Reasoning (Cambridge University Press, Cambridge, 2014) 21.

Lauri Mälksoo Russian Approaches to International Law (Oxford University Press, Oxford, 2015).

William Manger "The Seventh International Conference of American States" (1934) 4 Bulletin of the Pan American Union 271.

Ian Martin Self-Determination in East Timor: The United Nations, the Ballot, and International Intervention (Lynne Rienner Publishers, Boulder CO, 2001).

Benoît Mayer and Christel Cournil "Climate change, migration and human rights" in Ottavio Quirico and Mouloud Boumghar (eds) Climate Change and Human Rights: An international and comparative law perspective (Routledge, Abingdon, 2016) 173.

Jane McAdam Climate Change, Forced Migration, and International Law (Oxford University Press, Oxford, 2012).

Edward McWhinney Self-Determination of Peoples and Plural-Ethnic States in Contemporary International Law: Failed States, Nation-building and the Alternative, Federal Option (Martinus Nijhoff, Leiden, 2007).

Rubya Mehdi "Law versus Religion: State Law and Religious Norms" in Jan Klabbers and Touko Piiparinen (eds) Normative Pluralism and International Law: Exploring Global Governance (Cambridge University Press, Cambridge, 2013) 284.

Andrea Milan and others (eds) Migration, Risk Management and Climate Change: Evidence and Policy Responses (Springer, Heidelberg, 2016).

Cameron Moore "Waterworld: Climate change, Statehood and the right to selfdetermination" in Ottavio Quirico and Mouloud Boumghar (eds) Climate Change and Human Rights: An international and comparative law perspective (Routledge, Abingdon, 2016) 104.

John Bassett Moore Digest of International Law: Volume 1 (U.S. Government Printing Office, 1906).

James Nickel "Human Rights" in Edward N Zolta (eds) The Stanford Encyclopedia of Philosophy (online ed, Standford CA, 8 November 2014).

Cathal J Nolan The Greenwood Encyclopedia of International Relations (Greenwood Publishing, Westport CT, USA, 2002).

Manfred Nowak U.N. Covenant on Civil and Political Rights: CCPR Commentary (2nd revised ed, N. P. Engel, Kehl, Germany).

DP O'Connell "The Condominium of the New Hebrides" in Humphrey Waldock and RY Jennings (eds) British Yearbook of International Law 1968-69 (Oxford University Press, London, 1970) 71. 
Lassa Oppenheim International Law: A Treatise: Volume I: Peace (Longmans, Green and Co, London, 1905), § 290, 344.

Alexander Orakhelashvili Peremptory Norms in International Law (Oxford University Press, Oxford, 2006).

Matthew SR Palmer The Treaty of Waitangi in New Zealand's Law and Constitution (Victoria University Press, Wellington, 2008).

Michla Pomerance Self-Determination in Law and Practice: The New Doctrine in the United Nations (Martinus Nijhoff, the Hague, 1982).

Ottavio Quirico and Mouloud Boumghar (eds) Climate Change and Human Rights: An international and comparative law perspective (Routledge, Abingdon, 2016) 221.

David Raič Statehood and the Law of Self-Determination (Kluwer Law International, The Hague, 2002).

Ernest Renan "What is a Nation? (Qu'est-ce Qu-une Nation?, 1882" in MFN Giglioli (editor and translator) Ernest Renan: What is a Nation? and Other Political Writings (Columbia University Press, New York 2018) 247.

Eva Rieter and Henri de Waele Evolving Principles of International Law: Studies in Honour of Karel C. Wellens (Martinus Nijhoff Publishers, Leiden, 2012).

Geoffrey Robertson The Case of the Pope: Vatican Accountability for Human Rights Abuse (Penguin Books, London, 2010).

Davis R Robinson "The Reagan Administration (1981-1985)" in Michael P Scharf and Paul R Williams (eds) Shaping Foreign Policy in Times of Crisis: The Role of International Law and the State Department Legal Advisor (Cambridge University Press, New York, 2010) 55.

Junius P Rodriguez (ed) The Louisiana Purchase: A Historical and Geographic Encyclopedia (ABC-Clio, Santa Barbara, 2002).

Allan Rosas "The Right of Self-Determination" in Asbjørn Eide, Catarina Krause and Allan Rosas (eds) Economic, Social and Cultural Rights (2nd revised ed, Martinus Nijhoff Publishers, Dordrecht, 2001) 111.

Michal Rozynek "Nationhood and its Critics" in Michal Rozynek (ed) A Philosophy of Nationhood and the Modern Self (Palgrave MacMillan, New York, 2017).

Michal Rozynek (ed) A Philosophy of Nationhood and the Modern Self (Palgrave MacMillan, New York, 2017).

Ruth Rubio-Marin, Claudia Paz y Paz Bailey and Julie Guillerot "Indigenous Peoples and Claims for Reparation: Tentative Steps in Peru and Guatemala" in Paige Arthur (ed) Identities in Transition: Challenges for Transitional Justice in Divided Societies (Cambridge University Press, Cambridge, 2011) 17.

Damon Salesa Island Time: New Zealand's Pacific Futures (Bridget Williams Books, Wellington, 2017). 
Michael P Scharf and Paul R Williams (eds) Shaping Foreign Policy in Times of Crisis: The Role of International Law and the State Department Legal Advisor (Cambridge University Press, New York, 2010).

Kirsten Schmalenbach "Preamble" in Oliver Dörr and Kirsten Schmalenbach (eds) Vienna Convention on the Law of Treaties: A Commentary (Springer, Heidelberg, 2012) 9.

Nicolas Schmitt "Swiss Confederation" in John Kincaid and G Alan Tarr (eds) Constitutional Origins, Structure, and Change in Federal Countries (McGillQueen's University Press, Montreal and Kingston, 2005) 348.

Nico Schrijver "The Impact of Climate Change: Challenges for International Law" in Ulrich Fastenrath and others (eds) From Bilateralism to Community Interest: Essays in Honour of Judge Bruno Simma (Oxford University Press, Oxford, 2011) 1278 .

James Brown Scott "The Seventh Conference of American States" (1934) 28(2) The AJIL 219.

Roger Scruton A Dictionary of Political Thought (Pan Books, London, 1983).

Malcolm N Shaw International Law (7th ed, Cambridge University Press, Cambridge, 2014).

Malcolm N Shaw "Self-Determination, Uti Possidetis and Boundary Disputes in Africa" in Chia-Jui Cheng (ed) A New International Legal Order: In Commemoration of the Tenth Anniversary of the Xiamen Academy of International Law (Koninklijke Brill, Leiden, 2016) 99.

IA Shearer Starke's International Law (11th ed, Butterworths, London, 1994).

W Phillips Shively Power \& Choice: An Introduction to Political Science (Rowman \& Littlefield, Lanham, Maryland, US, 2019).

Neil J Smelser and Paul B Bates (eds) International Encyclopedia of the Social and Behavioral Sciences, Volume 4 (2nd ed, Elsevier, 2001).

Catherine Soanes and Angus Stevenson (eds) Concise Oxford English Dictionary (11th ed, Oxford University Press, Oxford).

David Stanley Moon Handbooks: South Pacific (8th ed, Avalon Travel Publishing, Berkeley CA, 1999).

John Stewart Bowmen Colombia Chronologies of Asian History and Culture (Columbia University Press, New York City, 2000).

Jenny Grote Stoutenburg "When Do States Disappear? Thresholds for Effective Statehood and the Continued Recognition of 'Deterritorialized Island States" in Michael B Gerrard and Gregory E Wannier (eds) Threatened Island Nations: Legal Implications of Rising Seas and a Changing Climate (Cambridge University Press, Cambridge, 2013) 57.

James Summers Peoples and International Law: How Nationalism and SelfDetermination Shape a Contemporary Law of Nations (Martinus Nijhoff, Leiden, 2007). 
A Rigo Sureda The Evolution of the Right of Self-Determination: A study of United Nations Practice (A W Sijthoff, Leiden, 1973).

Nakibae Tabokai "The Maneaba System" in Howard Van Trease (ed) Atoll Politics: The Republic of Kiribati (Macmillan Brown Centre for Pacific Studies, University of Canterbury and Institute for Pacific Studies, University of the South Pacific, Christchurch and Suva, 1993) 23.

Salote Talagi "Niue" in Stephen Levine (ed) Pacific Ways: Government and Politics in the Pacific Islands (2nd ed, Victoria University Press, Wellington, 216) 188.

Stefan Talmon Recognition of Governments in International Law: With Particular Reference to Governments in Exile (Oxford University Press, Oxford, 1998).

Alaima Talu and others Kiribati: Aspects of History (University of the South Pacific and Ministry of Education Kiribati, 1979).

Daniel Thürer and Thomas Burri "Self-Determination" in Rüdiger Wolfrum (ed) The Max Planck Encyclopedia of Public International Law (Oxford University Press, Oxford, 2013) 113.

Desmond Tutu "We do not need climate change apartheid in adaptation" in Kevin Watkins and others Human Development Report 2007/2008: Fighting Climate Change: Human solidarity in a divided world (Palgrave Macmillan, New York, for the United Nations Development Programme, New York) 166.

William Twining (ed) Issues of Self-Determination (Aberdeen University Press, Aberdeen, 1991).

Howard Van Trease Atoll Politics: The Republic of Kiribati (Macmillan Brown Centre for Pacific Studies University of Canterbury and Institute of Pacific Studies University of the South Pacific, 1993).

Howard Van Trease "From Colony to Independence" in Howard Van Trease (ed) Atoll Politics: The Republic of Kiribati (Macmillan Brown Centre for Pacific Studies University of Canterbury and Institute of Pacific Studies University of the South Pacific, 1993) 3.

Humphrey Waldock and RY Jennings (eds) British Yearbook of International Law 1968-69 (Oxford University Press, London, 1970).

Kevin Watkins and others Human Development Report 2007/2008: Fighting Climate Change: Human solidarity in a divided world (Palgrave Macmillan, New York, for the United Nations Development Programme, New York).

Phillipa Webb "Cook Islands" in Stephen Levine (ed) Pacific Ways: Government and Politics in the Pacific Islands (2nd ed, Victoria University Press, Wellington, 216) 40.

Marc Weller and Barbara Metzger (eds) Settling Self-Determination Disputes: Complex Power-Sharing in Theory and Practice (Martinus Nijhoff, Leiden, 2008).

Pnina Werbner Imagined Diasporas Among Manchester Muslims: The Public Performance of Pakistani Transnational Identity Politics (James Currey, Oxford, 2002). 
Donald Clark and Robert Williamson (eds) Self-Determination: International Perspectives (Macmillan Press, Basingstoke, UK 1995).

Rüdiger Wolfrum (ed) The Max Planck Encyclopedia of Public International Law (Oxford University Press, Oxford, 2013).

Lilian Yamamoto and Miguel Esteban Atoll Island States and International Law: Climate Change Displacement and Sovereignty (Springer, Heidelberg, 2014).

Farhana Yamin and Joanna Depledge The International Climate Change Regime: A Guide to Rules, Institutions and Procedures (Cambridge University Press, Cambridge, 2004).

John Yoo Point of Attack: Preventative War, International Law, and Global Warfare (Oxford University Press, Oxford, 2014).

Matthew Zagor "Elementary considerations of humanity" in Karine Bannelier, Theodore Christakis and Sarah Heathcote (eds) The ICJ and the Evolution of International Law: The enduring impact of the Corfu Channel case (Routledge, London, 2012) 264.

Ineta Ziemele State Continuity and Nationality: The Baltic States and Russia: Past, Present and Future as Defined by International Law (Martinus Nijhoff Publishers, Leiden, 2005).

Edward N Zolta The Stanford Encyclopedia of Philosophy (online ed, Standford CA, 8 November 2014).

D. State and Non-State Organisations' and Persons' Reports, Online Resources, Media Releases, and Speeches

ABC News "Pacific Islanders reject 'climate refugee' status, want to 'migrate with dignity', SIDS conference hears" (6 September 2014) <www.abc.net.au>.

Farida Abubakari "Why Migration is a Legitimate Form of Adaptation to Climate Change in Ghana" (31 October 2015) Modern Ghana <www.modernghana.com>.

Al Jazeera "Key facts about the war in Yemen" (26 March 2018) <www.aljazeera.com>.

Mayesha Alam, Rukmani Bhatia and Briana Mawby Women and Climate Change: Impact and Agency in Human Rights, Security, and Economic Development (Georgetown Institute for Women, Peace and Security, 2015).

Alliance of Small Island States <www.aosis.org>.

American Law Institute U.S. Restatement of the Law, Third, Foreign Relations Law of the United States, Vol. 1 [Third Restatement of the Law].

Tony Angelo and Talei Pasikale Tokelau: A History of Government: The constitutional history and legal development of Tokelau (Council for the Ongoing Government of Tokelau, 2008). 
Anonymous "Briefing: Donald Trump and the World: Present at the Destruction" The Economist 427(9095) (9 June 2018) 21.

ASPLS Standards of Practice Manual (4th ed, Alaska Society of Professional Land Surveyors, 2013).

Frank Bainimarama, Prime Minister of Fiji and incoming President of the UN Climate Change Conference in Bonn in November (COP23) "Pacific Islands Need to Lead Global Climate Action Agenda" (Pacific Climate Partnership Event, Grand Pacific Hotel in Suva, Fiji, 3 July 2017).

Jon Barnett and Michael Webber "Accommodating Migration to Promote Adaptation to Climate Change: Background Paper to the 2010 World Development Report" (World Bank, Policy Research Working Paper 5270, April 2010).

BBC "Maldives Profile: Timeline" <www.bbc.com>.

BBC "Yemen Crisis: Why is There a War?" (18 December 2018) <www.bbc.com>.

Julie Beck "How Uncertainty Fuels Anxiety" The Atlantic (online ed, Washington DC, 18 March 2015).

The Borgen Project "Hunger in the Maldives" (26 April 2015) <borgenproject.org>.

Büsingen am Hochrhein "Local Portrait" <www.buesingen.de>.

Büsingen am Hochrhein "State Treaty: Germany - Switzerland via Büsingen" <www.buesingen.de>.

Cabinet Office Circular "Pacific climate change-related displacement and migration: a New Zealand action plan" (May 2018, CAB-18-MIN-0218) [CAB-18-MIN0218].

John R Campbell, Michael Goldsmith and Kanyathu Koshy Community Relocation as an Option for Adaptation to the Effects of Climate Change and Climate Vulnerability in Pacific Island Countries (PICs) (Asia-Pacific Network for Global Change Research. 2005).

Francesco Capotorti Human Rights Study Series 5: Study on the Rights of Persons Belonging to Ethnic, Religious and Linguistic Minorities (United Nations, New York, 1991).

Aengus Carroll and Lucas Ramón Mendos "State-Sponsored Homophobia: A World Survey of Sexual Orientation Laws: Criminalisation, Protection and Recognition" (12th ed, ILGA - the International Lesbian, Gay, Bisexual, Trans and Intersex Association, Geneva, May 2017).

Central Intelligence Agency "Australia-Oceania: Marshall Islands" The World Factbook <www.cia.gov>.

Central Intelligence Agency "Kosovo" The World Factbook <www.cia.gov>.

Central Intelligence Agency "The Marshall Islands" The World Factbook $<w w w . c i a . g o v>$.

Central Intelligence Agency "South Asia: Maldives" The World Factbook <www.cia.gov>. 
Michael M Cernea "Impoverishment Risks, Risk Management, and Reconstruction: A Model of Population Displacement and Resettlement" (Keynote Paper presented to the UN Symposium on Hydropower and Sustainable Development, Beijing, October 2000).

Michael M Cernea and Chris McDowell (eds) Risks and Reconstruction: Experiences of Resettlers and Refugees (The World Bank, Washington DC, 2000).

CHS Alliance Core Humanitarian Standard on Quality and Accountability (CHS Alliance, Groupe URD and the Sphere Project, 2014).

The Climate and Security Advisory Group Briefing Book for a New Administration: Recommended Policies and Practices for Addressing the Security Risks of a Changing Climate (Washington DC, 14 September 2016).

Commonwealth of Australia National Climate Resilience and Adaptation Strategy 2015 (2015).

Community Law Centres o Aotearoa "Choosing the right legal structure for your group" Community Law <www.communitylaw.org.nz>.

Companies Office (NZ) "What is an incorporated society?" <www.societies.govt.nz>.

Companies Office (NZ) "What are the advantages of becoming an incorporated society?" <www.societies.govt.nz>.

Stephen Cornell Indigenous Peoples, Poverty and Self-Determination in Australia, New Zealand, Canada and the United States (Native Nations Institute for Leadership, Management, and Policy, Tuscan, AZ, JOPNA No. 2006-02, 2006).

Richard Curtain and others Pacific Possible: Labour mobility: the ten billion dollar prize (World Bank and Australian National University, July 2016).

Coral Davenport and Campbell Robertson "Resettling the First American 'Climate Refugees'" New York Times (online ed, New York, 3 May 2016).

Paul Day "Spain prosecutor seeks long jail terms for Catalan pro-independence leaders" (2 November 2018) Reuters <www.reuters.com>.

Angie Dazé "Why Gender Matters in Climate Change Adaptation" (6 June 2019) International Institute for Sustainable Development <www.iisd.org>.

Department for Environment, Food and Rural Affairs (UK) The National Adaptation Programme: Making the country resilient to a changing climate (July 2013).

Department for Environment, Food and Rural Affairs (UK) The National Adaptation Programme Report: Analytical Index: Economics of the National Adaptation Programme (July 2013).

Department of Environment and Energy (AU) National Climate Resilience and Adaptation Strategy 2015 (2015).

Department of Foreign Affairs and Trade (AU) "Aid Investment Plan Kiribati: 2015/16-2018/19" (30 September 2015).

Department of Foreign Affairs and Trade (AU) "Annual Report 2017-18". 
Department of Foreign Affairs and Trade (AU) "Environment and Climate Change in Tuvalu" <www.dfat.gov.au>.

Department of State (US) "HR Fact Sheet: Facts About Our Most Valuable Asset Our People: As at 12/31/2018".

Department of State (US) "U.S. Relations With Somalia" <www.state.gov>.

Displacement Solutions Climate Change, Displaced Persons and Housing, Land and Property Rights: Preliminary Strategies for Rights-Based Planning and Programming to Resolve Climate-Induced Displacement (Displacement Solutions, Geneva).

Michael Dodson, Aboriginal and Torres Strait Islander Social Justice Commissioner "Assimilation versus self-determination: no contest" (H.C. (Nugget) Coombs Northern Australia Inaugural Lecture, Darwin, 5 September 1996).

Alistair Doyle "Kiribati President Favors Buying Land Elsewhere As Islands Are Threatened By Rising Sea Levels" (22 September 2014) Huffington Post <www.huffingtonpost.com>.

Alan Duncan "British Indian Ocean Territory" (Foreign and Commonwealth Office, Written statement - HCWS1528, 30 April 2019) available at <www.parliament.uk>.

Andrew Ellis and others Voting from Abroad: The International IDEA Handbook (International Institute for Democracy and Electoral Assistance and the Federal Electoral Institute of Mexico, 2007).

James Ellsmoor and Zachary Rosen "Kiribati's land purchase in Fiji: does it make sense?" (11 January 2016) DevPolicy <www.devpolicy.org>.

Encyclopædia Britannica "Maldives" <www.britannica.com>.

Expert Group on Global Climate Obligations Oslo Principles on Global Climate Change Obligations (March 2015).

Mark Eyskens, Minister for Foreign Affairs (BE) (press release, 23 August 1991).

José Luis Ferreira "The effects of immigrants in the host country" (16 December 2016) Mapping Ignorance <mappingignorance.org>.

Jared Ferrie "Climate change and mass migration: a growing threat to global security" (19 January 2017) IRIN: The Inside Story on Emergencies <www.irinnews.org>.

Aled Dilwyn Fisher A Human Rights-Based Approach to the Environment and Climate Change (The Global Initiative for Economic, Social and Cultural Rights, Practitioner's Guide, 2014).

Max Fisher "Who is Venezuela's Legitimate President? A Messy Dispute, Explained" (4 February 2019) New York Times <www.nytimes.com>.

Melanie Fitzpatrick "What Accounts for the Varying Rates of Sea Level Rise in Different Locations?" (June 2013) Union of Concerned Scientists <www.ucsusa.org $>$. 
Joanna M Foster "Epic King Tides Offer Glimpse of Climate Change in Marshall Islands" (6 March 2014) ThinkProgress <www.thinkprogress.org>.

Laure Fourquet "This Catalan Town Has Already Broken From Spain, Physically at Least" The New York Times (online ed, New York, 24 October 2017).

Michael Fry "Danzig and the Beginnings of World War II" (28 August 2014) National Geographic <www.nationalgeographic.org>.

The Fund for Peace "Fragile States Index: Indicators" <www.fundforpeace.org>.

Laurie Goering "As climate change uproots communities, innovation can rescue culture" (15 November 2016) Reuters <www.reuters.com>.

Government of Tokelau "Summary of the Treaty of Free Association" <www.tokelau.org.nz>.

Emma Green "A Vatican Diplomat Has Been Recalled From the U.S. Following Child-Pornography Charges" (15 September 2017) The Atlantic $<w w w . t h e a t l a n t i c . c o m>$.

Joy Guillemot "Child Rights at Risk: the Case for Joint Action with Climate Change" UNICEF Office of Research-Innocenti <www.unicef-irc.org>.

Icelandic Human Rights Centre "The Human Rights Protection of Vulnerable Groups" <www.humanrights.is>.

Indigenous Land Corporation ILC Group Corporate Plan 2017-18: Strategy to 2021 (Australian Government).

International Bar Association Achieving Justice and Human Rights in an Era of Climate Disruption: Climate Change Justice and Human Rights Task Force Report (July 2014).

International Council on Human Rights Policy Climate Change and Human Rights: A Rough Guide (2008).

International Federation of the Red Cross and Red Crescent Societies "Working partners" <www.ifrc.org>.

Manipadma Jena "As climate threats drive migration, Indian women find opportunities" (18 October 2018) Reuters <www.reuters.com>.

Sam Jones "Crisis over Catalonia - an explainer" The Guardian (online ed, London, 4 November 2017).

Matthew Kahn, University of California, in Consolidated Reply: Query: Promoting Economic Migration as a Climate Change Adaptation Strategy. Experiences; Advice (submission by the Climate Change and Development (CCD) Community of the Pacific Solution Exchange to the Executive Committee of the Warsaw International Mechanism for Loss and Damage on internal and crossborder migration, displacement and other forms of human mobility, 16 May 2016).

Kaldor Centre Principles for Australian Refugee Policy (Andrew and Renata Kaldor Centre for International Refugee Law, University of New South Wales, 2019). 
Elaine Kelly "Migration is a solution to climate change, not a threat to security" (21 November 2013) The Conversation <www.theconversation.com>.

Ben King, Deputy-Secretary of Foreign Affairs and Trade (New Zealand) "New Zealand's place in a changing world" (University of Canterbury, New Zealand, 20 September 2018) available at <www.mfat.govt.nz>.

Land Information New Zealand "Map of the Continental Shelf Boundary" <www.linz.govt.nz>.

Charlene Lanyon "Forced displacement last option, says Tuvalu PM" Fiji Times (online ed, Suva, 13 December 2016).

Legal Information Institute, Cornell University Law School "Self Determination (International Law)" Wex Legal Dictionary <www.law.cornell.edu/wex>.

Jon Letman "Climate Change Is A 'Matter Of Life And Death' For The Marshall Islands" (4 November 2016) Honolulu Civil Beat <www.civilbeat.org>.

Amanda Little "What the Paris Climate Agreement means for Vulnerable Nations" The New Yorker (online ed, 15 December 2015).

H.E. Taneti Maamau "H.E sets the tone for his country in the face of Climate Change" (16 November 2017) Kiribati Updates <kiribatiupdates.com.ki>.

Māori Dictionary <www.maoridictionary.co.nz> .

Māori Land Court Te Kooti Whenua Māori "Māori Land Trusts \& Incorporations" <www.maorilandcourt.govt.nz>.

Submission of the Māori Land Court Judges to the Māori Affairs Select Committee on Te Ture Whenua Māori Amendment Bill 1999.

"Margaret Thatcher: A Life in Quotes" The Guardian (online ed, London, 8 April 2013).

Karl Mathiesen and Fiona Harvey "Climate coalition breaks cover in Paris to push for binding and ambitious deal" The Guardian (online ed, London, 8 December 2015).

Angus McDowall "Why Yemen is at war" (16 June 2018) Reuters <www.reuters.com>.

Silvia Merler "The economic effects of migration" (16 January 2016) Bruegel <bruegel.org>.

JJ Messner and others Fund for Peace 2018 Fragile States Index (Fund for Peace, Washington DC, 2018).

Andrea Milan, Robert Oakes and Jillian Campbell Tuvalu: Climate Change and Migration: Relationships Between Household Vulnerability, Human Mobility and Climate Change (Institute for Environment and Human Security, United Nations University, Report no. 18, November 2016).

Oliver Milman "UN drops plan to help move climate change affected people" The Guardian (online ed, London, 7 October 2015). 
Ministry for the Environment (NZ) New Zealand's Framework for Adapting to Climate Change (August 2014).

Ministry of Economy (FJ) Planned Relocation Guidelines: A framework to undertake climate change related relocation (Suva, 2018).

Ministry of Foreign Affairs (LI) Priorities of Liechtenstein Foreign Affairs (Government of the Principality of Liechtenstein, Vaduz).

Ministry of Foreign Affairs and International Cooperation (FJ) Fiji's Relocation Guideline (Draft) (18 October 2018).

Ministry of Foreign Affairs and Trade (NZ) "Aid partnership with Tokelau" <www.mfat.govt.nz>.

Ministry of Foreign Affairs and Trade (NZ) "New Zealand Aid Programme Strategic Plan 2015-19" (2015).

Ministry of Foreign Affairs and Trade (NZ) "Niue" <www.mfat.govt.nz>.

Ministry of Foreign Affairs and Trade (NZ) "Tokelau" <www.mfat.govt.nz>.

Ministry of Foreign Affairs and Trade (NZ) "UNGA73: Special Political and Decolonisation Committee (Fourth Committee): statement on the question of Tokelau delivered by New Zealand" (United Nations, New York, 12 October 2018), available at <www.mfat.govt.nz>.

Ministry of Social Development (NZ) Nga vaka o kāinga tapu: A Pacific Conceptual Framework to address family violence in New Zealand (March 2012).

Hassan Sheikh Mohamud, President of Somalia "Implementing Vision 2016: Inclusive Politics in Action" (High-Level Meeting on Somalia, United Nations, New York, 24 September 2016).

Phillip H Muller "National Communication regarding the Relationship Between Human Rights \& The Impacts of Climate Change" (Permanent Mission of the Republic of the Marshall Islands to the United Nations, submission to the United Nations Human Rights Council, 31 December 2008).

Nannetew "Three-Point Q and A with Hon Ralph Regenvanu, Minister of Foreign Affairs, International Cooperation and External Trade, Vanuatu at the UN Climate Conference" 11 December 2018) SPREP <www.sprep.org>.

The Nansen Initiative <www.nanseninitiative.org>.

The Nansen Initiative Agenda for the Protection of Cross-Border Displaced Persons in the Context of Disasters and Climate Change (December 2015) [Protection Agenda].

The Nansen Initiative Human Mobility, Natural Disasters and Climate Change in the Pacific: Summary of Conclusions: Nansen Initiative Pacific Regional Consultation: Rarotonga, Cook Islands, 21-24 May 2013 (The Nansen Initiative, Geneva, 2013).

National Bureau of Statistics (MV) "Statistical Release 1: Population and Households", "Table PP 5: Resident Population by Sex, Nationality and Locality 
(Administrative Islands), 2014" Ministry of National Planning and Infrastructure <www.statisticsmaldives.gov.mv>.

National Statistics Office (TV) "2015 Population and Housing Census: Volume 1: Management Report and Basic Tables" (Ministry of Finance and Economic Development, September 2016).

National Statistics Office (KI) Report on the Kiribati 2010 Census of Population and Housing: Vol 1 Basic Information and Tables (Ministry of Finance, August 2012).

National Statistics Office (KI) "2015 Population and Housing Census: Volume 1: Management Report and Basic Tables" (Ministry of Finance, September 2016).

Arthur Nelsen "Bloomberg demands seat at UN climate negotiating table for cities and states" (11 November 2017) Climate Home News <www.climatechangenews.com>.

New Zealand Geographic "Virtual Reality: Niue" <www.nzgeo.com>.

New Zealand Government "Treaty settlement documents" <www.govt.nz>

New Zealand Law Commission Review of the Law of Trusts: A Trusts Act for New Zealand (Report 130, August 2013).

New Zealand Law Commission Treaty of Waitangi Claims: Addressing the PostSettlement Phase (NZLC SP13, 2002).

Norwegian Refugee Council The Nansen Conference: Climate Change and Displacement in the 21st Century (Oslo, 5-7 June 2011) [The Nansen Principles].

Robert Oakes and others Climate Change and Migration in the Pacific: Links, attitudes and future scenarios in Nauru, Tuvalu, and Kiribati (United Nations University Institute for Environment and Human Security, fact sheet, 2017).

Office of the Historian (US) "Milestones: 1914-1920: Wilson's Fourteen Points, 1918" Department of State <history.state.gov>.

Office of the President of Kiribati "Relocation" Kiribati Climate Change <www.climate.gov.ki>.

Office of the President of Kiribati "President tells of greatest challenge" (press release, 26 September 2009).

Office of the President of Kiribati "Fiji Supports Kiribati On Sea Level Rise" (press release, 11 February 2014).

Anthony Oliver-Smith Resettlement Principles (submission by Kristina J Peterson of the Lowlander Center to the Executive Committee of the Warsaw International Mechanism for Loss and Damage on internal and cross-border migration, displacement and other forms of human mobility, 16 May 2016).

Order of Malta "1048 to the present day" <www.orderofmalta.int>.

Order of Malta "Bilateral Relations" <www.orderofmalta.int>. 
Order of Malta "The government seat of the Sovereign Order of Malta" <www.orderofmalta.int >.

Order of Malta "Multilateral Relations" <www.orderofmalta.int>.

Oxfam "A climate in crisis: How climate change is making drought and humanitarian disaster worse in East Africa" (press briefing, 27 April 2017, ref 01/2017).

Christopher Pala "Kiribati President Purchases 'Worthless' Resettlement Land as Precaution Against Rising Sea" (9 June 2014) Inter Press Service <www.ipsnews.net>.

Parliamentary Assembly of the Council of Europe Situation of the Baltic peoples PACE Res 872 (1987).

Winston Peters "Administrator of Tokelau announced" (press release, 15 December 2017).

Platform on Disaster Displacement <www.disasterdisplacement.org>.

Philip Puellella "Pope will have security, immunity by remaining in the Vatican" (16 February 2013) Reuters <www.reuters.com>.

Radio New Zealand "Fiji reiterates climate migration help to Kiribati" (14 July 2015) <www.radionz.co.nz>.

Radio New Zealand "Tuvalu looking at buying NZ and Aust land for displaced" (24 August 2015) <www.radionz.co.nz>.

Ursula Rakova Submission to the Executive Committee of the Warsaw International Mechanism for Loss \& Damage: Information on Internal Displacement \& Relocation owing to factors relating to Climate Change Impacts: Actual (not Potential) Challenges (Tulele Peisa Inc, 10 May 2016).

Ursula Rakova "Tulele Peisa Inc: Where are we?" (presentation to the workshop Readying the Wakas: New Zealand's Response to Climate Change-Induced Displacement in the Pacific, Wellington, October 2018).

Randeep Ramesh "Paradise almost lost: Maldives seek to buy a new homeland" The Guardian (online ed, London, 10 November 2008).

Alex Randall "Not the end for displacement at the Paris climate talks" (7 October 2015) Climate and Migration Coalition <www.climatemigration.org.uk〉.

Sachithanandam Sathananthan "External Self Determination, Internal DeColonisation and Conflict Prevention" (paper presented at the Seminar on Selfdetermination and Conflict Prevention Sponsored by Centre UNESCO de Catalunya and the UNESCO Etxea UNESCO Centre of the Basque Country Palais des Nations, Geneva, March 1999).

Samoa National Human Rights Institute State of Human Rights Report 2017 (Office of the Ombudsman, September 2018).

Michael Savage "Tony Blair: migrants should be forced to integrate more to combat far right" The Guardian (online ed, London) 21 April 2019.

Jess Shankleman "A Tiny Island Prepares the World for a Climate Refugee Crisis" (15 November 2017) Bloomberg <www.bloomberg.com>. 
Pita Sharples "Supporting the UN Declaration restores NZ's mana" (press release, 20 April 2010).

James Shaw "Global climate change agreement extended to Tokelau" (press release, 14 November 2017).

Debbie Singh "Regional meeting eyes Pacific climate migration and displacement" (7 December 2016) Asia Pacific Report <www.asiapacificreport.nz>.

Viraj Solanki "State of emergency ends, but the Maldives is still in crisis" (3 April 2018) International Institute for Strategic Studies <www.iiss.org>.

South China Morning Post "'Anything is better than the status quo': Guam eyes end to American colonial rule" (16 July 2017) <www.scmp.com>.

Sovereign Military Hospitaller Order of St John or Jerusalem of Rhodes and of Malta "A brief description of its sovereignty, diplomacy, government and history" (1 March 2018).

SPC "Tuvalu - Tuvalu Population and Housing Census 2012" (Secretariat of the Pacific Community, 14 July 2016) Pacific Data Library <pdl.spc.int>.

SPREP "Climate induced displacement a stark reality for Pacific islands" Secretariat of the Pacific Regional Environment Programme (11 November 2016) <www.sprep.org>.

Statistics New Zealand "2013 Census ethnic group profiles - Niuean" <www.stats.govt.nz>.

Statistics New Zealand "2013 Census QuickStats about culture and identity" (14 April 2014) <www.stats.govt.nz>

Philip Stephens "Sovereignty and self-determination collide in Catalonia" Financial Times (online ed, London, 5 October 2017).

Indira Stewart "Indigenous views crucial on climate change" (4 October 2018) Radio New Zealand <www.radionz.co.nz〉.

Stuff "Government considering experimental climate change visa" (1 November 2017) <www.stuff.co.nz>.

Submission of the Maldives to the Office of the UN High Commissioner for Human Rights under Human Rights Council Resolution 7/23 "Human Rights and Climate Change" (25 September 2008).

Aqela Susu "\$1.6m relocation plan for seven households" Fiji Times (Suva, online ed, 5 October 2016).

John D Sutter "You're Making This Island Disappear" (June 2015) CNN <www.cnn.com>.

Sarah Taylor "Fiji prepares for 'climate refugees'" (17 November 2017) EuroNews <www.euronews.com>.

Leah Te Whata "Labour Party promises to support Pacific climate change refugees" Māori Television (online ed, Auckland, 16 July 2017). 
Karen F Tilton "Alaska Native Claims Settlement Act (ANCSA)" in ASPLS Standards of Practice Manual (4th ed, Alaska Society of Professional Land Surveyors, 2013) Chapter 3.

Anote Tong "Climate Change Refugees: A Catastrophe of Our Own Creation" (20 June 2016) Medium <www.medium.com>.

Adam Tooze "Rising Tides Will Sink Global Order" (20 December 2018) Foreign Policy <foreignpolicy.com>.

Unitarian Universalist Association Concept Note: Intergenerational Spring Seminar Theme Panel (Unitarian Universalist Association United Nations Office, New York, 6 April 2018).

US Mission to Somalia "Arrival of U.S. Ambassador to Somalia Donald Y. Yamamoto" (press release, 15 November 2018).

Ropate Valemie "Climate Change" The Fiji Times (online ed, Suva, 22 March 2016).

Vanuatu National Disaster Management Office National Policy on Climate Change and Disaster-Induced Displacement (2018).

Vatican City State "Diplomatic Relations " <www.vatican.va>.

Vatican City State "Population" <www.vaticanstate.va>.

Vatican City State "State and Government" <www.vaticanstate.va>.

Roda Verheyen and Peter Roderick Beyond Adaptation: The legal duty to pay compensation for climate change damage (WWF-UK, November 2008).

Koko Warner, Alex de Sherbinin, Susana Adamo and Tricia Chai-Onn In Search of Shelter: Mapping the Effects of Climate Change on Human Migration and Displacement (CARE International, May 2009).

Caitlin E Werrell and Francesco Femia Climate Change as Threat Multiplier: Understanding the Broader Nature of the Risk (The Center for Climate \& Security, Briefer no. 25, 12 February 2015).

Wikipedia "Desert Island" <www.wikipedia.org>.

Wikipedia "List of Islands of Kiribati" <www.wikipedia.org>.

Wikipedia "Solander Islands" <www.wikipedia.org>.

Wikipedia "Uninhabited islands of Australia" <www.wikipedia.org>.

World Union of Jewish Students "The Jewish Internet - A Guru's View" <www.wujs.org.il>.

Rhodri C Williams Protecting Internally Displaced Persons: A Manual for Law and Policymakers (Brookings-Bern Project on Internal Displacement, Washington DC, October 2008)

Wilton Park Report: Navigating Pacific futures: climate change and resilience: Sunday 16 - Tuesday 18 December 2018 (report WP1631, March 2019). 
Fred M Zeder II "Understanding Free Association as a Form of Separate Sovereignty and Political Identity in the Case of Decolonization of Puerto Rico" Puerto Rico Herald <www.puertorico-herald.org >.

Zuleyka Zevallos "What is Otherness?" (14 October 2011) The Other Sociologist $<w w w . o t h e r s o c i o l o g i s t . c o m>$.

\section{E. Trust Deeds}

Deed of Settlement of Historical Claims: Hineuru and the Trustees of te Koppere o te Iwi o Hineuru Trust and the Crown (2015).

Raukawa Settlement Trust: Trust Deed (30 October 2013).

Tūhoe me te Uru Taumatua Rāua ko te Karauna / The Crown: Te Whakatauna o nā Tohe Raupatu Tawhito: Deed of Settlement of Historical Claims (4 Pipiri 2013, 4 April 2013).

\section{F. Dissertations}

James Allwood "How climate change displaces Pacific Island settlements and the public's perception of large scale migration" (MS Sc Thesis, University of Waikato, 2013).

Nani Suryani Haji Abu Bakar "Brunei's Political Developments Between 1966 and 1984: Challenges and Difficulties over its Security and Survival" (PhD thesis, University of Leeds, 2006).

Caroline Jenny McDonald "Decolonisation and Free Association: The Relationship of the Cook Islands and Niue with New Zealand" ( $\mathrm{PhD}$ dissertation, Victoria University of Wellington, 2018).

Ahmed Shaig "Settlement planning for natural hazard resilience in small island states: the population and development consolidation approach" (PhD thesis, James Cook University, 2008).

Susannah Willcox "Climate Change Inundation and Atoll Island States: Implications for Human Rights, Self-Determination and Statehood" ( $\mathrm{PhD}$ thesis, London School of Economics and Political Science, 2015). 